Aus dem Institut für Pflanzenpathologie und Pflanzenschutz der Georg-August Universität Göttingen

\title{
Untersuchungen zur Resistenz von Kartoffeln gegenüber Helminthosporium solani, dem Erreger des Silberschorfs, sowie dessen Übertragung von Mutter- auf Tochterknollen
}

\author{
Dissertation \\ zur Erlangung des Doktorgrades \\ der Fakultät für Agrarwissenschaften \\ der Georg-August-Universität Göttingen
}

vorgelegt von

Lili Hofmann

Geboren in Den Haag, Holland

Göttingen, im März 2005 
D7

1. Referentin/Referent: Prof. A. von Tiedemann

2. Korreferentin/Korreferent: Prof. P. Karlovsky

Tag der mündlichen Prüfung: 19. Mai 2005 


\section{Abschiedsworte an Pellka}

Jetzt schlägt Deine schlimmste Stunde, du Ungleichrunde, du Ausgekochte, du Zeitgeschälte, du Vielgequälte, du Gipfel meines Entzückens, Jetzt kommt der Moment des Zerdrückens, Mit der Gabel - sei stark! Ich will auch Butter und Quark

Oder Kümmel, auch Leberwurst in dich stampfen.

Mußt nicht gleich so ängstlich dampfen.

Ich möchte dich doch noch einmal erfreun.

Soll ich Schnittlauch über dich streun?

Oder ist dir nach Hering zumut?

Du bist ein rührend junges Blut.

Deshalb schmeckst du besonders gut.

Wenn das auch egoistisch klingt, So tröste dich damit, du wundervolle

Pellka, daß du eine Edelknolle

Warst, und daß dich ein Kenner verschlingt.

Ringelnatz, Joachim (1883-1934) 
Einleitung 1

Material und Methoden $\quad 5$

1 Verbrauchsmaterialien und Geräte 5

2 Chemikalien und Biochemikalien 6

3 Medien und Puffer $\quad 8$

4 Pilz- und Pflanzenmaterial $\quad 10$

5 Isolierung und Anzucht von Pilzmaterial 12

5.1 Isolierung von Helminthosporium solani von Kartoffelknollen und Anlegen einer Isolatesammlung $\quad 12$

5.2 Isolierung von $\boldsymbol{H}$. solani aus Bodenproben mit Bengal Rosa Agar 13

5.3 Flotationsverfahren zur Isolierung von $\boldsymbol{H}$. solani Konidien aus Bodenproben $\quad 14$

5.4 Wachstumstest von $H$. solani auf verschiedenen Medien $\quad 14$

5.5 Anzucht von $\boldsymbol{H}$. solani auf Agarplatten 15

5.6 Anzucht von Cladosporium spp. 16

6 Befallsbonituren an Kartoffelknollen $\quad 16$

7 Inokulumherstellung und Inokulationsmethoden 16

8 Feldversuche 17

9 Gewächshausversuche $\quad 19$

9.1 Rückstellprobe $\quad 19$

$\begin{array}{ll}9.2 \text { Screeningversuche } & 19\end{array}$

9.3 Split-root Test zur Überprüfung des Übertragungsweges

von $H$. solani

9.4 Rinnenversuch zur Überprüfung des Übertragungswegs von $H$. solani $\quad 21$

10 Klimakammerversuche zur Untersuchung der Befallsentwicklung im Lager (Boxentest) $\quad 23$

11 Bodensuppressivitätstests $\quad 23$

11.1 Bodensuppressivitätstest mit Kartoffelwasser 24

$\begin{array}{ll}\text { 11.2 Enzymatische Zuckeranalyse } & 24\end{array}$

12 Anzucht von Meristemkartoffeln 26

13 Vermessung der Periderm-Cortexdicke mit Hilfe der $\begin{array}{ll}\text { computerbasierten Bildanalyse } & 27\end{array}$

14 Überprüfung der Schalenbeschaffenheit mittels Wägetest 28 
15 Mikroskopische Untersuchungen

16 Analyse von Phytoalexinen mittels Dünnschichtchromatographie (DC), Bioassay und Hochdruckflüssigkeitschromatographie (HPLC) 29

16.1 Extraktion der Phytoalexine aus Kartoffelschalen 29

16.2 Auftrennung der Proben mittels DC 30

$\begin{array}{ll}16.3 \text { Bioassay } & 30\end{array}$

16.4 Analyse der Proben mittels HPLC 31

17 Untersuchung phenolischer Verbindungen in Kartoffelschalen 32

17.1 Aufbereitung des Schalenmaterials mit Thioglykolsäure und quantitative Analyse 32

17.2 Aufbereitung des Schalenmaterials mittels alkalischer Hydrolyse für die qualitative Analyse mit HPLC

17.3 Qualitative Analyse von Phenolcarbonsäuren bzw.

Aldehyden mit HPLC 34

18 Molekularbiologische Methoden $\quad 34$

18.1 Isolierung von $H$. solani DNA aus Sterilkulturen 34

18.2 Isolierung von $H$. solani DNA aus Pflanzenproben 34

18.3 Isolierung von $H$. solani DNA aus stärkehaltigen Knollenproben 35

$\begin{array}{ll}\text { 18.4 PCR } & 36\end{array}$

$\begin{array}{ll}\text { 18.5 Gelelektrophorese } & 37\end{array}$

19 Statistische Auswertung $\quad 37$

$\begin{array}{ll}\text { Ergebnisse } & 38\end{array}$

1 Isolierung und Anzucht von H. solani zur Herstellung des Inokulums 38

1.1 Isolierung von $\boldsymbol{H}$. solani von Knollen und Erstellung einer

$\begin{array}{ll}\text { Isolatebank } & 38\end{array}$

1.2 Isolierung von $\boldsymbol{H}$. solani aus Bodenproben mittels

$\begin{array}{ll}\text { Flotationsverfahren } & 38\end{array}$

1.3 Einsatz von Bengal Rosa zur Isolierung von $H$. solani aus Bodenproben

1.4 Wachstumsansprüche von $H$. solani in Flüssig - bzw. auf Agarmedium 41

2 Feldversuche $\quad 45$

3 Nachstellung der Feldversuche im Gewächshaus 69

4 Untersuchung der Resistenzfaktoren $\quad 75$ 
4.1 Strukturelle Abwehrmechanismen $\quad 75$

$\begin{array}{ll}\text { 4.1.1 Periderm-Cortexdicke } & 75\end{array}$

$\begin{array}{ll}\text { 4.1.2 Schalenbeschaffenheit } & 77\end{array}$

4.1.3 Mikroskopische Untersuchungen $\quad 78$

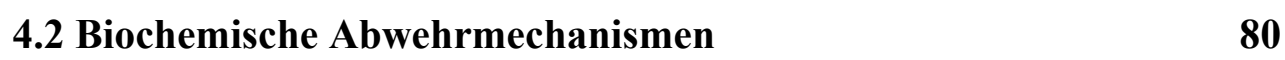

4.2.1 Dünnschichtchromatographie und Bioassay 80

$\begin{array}{lr}\text { 4.2.2 Phytoalexine } & 81\end{array}$

4.2.3 Quantitative Analyse phenolischer Verbindungen $\quad 81$

4.2.4 Qualitative Analyse phenolischer Verbindungen mittels HPLC

5 Übertragung von $H$. solani von Mutter- auf Tochterknollen 86

5.1 Passive Übertragung über das Bodenwasser 86

5.1.1 Split-root Test $\quad 86$

5.1.2 Rinnenversuche $\quad 86$

$\begin{array}{lr}\text { 5.1.3 Bodensuppresivitätstest } & 88\end{array}$

5.1.4 Bodensuppressivitätstest mit Kartoffelwasser und enzymatische Zuckeranalyse $\quad 89$

5.2 Untersuchung der Übertragung über Stolonen mittels PCR 93

Diskussion 99

1. Inokulumherstellung und Erstellung eines Standardsortiments 99

2. Resistenzfaktoren $\quad 105$

3. Übertragungswege und Lebenszyklus von $H$. solani 114

$\begin{array}{ll}\text { Zusammenfassung } & 118\end{array}$

$\begin{array}{lr}\text { Summary } & 120\end{array}$

$\begin{array}{lr}\text { Literatur } & 122\end{array}$ 


\section{Abkürzungsverzeichnis}

A

Abb.

ACE

A. dest.

ADP

ATP

BBA

bp

bzw.

$\mathrm{C}$

${ }^{\circ} \mathrm{C}$

ca.

$\mathrm{cm}$

CTAB

DC

DFRC

DNA

$\mathrm{E}$

EC

EDTA

G

$g$

g

$\circ$

$\mathrm{h}$

$\mathrm{HCl}$

$\mathrm{H}_{2} \mathrm{O}$

$\mathrm{hPa}$

HPLC

ITS

$\mathrm{kb}$

$\mathrm{kg}$

1

Lgs.

M
Adenin

Abbildung

Trichloressigsäure

destilliertes Wasser

Adenosin-5' -diphosphat

Adenosin-5'-triphosphat

Biologische Bundesanstalt

Basenpaare

Beziehungsweise

Cytosin

Grad Celsius

circa

Zentimeter

Cetyltrimethylammoniumbromid

Dünnschichtchromatographie

derivatization followed by reductive cleavage

Desoxyribonukleinsäure

Extinktion

Entwicklungsstadiums der Pflanzen im Feld

Ethylendiamintetraacetat

Guanin

Schwerefeldbeschleunigung der Erde

Gramm

Grad

Stunde

Salzsäure

Wasser

Hektopascal

Hochdruckflüssigkeitschromatographie

internal transcribed spacer

Kilobasen

Kilogramm

Liter

Lösung

Mol 


\begin{tabular}{|c|c|}
\hline $\mathrm{m}$ & Meter \\
\hline $\mathrm{mEx} / \mathrm{mg} \mathrm{ZW}$ & Millieextinktionseinheiten pro mg eingesetzte Zellwandprobe \\
\hline $\min$ & Minute \\
\hline $\mathrm{ml}$ & Milliliter \\
\hline$\mu 1$ & Mikroliter \\
\hline $\mathrm{mM}$ & Millimol \\
\hline $\mathrm{mm}$ & Millimeter \\
\hline$\mu \mathrm{m}$ & Mikrometer \\
\hline $\mathrm{mV}$ & Millivolt \\
\hline $\mathrm{N}$ & Normal \\
\hline $\mathrm{NaCl}$ & Natriumchlorid \\
\hline NADP & Nicotinamidadenindinucleotidphosphat \\
\hline NADPH & reduziertes Nicotinamidadenindinucleotidphosphat \\
\hline $\mathrm{NaOH}$ & Natriumhydroxid \\
\hline ng & Nanogramm \\
\hline $\mathrm{Nm}$ & Nanometer \\
\hline Nmol & Nanomol \\
\hline n.s. & nicht signifikant \\
\hline NUV & „near UV“ \\
\hline $\mathrm{O}_{2}$ & Sauerstoff \\
\hline $\mathrm{p}$ & Irrtumswahrscheinlichkeit bei statistischen Berechnungen \\
\hline PCR & Polymerasekettenreaktion \\
\hline PD & Kartoffeldextrose \\
\hline PDA & Kartoffeldextroseagar \\
\hline PEG & Polyethylenglycol \\
\hline $\mathrm{pH}$ & pondus hydrogenii (Säuregrad einer Lsg.) \\
\hline$\%$ & Prozent, Masse pro Volumen \\
\hline rpm & rounds per minute \\
\hline RP-TLC & reversed phase thin layer chromatography \\
\hline $\mathrm{RT}$ & Raumtemperatur \\
\hline SDS & Natriumdodecylsulfat \\
\hline s.o. & siehe oben \\
\hline $\mathrm{T}$ & Tyrosin \\
\hline Tab. & Tabelle \\
\hline Taq & Thermus aquaticus \\
\hline TBE & Trisborsäure-EDTA \\
\hline TBZ & Thiobendazol \\
\hline
\end{tabular}


TE

Tris-EDTA

TRIS Tris(Hydroxymethyl)-aminomethan

u.a. unter anderem

UV Ultra-Violett

V8 Gemüsesaft

vgl. vergleiche

w/v Gewicht pro Volumen

YEPD Hefeextrakt-Pepton-Dextrose 


\section{Einleitung}

Die Kulturpflanze Kartoffel (Solanum tuberosum) wurde in der zweiten Hälfte des 16. Jahrhunderts aus ihrem Ursprungsland Südamerika nach Europa eingeführt und gilt neben Brot auf Grund der ernährungsphysiologisch wertvollen Inhaltsstoffe auch heute noch als zweitwichtigstes Grundnahrungsmittel (PUTZ, 1998). Allein in Europa werden derzeit 1,4 Mio. Hektar Kartoffeln angebaut (Hambloch \& Menth, 2003). Dabei nehmen neben der Frischware die Verarbeitungsprodukte wie Pommes frites, Stärke u. a. einen immer höheren Stellenwert ein (HAmbloch \& MENTH, 2003). Auf Grund der hohen Verbraucheransprüche und der mechanisierten Verarbeitungswege steht dabei der Qualitätsaspekt der Ware im Vordergrund.

Die Kartoffelkrankheit Silberschorf, hervorgerufen durch den Deuteromyceten (Fungi imperfecti) Helminthosporium solani (Dur. et Mont.), stellt eine weltweit vorkommende Krankheit dar (HOOKER, 1981), die ausschließlich die Kartoffelknollen befällt (ERRAMPALli et al., 2001a; RADTKE et al., 2000). Das Teleomorph des Pilzes wurde noch nicht beschrieben, die phylogenetische Position des Pilzes ist noch ungeklärt (ERrampalli et al., 2001a). Das Myzel ist dunkel, während Konidiophoren und Konidien direkt aus dem Stromata hervorgehen (BARNETT \& HUNTER, 1998). Ein Konidiophor bringt je nach Isolat 5-30 Konidien hervor, die Konidien sind zylindrisch, dunkel, in 3-10 Segmente unterteilt, leicht konkav und dickwandig (HuNGER \& MCINTYRE, 1979). Ihre Größe reicht von 15-64 $\mu \mathrm{m}$ in der Länge und 4-8,1 $\mu \mathrm{m}$ in der Breite (Hunger \& MCINTyRe, 1979). Temperaturen zwischen $15-25^{\circ} \mathrm{C}$ und hohe Luftfeuchtigkeit regen den Pilz zur Keimung an (ERRAMPALLI et al., 2001a). Als Wirtspflanzen sind keine anderen Pflanzen als Kartoffeln bekannt (KAMARA \& Hugelet, 1972; BAINS et al., 1996) während der Pilz nekrotroph auf verschiedenen Substraten wie z.B. abgestorbenen Haferblättern leben kann (KAMARA \& HUGUELET, 1972; MERIDA \& LORIA, 1994b).

Die Krankheit spielte im Kartoffelbau bis vor wenigen Jahren eine untergeordnete Rolle (Melhus, 1913; Schultz, 1916; Hunger \& McInTYre, 1979). In den letzten 10-15 Jahren ist deren Bedeutung jedoch weltweit deutlich angestiegen (STECK \& ZELLNER, 2002; RAdtKe et al., 2000; Schwaerzel, 2003; Errampalli et al., 2001a). Diese Entwicklung begründet sich hauptsächlich auf der veränderten Vermarktung der Knollen, durch Waschen und Abpacken (HARDY et al., 1997), sowie deren oben 
erwähnter industrieller Verarbeitung (SECOR, 1993; RODRIGUEZ et al., 1996; ERRAMPALLI et al., 2001a). Die Krankheit entwickelt sich hauptsächlich im Lager durch Bildung und Verbreitung von Konidien (Peters, 1999; Fireman \& Allen, 1995), welche entweder durch die Ausbreitung von Staub oder den Kontakt gesunder mit infizierten Knollen übertragen werden (RodrigueZ et al., 1996; PETERS, 1999). Daher spielen die Lagerhygiene und Lagerführung eine wichtige Rolle in der Ausbreitung der Krankheit. Wie der Pilz im Feld von Mutter- auf Tochterknolle übertragen wird, ist noch unklar. Verseuchtes Pflanzgut gilt als Hauptinokulumsquelle (BURKE, 1938; Hunger \& MCINTYRE, 1979) wobei ein langdauerndes Überleben im Boden diskutiert wird (HoOKer, 1981; Kamara \& Huguelet, 1972; Merida \& Loria, 1994b). In wieweit der Pilz bodenbürtig ist, ist noch ungeklärt.

Der Erreger dringt auf noch nicht ganz geklärtem Weg in das Periderm ein und breitet sich intrazellulär vermutlich bis in die cortikalen Zellschichten aus (HEINY \& MCINTYRE, 1983; MARTINEZ et al., 2004). Im Krankheitsverlauf kollabiert das Periderm, welches sich darauf von der darunter liegenden Cortexschicht löst (HEINY \& MCINTYRE, 1983; RADTKE et al., 2000). Dies verursacht auf der Knollenoberfläche silbergraue, unregelmäßige Flecken unterschiedlicher Größe (STEVENSON et al., 2001) (Abb. 1). Die Vermehrung erfolgt wieder über Konidien, die wiederum andere Knollen penetrieren können (RADTKE et al., 2000).

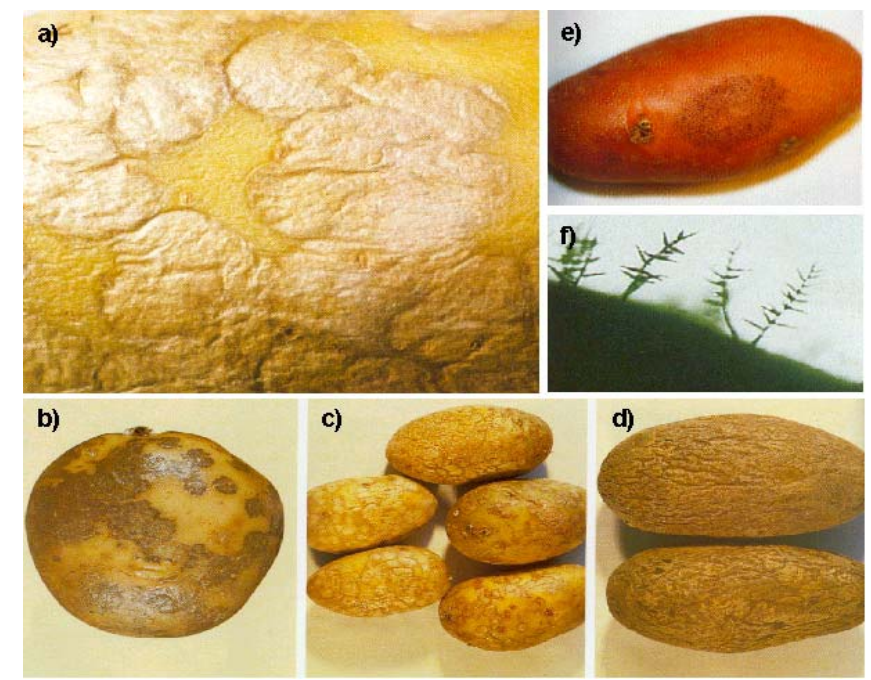

Abbildung 1: Silberschorf auf Kartoffelknollen. a) und b) Die silbrig-braun glänzende Läsion zeigt den von $H$. solani befallenen Teil der Knolle. c) und d) Die ungeschützte Knolle verliert an Wasser. Gewichtsverlust, Unansehnlichkeit (RADTKE et al., 2000) und verminderte Triebkraft (STECK, 2002) sind die Folge. e) und f) Der Pilz bildet Konidien, die überall, aber hauptsächlich am Rand der Läsionen entstehen (aus RADTKE et al., 2000).

Die silbergraue Farbe beruht auf einem Verlust von Pigmenten durch Zelldegradation und Suberinanlagerung (FrAZIER et al., 1998). Durch die eindringende Luft beginnt die 
ungeschützte Knolle im Lager stark Wasser zu verlieren und zu schrumpeln (HUNGER \& MCINTYRE, 1979), wodurch Gewichtsabnahmen von 5-7 \% durch Wasserverlust entstehen können (JELLIS \& TAYLOR, 1977; RADTKE et al., 2000). Nach der Lagerperiode im Frühjahr sind bei manchen Sorten häufig über $50 \%$ der Knollen mit Silberschorf befallen, wobei oft mehr als $20 \%$ der Knollenoberfläche mit Silberschorfläsionen bedeckt sind (STACHEWICZ et al., 2001). Dies führt zu einer verminderten Triebkraft und kann zu Fehlstellen beim Auflaufen der Pflanzen führen (STECK, 2002), was in Ertragsverlusten resultiert (SCHEID, 2000; RADTKE et al., 2000). Der Wasserverlust fördert zudem den physiologischen Alterungsprozess des Gewebes und kann somit auch eine Zunahme der Schwarzfleckigkeit verursachen (LANGERFELD, 1985).

Die Symptome von Silberschorf werden oft mit denen von Colletotrichum coccodes verwechselt (CARNEGIE et al., 2003), der denselben Lebensraum wie $H$. solani beansprucht und somit möglicherweise mit diesem in Konkurrenz steht.

Die Bekämpfung des Erregers stellt sich äußerst schwierig dar. Pflanzenbauliche Maßnahmen zeigen zwar gewisse Wirkung im Feld (PETERS et al., 2003), helfen aber auf Grund der erst im Lager ansteigenden Ausbreitung (PETERS, 1999) insgesamt nur wenig. Auch der Einsatz von Fungiziden erwies sich als schwierig. Das 1968 auf dem Markt erhältliche Thiobendazol (TBZ) zeigte anfangs gute Wirkung gegen $H$. solani (HIDE et al. 1969) bei Applikation auf die Knollen direkt nach der Ernte. Ab 1977 traten jedoch immer verstärkter Resistenzen des Pilzes gegen den Wirkstoff auf (HIDE et al. 1988; Hide \& HALl, 1993; KAWCHUCK et al., 1994; SAUNDERS \& ERRAMPALLI, 2001). Ab 1988 war der Großteil aller H. solani Stämme resistent während der Einsatz anderer Fungizide wie Imazalil (TSROR \& PERETZ, 2002) nur unzureichend Wirkung zeigte und auch hier die Problematik der Resistenzen schnell auftrat (ERRAMPALLI et al., 2001a). Zur Zeit steht in Deutschland nur ein Fungizid, nämlich MoncerenPlus ${ }^{\circledR}$ (Wirkstoffe: Pencycuron $75 \mathrm{~g} / \mathrm{kg}$ und Tolylfluanid $100 \mathrm{~g} / \mathrm{kg}$ ), zur Verfügung, das jedoch, auch auf Grund der Applikation bei Pflanzung, eine unzureichende Wirkung zeigt (PICKNEY, 2002). Auch eine biologische Kontrolle der Krankheit durch Einsatz von Antagonisten wurde erwägt, zeigte aber keinen wirklichen Schutz vor Silberschorf (ERRAMPALLI et al., 2001a). In einer Studie von MichAud et al. (2002) wurden kürzlich einige interessante Antagonisten gefunden, deren Einfluss auf Silberschorf unter Feldbedingungen jedoch noch gänzlich ungeklärt ist. 
Eine Lösung des Problems könnte die Züchtung resistenter Kartoffelsorten darstellen. In früheren Arbeiten wurde festgestellt, dass verschiedene Kartoffelsorten unterschiedliche Anfälligkeit gegenüber Silberschorf aufweisen (MERIDA \& LORIA, 1994b; SECOR, 1994). Eine völlig resistente Sorte wurde nicht gefunden, wobei keine genaueren Daten zum Einfluss von äußeren Faktoren wie Wetter, Klima oder Boden auf die Anfälligkeit der Sorten existieren. Auch Untersuchungen zu den Ursachen der Resistenzunterschiede wurden bisher nicht angestrengt.

Ziel der Arbeit war es daher, die Resistenz verschiedener Kartoffelgenotypen zu bestimmen und so ein Standardsortiment von anfälligen bis wenig anfälligen Sorten als Vergleichssortiment für spätere Prüfungen zu erarbeiten. Dabei musste in erster Linie der Einfluss von äußeren Faktoren auf die Anfälligkeit der unterschiedlichen Sorten untersucht und nach Möglichkeit ausgeschlossen werden. Auch die Auswirkung einer möglichen Konkurrenz zwischen H. solani mit $C$. coccodes auf den Silberschorfbefall sollte hierbei berücksichtigt werden.

Auf diesem Standardsortiment aufbauend sollten anschließend in Laboruntersuchungen die von wenig anfälligen Sorten erzeugten Abwehrmechanismen (Resistenzfaktoren) im Vergleich $\mathrm{zu}$ anfälligen Sorten durch morphologische, biochemische und mikroskopische Methoden aufgeklärt werden. Eine lichtmikroskopische Methode zur Untersuchung der Penetration der Peridermzellen durch $H$. solani sollte in diesem Rahmen optimiert werden.

Zudem war es wichtig, den genauen Übertragungsweg des Pilzes von Mutter- auf Tochterknollen zu erforschen. Damit sollte das Verständnis des Lebenszyklus des Pilzes verbessert werden, um dieses Wissen für die Züchtung resistenter Sorten nutzbar zu machen. Dazu sollten Gewächshausversuche wie auch biochemische und molekularbiologische Experimente durchgeführt werden. 


\section{Material und Methoden}

\section{Verbrauchsmaterialien und Geräte}

Kühlschrankbeh. 21,5x21,5x5,5 cm Firma Hilba Kunststofferzeugnisse, Göttingen

Casanet - Gitter

Mantis Beizgerät

Fuchs - Rosenthal Zählkammer

Kugelmühle

Ultraschallbad Sonorex RK100

Zentrifugen:

„mini spin plus“"

„Universal $30 \mathrm{RF}^{\prime}$

HPLC - Anlage:

Pumpen: Pump system 32x

Säulen:

Phenolische Verbindungen:

Synergi HydroRP-18 250x4,6mm Phenomenex ${ }^{\circledR}$, Aschaffenburg

Phytoalexine:

Synergi $4 \mu$ HydroRP 80A, 250x4,6mm Phenomenex ${ }^{\circledR}$, Aschaffenburg

Autosampler 360

Detector 432

Feinwaage MC1

DC Platten Kieselgel $60 \mathrm{~F}_{254}$

Rückflusskühler

Mikrotom LeicaVT 1000M

Mikroskop Leitz DMRB

Binokular Leica Wild M10

Bildbearbeitungsprogramm

Kamera Leica DFC300FX

Petrischalen (9 mm)

Schüttler: Chin-O-Shake

Thermocycler TGradient

Gefriertrocknung Christ alpha 1-4
Firma Lünemann, Göttingen

Leihgabe der KTBL, Dethlingen

BRAND GmbH \& CO KG, Wertheim

RETSCH Labortechnik GmbH, Haan

Bandelin Ectronic, Berlin

EPPENDORF Laborzentrifugen $\mathrm{GmbH}$, Hamburg

Andreas Hettich GmbH \& CO KG, Tuttlingen

KONTRON INSTRUMENTS, Neufahrn
KONTRON INSTRUMENTS, Neufahrn

KONTRON INSTRUMENTS, Neufahrn

Satorius GmbH, Göttingen

MERCK® Eurolab GmbH, Darmstadt

SCHÜTT Labortechnik GmbH, Göttingen

LEICA Camera AG, Solms

LEICA Camera AG, Solms

LEICA Camera AG, Solms

Imatec elektr. Bildanalysesyst. GmbH, Miesbach

LEICA Camera AG, Solms

SARSTEDT, Nümbrecht

Adolf Kuhner AG, Basel, Schweiz

BIOMETRA $® \mathrm{GmbH}$, Göttingen

SCHÜTT Labortechnik GmbH, Göttingen 
UV - Transiluminator Gel Doc 1000BioRad Laboratories GmbH, München

Celluloseacetat - Membran

Glasfilter $595 \mathrm{~mm}$

Faltenfilter $385 \mathrm{~mm}$

Parafilm

Invisorb®SPIN Plant Mini Kit

Reaktionsgefäße

Pipettenspitzen

$15 \mathrm{ml} / 50 \mathrm{ml}$ Röhrchen

Pasteurpipetten

Petrischalen

Ultrathurrax
Satorius AG, Göttingen

Schleicher \& Schuell, Dassel

Schleicher \& Schuell, Dassel

Pechiney Plastic Pack., Inc.; Shelbyville, TN USA

INVITEK GmbH, Göttingen

BIOZYM DIAGNOSTIK GmbH, Hess. Oldendorf BIOZYM DIAGNOSTIK GmbH, Hess. Oldendorf

SARTSTEDT, Nümbrecht

SCHÜTT Labortechnik GmbH, Göttingen

SCHÜTT Labortechnik GmbH, Göttingen

Janke \& Ninkel GmbH, München

Düsen:

Agrotop Albuz ${ }^{\circledR}$ APG $20^{\circ}$ orange AgrarTechnik Günther, Rosdorf

Material für Pflanzrinnen:

(Abflussrohr, PVC - Platten)

Lünemann GmbH, Göttingen

Hochdruckspritze

Gloria Werke, Waderloh

Tageslichtlampen

Poot Licht Energie, Schiploiden, Holland

Sacc./D-Glucose/D-Frustose Test

BIOPHARM/ROCHE, Darmstadt, Mannheim

Photometer Spectronic 601

Milton Roy (U.K.) Ltd, Stuffs, England

\section{Chemikalien und Biochemikalien}

Soweit nicht in der Liste aufgeführt, wurden alle verwendeten Chemikalien bei der Firma Carl Roth ${ }^{\circledR}$, Karlsruhe bezogen.
BACTO - PEPTONE
Bengal - Rosa
Calciumcarbonat
Calcofluor
Comassie-Brilliant-Blau R - 250
DNA GrößenStandard

Streptomycin
MERCK ${ }^{\circledR}$ Eurolab GmbH, Darmstadt SERVA Feinchemikalien, Heidelberg MERCK ${ }^{\circledR}$ Eurolab GmbH, Darmstadt SIGMA ALDRICH ChemieGmbH, Deisenhofen SERVA Feinchemikalien Heidelberg GENE RULE GIBCO BRL., Gaithersburg, Maryland, USA

MERCK® Eurolab GmbH, Darmstadt 
Ethidium Bromid

Kartoffel Dextrose

Hefe Extrakt

Gemüsesaft

Malzextrakt - Agar

Mineralöl

Monceren ${ }^{\circledR}$

Thioglycolsäure

Taq - DNA Polymerase
FLUCA Chemie GmbH, Buchs

DIFCO, Detroit, Michigan, USA

MERCK ${ }^{\circledR}$ Eurolab GmbH, Darmstadt

Tip Goldhand VertriebsgmbH Düsseldorf

MERCK® Eurolab GmbH, Darmstadt

MERCK ${ }^{\circledR}$ Eurolab GmbH, Darmstadt

Syngenta Agro GmbH, Basel, Schweiz

SIGMA ALDRICH Chemie GmbH, Deisenhofen

MBI-Fermentas, St. Leon Roth

Tabelle 1: Standardsubstanzen HPLC

\begin{tabular}{|c|c|}
\hline Standardsubstanzen & Bezugsquelle \\
\hline Ferulasäure & Firma Carl Roth ${ }^{\circledR}$, Karlsruhe \\
\hline Anissäure & Firma Carl Roth ${ }^{\circledR}$, Karlsruhe \\
\hline p-Cumarsäure & Firma Carl Roth ${ }^{\circledR}$, Karlsruhe \\
\hline Sinapinsäure & Firma Carl Roth ${ }^{\circledR}$, Karlsruhe \\
\hline trans - Zimtsäure & $\begin{array}{l}\text { SIGMA - ALDRICH Chemie GmbH, } \\
\text { Deisenhofen }\end{array}$ \\
\hline p-Methoxyzimtsäure & $\begin{array}{l}\text { SIGMA - ALDRICH Chemie GmbH, } \\
\text { Deisenhofen }\end{array}$ \\
\hline 2,4-Dimetoxyzimtsäure & $\begin{array}{l}\text { SIGMA - ALDRICH Chemie GmbH, } \\
\text { Deisenhofen }\end{array}$ \\
\hline Vanillinsäure & Firma Carl Roth ${ }^{\circledR}$, Karlsruhe \\
\hline p-Hydroxybenzoesäure & Firma Carl Roth ${ }^{\circledR}$, Karlsruhe \\
\hline Syringasäure & Firma Carl Roth ${ }^{\circledR}$, Karlsruhe \\
\hline Gallussäure & Firma Carl Roth $®$, Karlsruhe \\
\hline Vanillin & Firma Carl Roth ${ }^{2}$, Karlsruhe \\
\hline p-Hydroxybenzaldehyd & Firma Carl Roth ${ }^{\circ}$, Karlsruhe \\
\hline Syringaaldehyd & Firma Carl Roth $\AA$, Karlsruhe \\
\hline 2,4-Dimethoxybenzaldehyd & $\begin{array}{l}\text { SIGMA - ALDRICH Chemie GmbH, } \\
\text { Deisenhofen }\end{array}$ \\
\hline
\end{tabular}


Tabelle 2: Verwendete Oligonukleotide

\begin{tabular}{|l|l|l|l|}
\hline Primer & Größe & Sequenz & Bemerkung und Referenz \\
\hline ITS 4 & $20 \mathrm{mer}$ & TCCTCCGCTTATTGATATGC & WHITE et al. 1990 \\
\hline ITS 5 & $22 \mathrm{mer}$ & GGAAGTAAAAGTCGTAACAAGG & WHITE et al. 1990 \\
\hline HRS 120 & $24 \mathrm{mer}$ & TCCCTTAAACCCTTGTATCTGAAG & OLIVIER et al. 1998 \\
\hline HRS 465 & $23 \mathrm{mer}$ & TGGTCCACCAGGGCTTCAAGAAG & OLIVIER et al. 1998 \\
\hline HSF 19 & $20 \mathrm{mer}$ & AAGGACATTACGTTTCAGCG & OLIVIER et al. 1998 \\
\hline HRS 447 & $23 \mathrm{mer}$ & AGAAGCGCAATGTGCTGCACGAG & OLIVIER et al. 1998 \\
\hline
\end{tabular}

\section{Medien und Puffer}

Die Nährmedien wurden autoklaviert $\left(121^{\circ} \mathrm{C}, 20 \mathrm{~min}\right)$ und der $\mathrm{pH}$ bei Bedarf (Hafermehlmedium) mit $\mathrm{NaOH}$ bzw. $\mathrm{HCl}$ eingestellt.

\section{V8 - Medium}

Gemüsesaft

$100 \mathrm{ml}$

Calciumcarbonat

$2 \mathrm{~g}$

Destilliertes Wasser

$1000 \mathrm{ml}$

Agar - Agar (bei Festmedien)

$15 \mathrm{~g}$

\section{Hefe Extrakt Medium (YEPD)}

BACTO - PEPTONE

$20 \mathrm{~g}$

Hefe Extrakt

$10 \mathrm{~g}$

D - Glucose

$20 \mathrm{~g}$

Destilliertes Wasser

$1000 \mathrm{ml}$

Agar - Agar (bei Festmedien)

$20 \mathrm{~g}$

\section{Malxextrakt - Medium}

Malzextrakt

$48 \mathrm{~g}$

Destilliertes Wasser

$1000 \mathrm{ml}$

Agar - Agar (bei Festmedien)

$20 \mathrm{~g}$ 
Malz - Pepton Medium

Biomalz

$30 \mathrm{~g}$

Pepton

$5 \mathrm{~g}$

Destilliertes Wasser

$1000 \mathrm{ml}$

Czapek - Dox Medium

$\begin{array}{ll}\mathrm{NaNO}_{3} & 2,0 \mathrm{~g} \\ \mathrm{~K}_{2} \mathrm{HPO}_{4} \times 3 \mathrm{H}_{2} \mathrm{O} & 1,3 \mathrm{~g} \\ \mathrm{MgSO}_{4} \times 7 \mathrm{H}_{2} \mathrm{O} & 0,5 \mathrm{~g} \\ \mathrm{KCl} & 0,5 \mathrm{~g} \\ \mathrm{FeSO}_{4} \times 7 \mathrm{H}_{2} \mathrm{O} & 0,01 \mathrm{~g} \\ \text { Pepton aus Casein } & 0,2 \mathrm{~g} \\ \text { Destilliertes Wasser } & 500 \mathrm{ml} \\ \text { Agar - Agar (bei Festmedien) } & 15 \mathrm{~g}\end{array}$

\section{Kartoffel Dextrose (PD) Medium}

Kartoffel Dextrose

$20 \mathrm{~g}$

Destilliertes Wasser

$1000 \mathrm{ml}$

Agar - Agar (bei Festmedien)

$15 \mathrm{~g}$

\section{Hafermehl - Medium pH 6}

Hafer gemahlen (ca. 4 mm)

$10 \mathrm{~g}$

Destilliertes Wasser $500 \mathrm{~g}$

Agar - Agar (bei Agar - Platten)

$15 \mathrm{~g}$

Das Wasser wurde mit dem Hafermehl vermischt und autoklaviert. Das Gemisch wurde anschließend mit einem Faltenfilter filtriert, auf $1000 \mathrm{ml}$ mit destilliertem Wasser aufgefüllt, der $\mathrm{pH}$ Wert eingestellt, Agar - Agar zugegeben und erneut autoklaviert.

\section{Wasseragar}

Agar-Agar

$15 \mathrm{~g}$

Destilliertes Wasser

$500 \mathrm{~g}$ 


\section{Ladepuffer für Gelelektrophorese}

$30 \% \mathrm{w} / \mathrm{v}$ Glycerin

$0,25 \% \mathrm{w} / \mathrm{v}$ Bromphenolbau

$0,25 \% \mathrm{w} / \mathrm{v}$ Xylencyanol

TBE - Puffer 10x

0,9 M Tris

$5,5 \% \mathrm{w} / \mathrm{v}$ Borsäure

$4 \% \mathrm{w} / \mathrm{v}$ 0,5 M EDTA pH 8,0

Destilliertes Wasser $1000 \mathrm{ml}$

TE - Puffer

$0,1 \mathrm{M}$ Tris $\mathrm{pH} 8,0$

$10 \mathrm{mM}$ EDTA

\section{CTAB Lösung}

$10 \%(w / v)$ Cethyltrimethylammoniumbromid (CTAB) in $0,7 \mathrm{M} \mathrm{NaCl}$ und $1 \mathrm{x}$ TE -

Puffer

\section{Pilz- und Pflanzenmaterial}

Tabelle 2: Verwendete Helminthosporium solani Stämme

\begin{tabular}{|l|l|}
\hline Stamm & Bemerkung und Referenz \\
\hline H9-2a & $\begin{array}{l}\text { Isoliert von C. Hühne aus der Arbeitsgruppe Allgemeine Pflanzenpathologie } \\
\text { und Pflanzenschutz (Institut für Pflanzenpathologie und Pflanzenschutz, } \\
\text { Göttingen) aus Lagerhalle H9 der KTBL Dethlingen }\end{array}$ \\
\hline BBA & Zur Verfügung gestellt von der Biologischen Bundesanstalt, Braunschweig \\
\hline Post D8 & $\begin{array}{l}\text { Isoliert von C. Hühne aus der Arbeitsgruppe Allgemeine Pflanzenpathologie } \\
\text { und Pflanzenschutz (Institut für Pflanzenpathologie und Pflanzenschutz, } \\
\text { Göttingen) aus Lagerhalle der KTBL Dethlingen }\end{array}$ \\
\hline Post D7 & $\begin{array}{l}\text { Isoliert von C. Hühne aus der Arbeitsgruppe Allgemeine Pflanzenpathologie } \\
\text { und Pflanzenschutz (Institut für Pflanzenpathologie und Pflanzenschutz, } \\
\text { Göttingen) aus Lagerhalle der KTBL Dethlingen }\end{array}$ \\
\hline Rot 1 & $\begin{array}{l}\text { Isoliert von C. Hühne aus der Arbeitsgruppe Allgemeine Pflanzenpathologie } \\
\text { und Pflanzenschutz (Institut für Pflanzenpathologie und Pflanzenschutz, } \\
\text { Göttingen) aus Lagerhalle der KTBL Dethlingen }\end{array}$ \\
\hline KTBL - b & $\begin{array}{l}\text { Isoliert von C. Hühne aus der Arbeitsgruppe Allgemeine Pflanzenpathologie } \\
\text { und Pflanzenschutz (Institut für Pflanzenpathologie und Pflanzenschutz, }\end{array}$ \\
\hline
\end{tabular}




\begin{tabular}{|c|c|}
\hline & Göttingen) aus Lagerhalle der KTBL Dethlingen \\
\hline „Hofferbert"“ & Zur Verfügung gestellt von Böhm-Nordkartoffel-Agrarprodukte OhG \\
\hline „Secura“6 & Im Rahmen dieser Arbeit von Knollen der Sorte Secura isoliert \\
\hline „Karlena“ & Im Rahmen dieser Arbeit von Knollen der Sorte Karlena isoliert \\
\hline $6 \mathrm{~b}$ & Im Rahmen dieser Arbeit von Knollen unbekannter Sorte isoliert \\
\hline $5 \mathrm{~d}$ & Im Rahmen dieser Arbeit von Knollen unbekannter Sorte isoliert \\
\hline $5 \mathrm{c}$ & Im Rahmen dieser Arbeit von Knollen unbekannter Sorte isoliert \\
\hline $5 \mathrm{a}$ & Im Rahmen dieser Arbeit von Knollen unbekannter Sorte isoliert \\
\hline $4 \mathrm{~d}$ & Im Rahmen dieser Arbeit von Knollen unbekannter Sorte isoliert \\
\hline $4 \mathrm{c}$ & Im Rahmen dieser Arbeit von Knollen unbekannter Sorte isoliert \\
\hline $4 \mathrm{a}$ & Im Rahmen dieser Arbeit von Knollen unbekannter Sorte isoliert \\
\hline $2 \mathrm{~d}$ & Im Rahmen dieser Arbeit von Knollen unbekannter Sorte isoliert \\
\hline $1 \mathrm{a}-5$ & $\begin{array}{l}\text { Isoliert von C. Hühne aus der Arbeitsgruppe Allgemeine Pflanzenpathologie } \\
\text { und Pflanzenschutz (Institut für Pflanzenpathologie und Pflanzenschutz, } \\
\text { Göttingen) aus Lagerhalle H9 der KTBL Dethlingen }\end{array}$ \\
\hline $\mathrm{H} 9-20 \mathrm{a}$ & $\begin{array}{l}\text { Isoliert von C. Hühne aus der Arbeitsgruppe Allgemeine Pflanzenpathologie } \\
\text { und Pflanzenschutz (Institut für Pflanzenpathologie und Pflanzenschutz, } \\
\text { Göttingen) aus Lagerhalle H9 der KTBL Dethlingen }\end{array}$ \\
\hline $\mathrm{H} 9-17 \mathrm{~b}$ & $\begin{array}{l}\text { Isoliert von C. Hühne aus der Arbeitsgruppe Allgemeine Pflanzenpathologie } \\
\text { und Pflanzenschutz (Institut für Pflanzenpathologie und Pflanzenschutz, } \\
\text { Göttingen) aus Lagerhalle H9 der KTBL Dethlingen }\end{array}$ \\
\hline $\mathrm{H} 9-16 \mathrm{~b}$ & $\begin{array}{l}\text { Isoliert von C. Hühne aus der Arbeitsgruppe Allgemeine Pflanzenpathologie } \\
\text { und Pflanzenschutz (Institut für Pflanzenpathologie und Pflanzenschutz, } \\
\text { Göttingen) aus Lagerhalle H9 der KTBL Dethlingen }\end{array}$ \\
\hline $\mathrm{H} 9-15 \mathrm{~b}$ & $\begin{array}{l}\text { Isoliert von C. Hühne aus der Arbeitsgruppe Allgemeine Pflanzenpathologie } \\
\text { und Pflanzenschutz (Institut für Pflanzenpathologie und Pflanzenschutz, } \\
\text { Göttingen) aus Lagerhalle H9 der KTBL Dethlingen }\end{array}$ \\
\hline $\mathrm{H} 9-13 \mathrm{~b}$ & $\begin{array}{l}\text { Isoliert von C. Hühne aus der Arbeitsgruppe Allgemeine Pflanzenpathologie } \\
\text { und Pflanzenschutz (Institut für Pflanzenpathologie und Pflanzenschutz, } \\
\text { Göttingen) aus Lagerhalle H9 der KTBL Dethlingen }\end{array}$ \\
\hline H9-9a & $\begin{array}{l}\text { Isoliert von C. Hühne aus der Arbeitsgruppe Allgemeine Pflanzenpathologie } \\
\text { und Pflanzenschutz (Institut für Pflanzenpathologie und Pflanzenschutz, } \\
\text { Göttingen) aus Lagerhalle H9 der KTBL Dethlingen }\end{array}$ \\
\hline
\end{tabular}

Neben H. solani wurde ein Cladosporium spp. Stamm verwendet, der von Frau E. Vorbeck aus der Arbeitsgruppe Allgemeine Pflanzenpathologie und Pflanzenschutz (Institut für Pflanzenpathologie und Pflanzenschutz, Göttingen) isoliert wurde.

Tabelle 3: Verwendete Kartoffelgenotypen

\begin{tabular}{|l|l|}
\hline Kartoffelgenotyp & Züchter \\
\hline Laura & Böhm-Nordkartoffel-Agrarprodukte OhG \\
\hline Marabel & Böhm-Nordkartoffel-Agrarprodukte OhG \\
\hline Nicola & Böhm-Nordkartoffel-Agrarprodukte OhG \\
\hline Solara & Böhm-Nordkartoffel-Agrarprodukte OhG \\
\hline
\end{tabular}




\begin{tabular}{|l|l|}
\hline Princess & SaKa - Ragis Pflanzgut GbR \\
\hline Secura & SaKa - Ragis Pflanzgut GbR \\
\hline Acapella & Norika GmbH \\
\hline Arcula & Norika GmbH \\
\hline Karlena & Norika GmbH \\
\hline Bernadette & Saatzucht Fritz Lange KG \\
\hline Franzi & Bavaria - Saat München \\
\hline Edelstein & Saatzucht Firlbeck KG \\
\hline
\end{tabular}

\section{Isolierung und Anzucht von Pilzmaterial}

\subsection{Isolierung von Helminthosporium solani von Kartoffelknollen und Anlegen einer Isolatesammlung}

Kartoffelknollen mit sichtbaren Silberschorf Symptomen wurden gereinigt, oberflächlich mit $96 \%$ Ethanol sterilisiert und in Feuchtekammern (Boxentest) 1-2 Wochen eingelagert um den Pilz zum Sporulieren anzuregen. Nach der Inkubation wurden vorsichtig unter dem Mikroskop Konidien von H. solani mit einer Lanzettnadel abgenommen und auf Wasseragar überführt. Nach 3 Tagen Inkubation bei $20{ }^{\circ} \mathrm{C}$ im Dunkeln wurden die gekeimten Konidien auf V8-Agarplatten mit Streptomycin und Bengal Rosa überimpft. Nach zehnwöchiger Inkubation und mehrfachem Umsetzen des Pilzes auf neue Platten zur Ausschließung von Kontaminanten wurden die $H$. solani Konidien mit autoklaviertem Wasser von den Platten gewaschen. Eine Verdünnungsreihe der Konidiensuspension wurde ausplattiert um Einzelsporen - Isolate zu erhalten. Kolonien von einzelnen Sporen wurden wiederum auf neue V8-Agarplatten mit Streptomycin und Bengal Rosa gesetzt und 6 Wochen bei $16^{\circ} \mathrm{C}$ im Dunkeln inkubiert. Abschließend wurden Proben der so gewonnenen Isolate auf Hafermehlagar in Schrägröhrchen überführt und wiederum für 2 Wochen bei Raumtemperatur im Dunkeln inkubiert. Die Schrägröhrchen wurden zum Schluss mit Mineralöl (Fa. Carl Roth ${ }^{\circledR}$, Karlsruhe) überschichtet und bei $4{ }^{\circ} \mathrm{C}$ gelagert. 


\subsection{Isolierung von $\boldsymbol{H}$. solani aus Bodenproben mit Bengal Rosa}

Da H. solani ein im Gegensatz zu anderen bodenbürtigen Erregern sehr langsames Wachstum auf Nährmedien zeigt, ist eine Isolierung des Pilzes aus Bodenproben sehr schwierig. Daher wurde der Einsatz von Bengal Rosa als Selektionszusatz unter verschiedenen Temperaturbedingungen getestet. Bengal Rosa bildet unter Lichteinfluss Radikale, die das Wachstum vieler Pilze stark unterdrücken. V8-Agar mit 200 ppm Streptomycin wurde mit 80 ppm Bengal Rosa versetzt. Zunächst wurde das Wachstum von $H$. solani selbst getestet, indem Myzelstückchen auf 5 der oben beschriebenen Platten überimpft wurden und diese bei $16^{\circ} \mathrm{C}$ im Dunkeln für ca. 4 Wochen inkubiert wurden. Als Kontrolle wurden 5 beimpfte V8-Agarplatten ohne den Zusatz von Bengal Rosa mitgeführt. Nach der Inkubation wurden die Kolonien vermessen, die Konidienanzahl in der Fuchs-Rosenthal Zählkammer bestimmt und die Platten mit und ohne Bengal Rosa miteinander verglichen. Des Weiteren wurden 8 g Bodenproben mit $10 \mathrm{ml}$ einer Silberschorf Konidiensuspension von $10^{4}-10^{5}$ Konidien $/ \mathrm{ml}$ versetzt und eine wässrige Verdünnungsreihe der Suspension von $10^{-1}-10^{-4}$ hergestellt. Für jede Verdünnungsstufe wurden 12 V8-Streptomycin-Bengal Rosa Platten mit $100 \mu 1$ Suspension angeimpft, die mit dem Drigalskispatel gleichmäßig verteilt wurde. Um den Einfluss der Temperatur $\mathrm{zu}$ überprüfen wurden jeweils 3 Platten jeder Verdünnungsstufe bei $8^{\circ} \mathrm{C}, 12^{\circ} \mathrm{C}, 16^{\circ} \mathrm{C}$ und $20^{\circ} \mathrm{C}$ inkubiert. Nach $2,4,6,8$ und 10 Tagen wurde das Wachstum auf den Platten unter dem Binokular kontrolliert und, falls vorhanden Silberschorfkolonien vorsichtig auf neue V8 - Streptomycin - Bengal Rosa Platten überimpft. Die $H$. solani Kolonien wurden gezählt und verglichen und somit die optimale Temperatur festgestellt. Außerdem wurden nach Abschluss des Versuchs alle Platten unter dem Mikroskop auf ungekeimte Silberschorfkonidien soweit wie möglich überprüft. Bei diesen Versuchen wurde ein für Silberschorf schnellwüchsiges $H$. solani Isolat kultiviert, welches von der Biologischen Bundesanstalt Braunschweig (BBA) zur Verfügung gestellt wurde. Der Versuch wurde zweimal wiederholt. 


\subsection{Flotationsverfahren zur Isolierung von $\boldsymbol{H}$. solani Konidien aus Bodenproben}

Bei diesem Verfahren nach LEDINGHAM \& CHINN (1955) sollte überprüft werden, ob $H$. solani Konidien hydrophobe Eigenschaften haben und dadurch aus Boden isoliert werden können. Bodenproben wurden gesammelt, mit $H$. solani Konidien versetzt und mit Wasser bis zu einem Feuchtigkeitsgrad von $10 \%$ des Trockengewichts der Probe befeuchtet. $\mathrm{Zu} 10 \mathrm{~g}$ der so angefeuchteten Probe wurde $15 \mathrm{ml}$ Mineralöl gemixt und in ein Glasgefäß überführt. Es wurden verschiedene Mineralöle mit unterschiedlicher Viskosität eingesetzt. Die Mixtur wurde in ein Testgefäß überführt und mit $50 \mathrm{ml}$ normalem Leitungswasser versetzt. Nach 5 min schütteln wurde die Probe aufrecht positioniert. In einer Sedimentationsphase von $30 \mathrm{~min}$ setzten sich die meisten Bodenpartikel in der unteren wässrigen Phase ab. Die ölige Phase hielt sich an der Oberfläche. Anschließend wurden Proben der oberen öligen Phase zur Überprüfung von H. solani Konidien mit Hilfe einer Pipette auf einen Objektträger übertragen. Öltropfen und Luftblasen wurden durch Aufrühren mit einer Nadel entfernt und die Mixtur zu einem Film ausgebreitet. Es wurden pro Probe mindestens 10 Tropfen unter einem Mikroskop mit der Vergrößerung $72 \mathrm{x}$ auf $H$. solani Konidien überprüft. Als Gegenkontrolle wurden 10 Tropfen der Wasserphasen ebenfalls mikroskopisch untersucht.

\subsection{Wachstumstest von $H$. solani auf verschiedenen Medien}

Da $H$. solani ein äußerst langsames Wachstum auf Agar-Platten zeigt und auch die Konidienbildung auf Kartoffel-Dextrose Agarplatten (PDA) unbefriedigend ist, wurden einige Ersatzmedien unter verschiedenen Wachstumsbedingungen getestet. Als Testisolat wurde das aggressive und relativ schnellwüchsige Isolat H9 - 5a gewählt. Der Versuch wurde zum einen in Flüssigmedien durchgeführt, zum anderen auf Agarplatten. Bei den Flüssigmedien wurde Malzextraktmedium, YEPD-Medium, Czapek-Dox Medium und zur Kontrolle PD-Medium verwendet. Myzelstücke wurden aus einer PDA-Platte geschnitten und damit je 3 x $200 \mathrm{ml}$ des jeweiligen Mediums angeimpft. Die Proben wurden auf einem Rotationsschüttler bei $20^{\circ} \mathrm{C}$ im Dunkeln für ca. 3 Wochen inkubiert. Das Aussehen der Kolonien wurde visuell überwacht. Nach 5, 10, 15 und 20 Tagen wurden Proben genommen und unter dem Mikroskop auf Konidien 
überprüft. Nach der Inkubationszeit wurden die H. solani Kolonien im Kleinexikator auf einen Glasfilter gesaugt und im Trockenschrank bei ca. $80^{\circ} \mathrm{C}$ getrocknet und das Gewicht ermittelt. Im verbleibenden Restmedium wurden unter dem Mikroskop Stichproben auf Konidien untersucht.

Bei der Untersuchung des Wachstums auf Agarplatten wurde V8-Medium mit Streptomycin, YEPD-Medium und PD-Medium verwendet. Zunächst wurden Myzelstückchen von einer PDA-Platte geschnitten und auf jeweils 10 Agarplatten der verschiedenen Medien gesetzt. Hiervon wurden 5 Platten bei ca. $16^{\circ} \mathrm{C}$ im Dunkeln für 5 Wochen inkubiert. Die restlichen 5 Platten wurden ebenfalls bei ca. $16^{\circ} \mathrm{C}$ aber unter NUV - Dauerlicht 5 Wochen inkubiert. Die Wellenlänge der verwendeten Lampen lag zwischen 350-400 nm, die Platten wurden in $1 \mathrm{~m}$ Abstand $\mathrm{zu}$ den Lichtquellen inkubiert. Das Aussehen der Kolonien auf den verschiedenen Medien wurde visuell überwacht. Anschließend wurde die Wachstumszone des Pilzes vermessen und ein Mittelwert zwischen den 5 Platten bestimmt. Außerdem wurden die Konidien mit $10 \mathrm{ml}$ Leitungswasser abgeschwemmt und in einer Fuchs-Rosenthal Kammer ausgezählt und ebenfalls ein Mittelwert der 5 Platten errechnet. Zwischen den NUV-Varianten und den im Dunkeln gezogenen Platten wurden Signifikanzen errechnet. Der Versuch wurde mehrfach wiederholt.

\subsection{Anzucht von $\boldsymbol{H}$. solani auf Agarplatten}

H. solani wurde von Knollen isoliert und zur dauerhaften Aufbewahrung, wie unter Kapitel 5.1. beschrieben, auf Hafermehl Schrägröhrchen überführt und gelagert. Zur täglichen Benutzung wurden von kontaminationsfreien V8-Agarplatten mit Streptomycin und Bengal Rosa Myzelstückchen mit einem Korkbohrer ausgestanzt und auf neue Platten gesetzt. Die Platten wurden mit Parafilm verschlossen und der Pilz bei $16^{\circ} \mathrm{C}$ im Dunkeln angezogen. Da $H$. solani ein sehr langsames Wachstum zeigt, war eine Inkubation von mindestens 6 Wochen erforderlich. 


\subsection{Anzucht von Cladosporium spp.}

Eine Probe des Pilzes wurde unter der Sterilbank auf Malzextraktagar überimpft und bei $20^{\circ} \mathrm{C}$ bei Tageslicht inkubiert. Nach 14 Tagen waren die Platten voll bewachsen und die Sporen konnten geerntet werden. Dazu wurde die Platte mit $10 \mathrm{ml}$ Wasser überschichtet und die Sporen vorsichtig mit einem Objektträger von der Platte gekratzt.

\section{Befallsbonituren an Kartoffelknollen}

Die zu untersuchenden Kartoffelknollen wurden unter einer Lichtlupe bzw. dem Binokular von allen Seiten visuell begutachtet und der Krankheitsbefall der untersuchten Krankheit geschätzt (Bonitur). Bonitiert wurde grundsätzlich der Prozentsatz an befallener Knollenoberfläche in 10 \% Schritten. Die Knollen wurden in eine daraus resultierende Boniturskala eingeteilt, bei der

$$
\begin{array}{rlrl}
1=10 \% & 6=60 \% \\
2=20 \% & 7=70 \% \\
3=30 \% & 8=80 \% \\
4=40 \% & 9=90 \% \\
5=50 \% & 10=100 \%
\end{array}
$$

befallene Oberfläche entsprach. Zur Unterscheidung zwischen $H$. solani und $C$. coccodes wurden die Läsionen unter dem Binokular auf Silberschorfkonidien bzw. Acervuli oder Sklerotien von C. coccodes überprüft.

\section{Inokulumherstellung und Inokulationsmethoden}

Zur Inokulation wurden vier verschiedene Isolate von Helminthosporium solani mit unterschiedlicher geographischer Herkunft wie in Kapitel 5.1 beschrieben isoliert und auf V8-Agar Platten mit Streptomycin und Bengal Rosa ca. 6 Wochen bei $20^{\circ} \mathrm{C}$ im Dunkeln angezogen. Anschließend wurden die Konidien mit Leitungswasser von den Platten gewaschen und eine Konidiensuspension von $10^{4}-10^{5}$ Konidien/ml mit Hilfe der Fuchs-Rosenthal Zählkammer hergestellt. Dafür wurde zunächst eine Konidiensuspension mit unbekannter Konidienzahl von den Platten gewaschen. Ein Tropfen der Suspension wurde in die Zählkammer gegeben, die Zählung erfolgte unter 
dem Mikroskop. Es wurden jeweils 5 Großquadrate ausgezählt, wobei linienüberschreitende Konidien von jeweils 2 Seiten mitgezählt wurden. Ein Mittelwert der 5 Großquadrate wurde gebildet und die Anzahl mal 80000 genommen. Dadurch kann auf die Konidienzahl/ml der untersuchten Suspension geschlossen werden. Die Konidiensuspension wurde für die Feldversuche in Druckluft-Sprühflaschen gefüllt und die zu inokulierenden Knollen von allen Seiten besprüht. Die Knollen wurden über Nacht getrocknet. In den Gewächshausversuchen wurden die Knollen bei großen Mengen ebenfalls mit einer Druckluft - Sprühflasche mit Konidiensuspension besprüht, bei kleinen Mengen nur in Konidiensuspension getaucht. Auch im Gewächshaus wurden die Knollen anschließend über Nacht getrocknet.

\section{Feldversuche}

Im Versuchsjahr 2002 erfolgte eine Überprüfung der Anfälligkeit verschiedener Kartoffelsorten unter Feldbedingungen mit künstlicher Inokulation an drei Standorten in Deutschland. Es wurden Standorte mit unterschiedlichen Klima- und Bodenverhältnissen gewählt, Windeby in Schleswig-

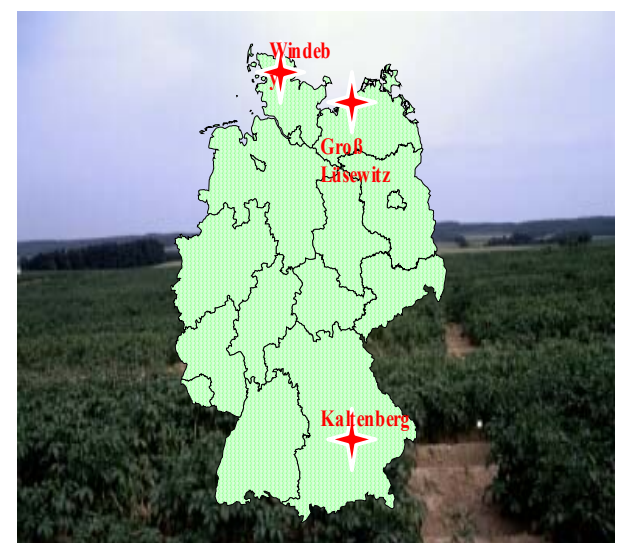

Abbildung 2: Standorte der Feldversuche Holstein mit 45 Bodenpunkten bestehend aus sandigem Lehm, Groß Lüsewitz mit 40 Bodenpunkten lehmigsandig und Kaltenberg mit 35-55 Bodenpunkten sandig bis lehmigsandig (Abb. 2). Geprüft wurden die in Tabelle 2 aufgeführten 12 Kartoffelsorten von 6 Zuchtunternehmen. Die Versuche wurden randomisiert und in vierfacher Wiederholung angelegt. Pro Parzelle wurden 4 Reihen mit jeweils 20 Pflanzen gelegt. Um einen homogenen Befall unter standardisierten Bedingungen zu gewährleisten, wurde das gesamte Pflanzgut künstlich mit Silberschorf wie unter Kapitel 7 beschrieben inokuliert. Um die Pflanzenentwicklung positiv zu beeinflussen, wurde am folgenden Tag eine Pflanzgutbeizung mit Monceren ${ }^{\circledR}$ (Wirkstoff: Pencycuron $250 \mathrm{~g} / \mathrm{l}$ ) durchgeführt. Hierdurch sollte ein Schutz der Knollen gegenüber Rhizoctonia solani gewährleistet werden. Das Mittel zeigt keine fungizide Wirkung gegen H. solani. Das behandelte Pflanzgut wurde $\mathrm{zu}$ den Versuchsstandorten transportiert und in Abhängigkeit von den Witterungsverhältnissen anschließend gelegt. Vor der 
Inokulation wurden vom Pflanzgut je Sorte 50 Knollen entnommen um einen möglichen Vorbefall durch Bonitur wie unter Kapitel 6 beschrieben zu ermitteln.

Im weiteren Versuchsverlauf wurde der Auflauf der Pflanzen im Feld überprüft. Zum Erntezeitpunkt wurde eine Kernbeerntung der zwei mittleren Reihen vorgenommen. 100 Knollen jeder Sorte von allen drei Standorten wurde direkt nach der Ernte auf Silberschorfbefall wie beschrieben bonitiert. Außerdem wurde der Befall mit $C$. coccodes überprüft. Hierbei handelt es sich ebenfalls um eine Schalenkrankheit, die möglicherweise in Konkurrenz $\mathrm{zu} H$. solani steht. Anschließend wurden aus Platzgründen nur Proben der Standorte Windeby und Groß Lüsewitz in Boxentests eingelagert und nach 8, 10 und 12 Wochen auf H. solani und C. coccodes bonitiert. Als Kontrolle wurden Knollen des Bundessortenamts ebenfalls eingelagert.

Ab Frühjahr 2003 wurden die Feldversuche an den gleichen Standorten in Deutschland wiederholt, um die Ergebnisse des Vorjahres zu untermauern. Es wurden die gleichen zwölf Sorten wie im Vorjahr von sechs Züchtungsunternehmen zur Verfügung gestellt und verwendet. Die genauen Herkünfte und Lagerbedingungen des Pflanzgutes waren unbekannt. Die Versuche wurden ebenfalls in vierfacher Wiederholung randomisiert angelegt. Hinzu kam in diesem Jahr, dass die Parzellen geteilt und jeweils nur eine Hälfte der Knollen mit $H$. solani inokuliert wurden. Die zweite Hälfte der Parzellen blieb unbehandelt, wodurch auch unter Feldbedingungen der Unterschied zwischen hohem und niedrigem Ausgangsbefallsdruck simuliert werden sollte. Die Inokulumherstellung, sowie die Inokulation wurde wie unter Kapitel 7 beschrieben durchgeführt. Pro Parzelle wurden vier Reihen mit jeweils 10 inokulierten und 10 nicht inokulierten Pflanzen gelegt. Auch im zweiten Jahr wurden die Knollen vor dem Pflanzen mit Monceren ${ }^{\circledR}$ (Wirkstoff: Pencycuron $250 \mathrm{~g} / \mathrm{l}$ ) gegen Rizoctonia solani behandelt, um Auflaufschäden vorzubeugen. Das so behandelte Pflanzgut wurde anschließend an die Versuchsstandorte geliefert, wo es bei geeigneter Witterung gepflanzt und während der Vegetationsperiode nach guter fachlicher Praxis behandelt wurde.

Vor der Behandlung der Kartoffeln wurden von jeder Probe 50 Knollen auf einen möglichen Vorbefall mit Silberschorf durch Bonitur wie unter Kapitel 6 beschrieben untersucht. Eine Rückstellprobe verblieb im Lager, um eventuelle Auflaufschwierigkeiten mit der durchgeführten Inokulation mit Silberschorf in Verbindung zu bringen. 
Im Verlaufe der Vegetationsperiode wurden Bonituren zur Auflaufrate und zur Bestandesentwicklung durchgeführt, um die Pflanzenentwicklung zu überprüfen. Zum Zeitpunkt der vollen Entwicklung der grünen oberirdischen Pflanze (EC-Stadium 65) wurden an allen drei Standorten die Pflanzenhöhen sämtlicher Parzellen gemessen, um eine mögliche Auswirkung der Inokulation auf das Pflanzenwachstum zu überprüfen. Nach Abreife zum Erntezeitpunkt wurde eine Kernbeerntung der mittleren Reihen durchgeführt. Der Ertrag pro Pflanze wurde aus technischen Gründen nur am Standort Kaltenberg ermittelt. Direkt im Anschluss wurde der Silberschorfbefall des Erntegutes ermittelt, indem von jeder Parzelle je 50 Knollen vom inokulierten und 50 Knollen vom unbehandelten Schlag einer visuellen Bonitur unterzogen wurden. C. coccodes wurde ebenfalls bonitiert. Von jeder Parzelle eines jeden Standortes wurden anschließend je 15 inokulierte als auch 15 unbehandelte Knollen in den unter Kapitel 10 beschriebenen Klimakammerversuchen (Boxentests) eingelagert. Aufgrund der langsamen Entwicklung des Pilzes konnte erst nach 10 - wöchiger Inkubation bei $20^{\circ} \mathrm{C}$ und $90 \%$ Luftfeuchte eine abschließende visuelle Bonitur durchgeführt werden.

\section{Gewächshausversuche}

\subsection{Rückstellprobe}

Die im Feld eingesetzten Knollen wurden von den verschiedenen Züchterhäusern zur Verfügung gestellt und kamen daher aus unterschiedlicher Lagerung, deren Bedingungen nicht bekannt waren. Um auszuschließen, dass andere Krankheitserreger als Silberschorf durch die Inokulation und Beizung der Knollen übertragen wurden, wurden Rückstellproben im Gewächshaus gepflanzt. Dabei wurden jeweils 6 Knollen jeder Sorte ohne jegliche Vorbehandlung in Pflanzschalen ausgepflanzt und der Auflauf täglich dokumentiert.

\subsection{Screeningversuche}

Die Feldversuche wurden im Gewächshaus reproduziert, um Faktoren wie Klima, Witterung und Boden auszuschließen. Im Gewächshaus wurden dieselben Sorten 
verwendet wie in den Feldversuchen. Das Pflanzgut wurde vom Bundessortenamt Hannover aus eigener Pflanzung zur Verfügung gestellt, um den Einfluss der Knollenherkunft und damit verbundener unterschiedlicher Lagerung auszuschließen. Dies förderte eine verbesserte Vergleichbarkeit der Sorten. Pro Sorte wurden zunächst 50 Knollen auf $H$. solani und C. coccodes bonitiert. 14 Knollen pro Sorte wurden gewaschen, mit 70 \%igem Ethanol 5 min sterilisiert und abgetrocknet. Danach wurden 7 Knollen mit einer Konidiensuspension inokuliert, 7 Knollen blieben unbehandelt. Alle 14 Knollen wurden anschließend über ein Mantisgerät mit Monceren ${ }^{\circledR}$ (Wirkstoff: Pencycuron 250 g/l) gegen Rizoctonia solani gebeizt. Nach 24 Stunden Trocknungsphase wurden pro Sorte jeweils die 7 inokulierten als auch die 7 unbehandelten Knollen in 20x20x20 cm Töpfen ausgepflanzt. Der Boden bestand aus einem 5:3 Humus/Sand Gemisch. Die Feuchtigkeit des Bodens wurde während des ganzen Versuchs mittels Tensiometer auf ca. $20 \mathrm{hPa}$ eingestellt, was $60 \%$ Wasserkapazität des beschriebenen Bodens entspricht. Dies ist optimal für das Wachstum von Kartoffeln. Dafür wurden die Tensiometerröhrchen vorher mit destilliertem Wasser gefüllt und für 2-3 Tage in destilliertem Wasser inkubiert um einen Kapilarstrom zu erzeugen. Anschließend wurden die Röhrchen in die Töpfe mit den ausgepflanzten Knollen gesteckt. Mit Hilfe des Tensiometers wurde nun der Kapilarstrom im Tonteil des Röhrchens in hPa beobachtet. Nach ca. 24 Stunden war ein gleichmäßiger Kapilarstrom zwischen Boden und Tensiometerröhrchen hergestellt und die Bodenfeuchte konnte nun mit Hilfe des Tensiometers überwacht werden.

Die Pflanzen wurden mit Tageslichtlampen mit einer Lichtstärke von 1156 lux und einem photosynthetischem Photonenfluss von $146 \mu \mathrm{mol}$ Lichtquanten pro $\mathrm{s} / \mathrm{m}^{2} 16 \mathrm{~h}$ täglich beleuchtet. Der Aufgang der Pflanzen wurde täglich kontrolliert, solange bis 100 $\%$ aller Pflanzen aufgelaufen waren. Im Verlauf der Vegetationsperiode wurden je zwei Spritzungen mit Acrobat ${ }^{\circledR}$ (Wirkstoff: Dimethomorph $500 \mathrm{~g} / \mathrm{kg}$ ) gegen Alternaria solani und Shirlan ${ }^{\circledR}$ (Wirkstoff: Fluazinam 500 g/l) gegen Phytophtora infestans sowie eine Bekämpfung gegen weiße Fliege mit Tamaron ${ }^{\circledR}$ (Wirkstoff: Methamidophos 605 g/l) durchgeführt. Die Temperatur wurde zwischen 8 und $20^{\circ} \mathrm{C}$ gehalten. Nach Abreifung der grünen Pflanze wurden die Tochterknollen geerntet und der Ertrag in $\mathrm{kg} /$ Pflanze ermittelt. Direkt nach der Ernte wurde das gesamte Erntegut auf $H$. solani und C. coccodes wie in Kapitel 6 beschrieben bonitiert und anschließend in Boxentests eingelagert. Nach 12 Wochen erfolgte die abschließende Überprüfung der Silberschorfentwicklung im Lager (vgl. Kapitel 6). 


\title{
9.3 Split-root Test zur Überprüfung des Übertragungsweges von $H$. solani
}

Zunächst wurde versucht, das Wurzelsystem von Kartoffeln zu trennen und in zwei verschiedene Töpfe mit unbehandelter und steriler Erde zu pflanzen. Dazu wurden je 3 mit Silberschorf befallene Knollen von 5 Sorten auf jeweils einem Backstein in reinem Sand in normaler Pflanztiefe gepflanzt. Die Pflanzen wurden im Gewächshaus gezogen und bis zur vollen Entwicklung der grünen Pflanze gewartet. Anschließend wurden die Pflanzen aus den Töpfen genommen und das Wurzelsystem der Pflanzen vorsichtig gewaschen bis kein Sand mehr vorhanden war. Das Wurzelsystem wurde geteilt und die in zwei miteinander verbundene Töpfe gepflanzt. Dabei war im Topf mit der Mutterknolle unbehandelte Erde, im anderen sterilisierte Erde um eine Kontamination mit schon im Boden vorhandenen Silberschorf Konidien zu vermeiden (Abb. 3). Die Pflanzen wurden bis zur natürlichen Abreife im Gewächshaus gezogen, geerntet und die Knollen auf Silberschorf überprüft (vgl. Kapitel 6).

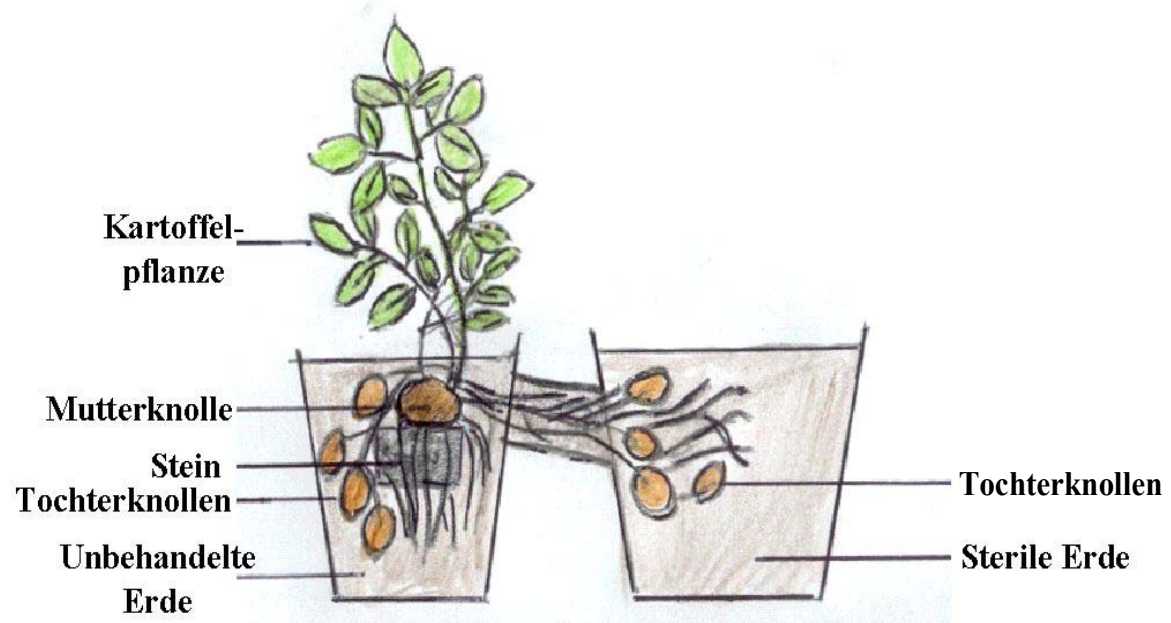

\begin{abstract}
Abbildung 3: Schema des Split-root Tests. Das Wurzelsystem einer auf einem Stein gezogenen Kartoffelpflanze wurde geteilt und in zwei miteinander verbundene Töpfe gepflanzt. Im Topf mit der Mutterknolle blieb die Erde unbehandelt, im Topf nur mit Wurzeln und Tochterknollen wurde sterile Erde verwendet. Nach Abreife wurden die Knollen geerntet und auf Silberschorf bonitiert.
\end{abstract}

\subsection{Rinnenversuch zur Überprüfung des Übertragungswegs von $\boldsymbol{H}$. solani}

Bei diesen Versuchen sollte überprüft werden, in wieweit Konidien von H. solani im Boden durch Wasser transportiert werden. Zunächst wurden Pflanzrinnen aus Plastikrohren konstruiert, die $1 \mathrm{~m}$ lang, $30 \mathrm{~cm}$ breit und $15 \mathrm{~cm}$ tief waren. In den Rinnen befanden sich im unteren Teil alle $10 \mathrm{~cm}$ Löcher zum Durchlauf des Wassers. Die 
Rinnen waren in einem Neigungswinkel von $10^{\circ}$ angebracht, um eine Fließrichtung des Wassers bestimmen zu können. Je vier Rinnen wurden mit reinem Sand, je vier weitere mit Bodenproben eines Kartoffelschlages aus der Heide befüllt. Am oberen Ende der Rinnen wurden Kartoffelknollen einer anfälligen Sorte gepflanzt. Vorher wurden je 2 der Knollen pro Sandboden und Heideboden mit H. solani inokuliert, jeweils 2 Knollen blieben unbehandelt Abb. 4).

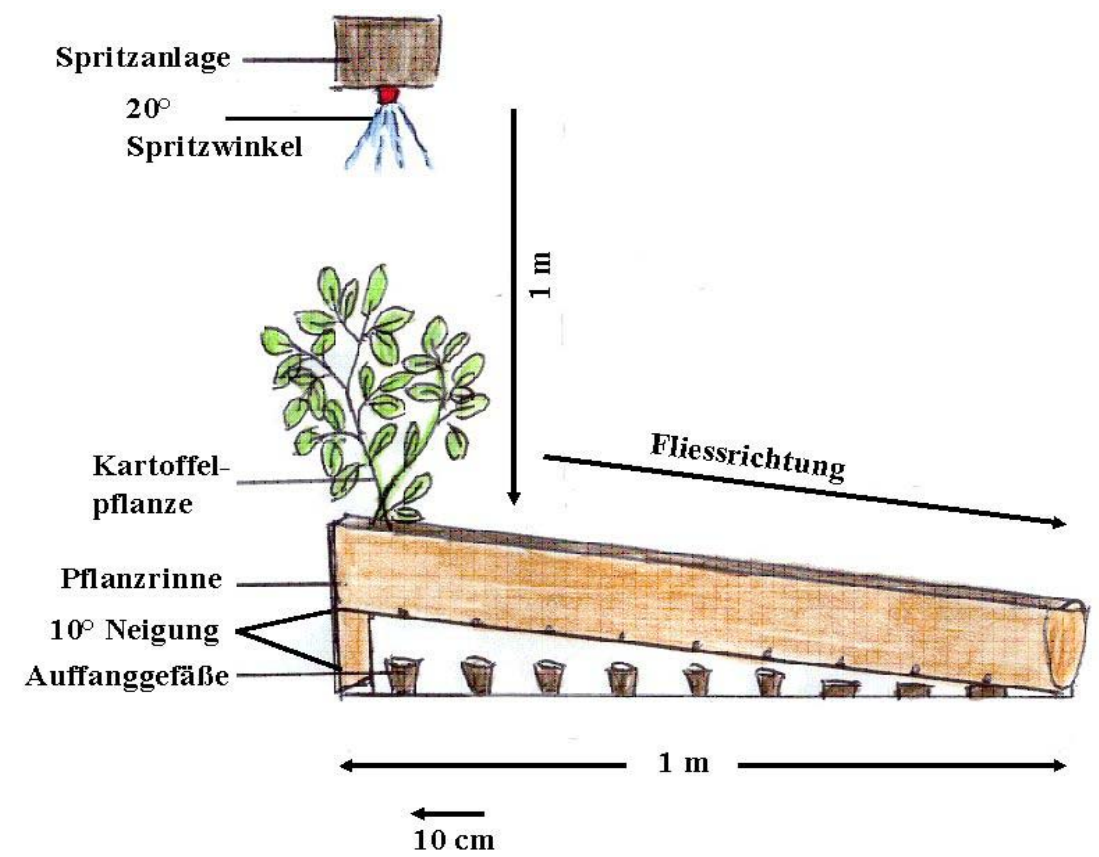

Abbildung 4: Rinnversuch zur Überprüfung des Transports von $H$. solani Konidien im Bodenwasser. Am oberen Ende einer $1 \mathrm{~m}$ langen Pflanzrinne, die in einem $10^{\circ}$ Neigungswinkel angebracht war, wurden Knollen ausgepflanzt. Alle $10 \mathrm{~cm}$ waren Löcher in den Rinnen angebracht zum Durchlauf des Gieswassers. Unter den Löchern wurden Auffanggefäße für das durchlaufende Wasser platziert. $1 \mathrm{~m}$ oberhalb der Pflanze war eine Spritzanlage angebracht, mit der Regenereignisse simuliert werden konnten. Der Spritzwinkel der Düse wurde möglichst gering gehalten um nur die Pflanzrinne zu bewässern..

Die Pflanzen wurden mit Tageslichtlampen wie in Kapitel 9.216 h täglich beleuchtet. Die Temperatur wurde zwischen $10-16^{\circ} \mathrm{C}$ gehalten. Der Aufgang der Pflanzen wurde täglich kontrolliert. In ca. $1 \mathrm{~m}$ Höhe über den gepflanzten Knollen wurde eine Spritzanlage mit speziellen Flachstrahldüsen mit $20^{\circ}$ Spritzwinkel installiert. Dadurch sollte eine ausschließliche Bewässerung der Rinnen gewährleistet werden. Die Spritzanlage wurde an eine Hochdruckspritze angeschlossen und ausgelitert. Nach Auflauf der Pflanzen wurden die Rinnen mit Hilfe der Spritzanlage mit 21 Wasser zweimal in der Woche pro Rinne bewässert und das Durchlaufwasser an den verschiedenen Löchern unterhalb der Pflanzrinnen separat aufgefangen. Das aufgefangene Wasser wurde in $15 \mathrm{ml}$ Reaktionsröhrchen überführt und kurz zentrifugiert um die meisten Bodenpartikel zu sedimentieren. Vom Überstand wurden 
Proben entnommen und in einer Fuchs - Rosenthal Zählkammer auf $H$. solani Konidien untersucht.

\section{Klimakammerversuche zur Untersuchung der Befallsentwicklung im Lager (Boxentest)}

Casanet-Gitter mit einer Gitterweite von 1x1cm wurde auf eine Größe von 22,5x21,5 $\mathrm{cm}$ zugeschnitten. Die Kanten der 22,5 cm langen Seite wurden um $90^{\circ}$ geknickt um eine Flächengröße von $21,5 \times 21,5 \mathrm{~cm}$ mit einer Fußhöhe von $1 \mathrm{~cm} \mathrm{zu}$ erhalten.

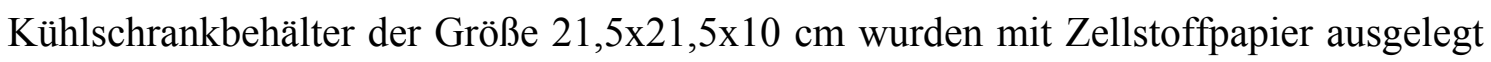
und mit dem zugeschnittenen Casanet - Gitter ausgestattet. Anschließend wurde das Zellstoffpapier bewässert, was im Verlauf des Versuches mehrmals wiederholt wurde um eine ständige Feuchtigkeit im Behälter zu gewährleisten. Pro Kiste wurden anschließend 5-8 Kartoffelknollen auf dem Casanet - Gitter platziert um einen direkten Kontakt zum Wasser zu vermeiden. Die Kisten wurden luftundurchlässig verschlossen und in einer Klimakammer bei $20^{\circ} \mathrm{C}$ im Dunkeln inkubiert, um eine Luftfeuchtigkeit von $90 \%$ zu erzeugen. Nach 8, 10 und 12 Wochen erfolgten Bonituren der eingelagerten Knollen auf den Befall mit Silberschorf und C. coccodes (vgl. Kapitel 6).

Bei den Boxentests der im Feld geernteten Knollen wurden pro Versuchsglied in je fünf Kisten je fünf Knollen eingelagert und der Befall nach 10 Wochen begutachtet. Zuvor wurden die Knollen von Erde und Staub gereinigt. Bei allen im Gewächshaus durchgeführten Versuchen wurden anschließend immer alle geernteten Knollen in entsprechend vielen Kisten eingelagert.

\section{Bodensuppressivitätstest}

Um den Einfluss des Bodens auf die Keimfähigkeit von $H$. solani Konidien und damit dessen Einfluss auf die Übertragung des Pilzes von Mutter- auf Tochterknollen zu überprüfen, wurde ein Bodensuppressivitätstest durchgeführt. Zunächst wurde eine wässrige Konidiensuspension von $H$. solani hergestellt, welche möglichst frei von Myzel war. In je zwei Glaspetrischalen wurden anschließend ca. 30 g Frischboden verschiedener Herkunft eingewogen. Jeweils eine Petrischale mit dem Boden einer 
Herkunft wurde autoklaviert, der andere blieb unbehandelt. Daraufhin wurde der Boden in den Schalen vorsichtig mit Leitungswasser beträufelt bis er sich mit einem Glasspatel zu einer speckig glänzenden Oberfläche glatt ziehen ließ. Die Konidiensuspension wurde im Kleinexikator auf eine Celluloseacetat-Membran gesaugt, wobei die Konidiensuspension nicht zu dicht gewählt werden durfte. Die Membranfilter wurden mit der Schere geviertelt und je 2 Segmente pro Erdschale flach auf den Boden aufgelegt, um für guten Diffusionskontakt zu sorgen. Die Schalen wurden ca. 10 Tage bei ca. $20^{\circ} \mathrm{C}$ im Dunkeln inkubiert. Nach Inkubation wurden die Membranen mit Calcofluor gefärbt und eine mikroskopische Beurteilung der Keimrate in \% durchgeführt.

\subsection{Bodensuppressivitätstest mit Kartoffelwasser}

Um zu überprüfen, ob die Anwesenheit verschiedener Kartoffelknollen wiederum einen positiven Effekt auf die Keimung von $H$. solani Konidien hat, und somit die Suppression der Böden aufheben kann, wurde der Suppressivitätstest folgendermaßen modifiziert. Zunächst wurden 5 Knollen der in Feld- und Gewächshaus verwendeten Sorten gewaschen und in $96 \%$ igem Ethanol sterilisiert. Anschließend wurden sie in autoklaviertes Wasser gelegt und für 1, 3 und 5 Tage bei $20^{\circ} \mathrm{C}$ im Dunkeln inkubiert. Die Wassermenge pro Sorte entsprach dem Gewicht der 5 verwendeten Knollen. Nach 1, 3 bzw. 5 Tagen wurde der oben beschriebene Bodensuppressivitätstest mit dem Boden nur einer Herkunft durchgeführt, wobei zum Anwässern der Bodenproben nun das Wasser der eingelegten Kartoffelknollen verwendet wurde. Zusätzlich wurde eine Probe mit Leitungswasser als Kontrolle mitgeführt. Nach 10 Tagen erfolgte die Auswertung wie in Kapitel 11 beschrieben.

\subsection{Enzymatische Zuckeranalyse}

Da Zucker die Suppressivität eines Bodens teilweise aufheben kann, wurde der Saccharose-, Glucose- und Fructosegehalt des Wassers in dem die verschiedenen Kartoffelsorten eingelagert waren getestet. Dabei wurde der D-Glucose Gehalt vor und nach enzymatischer Hydrolyse der Saccharose bestimmt. Abschließend wurde noch der 
Gehalt an D - Fructose gemessen. Das Prinzip des Tests war wie folgt: das Enzym Hexokinase katalysiert bei $\mathrm{pH}$ 7,6 die Phosphorylierung von D- Glucose mit Adenosin5 '-triphosphat (ATP) unter gleichzeitiger Bildung von Adenosin-5'-diphosphat (ADP). Das entstandene D-Glucose-6-phosphat wird von Nicotinamid-adenin-dinucleotidphosphat (NADP) in Gegenwart von Glucose-6-phosphat-Dehydrogenase spezifisch zu D-Gluconat-6-phosphat (G-6-P) oxidiert, wobei reduziertes Nicotinamid-adenindinucleotid-phosphat (NADPH) entsteht. Die während dieser Reaktion gebildete NADPH-Menge ist der D-Glucose Menge entsprechend und wird auf Grund ihrer Absorption bei $340 \mathrm{~nm}$ bestimmt. (TRAUTNER 1969, FUCHS \& WRETLING 1979).

Hexokinase katalysiert auch die Phosphorylierung von D-Fructose mit ATP zu DFructose-6-phosphat (F-6-P). Nach Ablauf dieser Reaktion wird F-6-P durch Phosphoglucose-Isomerase in G-6-P umgewandelt. G-6-P wiederum reagiert wie beschrieben mit NADP unter Bildung von D-Glucose-6-phosphat und NADPH. Auch dabei ist NADPH die Messgröße. Die nun gebildete NADPH Menge ist äquivalent zur D-Fructose Menge (TrautNer 1969, FuCHS \& WRETLING 1979).

Saccharose wird durch das Enzym ß-Fructosidase (Invertase) bei pH 4,6 zu D-Glucose und D-Fructose hydrolysiert. Anschließend folgt die D-Glucose Bestimmung wie beschrieben. Aus der Differenz der D-Glucose Konzentration vor und nach enzymatischer Inversion wird der Gehalt an Saccharose berechnet (TRAUTNER 1969, FUCHS \& WRETLING 1979).

Gemessen wurde die Extinktion bei $340 \mathrm{~nm}$ in einer Glasküvette mit $1 \mathrm{~cm}$ Schichtdicke. Die Temperatur lag zwischen $20^{\circ} \mathrm{C}$ und $25^{\circ} \mathrm{C}$. Es wurde das Reaktionskit für Saccherose/D-Glucose/D-Fructose der Firma R-Biopharm Dabei wurden vier Reaktionen nach dem Schema von Tab. 2 durchgeführt.

Tabelle 2: Versuchsdurchführung des enzymatischen Zuckertests.

\begin{tabular}{|c|c|c|c|c|}
\hline In Küvetten pipetieren & $\begin{array}{c}\text { Leerwert } \\
\text { Saccharose } \\
\text { Probe }\end{array}$ & $\begin{array}{l}\text { Saccharose } \\
\text { Probe }\end{array}$ & \begin{tabular}{|c|} 
Leerwert \\
D - Glucose/D \\
- Fructose \\
Probe \\
\end{tabular} & $\begin{array}{c}\text { D - Glucose } / \\
\text { D - Fructose } \\
\text { Probe }\end{array}$ \\
\hline $\begin{array}{l}\text { Lösung 1: Lyophilisat } \\
\text { Probelösung }\end{array}$ & $\begin{array}{c}0,200 \mathrm{ml} \\
----\end{array}$ & $\begin{array}{l}0,200 \mathrm{ml} \\
0,100 \mathrm{ml}\end{array}$ & $\begin{array}{l}---- \\
----\end{array}$ & 0,---- \\
\hline \multicolumn{5}{|c|}{ Mischen, $15 \mathrm{~min}$ bei $20-25^{\circ} \mathrm{C}$ stehen lassen. Zugabe von } \\
\hline $\begin{array}{l}\text { Lösung 2: NADP und ATP } \\
\text { Bidest. Wasser }\end{array}$ & $\begin{array}{l}1,000 \mathrm{ml} \\
1,800 \mathrm{ml}\end{array}$ & $\begin{array}{l}1,000 \mathrm{ml} \\
1,700 \mathrm{ml}\end{array}$ & $\begin{array}{l}1,000 \mathrm{ml} \\
2,000 \mathrm{ml}\end{array}$ & $\begin{array}{l}1,000 \mathrm{ml} \\
1,900 \mathrm{ml}\end{array}$ \\
\hline
\end{tabular}




\begin{tabular}{|c|c|c|c|c|}
\hline $\begin{array}{c}\text { Lösung 3: } \\
\text { Hexokinase/Dehydrogenase }\end{array}$ & $0,020 \mathrm{ml}$ & $0,020 \mathrm{ml}$ & $0,020 \mathrm{ml}$ & $0,020 \mathrm{ml}$ \\
\hline \multicolumn{5}{|c|}{$\begin{array}{l}\text { Mischen, Stillstand der Reaktion abwarten (ca. } 10-15 \text { min) und Extinktionen der Lösunger } \\
\text { messen }\left(E_{2}\right) \text {. }\end{array}$} \\
\hline Lösung 4: Isomerase & ----- & ----- & $0,020 \mathrm{ml}$ & $0,020 \mathrm{ml}$ \\
\hline
\end{tabular}

Zur Bestimmung der D - Glucose und der Saccharose wurden folgende Berechnungen durchgeführt: Für die Leerwerte und die Proben wurde die Extinktionsdifferenz errechnet $\left(E_{2}-E_{1}\right)$ und die der Leerwerte von den dazugehörigen Proben abgezogen:

$$
\Delta \mathrm{E}=\left(\mathrm{E}_{2}-\mathrm{E}_{1}\right)_{\text {Probe }}-\left(\mathrm{E}_{2}-\mathrm{E}_{1}\right)_{\text {Leerwert }}
$$

Die Differenz von $\Delta \mathrm{E}_{\mathrm{Gesamt}}$ (aus Saccharose Probe) und $\Delta \mathrm{E}_{\mathrm{D}}$ - Glucose (aus $\mathrm{D}-$ Glucose Probe) ergibt $\Delta \mathrm{E}_{\text {Saccharose }}$.

Für die Berechnung der D - Fructose gilt: Zunächst wurde für den Leerwert und die Probe (D - Glucose/D - Fructose Probe) die Extinktionsdifferenz $\left(\mathrm{E}_{3}-\mathrm{E}_{2}\right)$ bestimmt. Die Extinktionsdifferenz des Leerwertes wurde von der Extinktionsdifferenz der Probe abgezogen, wodurch man $\Delta \mathrm{E}_{\mathrm{D}}$ - Fructose erhält. Für die Berechnung der Konzentrationen in den untersuchten Proben gilt nun folgende allgemeine Berechnungsformel:

$$
\mathrm{c}=\left(\left(\mathrm{V}^{*} \mathrm{MG}\right) /\left(\varepsilon^{*} \mathrm{~d}^{*} \mathrm{v}^{*} 1000\right)\right) * \Delta \mathrm{E}(\mathrm{g} / \mathrm{l})
$$

$\mathrm{V}=$ Testvolumen $(\mathrm{ml})$

$\mathrm{v}=$ Probenvolumen $(\mathrm{ml})$

$\mathrm{MG}=$ Molekulargewicht der zu bestimmenden Substanz (g/mol):

Saccharose $=342,3 \mathrm{~g} / \mathrm{mol}$

$\mathrm{D}-$ Glucose $=180,16 \mathrm{~g} / \mathrm{mol}$

$\mathrm{D}-$ Fructose $=180,16 \mathrm{~g} / \mathrm{mol}$

$\mathrm{d}=$ Schichtdicke $(\mathrm{cm})$

$\varepsilon=$ Extinktionskoeffizient von NADPH bei $340 \mathrm{~nm}=6,3\left(1 * \mathrm{mmol}^{-1} * \mathrm{~cm}^{-1}\right)$

\section{Anzucht von Meristemkartoffeln}

Um befallsfreie Kartoffelknollen zu erhalten, wurden sogenannte Meristemkartoffeln gezogen. Das Blattmeristem von Kartoffelpflanzen wurde vorsichtig abgeschnitten und mit $70 \%$ Ethanol sterilisiert. Anschließend wurde die Probe auf Wasseragar unter sterilen Bedingungen aufgelegt und bei Raumtemperatur bei Tageslicht für $16 \mathrm{~h}$ am Tag für ca. 2 Wochen inkubiert. Die so gewachsenen Pflanzen durften nicht direktem 
Sonnenlicht ausgesetzt werden, da die Pflanzen so keinen ausreichenden Schutz gegen die Bestrahlung mit UV-Licht ausgebildet konnten.

\section{Vermessung der Periderm-Cortexdicke mit Hilfe der computerbasierten Bildanalyse}

Da $H$. solani ausschließlich die Schale (Periderm-Cortexschicht) von Kartoffelknollen befällt, wurde auch die physikalische Schalenbeschaffenheit überprüft. Um einen Zusammenhang zwischen Periderm-Cortexdicke und Anfälligkeit der Sorten untersuchen $\mathrm{zu}$ können, wurde ein Bildbearbeitungsprogramm zur schnellen Vermessung der Schale optimiert und eingesetzt. Nach Photographieren eines mit Hilfe des Mikrotomschneiders hergestellten Dünnschnittes der Schalenregion der Kartoffelknolle unter dem Binokular (Abb.5A) wurde anhand der unterschiedlichen Graustufen zwischen Periderm-Cortex und Lagerungsparenchym die Schale (welche der Periderm- und Cortexschicht entspricht) abgegrenzt (Abb. 5B). Die abgegrenzte Teilfläche wurde anschließend an zahlreichen Stellen vom Computer vermessen (Abb. $5 \mathrm{C})$.

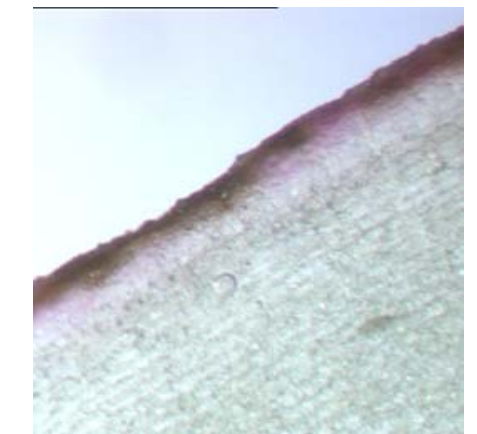

A einer Kartoffelschale unter dem Binokular bei 30x Vergrößerung

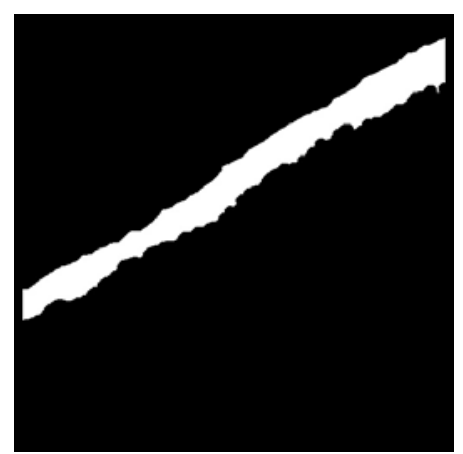

B

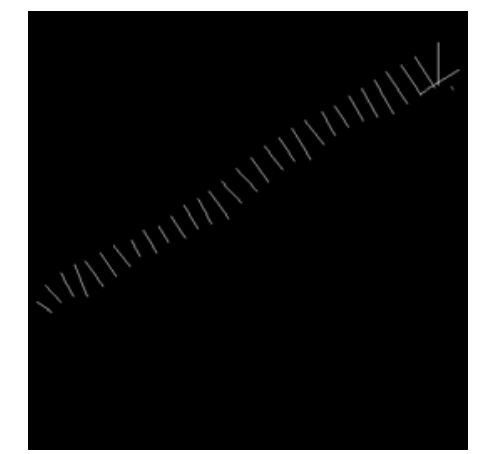

C

Abb. 5C: Vermessung des Schalenregion anhand der Computers der als Schale unterschiedlichen Graustufen definierten Region von Bild A.

Dies wurde mit allen im Feld und Gewächshaus getesteten Sorten durchgeführt, wobei von jeweils 5 Knollen jeder Sorte 10 Dünnschnitte hergestellt und vermessen wurden. Aus diesen Messdaten wurden für jede Kartoffelsorte Mittelwerte gebildet und abschließend eine Regression zwischen den in Feld und Gewächshaus ermittelten Daten des Anfälligkeitsverhaltens jeder Sorte und der dazugehörigen Periderm-Cortexdicke errechnet. Die Bildanalyse sollte ebenfalls zur Bonitur befallener Knollen eingesetzt 
werden, um die langwierige und arbeitsintensive visuelle Bonitur zu vereinfachen und $\mathrm{zu}$ beschleunigen. Dies erwies sich jedoch nach genauerer Untersuchung als nicht durchführbar, da die exakte Oberfläche der einzelnen Knolle von normalen Bildbearbeitungsprogrammen nicht erfasst werden kann.

\section{4 Überprüfung der Schalenbeschaffenheit mittels Wägetest}

Da neben der Schalendicke auch die Schalenbeschaffenheit (rauhschalig, glattschalig) eine Rolle spielen kann, wurde diese in einem Wägetest überprüft. Dazu wurden 20 Knollen jeder Sorte gründlich unter fließendem Wasser gereinigt und anschließend mit Ethanol gewaschen. Danach wurden sie über Nacht getrocknet. Am nächsten Tag wurden die Knollen zunächst gewogen und anschließend in ein Wasserbad getaucht und wiederum gewogen. Die Differenz wurde errechnet und die Knollen wiederum getrocknet. Die trockenen Knollen wurden wieder gewogen und danach in einem Staubbad gewälzt. Abschließend wurden die Knollen wiederum gewogen und die Differenz errechnet. Der Staub stammte aus getrocknetem Boden aus der Heide. Anhand des anhaftenden Wassers bzw. der Erde wurde auf die Rauh- bzw. Glattschaligkeit geschlossen. Abschließend wurde eine Regression zwischen Schalenbeschaffenheit und Anfälligkeit der Sorten errechnet.

\section{Mikroskopische Untersuchungen}

Um zu untersuchen, wie und wie tief der Pilz in das Pflanzengewebe der Kartoffelknolle eindringt, wurden mikroskopische Untersuchungen durchgeführt. Dazu wurden Mikrotomschnitte an mit H. solani befallenen Kartoffelknollen hergestellt. Um den Pilz vom Pflanzengewebe abzuheben, wurden verschiedene Färbemethoden angewendet und die Gewebeprobe anschließend unter dem Mikroskop untersucht. Maßgeblich wurde die Comassie-Brilliant-Blau-Färbung als auch die Färbung mit dem Fluoreszenzfarbstoff Calcofluor angewendet. Für die Comassie-Brilliant-Blau Färbung wurden die Proben in Ethanol/Chloroform 75/25 + 0,15 \% Trichloressigsäure (ACE) fixiert und aufbewahrt. Die Proben wurden anschließend gründlich mit destilliertem Wasser gespült und $2-3 \mathrm{~min}$ in Comassie-Brilliant-Blau Färbelösung $(0,6 \%$ 
Comassie-Brilliant-Blau R-250 in $99 \%$ Methanol 1:1 gemischt mit $15 \%$ iger, wässriger Lösung von Trichloressigsäure) gefärbt. Die Färbelösung wurde abgegossen und die Probe wiederum gründlich mit destilliertem Wasser gewaschen. Die Proben wurden in Eisessig - Glycerin $\left(5 \% / 20 \%\right.$ in $\left.\mathrm{H}_{2} \mathrm{O}\right)$ aufgenommen und mikroskopiert.

Für die Färbung mit Calcofluor wurden die Proben zunächst gründlich mit A. dest. gespült. Anschließend wurden die gewaschenen Proben $30 \mathrm{~min}$ in $0,1 \mathrm{M}$ Tris- $\mathrm{HCl}$ pH 8 inkubiert. Nach dem Waschen in destilliertem Wasser für 4x10 min wurden die Proben $5 \mathrm{~min}$ in $0,1 \%$ Calcofluorlösung gefärbt. Es folgte ein weiterer Waschschritt in $25 \%$ Glycerin für 30 min. Abschließend wurden die Proben in $25 \%$ Glycerin unter dem Fluoreszenzmikroskop betrachtet. Bei den Bodensuppressivitätstests wurden die gesamten Celluloseacetat-Membranen mit den darauf gesaugten Konidien wie oben beschrieben mit Calcofluor angefärbt. Dabei wurde bei diesen aufgrund der empfindlichen Membran das Waschen mit Tris- $\mathrm{HCl}$ weggelassen und auch das Waschen mit Glycerin auf 5 min beschränkt.

\section{Analyse von Phytoalexinen mittels Dünnschichtchromatographie (DC), Bioassay und Hochdruckflüssigkeitschromatographie (HPLC)}

\subsection{Extraktion der Phytoalexine aus Kartoffelschalen}

Da es sich bei Silberschorf um eine Krankheit handelt, die ausschließlich die Kartoffelschale befällt, wurde die Ursache der Sortenunterschiede in deren Zusammensetzung gesucht. Zunächst wurde die mögliche Anwesenheit von Phytoalexinen überprüft.

Dazu wurden jeweils $1 \mathrm{~g}$ gesunde und mit $H$. solani befallenen Schalenprobe in $15 \mathrm{ml}$ $\mathrm{H}_{2} \mathrm{O}$ aufgenommen und mit dem Ultrathurrax zerkleinert. Die Wasserphase wurde mit $15 \mathrm{ml}$ Ethylacetat überschichtet und gut geschüttelt. Anschließend wurden die Proben 10 min bei $5000 \mathrm{rpm}$ zentrifugiert. Die Ethylacetatphase wurde abgenommen und über die Wasserphase erneut $15 \mathrm{ml}$ Ethylacetat geschichtet und geschüttelt. Es folgte wiederum eine Zentrifugation (10 min, $5000 \mathrm{rpm})$. Die Ethylacetatphasen wurden vereinigt und bei $-20^{\circ} \mathrm{C}$ eingelagert. $5 \mathrm{ml}$ der Ethylacetatphase wurde unter Stickstoffstrom eingedampft und in $100 \mu 100 \%$ Ethanol aufgenommen. 


\subsection{Auftrennung der Proben mittels DC}

Phytoalexine können anhand ihrer molekularen Eigenschaften in einer Trennmatrix, in diesem Fall Kieselgel, durch Verwendung geeigneter Laufmittel getrennt werden. Nach dem Lauf kann man verschiedene Fraktionen auf der DC-Platte unter UV-Licht sichtbar machen. Zunächst wurden die DC-Platten $30 \mathrm{~min}$ bei $100^{\circ} \mathrm{C}$ im Trockenschrank vorkonditioniert. Währenddessen wurden 2 Trennkammern vorbereitet mit jeweils $100 \mathrm{ml}$ Laufmittel. Kammer 1 wurde mit Aceton gefüllt, Kammer 2 nach dem Verfahren von SAKAI (1979) mit einem Gemisch aus Cyclohexan und Ethylacetat (1:1). Hieraus sollte sich eine Füllhöhe von $0,5 \mathrm{~cm}$ ergeben. Die DC-Platten wurden auf Heizplatten mit $40^{\circ} \mathrm{C}$ gelegt und $20 \mu \mathrm{l}$ der aufzutrennenden Proben $2 \mathrm{~cm}$ vom unteren Plattenrand in $2 \mathrm{~cm}$ Abständen aufgetragen. Danach wurden die Platten zur Probenfokussierung in die mit Aceton befüllte Trennkammer eingestellt. Nachdem die Laufmittelfront ca. $2 \mathrm{~cm}$ Laufweite errecht hatte, wurde der Lauf beendet und die Platten bei $40^{\circ} \mathrm{C} 10$ min rückgetrocknet. Nach vollständiger Rücktrocknung wurden die Platten in die Kammer mit Cyclohexan/Ethylacetat gestellt und die Trennung so lange fortgesetzt, bis die Laufmittelfront den oberen Rand der DC-Platte erreicht hatte. Die Platten wurden der Kammer entnommen und die Laufmittelfront mit einem Bleistift markiert. Die Lösungsmittel wurden ca. 30 min im Abzug abgedampft. Abschließend wurde mit den DC - Platten ein Bioassay durchgeführt, um die pathogenrelevanten Inhaltsstoffe zu überprüfen.

\subsection{Bioassay}

Um die fungizide Wirkung der gefundenen Substanzen zu überprüfen wurde ein Bioassay durchgeführt. Da $H$. solani viel zu langsam wächst und daher für einen Bioassay nicht geeignet ist, wurde hierfür eine Cladiosporium sp. - Sporensuspension hergestellt. Hierzu wurden gut sporulierende Kulturen mit $50 \mathrm{ml} \mathrm{Malz-Pepton-Medium}$ überschichtet und die Sporen mit Hilfe eines Objektträgers abgekratzt. Die Nährlösung wurde durch einen Nylonfilter in einen Erlenmeyerkolben abgegossen. Eine Feuchtekammer und ein Sprühgerät wurden mit 70 \% Ethanol gereinigt. Anschließend wurden die vorher beschriebenen, ausgewerteten DC-Platten mit Hilfe einer an Druckluft angeschlossenen Sprühvorrichtung mit der Sporensuspension besprüht, 
solange bis die Platten samtig glänzten. Die Platten wurden in eine mit etwas Wasser gefüllte Feuchtekammer gegeben und 3-4 Tage bei RT inkubiert. Anschließend wurde das Wachstum des Pilzes auf den Platten überprüft und mittels Kamera dokumentiert.

\subsection{Analyse der Proben mittels HPLC}

Aus den DC-Platten wurden unter UV-Licht die mit Bleistift markierten Hauptbanden von der Platte gekratzt und in ein 1,5 ml Reaktionsgefäß überführt. Die Proben wurden mit $500 \mu \mathrm{l}$ Aceton versetzt und $10 \mathrm{~min}$ geschüttelt. Anschließend erfolgte eine Zentrifugation $\left(10 \mathrm{~min}, 15000 \mathrm{rpm}, 4^{\circ} \mathrm{C}\right)$ und der Überstand wurde in ein neues 1,5 ml Reaktionsgefäß überführt. Dies wurde wiederholt und die Proben schließlich unter einem Stickstoffstrom eingedampft. Der Niederschlag wurde in $50 \mu$ l absolutem Ethanol aufgenommen und für die HPLC - Analysen verwendet.

Die Trennung auf der HPLC - Anlage wurde in einer Synergi 4 $\mu$ HydroRP 80A, 250 x 4,6 mm Säule bei Raumtemperatur durchgeführt. Mit Hilfe des Autosamplers wurden $20 \mu \mathrm{l}$ der Probe in 60-minütigem Intervall eingespritzt, um eine optimale Auftrennung $\mathrm{zu}$ erreichen. Es wurden die Flussraten von $0,75 \mathrm{ml} / \mathrm{min}$ verwendet. Bei einer Wellenlänge von $218 \mathrm{~nm}$ erfolgte die Detektion im Photometer.

Die Trennung erfolgte in einem Gradienten mit einem Gemisch aus Wasser und Cyclohexan/Ethylacetat. Der Laufmittelgradient wurde variiert, am optimalsten stellte sich der in Tabelle 5 beschriebene dar.

Tabelle 5: Laufmittelgradient für die chromatographische Trennung von Phytoalexinen durch HPLC

\begin{tabular}{|l|l|l|}
\hline $\begin{array}{l}\text { Cyclohexan/Ethylacetat } \\
(1: 1)\end{array}$ & Wasser & Zeitintervall (min) \\
\hline 40 & 60 & 00.00 \\
\hline 40 & 60 & 02.00 \\
\hline 50 & 50 & 08.00 \\
\hline 90 & 10 & 24.00 \\
\hline 100 & 0 & 10.00 \\
\hline 40 & 60 & 16.00 \\
\hline
\end{tabular}


17 Untersuchungen phenolischer Verbindungen in Kartoffelschalen

\subsection{Aufbereitung des Schalenmaterials mit Thioglykolsäure und quantitative Analyse}

Bei der Umsetzung aufgereinigter Zellwände mit Thioglykolsäure bilden sich alkalilösliche, säureunlösliche Lignothioglykolsäurekomplexe. Die phenolischen Anteile solcher Komplexe können bei $380 \mathrm{~nm}$ photometrisch gemessen werden und stellen so ein Maß für den Ligningehalt dar. Die so durchgeführte Bestimmung des Liningehaltes wurde nach modifizierter Methode von MENDEN (1995) nach MOERSCHBACHER et al. (1989) durchgeführt. Das Verfahren beruht auf den Versuchsvorschriften von HAMMERSCHMIDT et al. (1984).

Zunächst wurden Knollen gekocht und anschließend die Schale (Periderm und Cortex) vom Lagerungsparenchym gepellt. Die Schale wurde im Trockenschrank bei $80^{\circ} \mathrm{C}$ über Nacht getrocknet und in einer Kugelmühle für zweimal je 5 min zerkleinert $(100 \%$ Leistung). $7 \mathrm{mg}$ getrocknete und in der Kugelmühle pulverisierte Kartoffelschale wurden in ein Hydrolysegefäß eingewogen, mit $5 \mathrm{ml} 2 \mathrm{~N} \mathrm{HCl}$ und $0,2 \mathrm{ml}$ Thioglycolsäure versetzt und $4 \mathrm{~h}$ bei $100{ }^{\circ} \mathrm{C}$ im Rückflusskühler inkubiert. Die abgekühlten Proben wurden zentrifugiert (2000xg, $10 \mathrm{~min}$ ), das Pellet zweimal mit je 5 $\mathrm{ml}$ destilliertem Wasser gewaschen und danach $17 \mathrm{~h}$ bei Raumtemperatur in $5 \mathrm{ml} 0,5 \mathrm{M}$ $\mathrm{NaOH}$ inkubiert. Die Lignothioglycolsäurekomplexe gingen dabei in Lösung. Unlösliche Zellwandreste wurden wie beschrieben abzentrifugiert (s.o.) und das Pellet zweimal mit je 2,5 ml dest. Wasser gewaschen. Die vereinigten Überstände wurden mit $6 \mathrm{~N} \mathrm{HCl}$ auf $\mathrm{pH}<3,0$ angesäuert und zur Kristallisation der Lignothioglykolsäurekomplexe ca. $17 \mathrm{~h}$ bei $4{ }^{\circ} \mathrm{C}$ inkubiert. Die ausgefallenen

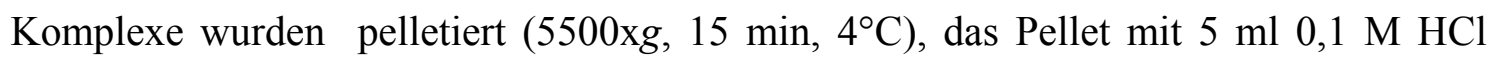
gewaschen und danach in $1 \mathrm{ml} 0,5 \mathrm{M} \mathrm{NaOH}$ resuspendiert. Durch Sterilfiltration wurden Schwebteilchen abgetrennt und anschließend die Extinktion einer 1:10 Verdünnung des Überstandes bei $380 \mathrm{~nm}$ im Photometer gemessen. Eine Eichung der Methode wurde von MENDEN 1995 versucht, erschien aber letztlich nicht sinnvoll. Die Ergebnisse werden daher, wie in der Literatur üblich, in Millieextinktionseinheiten pro eingesetzte Zellwandprobe angegeben ( $\mathrm{mEx} / \mathrm{mg} \mathrm{ZW})$. Mit dieser Methode können somit nur relative Aussagen über den Ligningehalt gemacht werden. Für den Vergleich der Kartoffelsorten untereinander reicht dies aus. 


\subsection{Aufbereitung des Schalenmaterials mittels alkalischer Hydrolyse für die qualitative Analyse mit HPLC}

Zunächst wurden Knollen gekocht und anschließend die Schale (Periderm und Cortex) vom Lagerungsparenchym gepellt. Die Schale wurde im Trockenschrank bei $80^{\circ} \mathrm{C}$ über Nacht getrocknet. Das im Trockenschrank getrocknete Schalenmaterial wurde in einer Kugelmühle für zweimal je 5 min zerkleinert (100\% Leistung), wobei zwischen den Mahlgängen die Zugabe von $1 \mathrm{ml}$ Methanol erfolgte. Das zerkleinerte Material wurde anschließend in kochendem Methanol aufgenommen und in Anlehnung an KICINSKI et al. (1988) 2 min m Ultraschallbad behandelt. Nach Zentrifugation bei 40000xg erfolgte durch vorsichtiges Dekantieren eine Fraktionierung in Überstand und Pellet.

Die alkalische Hydrolyse der Pelletfraktion erfolgte mit 0,5 N NaOH über $16 \mathrm{~h}$ bei ständiger Bewegung der Probe, $\mathrm{O}_{2}-$ Ausschluss und bei Dunkelheit. Anschließend wurden die festen Bestandteile des Schalenmaterials über Glasfilter abgetrennt. Nach Ansäuern auf $\mathrm{pH} 2,5$ mit $4 \mathrm{~N} \mathrm{HCl}$ und Zusatz von $600 \mathrm{mg} \mathrm{NaCl}$ erfolgten zwei Extraktionen gebundener Phenolcarbonsäuren bzw. Aldehyde mit Essigsäureethylester. Zur Trennung der Phasen wurde bei 1200xg zentrifugiert. Nach Eindampfen der Ethylacetatphase wurde das Hydrolysat in Anlehnung an KICINSKI et al. (1988) in Methanol / 5 \% Ameisensäure (7:93) aufgenommen und p-Anissäure als interner Standard zur Quantifizierung (HARTLEY, 1987) zugegeben. Diese Extrakte wurden anschließend in der HPLC auf ihren Gehalt an phenolischen Verbindungen gemessen.

Für die alkalische Hydrolyse der Fraktion ungebundener phenolischer Verbindungen

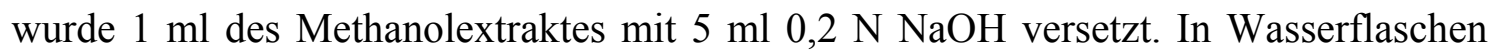
erfolgte die 20 - stündige Hydrolyse, wie zuvor beschrieben. Anschließend wurde die Probe auf $\mathrm{pH} 4$ angesäuert, $300 \mathrm{mg} \mathrm{NaCl}$ zugegeben und zweimal mit Essigsäureethylester in Scheidetrichtern extrahiert. Die weitere Aufbereitung erfolgte wie bei den gebundenen Verbindungen.

Zur Analyse des nicht-hydrolysierten Extrakts wurde $1 \mathrm{ml}$ Methanolextrakt (Überstand) mit $5 \mathrm{ml}$ bidest. $\mathrm{H}_{2} \mathrm{O}$ versetzt und wie beschrieben aufgearbeitet. 


\subsection{Qualitative Analyse von Phenolcarbonsäuren bzw. Aldehyden mit HPLC}

Die Trennung auf der HPLC - Anlage wurde in einer Synergi HydroRP-18 (250 x 4,6 mm) Säule bei Raumtemperatur durchgeführt. Mit Hilfe des Autosamplers wurden $20 \mu 1$ der Probe in verschiedenen Intervallen eingespritzt um eine optimale Auftrennung zu erreichen. Es wurden Flussraten von $0,5 \mathrm{ml} / \mathrm{min}$ bis $2 \mathrm{ml} / \mathrm{min}$ verwendet. Die von der Säule kommenden Extraktkomponenten wurden bei einer Wellenlänge von $280 \mathrm{~nm}$ detektiert.

Die Trennung erfolgte in einem Gradienten mit einem Gemisch aus Methanol und Ameisensäure. Der Laufmittelgradient wurde variiert um eine optimale Trennung zu erreichen.

\section{Molekularbiologische Methoden}

\subsection{Isolierung von H. solani - DNA aus Sterilkulturen (nach OLIVIER et al.; 1998)}

H. solani wurde zunächst in V8 - Medium angezogen und 4 Wochen auf einem Schüttler bei $20^{\circ} \mathrm{C}$ im Dunkeln inkubiert. Das Myzel wurde anschließend geerntet, durch einen Faltenfilter filtriert und gefriergetrocknet. Das trockene Myzel wurde in der Kugelmühle zu einem feinen Puder vermahlen. $100 \mathrm{~g}$ des pulverisierten Myzels wurde in $1 \mathrm{ml} 150 \mathrm{mM}$ EDTA, $50 \mathrm{mM}$ Tris $\mathrm{HCl}(\mathrm{pH} 8,0)$ und $3 \%$ SDS bei $65^{\circ} \mathrm{C} 1 \mathrm{~h}$ lang inkubiert. Nach einer Phenol:Chloroform (1:1) Extraktion folgte eine Chloroformextraktion. Die DNA wurde mit $20 \%$ PEG 8000, versetzt mit 2,5 M NaCl, niedergeschlagen und bei $4^{\circ} \mathrm{C}$ über Nacht im Kühlraum inkubiert. Am folgenden Tag wurde die Probe zentrifugiert und mit 70 \% Ethanol gewaschen. Abschließend wurde der Niederschlag in einer Vakuumzentrifuge getrocknet und in $100 \mu$ reinstem Wasser aufgenommen.

\subsection{Isolierung von $H$. solani DNA aus Pflanzenproben}

Die Isolierung von Silberschorf-DNA aus Pflanzenproben erfolgte in den meisten Fällen mit unterirdischen Pflanzenteilen. Um Anhaftungen von $H$. solani Konidien oder 
Myzel zu entfernen, wurden die Pflanzenteile sorgfältig gewaschen und mit $70 \%$ Ethanol gereinigt. Danach wurden sie im Trockenschrank bei $80^{\circ} \mathrm{C}$ getrocknet und anschließend abgekühlt. Für den Zellaufschluss und die Extraktion der DNA wurde das Material in 1,5 ml Reaktionsgefäße überführt und in flüssigem Stickstoff tiefgefroren. Anschließend wurden die Proben in einer Kugelmühle 2 × 5 min gemahlen, wobei zwischendurch die Proben erneut in flüssigem Stickstoff getaucht wurden. Anschließend erfolgte die Aufreinigung der DNA mit Hilfe des Invisorb®Spin Plant Mini Kit. Zunächst wurde die pulverisierte Probe mit $400 \mu$ l Lysis-Puffer und $20 \mu 1$ Proteinase $\mathrm{K}$ aus dem Kit versetzt und für mindestens $30 \mathrm{~min}$ bei $65^{\circ} \mathrm{C}$ inkubiert. Anschließend wurde die Suspension auf eine im Kit enthaltene Säule zur Isolierung von DNA gegeben und 1 min bei 12000 rpm zentrifugiert. Zu dem Durchlauf wurden $200 \mu 1$ Bindungs-Puffer P gegeben und gevortext. Die Probe wurde auf eine neue Säule der selben Art wie oben beschrieben gegeben und für 1 min inkubiert, worauf ein weiterer Zentrifugationsschritt folgte (1 min, $12000 \mathrm{rpm}$ ). Der Durchlauf wurde verworfen und die an der Säule gebundene DNA einmal mit Waschpuffer I und zweimal mit Waschpuffer II gewaschen. Zwischendurch erfolgten jeweils Zentrifugationen (1 min, 12000 rpm). Nach nochmaliger Zentrifugation bei 12000 rpm für 2 min zum Entfernen der Waschpufferreste erfolgte die Eluation der DNA von der Säule mit $100 \mu$ auf $65^{\circ} \mathrm{C}$ vorgewärmtem Eluationspuffer D. Die Säule wurde $3 \mathrm{~min}$ in diesem Puffer inkubiert um die DNA möglichst vollständig von der Säule zu desorbieren. Mit Hilfe der finalen Zentrifugation (1 min, $10000 \mathrm{rpm}$.) wurde der die DNA enthaltene Eluationspuffer in einem E - Cup gesammelt.

\subsection{Isolierung von $H$. solani DNA aus stärkehaltigen Knollenproben}

Um zu untersuchen, ob der Pilz in der Lage ist, sich systemisch auszubreiten, wurden Knollenproben aus dem Leitbündelring mittels PCR auf Anwesenheit von H. solani geprüft. Da die Anwesenheit von Einlagerungsstärke unter Umständen die PCR stören kann, wurde die in Kapitel 18.2 beschriebene Isolierung von Pilz-DNA folgendermaßen modifiziert. Die Knollenproben wurden zunächst gefriergetrocknet. Anschließend wurden die Proben in der Kugelmühle zu Pulver vermahlen. Zunächst wurde die pulverisierte Probe ebenfalls mit $400 \mu$ Lysis-Puffer und $20 \mu$ l Proteinase K aus dem Invisorb ${ }^{\circ}$ Spin Plant Mini Kit versetzt und für mindestens $30 \mathrm{~min}$ bei $65^{\circ} \mathrm{C}$ inkubiert. 
Anschließend wurde die Probe mit $125 \mu$ l einer 5M NaCl Lösung versetzt und gemischt. Dann wurden $53 \mu$ einer $10 \%$ (w/v) CTAB Lösung hinzugegeben, vermischt und 10 min bei $65^{\circ} \mathrm{C}$ inkubiert. Die Ansätze wurden auf Eis gestellt und mit einem Volumen Chloroform-Isoamylalkohol (1:24) gemischt. Die Proben wurden $30 \mathrm{~min}$ auf Eis inkubiert und anschließend die Phasentrennung durch Zentrifugation herbeigeführt (15000xg, $\left.4{ }^{\circ} \mathrm{C}, 10 \mathrm{~min}\right)$. Der Überstand wurde in ein neues Eppendorf Reaktionsgefäß überführt und mit $200 \mu \mathrm{l}$ des Bindungspuffers des Invisorb®Spin Plant Mini Kit vermengt. Die weitere Aufreinigung erfolgte wie unter 18.2 beschrieben.

\subsection{PCR}

Für die Amplifikation pilzlicher Sequenzen wurden $10 \mu 1$ Reaktionsansätze verwendet. Die Konzentration der Primer in den Ansätzen betrug $1 \mu \mathrm{M}$. Als Matritze wurde $10 \mathrm{ng}$ extrahierte Gesamt - DNA eingesetzt. Die Reaktion erfolgte im 1 fach konzentrierten Reaktionspuffer, der vom Hersteller der thermostabilen Polymerase geliefert wurde. Eingesetzt wurden in der Reaktion 0,5U Taq-Polymerase. Die eingesetzte Nukleotidkonzentration betrug 0,2 $\mathrm{mM}$ und die $\mathrm{MgCl}_{2}$-Konzentration 1,5 mM.

Es wurde ein Gerät mit Deckelheizung gewählt um Kondensationen am Deckel der Reaktionsgefäße und somit Verfälschung der PCR zu verhindern. Routinemäßig wurden 2 Minuten bei $94^{\circ} \mathrm{C}$ denaturiert und anschließend 29-32 Zyklen des folgenden Temperaturprofils durchlaufen: 1 min Denaturierung bei $94^{\circ} \mathrm{C}, 30 \mathrm{~s}-2 \mathrm{~min}$ Hybridisierung bei der spezifischen Anlagerungstemperatur des Oligonukleotids, 1-3 min Synthese bei $72^{\circ} \mathrm{C}$. Die Reaktion wurde durch einen Syntheseschritt von $10 \mathrm{~min}$ bei $72^{\circ} \mathrm{C}$ abgeschlossen. Durch Abkühlen auf $4^{\circ} \mathrm{C}-8^{\circ} \mathrm{C}$ wurde die Reaktion beendet.

Die primerspezifische Temperatur errechnet sich aus der Nukleotidsequenz der verwendeten Primer nach folgender Formel:

$$
\mathrm{Tm}=\left((\mathrm{G} / \mathrm{C}) \times 4^{\circ} \mathrm{C}+(\mathrm{A} / \mathrm{T}) \times 2^{\circ} \mathrm{C}-5^{\circ} \mathrm{C}\right)
$$

Dabei sollte aber auf eine empirische Optimierung der primerspezifischen Temperatur nie verzichtet werden. Die Synthesezeit bei $72^{\circ} \mathrm{C}$ wurde der Länge des zu amplifizierenden DNA-Fragmentes angepasst. Hierbei wurde von einer Prozessierungsrate von 1000 Basen/ Minute ausgegangen. Bei sehr geringer MatrizenDNA Menge wurde eine nestedPCR durchgeführt. Zunächst wurde eine Amplifikation der ITS Region mit den Primern ITS4 und ITS5 nach WHITE et al. (1990) 
vorgenommen. Das Produkt dieser PCR wurde wiederum als Matrize für PCR mit $H$. solani spezifischen Primern verwendet.

\subsection{Gelelektrophorese}

Zu der aufzutrennenden DNA wurden 0,3 Volumen Ladepuffer (Kapitel 3) gegeben. In einem horizontalen Agarosegel mit einer Agarosekonzentration von $1 \%$ in TBE Puffer wurde die DNA 90 min bei 110 Volt elektrophoretisch getrennt. Das Gel wurde anschließend 10 min in 0,1 \% Ethidiumbromid Bad gefärbt und 10 min in $\mathrm{H}_{2} \mathrm{O}$ entfärbt. DNA - Banden wurden mit Hilfe eines UV - Transiluminators $(\lambda=254 \mathrm{~nm})$ detektiert. Als Größenstandard diente eine GENE RULER 1kb DNA-Leiter. Die Größe der DNAFragmente wurde durch Vergleich mit dem Größenstandard ermittelt.

\section{Statistische Auswertung}

Die statistische Verrechnung der Daten erfolgte mit dem Programm STATGRAPHICS ${ }^{\circledR}$ Plus Version 5.1, wobei der Vergleich der Mittelwerte der Varianten hinsichtlich signifikanter Unterschiede mit dem t-Test durchgeführt wurde. Die Signifikanz der Regression wurden mit dem Durbin-Watson-Test berechnet. Die Irrtumswahrscheinlichkeit wird wie folgt angegeben: n.s.: nicht signifikant; $*=p<0,10$; $* *=\mathrm{p}<0,05 ; * * *=\mathrm{p}<0,01$. 


\section{Ergebnisse}

\section{Isolierung und Anzucht von $\boldsymbol{H}$. solani zur Herstellung des Inokulums}

\subsection{Isolierung von H. solani von Knollen und Erstellung einer Isolate Bank}

Da $H$. solani eine Vielzahl von unterschiedlichen Isolaten hervorbringt, die sich im Verhalten und Aggressivität unterscheiden, wurde im Verlauf der drei Versuchsjahre eine Isolate - Bank von Knollen isolierten Pilzen angelegt. Insgesamt konnten 24 Isolate in der beschriebenen Weise isoliert und als Einzelkonidien Isolate gereinigt werden. Das Wachstum auf Hafermehlagar war ausreichend, so dass eine Lagerung auf Dauer bei $4^{\circ} \mathrm{C}$ möglich war. Die Isolate unterschieden sich stark in Wachstumsgeschwindigkeit, Farbe und Bildung von Konidien. Einige wiesen weißes, andere schwarzes Myzel auf. Während einige Isolate schon nach 2 Wochen mit der Bildung von Konidien begannen, zeigten andere erst nach 6 Wochen erste Konidien. Auf Grund dieser Inhomogenität ist es daher nötig, bei der Bestimmung von $H$. solani auf Agarmedium immer eine Überprüfung bei mindestens 10facher Vergrößerung unter dem Binokular bzw. Mikroskop durchzuführen. Außerdem ist das Vorhandensein von Konidien (Abbildung 1 in der Einleitung) zur eindeutigen Bestimmung des Pilzes unerlässlich.

\subsection{Isolierung von $\boldsymbol{H}$. solani aus Bodenproben mittels Flotationsverfahren}

In diesem Versuch wurde getestet, ob Silberschorf Konidien lipophile Eigenschaften besitzen und diese bei der Isolierung des Pilzes aus Bodenproben einsetzbar sind. Es wurden Öle verschiedener Dichten und Viskositäten getestet. In keiner der untersuchten Ölemulsionen konnten jedoch $H$. solani Konidien gefunden werden. Auch bei Variation des Versuchsablaufs wurden keine Konidien in der Ölphase nachgewiesen. In den Kontrollen der Wasserphase konnten dagegen immer eine große Anzahl Konidien gezählt werden. Dies zeigt, dass $H$. solani Konidien nicht lipophil, sondern viel eher lipophob sind. Diese Eigenschaft kann daher nicht zur Isolation von Silberschorf aus Boden genutzt werden. 


\subsection{Einsatz von Bengal Rosa zur Selektion von $\boldsymbol{H}$. solani aus Bodenproben}

Auf Grund des langsamen Wachstums von H. solani auf Nährböden wurde der Einsatz von Bengal Rosa als Radikalbildner als Selektionsvorteil gegenüber anderen bodenbürtigen Mikroorganismen bei Isolierung aus Bodenproben getestet. Zunächst musste der Einfluss des Zusatzes auf das Wachstum von $H$. solani selbst getestet werden (Graphik 1). Es wurde die Koloniegröße sowie die Konidienzahl nach 4 Wochen ermittelt und mit Agarplatten ohne Bengal Rosa Zusatz verglichen.

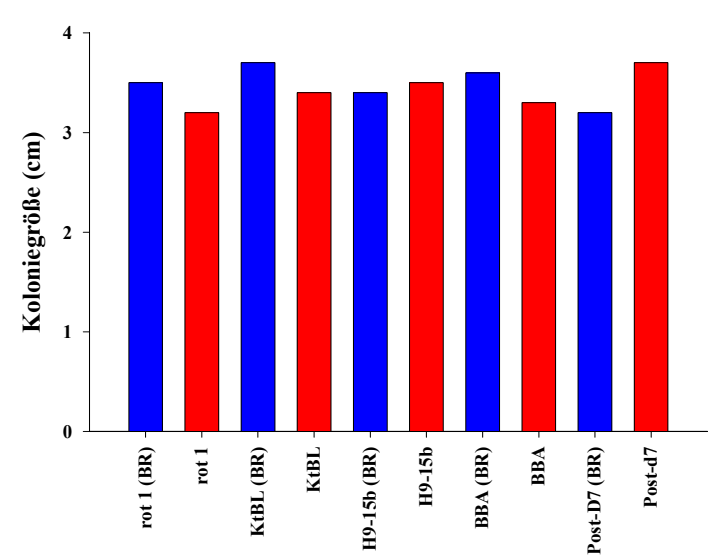

H. solani Isolate und Versuchsvarianten

A
n.S.

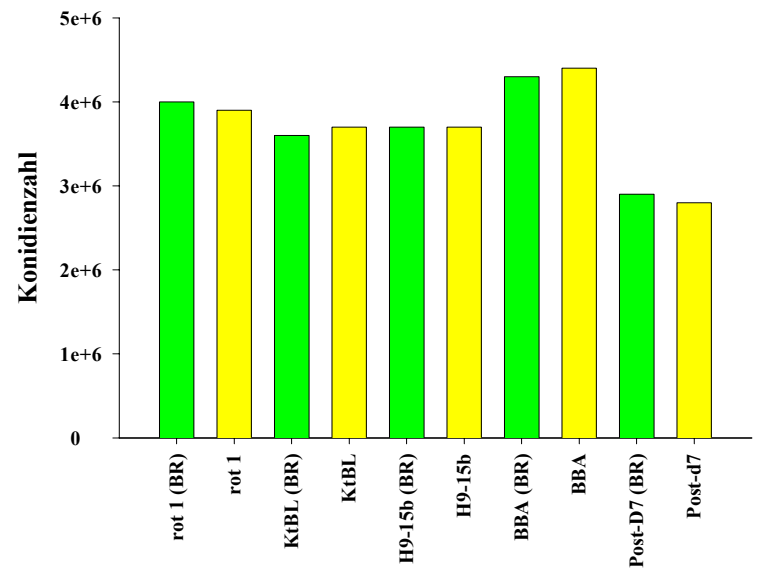

$H$. solani Isolate und Versuchsvarianten

B

n.S.

Graphik 1: Entwicklung von $\boldsymbol{H}$. solani auf V8-Agar mit Bengal Rosa. A: Die x-Achse gibt die H. solani Isolate und die Versuchsvarianten, die y-Achse die Größe der Kolonien in $\mathrm{cm}$ an. $\mathrm{BR}=$ Bengal Rosa. Die blauen Säulen geben die Medien mit Bengal Rosa, die roten ohne wieder. Es konnte kein signifikanter Unterschied gefunden werden (n.s.: nicht signifikant). B: Die $\mathrm{x}$-Achse gibt die $H$. solani Isolate und die Versuchsvarianten, die y-Achse die Konidienanzahl an. BR= Bengal Rosa. Die grünen Säulen geben die Medien mit Bengal Rosa, die roten ohne wieder. Es konnte kein signifikanter Unterschied gefunden werden (n.s.: nicht signifikant). Die Versuche wurden fünffach wiederholt.

Die Koloniegrößen zeigten keinen signifikanten Unterschied zwischen den beiden Varianten, auch die Anzahl an gebildeten Konidien war annähernd gleich. Ein negativer Einfluss des Bengal Rosas auf die Entwicklung von $H$. solani konnte demnach nicht festgestellt werden. Zur Isolierung des Pilzes aus Bodenproben wurden eine Verdünnungsreihe von mit Konidien versetzten Bodenproben ausplattiert und bei verschiedenen Temperaturen inkubiert (Tabelle 7). 
Tabelle 7: Wachstumstest von $\boldsymbol{H}$. solani auf V8 - Agar mit Bengal Rosa. Erdproben wurden mit $H$. solani Konidien vermischt und Verdünnungsreihen bis $10^{-4}$ ausplattiert. Die Platten wurden im Dunkeln bei 8,12, 16 und $20^{\circ} \mathrm{C}$ inkubiert und nach 2, 4, 6, 8 und 10 Tagen auf Silberschorfkolonien überprüft.

\begin{tabular}{|c|c|c|c|c|c|}
\hline \multirow[b]{2}{*}{ Tage } & \multirow[b]{2}{*}{ Verdünnung } & \multicolumn{4}{|c|}{ Temperatur: } \\
\hline & & $8^{\circ} \mathrm{C}$ & $12^{\circ} \mathrm{C}$ & $16^{\circ} \mathrm{C}$ & $20^{\circ} \mathrm{C}$ \\
\hline \multirow{5}{*}{2} & unverdünnt & Kein Pilzwachstum & $\begin{array}{c}\text { Einzelkolonien } \\
\text { verschiedener Pilze }\end{array}$ & $\begin{array}{c}\text { Überwachsen durch } \\
\text { andere Pilze }\end{array}$ & 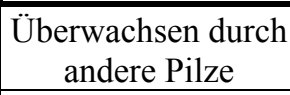 \\
\hline & $10^{-1}$ & Kein Pilzwachstum & $\begin{array}{c}\text { Einzelkolonien } \\
\text { verschiedener Pilze }\end{array}$ & $\begin{array}{c}\text { Einzelkolonien } \\
\text { verschiedener Pilze }\end{array}$ & $\begin{array}{c}\text { Überwachsen durch } \\
\text { andere Pilze }\end{array}$ \\
\hline & $10^{-2}$ & Kein Pilzwachstum & $\begin{array}{c}\text { Einzelkolonien } \\
\text { verschiedener Pilze }\end{array}$ & $\begin{array}{c}\text { Einzelkolonien } \\
\text { verschiedener Pilze }\end{array}$ & $\begin{array}{c}\text { Überwachsen durch } \\
\text { andere Pilze }\end{array}$ \\
\hline & $10^{-3}$ & Kein Pilzwachstum & Kein Pilzwachstum & $\begin{array}{c}\text { Einzelkolonien } \\
\text { verschiedener Pilze }\end{array}$ & $\begin{array}{c}\text { Überwachsen durch } \\
\text { andere Pilze }\end{array}$ \\
\hline & $10^{-4}$ & Kein Pilzwachstum & Kein Pilzwachstum & $\begin{array}{c}\text { Einzelkolonien } \\
\text { verschiedener Pilze }\end{array}$ & $\begin{array}{c}\text { Überwachsen durch } \\
\text { andere Pilze }\end{array}$ \\
\hline \multirow{5}{*}{4} & unverdünnt & Kein Pilzwachstum & $\begin{array}{l}\text { Überwachsen durch } \\
\text { andere Pilze }\end{array}$ & $\begin{array}{c}\text { Einzelkolonien } \\
\text { verschiedener Pilze }\end{array}$ & $\begin{array}{c}\text { Überwachsen durch } \\
\text { andere Pilze }\end{array}$ \\
\hline & $10^{-1}$ & Kein Pilzwachstum & $\begin{array}{c}\text { Einzelkolonien } \\
\text { verschiedener Pilze }\end{array}$ & $\begin{array}{c}\text { Einzelkolonien } \\
\text { verschiedener Pilze }\end{array}$ & $\begin{array}{c}\text { Überwachsen durch } \\
\text { andere Pilze }\end{array}$ \\
\hline & $10^{-2}$ & Kein Pilzwachstum & $\begin{array}{c}\text { Einzelkolonien } \\
\text { verschiedener Pilze }\end{array}$ & $\begin{array}{c}\text { Einzelkolonien } \\
\text { verschiedener Pilze }\end{array}$ & $\begin{array}{c}\text { Überwachsen durch } \\
\text { andere Pilze }\end{array}$ \\
\hline & $10^{-3}$ & Kein Pilzwachstum & $\begin{array}{c}\text { Einzelkolonien } \\
\text { verschiedener Pilze }\end{array}$ & $\begin{array}{c}\text { Einzelkolonien } \\
\text { verschiedener Pilze } \\
\end{array}$ & $\begin{array}{c}\text { Überwachsen durch } \\
\text { andere Pilze }\end{array}$ \\
\hline & $10^{-4}$ & Kein Pilzwachstum & Kein Pilzwachstum & $\begin{array}{c}\text { Einzelkolonien } \\
\text { verschiedener Pilze }\end{array}$ & $\begin{array}{c}\text { Überwachsen durch } \\
\text { andere Pilze }\end{array}$ \\
\hline \multirow{5}{*}{6} & unverdünnt & Kein Pilzwachstum & $\begin{array}{l}\text { Überwachsen durch } \\
\text { andere Pilze }\end{array}$ & $\begin{array}{c}\text { Überwachsen durch } \\
\text { andere Pilze }\end{array}$ & $\begin{array}{c}\text { Überwachsen durch } \\
\text { andere Pilze }\end{array}$ \\
\hline & $10^{-1}$ & Kein Pilzwachstum & $\begin{array}{l}\text { Überwachsen durch } \\
\text { andere Pilze }\end{array}$ & $\begin{array}{c}\text { Überwachsen durch } \\
\text { andere Pilze }\end{array}$ & $\begin{array}{c}\text { Überwachsen durch } \\
\text { andere Pilze }\end{array}$ \\
\hline & $10^{-2}$ & Kein Pilzwachstum & $\begin{array}{c}\text { Einzelkolonien } \\
\text { verschiedener Pilze }\end{array}$ & $\begin{array}{c}\text { Einzelkolonien } \\
\text { verschiedener Pilze }\end{array}$ & $\begin{array}{l}\text { Überwachsen durch } \\
\text { andere Pilze }\end{array}$ \\
\hline & $10^{-3}$ & Kein Pilzwachstum & $\begin{array}{c}\text { Einzelkolonien } \\
\text { verschiedener Pilze }\end{array}$ & $\begin{array}{c}\text { Einzelkolonien } \\
\text { verschiedener Pilze }\end{array}$ & $\begin{array}{c}\text { Überwachsen durch } \\
\text { andere Pilze }\end{array}$ \\
\hline & $10^{-4}$ & Kein Pilzwachstum & $\begin{array}{c}\text { Einzelkolonien } \\
\text { verschiedener Pilze }\end{array}$ & $\begin{array}{c}\text { Einzelkolonien } \\
\text { verschiedener Pilze }\end{array}$ & $\begin{array}{c}\text { Überwachsen durch } \\
\text { andere Pilze }\end{array}$ \\
\hline \multirow{5}{*}{8} & unverdünnt & Kein Pilzwachstum & $\begin{array}{c}\text { Überwachsen durch } \\
\text { andere Pilze }\end{array}$ & $\begin{array}{c}\text { Überwachsen durch } \\
\text { andere Pilze }\end{array}$ & $\begin{array}{c}\text { Überwachsen durch } \\
\text { andere Pilze }\end{array}$ \\
\hline & $10^{-1}$ & Kein Pilzwachstum & $\begin{array}{c}\text { Überwachsen durch } \\
\text { andere Pilze }\end{array}$ & $\begin{array}{c}\text { Überwachsen durch } \\
\text { andere Pilze }\end{array}$ & $\begin{array}{c}\text { Überwachsen durch } \\
\text { andere Pilze }\end{array}$ \\
\hline & $10^{-2}$ & Kein Pilzwachstum & $\begin{array}{c}\text { Überwachsen durch } \\
\text { andere Pilze }\end{array}$ & $\begin{array}{c}\text { Zwei H. solani } \\
\text { Kolonien } \\
\end{array}$ & $\begin{array}{l}\text { Überwachsen durch } \\
\text { andere Pilze }\end{array}$ \\
\hline & $10^{-3}$ & Kein Pilzwachstum & $\begin{array}{c}\text { Einzelkolonien } \\
\text { verschiedener Pilze }\end{array}$ & $\begin{array}{c}\text { Eine } H . \text { solani } \\
\text { Kolonie }\end{array}$ & $\begin{array}{c}\text { Überwachsen durch } \\
\text { andere Pilze }\end{array}$ \\
\hline & $10^{-4}$ & Kein Pilzwachstum & $\begin{array}{c}\text { Einzelkolonien } \\
\text { verschiedener Pilze }\end{array}$ & $\begin{array}{c}\text { Einzelkolonien } \\
\text { verschiedener Pilze } \\
\end{array}$ & $\begin{array}{c}\text { Überwachsen durch } \\
\text { andere Pilze }\end{array}$ \\
\hline \multirow{5}{*}{10} & unverdünnt & $\begin{array}{c}\text { Einzelkolonien } \\
\text { verschiedener Pilze }\end{array}$ & $\begin{array}{c}\text { Überwachsen durch } \\
\text { andere Pilze }\end{array}$ & $\begin{array}{l}\text { Überwachsen durch } \\
\text { andere Pilze }\end{array}$ & $\begin{array}{c}\text { Überwachsen durch } \\
\text { andere Pilze }\end{array}$ \\
\hline & $10^{-1}$ & Kein Pilzwachstum & $\begin{array}{c}\text { Überwachsen durch } \\
\text { andere Pilze }\end{array}$ & $\begin{array}{l}\text { Überwachsen durch } \\
\text { andere Pilze }\end{array}$ & $\begin{array}{l}\text { Überwachsen durch } \\
\text { andere Pilze }\end{array}$ \\
\hline & $10^{-2}$ & Kein Pilzwachstum & $\begin{array}{c}\text { Überwachsen durch } \\
\text { andere Pilze }\end{array}$ & $\begin{array}{c}\text { Überwachsen durch } \\
\text { andere Pilze }\end{array}$ & $\begin{array}{l}\text { Überwachsen durch } \\
\text { andere Pilze }\end{array}$ \\
\hline & $10^{-3}$ & Kein Pilzwachstum & $\begin{array}{c}\text { Einzelkolonien } \\
\text { verschiedener Pilze }\end{array}$ & $\begin{array}{c}\text { Überwachsen durch } \\
\text { andere Pilze }\end{array}$ & $\begin{array}{c}\text { Überwachsen durch } \\
\text { andere Pilze }\end{array}$ \\
\hline & $10^{-4}$ & Kein Pilzwachstum & $\begin{array}{c}\text { Einzelkolonien } \\
\text { verschiedener Pilze }\end{array}$ & $\begin{array}{c}\text { Überwachsen durch } \\
\text { andere Pilze }\end{array}$ & $\begin{array}{c}\text { Überwachsen durch } \\
\text { andere Pilze }\end{array}$ \\
\hline
\end{tabular}


Bei einer Temperatur von $8^{\circ} \mathrm{C}$ zeigte sich zu keinem Zeitpunkt Wachstum von $H$. solani. Auch das Wachstum anderer bodenbürtiger Pilze war stark eingeschränkt. Bei $12^{\circ} \mathrm{C}$ konnten nach 2 Tagen Kolonien bei einer Verdünnung von $10^{0}-10^{-2}$ Kolonien gefunden werden, die jedoch auf Grund des Fehlens von Konidien nicht eindeutig als $H$. solani identifiziert werden konnten. Nach 6 Tagen waren noch immer keine Konidien gebildet, jedoch die Platten von anderen Pilzen überwachsen. Bei den Verdünnungsstufen $10^{-3}$ und $10^{-4}$ konnten keine $H$. solani ähnlichen Kolonien gefunden werden. Bei $16^{\circ} \mathrm{C}$ zeigten sich nach 2 Tagen zahlreiche Silberschorf ähnliche Kolonien auf allen Platten der Verdünnungsstufen $10^{-1}-10^{-3}$ während die Platten mit unverdünnter Suspension bereit von anderen Pilzen überwachsen waren. Nach 4 Tagen waren die Platten der Verdünnungsstufe $10^{-1}$ ebenfalls überwachsen. Nach 8 Tagen konnten bei einem Versuchsdurchlauf jedoch 1 - 2 Silberschorfkolonien auf Grund der Bildung von Konidien eindeutig auf Platten der Verdünnungsstufen $10^{-2}$ und $10^{-3}$ identifiziert und isoliert werden. Bei der Inkubation der Testplatten bei $20^{\circ} \mathrm{C}$ waren sämtliche Platten bereits nach 2 Tagen vollständig von der bodenbürtigen Mikroflora überwuchert, so dass die Isolierung von $H$. solani auch bei möglichem Wachstum nicht mehr möglich war. Insgesamt war die Ausbeute an isolierten Silberschorfkolonien bei der eingesetzten Konidienmenge äußerst gering. Bei der Überprüfung der ausplattierten ungekeimten Silberschorfkonidien unter dem Mikroskop konnte festgestellt werden, dass zwar viele Konidien mit ausplattiert worden waren, jedoch nicht zur Keimung gelangten. Insgesamt wurde eine Keimrate von $10 \%$ nie überschritten. Es wurde auf einen Einfluss des Bodens geschlossen und das Ergebnis im später folgenden Bodensuppressivitätstest untersucht. Die Isolierung von Silberschorf aus Bodenproben erwies sich daher auf Grund des langsamen Wachstums des Pilzes als nach wie vor schwierig.

\subsection{Wachstumsansprüche von $H$. solani in Flüssig - bzw. auf Agarmedium}

Da die Kultivierung von $H$. solani auf PDA bisher sehr langwierig und die Ausbeute an Konidien sehr gering war, wurden Wachstumstests des Pilzes in verschiedenen Flüssigmedien bzw. auf verschiedenen Agar-Medien durchgeführt. Das Wachstum des Pilzes in den Flüssigmedien zeigte sich sehr unterschiedlich (Tab. 8, Abb. 6). 
Tabelle 8: Wachstumstest von Silberschorf in Flüssigmedium. Das Isolat H9 - 5a wurde auf vier verschiedene Medien getestet. Das Aussehen, die Trockenmasse in $200 \mathrm{ml}$ angesetztem Medium und die Konidien pro $\mathrm{ml}$ wurden nach 3 Wochen Inkubation bei $20^{\circ} \mathrm{C}$ im Dunkeln auf dem Rotationsschüttler bestimmt.

\begin{tabular}{|c|c|c|c|}
\hline Medium & $\begin{array}{c}\text { Aussehen der } \\
\text { Kolonien }\end{array}$ & $\begin{array}{c}\text { Trockenmasse in } \\
\text { Gramm pro 200 ml }\end{array}$ & $\begin{array}{c}\text { Konidienanzahl } \\
\text { pro ml }\end{array}$ \\
\hline Kartoffel-Dextrose & $\begin{array}{c}\text { Schwarz, kugelförmig, } \\
0,5-1 \mathrm{~cm} \varnothing\end{array}$ & 1,82 & 0 \\
\hline Czapek-Dox & $\begin{array}{c}\text { Weiß, kugelförmig, } \\
5-6 \mathrm{~cm} \varnothing\end{array}$ & 2,03 & 0 \\
\hline YEPD & $\begin{array}{c}\text { Weiß/schwarz, } \\
\text { kugelförmig, } \\
0,2-2 \text { cm } \varnothing\end{array}$ & 3,22 & 0 \\
\hline Malzextrakt & $\begin{array}{c}\text { Schwarz, kugelförmig, } \\
1-3 \text { cm Ø }\end{array}$ & 0,93 & 0 \\
\hline
\end{tabular}

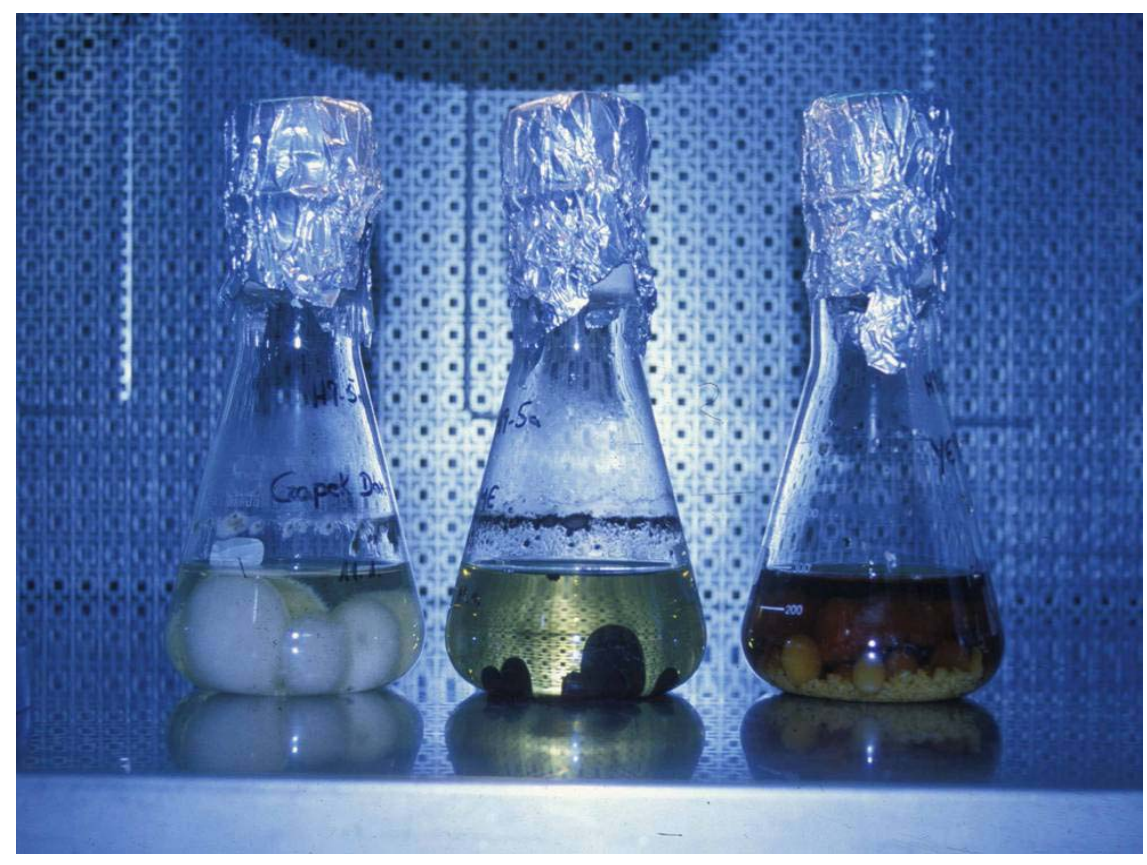

Abbildung 6: Silberschorf Kolonien in verschiedenen Medien (Schüttlerkulturen). Von links nach rechts: Czapek Dox-, YEPD-, Malzextraktmedium; Das H. solani Isolat H9-5a wurde 3 Wochen bei $20^{\circ} \mathrm{C}$ im Dunkeln auf dem Rotationsschüttler inkubiert. Es ist deutlich zu erkennen, dass der Pilz in unterschiedlichen Formen wächst.

In PD-Medium wuchs der Pilz in kleinen, schwarz gefärbten Kugeln von ca. $0,5-1 \mathrm{~cm}$ Durchmesser. Im Medium konnten zu keinem Zeitpunkt Konidien nachgewiesen werden. Das Trockengewicht des nach 3 Wochen geernteten Myzels betrug 1,82 g/200 ml. Im Czapex-Dox Medium wuchsen die H. solani Kolonien als große weiße Kugeln mit einem Durchmesser von ca. 5-6 cm. Auch hier konnten keine Konidien im Medium festgestellt werden. Das Trockengewicht des Myzels betrug 2,03 g in $200 \mathrm{ml}$. In YEPD-Medium wuchs das Myzel in sehr kleinen bis mittelgroßen, weißen und schwarzen Kugeln mit einem Durchmesser von 0,2-2 cm Größe. Das Trockengewicht 
in $200 \mathrm{ml}$ Medium erreichte 3,22 $\mathrm{g} / 200 \mathrm{ml}$. Auch hier konnten bei mehreren Probeziehungen keinerlei Konidien nachgewiesen werden. In Malzextrakt-Medium bildete der Pilz mittelgroße, schwarze, kugelförmige Kolonien mit 1-3 cm Durchmesser. Das Trockengewicht lag bei 0,93 g/200 ml. Auch bei diesem Medium konnten keine Konidien gefunden werden. Eine Inokulation von Kartoffeln mit in Flüssigmedium gezogenem Pilz erwies sich somit als nicht möglich, da zum einen der Pilz nicht homogen im gesamten Medium verteilt war, sondern kugelförmige Kolonien bildete. Zum anderen wurden in keinem Medium Konidien gebildet, welche eine Übertragung des Pilzes auf die Knollen erst möglich macht.

Der Wachstumstest wurde ebenfalls auf Agarmedium im Dunkeln und unter NUVBestrahlung durchgeführt. Hierzu wurde PDA, YEPD-Agar und Gemüsesaft (V8) Agar verwendet. Zunächst wurde das Aussehen der Kolonien bestimmt. Auf PDA wuchsen die Kolonien auf der Agaroberfläche mit grauem Myzel und undeutlichem Kolonienrand. Auf YEPD Agar dagegen wuchs der Pilz in den Agar ein, das Myzel war grau und zeigte einen scharfen Wachstumsrand. Auf V8 - Agar wuchs der Pilz wie auf PDA auf der Agaroberfläche, das Myzel war grau gefärbt und an den Rändern stark ausgefranst. Es konnten bei keinem Nährboden Unterschiede zwischen den im Dunkeln inkubierten und den NUV-Licht bestrahlten Platten festgestellt werden. Die Wachstumsgeschwindigkeit des Pilzes unterschied sich stark voneinander. Nach 6 Wochen wurde der Durchmesser der Kolonien vermessen (Graphik 2).

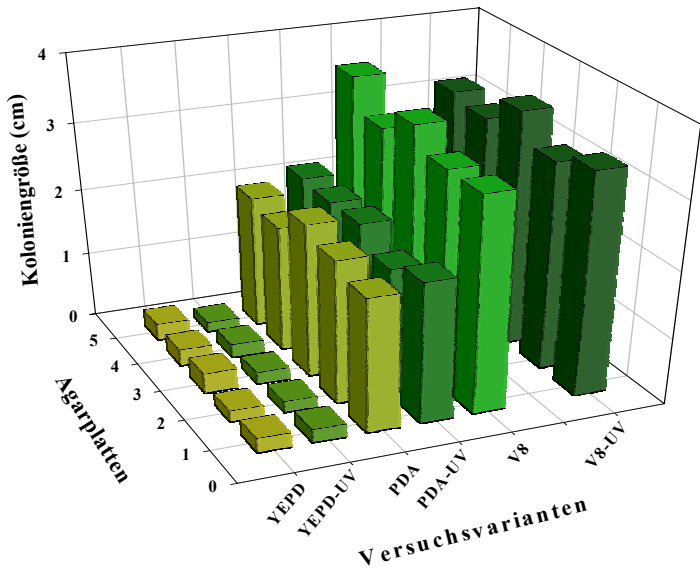

n.S.

Graphik 2: Wachstum von $H$. solani (Isolat H9-5a) auf verschiedenen Nährmedien und Beleuchtung. Auf der $x$-Achse sind die Versuchsvarianten, auf der y-Achse die Koloniengröße in $\mathrm{cm}$ und der z-Achse die untersuchten Agarplatten angegeben. UV=NUV-Bestrahlung; Der $\varnothing$ der Kolonien wurde nach 6 Wochen Inkubation bei $20^{\circ} \mathrm{C}$ im Dunkel bzw. unter NUV-Licht vermessen. Es bestehen keine signifikanten Unterschiede zwischen den Lichtvarianten (n.s.: nicht signifikant nach $\mathrm{t}-$ Test, $\mathrm{p} \leq 0,05$ ). Die Wachstumsgeschwindigkeit des Pilzes unterscheidet sich stark. 
Im Gegensatz zu dem bisher üblichen PDA wuchs der Pilz auf V8-Agar sehr gut, während auf YEPD-Agar kaum Myzel gebildet wurde. Während die H. solani Kolonien auf PDA und V8 - Agar stetig weiterwuchsen, stagnierte bei YEPD-Agar schon nach wenigen Tagen das Wachstum. Das schnellste Wachstum wurde auf V8-Medium nachgewiesen. Auch hier wurde kein Unterschied zwischen den Lichtvarianten gefunden. Da Inokulationen in erster Linie auf der Übertragung von Konidien beruht, wurden diese nach 5, 6, 7 und 8 Wochen von den Platten geschwemmt und ausgezählt (Graphik 3). Auf YEPD Agar wurden zu keinem Zeitpunkt und unter keinen Lichtbedingungen Konidien gebildet. Auch nach 8 Wochen konnten in der Zählkammer keine Konidien gefunden werden. Auf PDA wurde eine geringe Produktion von Konidien festgestellt, deren Menge im Versuchsverlauf schwankte. Es konnte kein Anstieg im Verlauf der 8 Wochen festgestellt werden. Auch zwischen den Lichtvarianten schwankte die Anzahl der gebildeten Konidien. Es konnte jedoch kein signifikanter Unterschied zwischen NUV-Beleuchtung und Dunkelinkubation festgestellt werden. Auf V8-Agar wurden schon nach 5 Wochen sehr viele Konidien gebildet. Im Versuchsverlauf schwankte die Zahl der gebildeten Konidien zwar, es konnte aber kein deutlicher Anstieg festgestellt werden. Auch zwischen den Lichtvarianten zeigten sich Unterschiede in der Anzahl der gebildeten Konidien, aber auch hier lies sich kein signifikanter Unterschied zwischen NUV -Bestrahlung und Dunkelheit feststellen.

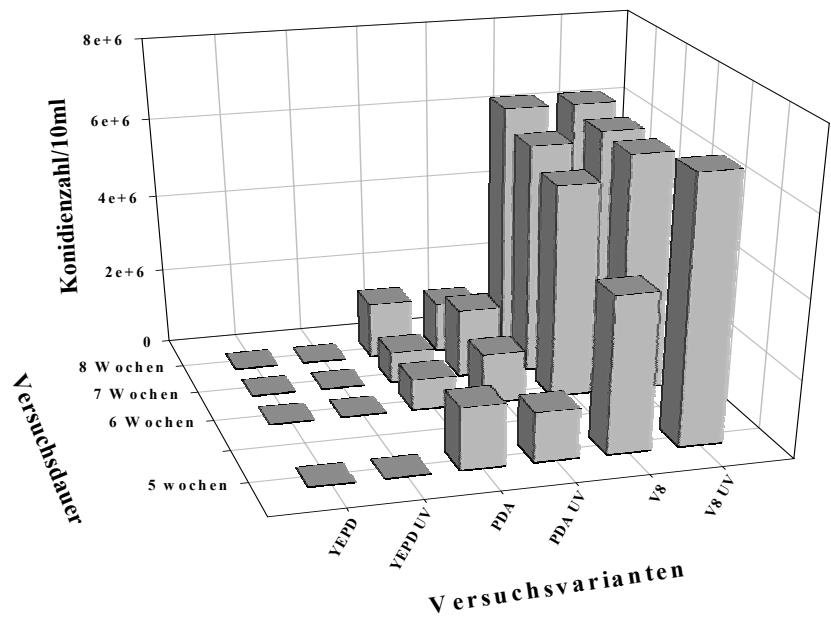

n.S.

Graphik 3: Konidienzahl von $H$. solani (Isolat H9 - 5a) auf verschiedenen Agarmedien und Beleuchtung. Auf der x-Achse sind die Nährmedien und die Beleuchtung, auf der y-Achse die Konidienzahl und auf der z-Achse die Versuchsdauer angegeben. UV = NUV-Bestrahlung; Es bestehen keine signifikanten Unterschiede zwischen den Lichtvarianten (n.s.: nicht signifikant nach $\mathrm{t}-\mathrm{Test}, \mathrm{p} \leq 0,05$ ). Auf V8-Medium werden die meisten Konidien gebildet. 


\section{Feldversuche}

Im ersten Versuchsjahr hatten alle Sorten einen geringen Vorbefall mit $H$. solani (Graphik 4).

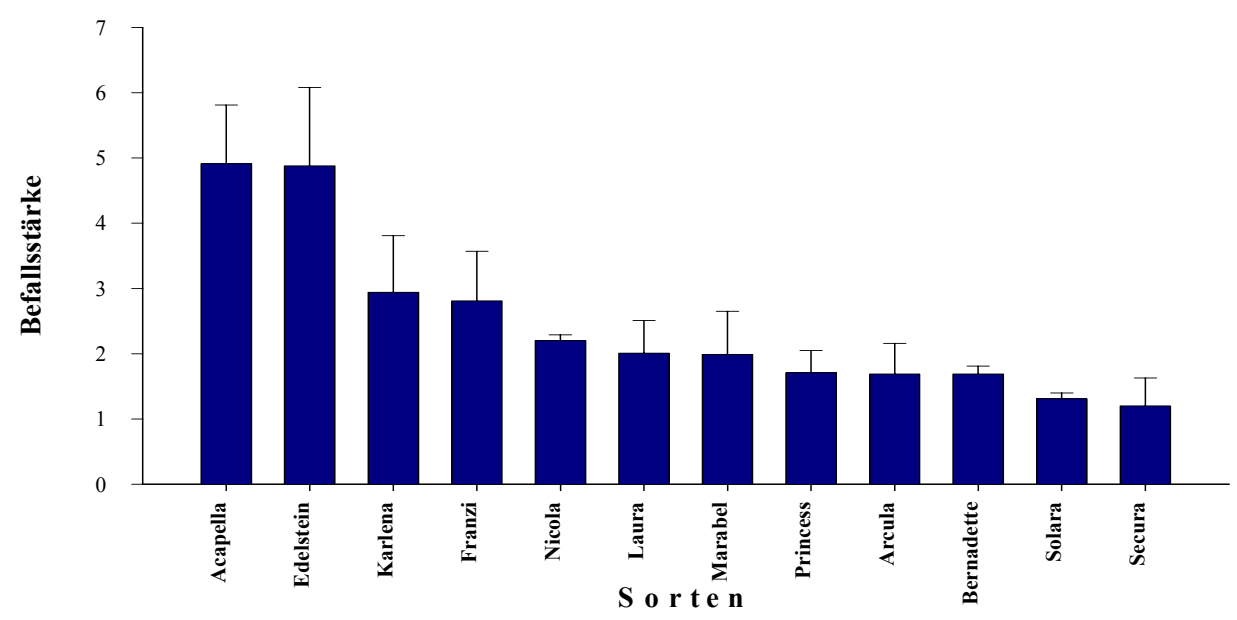

Graphik 4: Vorbefall des Pflanzgutes mit $\boldsymbol{H}$. solani im Versuchsjahr 2002. Auf der x-Achse sind die Sorten, auf der y-Achse die Befallsstärke von 0-7 angegeben (vgl. Kapitel 6 aus Material und Methoden). Die Intervalle geben die Standardabweichungen der jeweils 50 bonitierten Knollen wieder. Alle Sorten zeigten einen Vorbefall.

Das Pflanzgut wurde von sechs deutschen Züchtungsunternehmen zur Verfügung gestellt und stammt somit je nach Sorte aus unterschiedlichen Lagerbedingungen. Die jeweiligen Herkünfte und Lagerstandorte waren unbekannt.

Da sich Silberschorf hauptsächlich im Lager ausbreitet, kann somit aus diesen Daten kein Rückschluss auf das Anfälligkeitsverhalten der verschiedenen Sorten gezogen werden. Die inokulierten und gebeizten Knollen wurden an die Standorte Windeby, Groß Lüsewitz und Kaltenberg geliefert und bei günstiger Witterung gepflanzt. Im ersten Jahr traten an allen drei Versuchsstandorten bei den gleichen Sorten Auflaufprobleme auf (Graphik 5). Um zu klären, ob diese Auflaufprobleme möglicherweise durch die künstliche Inokulation induziert wurden, erfolgte das Auspflanzen von unbehandelten Rückstellproben des Pflanzgutes im Gewächshaus (ebenfalls Graphik 5, Abb. 7). 


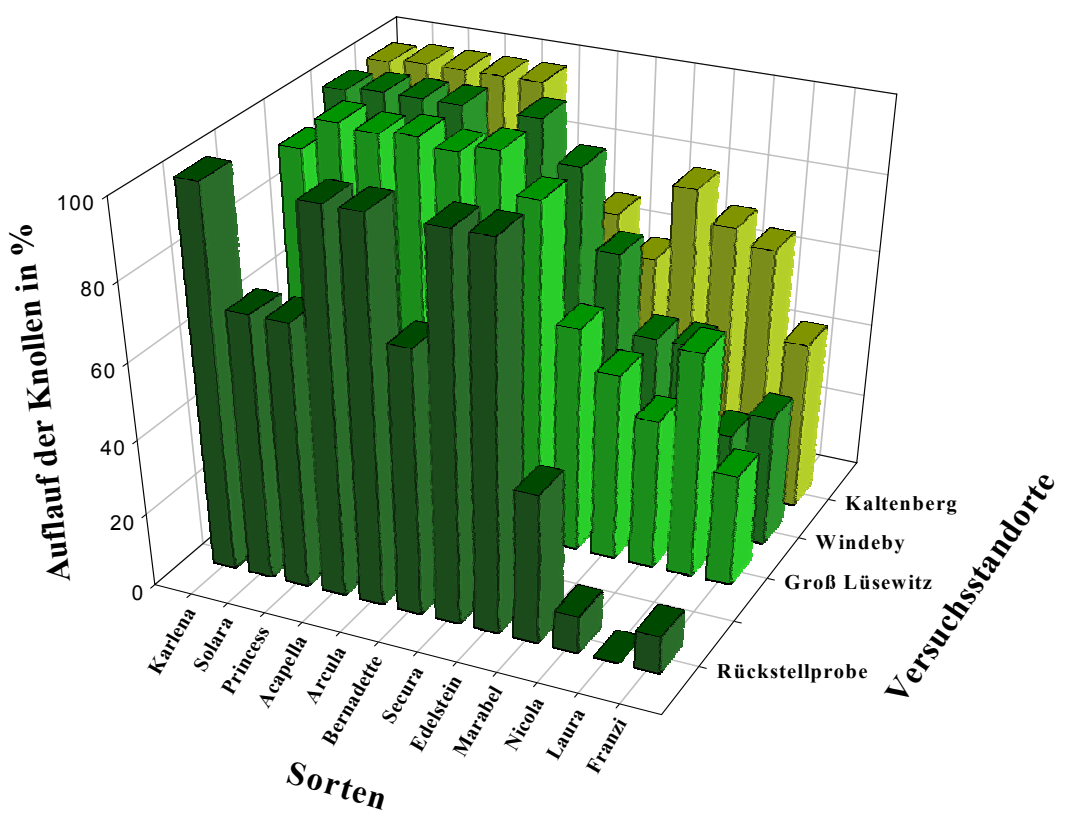

Graphik 5: Aufgang der Sorten im Versuchsjahr 2002. Auf der $x$-Achse sind die Sorten, auf der y-Achse der Auflauf der Knollen in \% und auf der z-Achse die Standorte dargestellt. Es zeigten immer die gleichen Sorten an allen drei Standorten wie auch der Rückstellprobe starke Probleme im Aufgang.

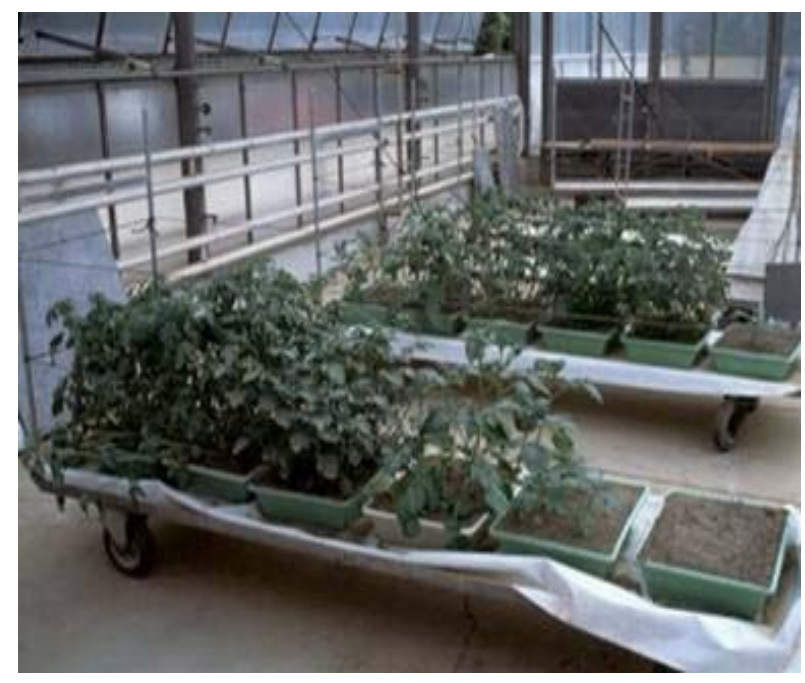

Abbildung 7: Aufgang der Knollen der Rückstellprobe im Gewächshaus im Versuchsjahr 2002. Der Aufgang war dem der Knollen im Feld äquivalent. Die Sorten Franzi und Laura zeigten große Lücken (vordere Pflanzkästen).

Dabei zeigten die Sorten Franzi und Laura, die schon im Feld Auflaufprobleme aufwiesen, auch im Gewächshaus lückenhaften Aufgang. Es wurde eine Korrelation zwischen dem Auflaufverhalten im Feld und dem im Gewächshaus errechnet (Graphik $6)$. 


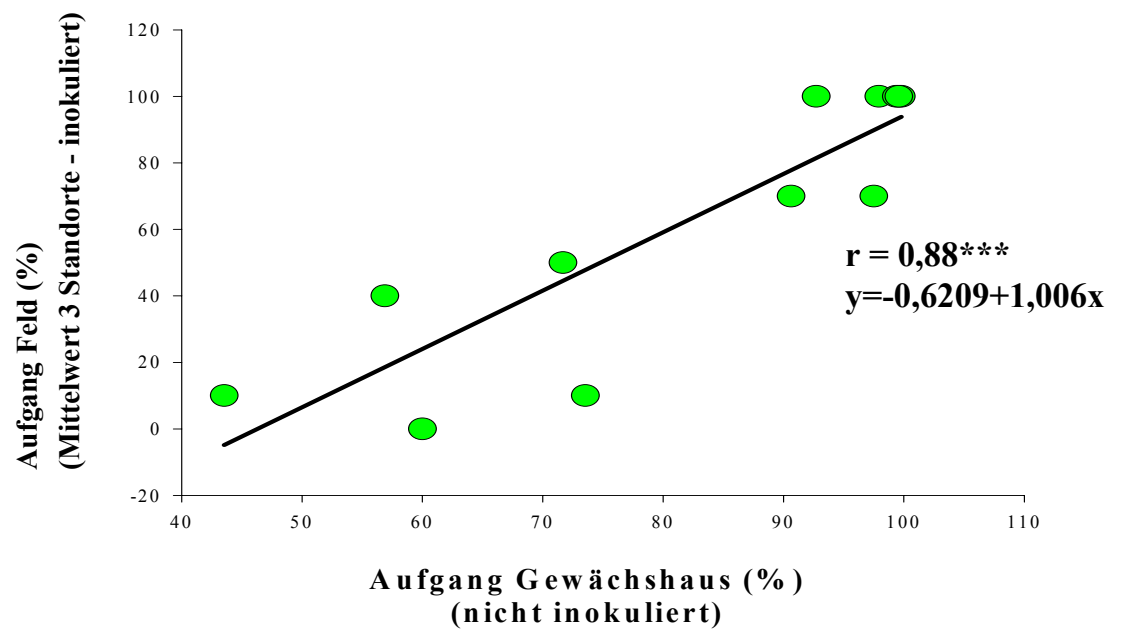

Graphik 6: Korrelation zwischen Aufgang der Sorten in den Feldversuchen und im Gewächshaus. Auf der x-Achse ist der Aufgang im Gewächshaus, auf der y-Achse der im Feld dargestellt. Der Korrelationskoeffizient beträgt $0,88^{* * *}$, der Durbin-Watson-Test zeigt eine signifikante Beziehung zwischen den beiden Parametern.

Es wurde im Durbin-Watson-Test mit $\mathrm{r}=0,88 * * *$ eine starke Korrelation errechnet, womit die Inokulation als auslösender Faktor ausschied. Die Wetterverhältnisse 2002 waren an den drei Standorten sehr unterschiedlich (Graphiken 7 -9).

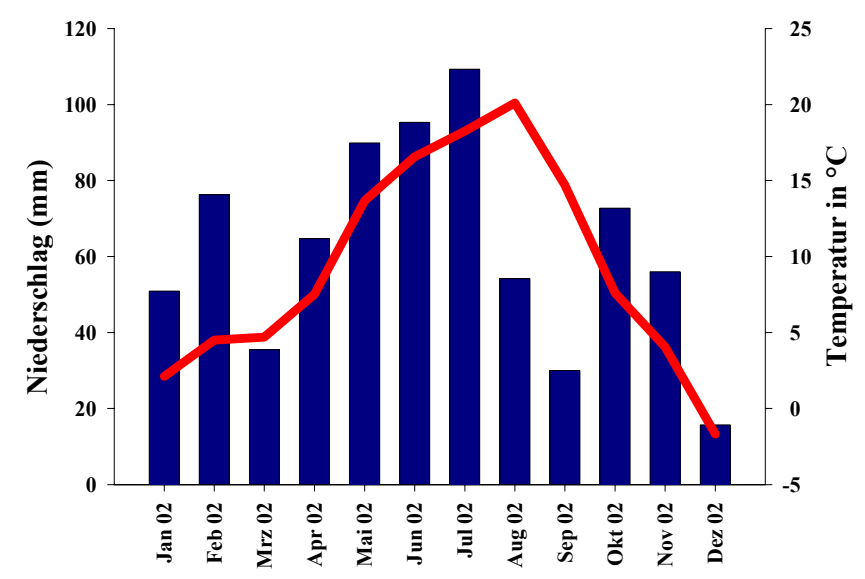

Graphik 7: Witterungsverlauf am Standort Groß Lüsewitz 2002. Auf der x-Achse ist der Jahresverlauf dargestellt, auf der linken y-Achse der Niederschlag in mm (Säulen) und auf der rechten y-Achse die Temperatur in ${ }^{\circ} \mathrm{C}$ (Kurve). 


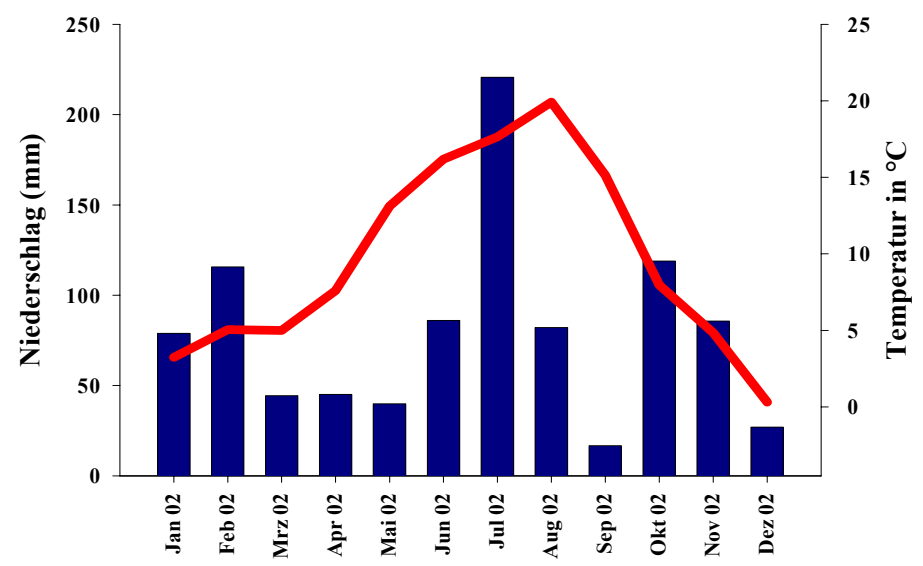

Graphik 8: Witterungsverlauf am Standort Windeby 2002. Auf der $x$-Achse ist der Jahresverlauf dargestellt, auf der linken y-Achse der Niederschlag in mm (Säulen) und auf der rechten y-Achse die Temperatur in ${ }^{\circ} \mathrm{C}$ (Kurve).

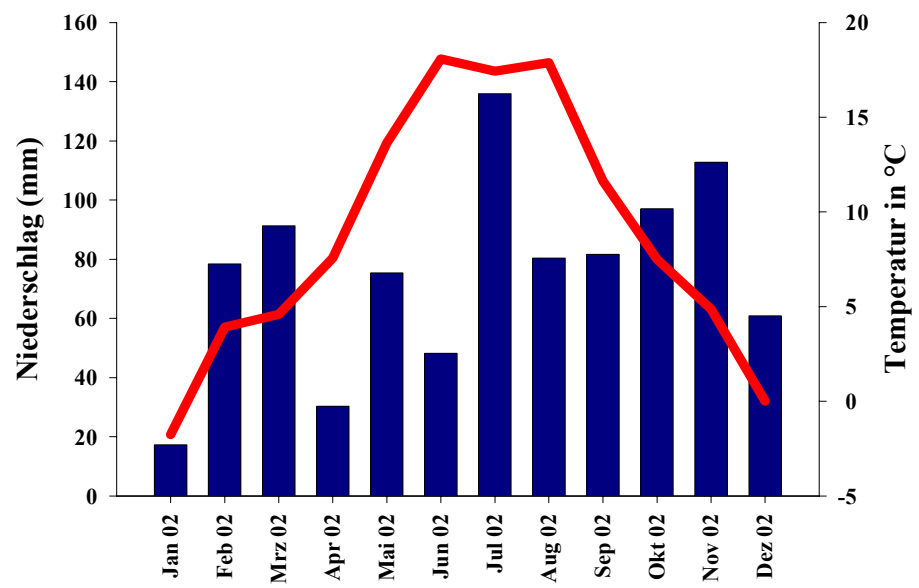

Graphik 9: Witterungsverlauf am Standort Kaltenberg 2002. Auf der x-Achse ist der Jahresverlauf dargestellt, auf der linken y-Achse der Niederschlag in mm (Säulen) und auf der rechten y-Achse die Temperatur in ${ }^{\circ} \mathrm{C}$ (Kurve).

Während in Kaltenberg über das ganze Jahr überdurchschnittliche Regenmengen fielen und dadurch die Sonneneinstrahlung auch gering war, blieben die Regenereignisse in Groß Lüsewitz und Windeby normal. Nach der Ernte wurden die Knollen wie beschrieben bonitiert. Alle Sorten zeigten an allen drei Standorten einen geringen Silberschorfbefall (Graphiken 10 - 12). 


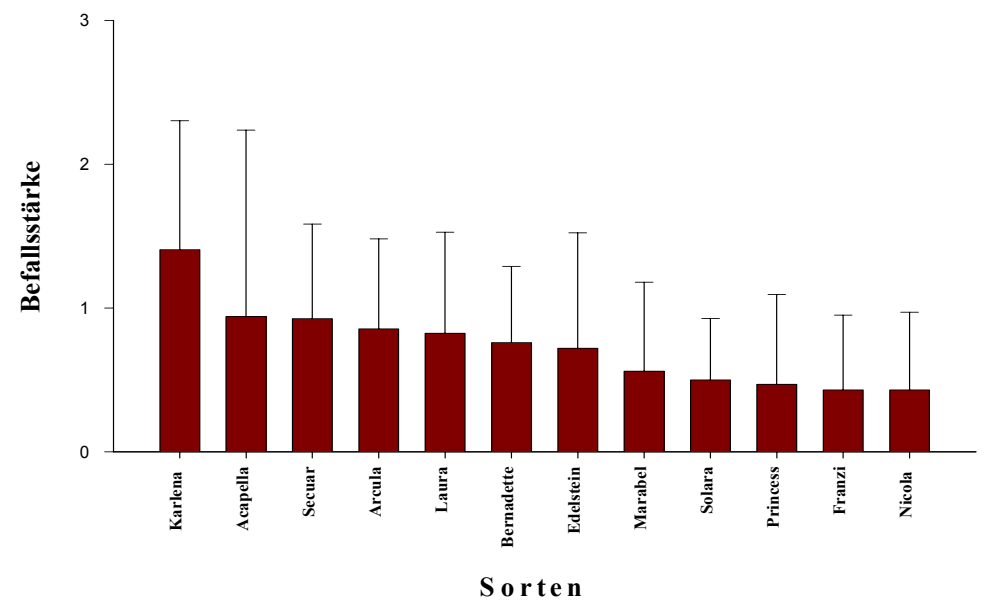

Graphik 10: Befall der Knollen nach der Ernte mit $\boldsymbol{H}$. solani am Standort Groß Lüsewitz 2002. Auf der $x$-Achse sind die Sorten dargestellt, auf der y-Achse die Befallsstärke von 0-3 (vgl. Kapitel 6 aus Material und Methoden). Die Intervalle geben Standardabweichungen der 50 bonitierten Knollen wieder. Alle Sorten zeigten einen Befall.

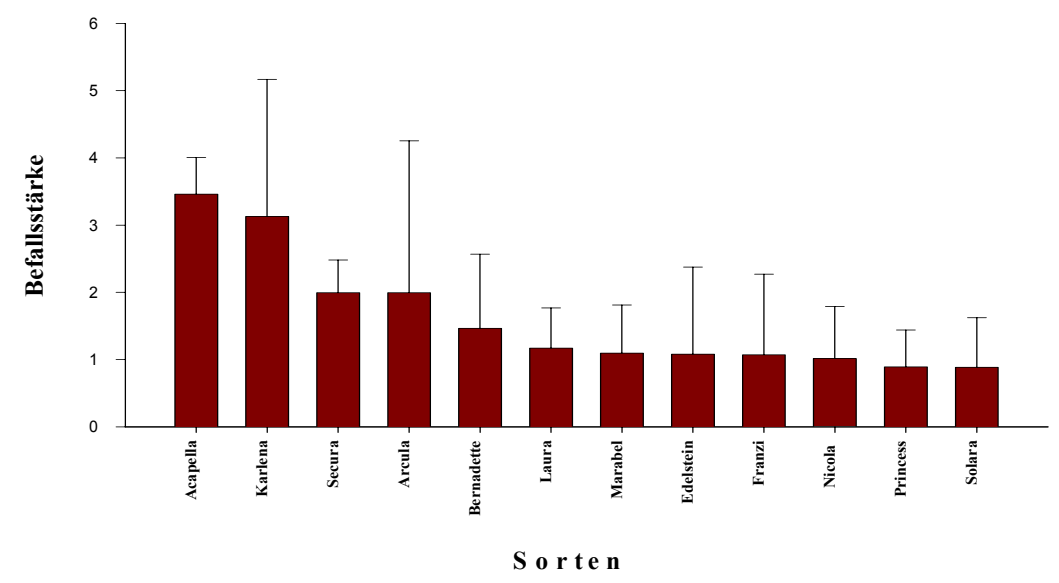

Graphik 11: Befall der Knollen nach der Ernte mit H. solani am Standort Windeby 2002. Auf der x-Achse sind die Sorten dargestellt, auf der y-Achse die Befallsstärke von 0-6 (vgl. Kapitel 6 aus Material und Methoden). Die Intervalle geben Standardabweichungen der 50 bonitierten Knollen wieder. Alle Sorten zeigten einen Befall.

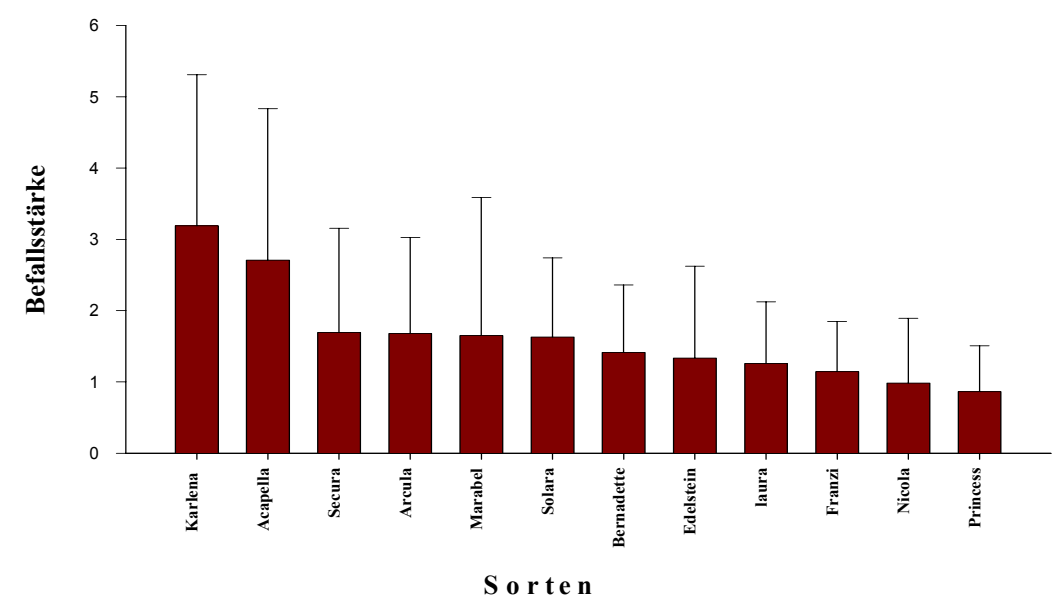

Graphik 12: Befall der Knollen nach der Ernte mit $\boldsymbol{H}$. solani am Standort Kaltenberg 2002. Auf der x-Achse sind die Sorten dargestellt, auf der y-Achse die Befallsstärke von 0-6 (vgl. Kapitel 6 aus Material und Methoden) Die Intervalle geben Standardabweichungen der 50 bonitierten Knollen wieder. Alle Sorten zeigten einen Befall. 
Dabei zeigten im ersten Jahr die Knollen vom Standort Kaltenberg und Windeby (Graphik 11 und 12) einen höheren Befall auf als in Groß Lüsewitz. Die Sorten Karlena, Acapella, Arcula und Secura wiesen im ersten Jahr an allen drei Standorten die meisten Symptome auf, während Princess, Franzi, und Nicola eine geringe Anfälligkeit zeigten. Die Sorten Laura, Solara, Marabel, Bernadette, und Edelstein schwankten in der Symptomausprägung leicht von Standort zu Standort, verblieben aber stets im mittleren Anfälligkeitsbereich. Insgesamt war der Silberschorfbefall direkt nach der Ernte an allen drei Standorten sehr gering, was darauf zurückzuführen ist, dass die Krankheit sich hauptsächlich im Lager ausbreitet. Neben Silberschorf wurde auch der Befall von C. coccodes ermittelt (Graphik 13).

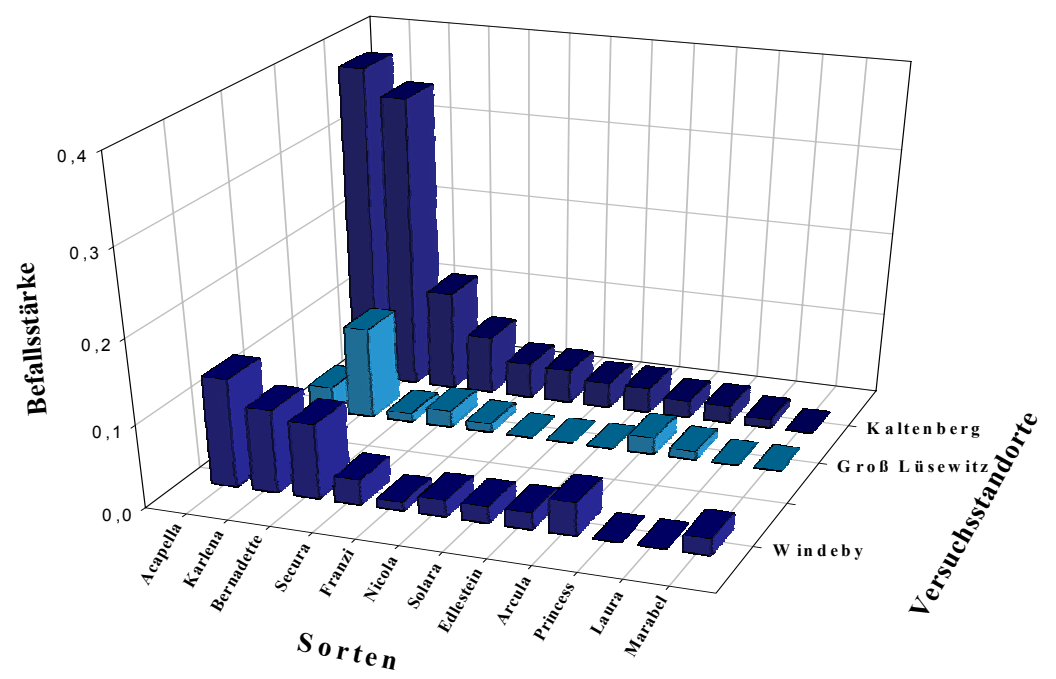

Graphik 13: $C$. coccodes Befall der Knollen nach der Ernte 2002 an allen drei Standorten. Auf der x-Achse sind die Sorten, auf der y-Achse die Befallsstärke von 0-0,4 (vgl. Kapitel 6 aus Material und Methoden) und auf der z-Achse die Standort dargestellt. Der Befall ist sehr gering und variiert stark von Standort zu Standort.

Da es sich hierbei ebenfalls um eine Schalenerkrankung der Knollen handelt, wurde eine Konkurrenz vermutet. Insgesamt war der Befall mit $C$. coccodes direkt nach der Ernte im Vergleich zu Silberschorf sehr gering. Die Befallsstärke an den Standorten schwankte leicht, auch die Anfälligkeit der Sorten änderte sich von Standort zu Standort. Nur die Sorten Karlena und Acapella waren an allen drei Standorten die anfälligsten auf $C$. coccodes. Nach dem Durbin-Watson-Test konnte keine signifikante Beziehung zwischen dem Befall mit Silberschorf und dem mit $C$. coccodes gefunden werden.

Da es sich bei Silberschorf um eine Krankheit handelt, die sich hauptsächlich im Lager ausbreitet, wurden die Knollen der Standorte Groß Lüsewitz (Graphik 14) und Windeby (Graphik 15), sowie eine Kontrolle des Bundessortenamtes (Graphik 16) wie in Kapitel 
10 aus Material und Methoden beschrieben eingelagert und im ersten Versuchsjahr nach 8, 10 und 12 Wochen auf Silberschorf bonitiert.

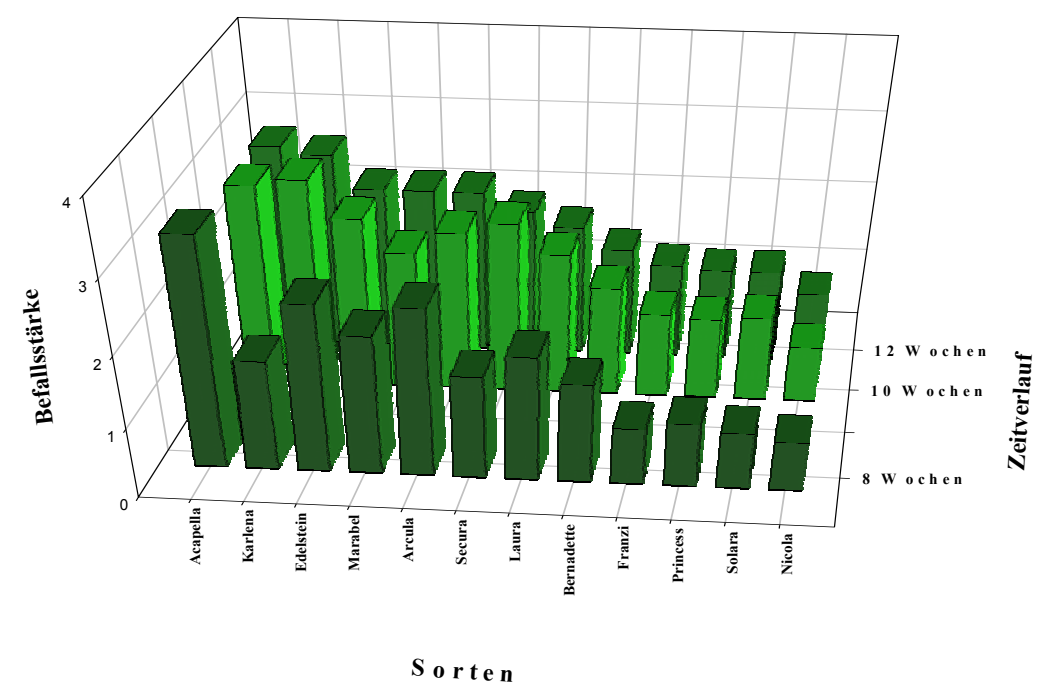

Graphik 14: $H$. solani Befallsverlauf nach Lagerung der Knollen aus dem Feldversuch Groß Lüsewitz 2002. Auf der $x$-Achse sind die Knollen dargestellt, auf der y-Achse die Befallsstärke von 1-4 (vgl. Kapitel 6 aus Material und Methoden) und auf der z-Achse der zeitliche Verlauf. Die Knollen wurden im Dunkeln bei $20^{\circ} \mathrm{C}$ und $90^{\circ}$ Luftfeuchte gelagert und nach 8,10 und 12 Wochen wie beschrieben auf Silberschorf überprüft.

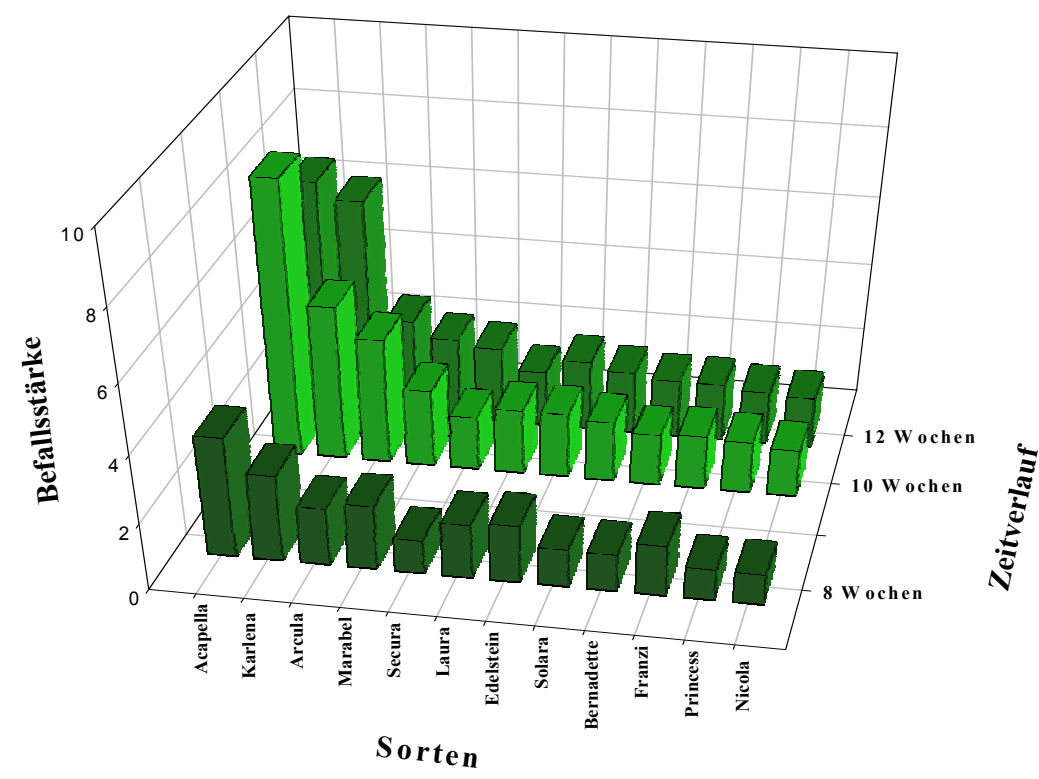

Graphik 15: $H$. solani Befallsverlauf nach Lagerung der Knollen aus dem Feldversuch Windeby 2002. Auf der $x$-Achse sind die Knollen dargestellt, auf der $y$-Achse die Befallsstärke von 1-10 (vgl. Kapitel 6 aus Material und Methoden) und auf der z-Achse der zeitliche Verlauf. Die Knollen wurden im Dunkeln bei $20^{\circ} \mathrm{C}$ und $90^{\circ}$ Luftfeuchte gelagert und nach 8, 10 und 12 Wochen wie beschrieben auf Silberschorf überprüft. 


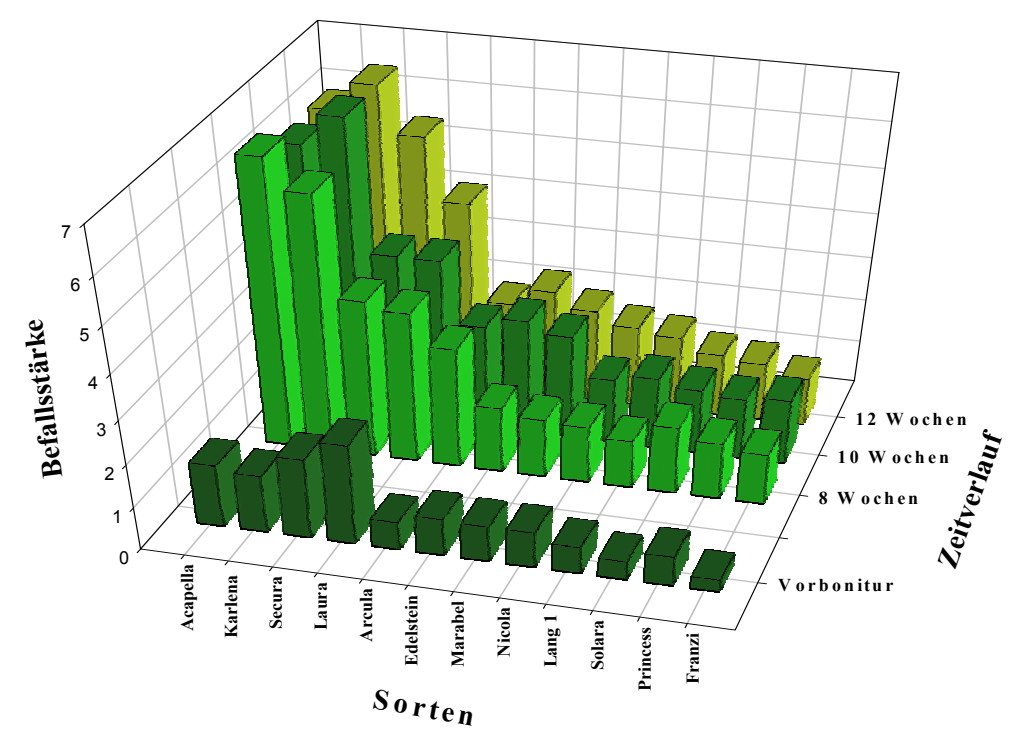

Graphik 16: H. solani Befallsverlauf nach Lagerung der Knollen des Bundessortenamtes 2002. Auf der $x$-Achse sind die Knollen dargestellt, auf der $y$-Achse die Befallsstärke von 1-7 (vgl. Kapitel 6 aus Material und Methoden) und auf der z-Achse der zeitliche Verlauf. Die Knollen wurden im Dunkeln bei $20^{\circ} \mathrm{C}$ und $90^{\circ}$ Luftfeuchte gelagert und nach 8, 10 und 12 Wochen wie beschrieben auf Silberschorf überprüft.

Der Befall der Knollen stieg in allen Einlagerungsversuchen sortenabhängig stark, eine Veränderung der Anfälligkeit der verschiedenen Sorten während der Lagerung konnte in keinem Versuch beobachtet werden. Nach der Lagerung war die Befallsstärke bei allen Sorten an allen Standorten gestiegen. Der Silberschorfbefall war am Standort Windeby am höchsten. Bei den nach der Ernte als anfällig eingestuften Knollen der Sorten Karlena, Acapella, Arcula und Secura war bei allen drei Versuchen der Anteil befallener Knollenoberfläche am stärksten gestiegen, so dass teilweise bei einzelnen Knollen bis zu 100\% der Knollenoberfläche mit Silberschorf bedeckt war. Die Sorten Nicola, Princess und Franzi dagegen zeigten in allen drei Lagerversuchen nur einen leichten Befallsanstieg, wobei selten auf mehr als 30\% der Kartoffeloberfläche ein Befall mit H. solani nachgewiesen wurde. Die Sorten Laura, Marabel und Solara, Edelstein und Bernadette schwankten in ihrer Anfälligkeit wie nach der Ernte im mittleren Anfälligkeitsbereich. Um die Beziehung der Feld- und Lagerversuche zu untersuchen, wurden Regressionen zwischen den verschiedenen Feld und Lagerversuchen errechnet. (Tab. 9). 
Tabelle 9: Regressionen der Anfälligkeit der Sorten auf $\boldsymbol{H}$. solani zwischen den Feld- und Lagerversuchen 2002. Die Ergebnisse der Ernte- und Lagerergebnisse aus dem Versuchsjahr 2002 wurden miteinander in Beziehung gesetzt. Das Bestimmtheitsmaß betrug in allen Fällen 0,34 oder höher. Die Signifikanzen lagen stets zwischen $p<0,05$ und $p<0,01$. Es besteht eine signifikante Beziehung zwischen allen Parametern.

\begin{tabular}{|l|c|l|c|l|l|}
\hline & $\begin{array}{l}\text { Windeby } \\
\text { Ernte 2002 }\end{array}$ & $\begin{array}{l}\text { Groß } \\
\text { Lüsewitz } \\
\text { Ernte 2002 }\end{array}$ & $\begin{array}{l}\text { Kaltenberg } \\
\text { Ernte 2002 }\end{array}$ & $\begin{array}{l}\text { Windeby } \\
\text { Lager 2002 }\end{array}$ & $\begin{array}{l}\text { Groß } \\
\text { Lüsewitz } \\
\text { Lager 2002 }\end{array}$ \\
\hline $\begin{array}{l}\text { Groß } \\
\text { Lüsewitz } \\
\text { Ernte 2002 }\end{array}$ & $0,69^{* * *}$ & & & & \\
\hline $\begin{array}{l}\text { Kaltenberg } \\
\text { Ernte 2002 }\end{array}$ & $0,77^{* * *}$ & $0,51 * * *$ & & & \\
\hline $\begin{array}{l}\text { Windeby } \\
\text { Lager 2002 }\end{array}$ & $0,62^{* * *}$ & $0,39^{* *}$ & $0,55^{* *}$ & & \\
\hline $\begin{array}{l}\text { Groß } \\
\text { Lüsewitz } \\
\text { Lager 2002 }\end{array}$ & $0,73^{* * *}$ & $0,77^{* * *}$ & $0,59^{* * *}$ & $0,48^{* *}$ & \\
\hline $\begin{array}{l}\text { Bundes- } \\
\text { sortenamt } \\
\text { Lager 2002 }\end{array}$ & $0,70^{* * *}$ & $0,69^{* * *}$ & $0,52^{* * *}$ & $0,34^{* *}$ & $0,69 * * *$ \\
\hline
\end{tabular}

Das Bestimmtheitmass war bei allen Vergleichen $\geq 0,34$. Die Signifikanzen lagen stets zwischen $\mathrm{p}<0,05$ oder $\mathrm{p}<0,01$. Dies bestätigte eine signifikante Beziehung der Anfälligkeiten der Sorten auf $H$. solani aller Versuche unabhängig von äußeren Einflüssen zueinander. Die Anfälligkeit der Knollen auf $H$. solani ist somit sortenabhängig zu sein. Nach 12 Wochen Einlagerung wurde der C. coccodes Befall ebenfalls untersucht (Graphiken 17).

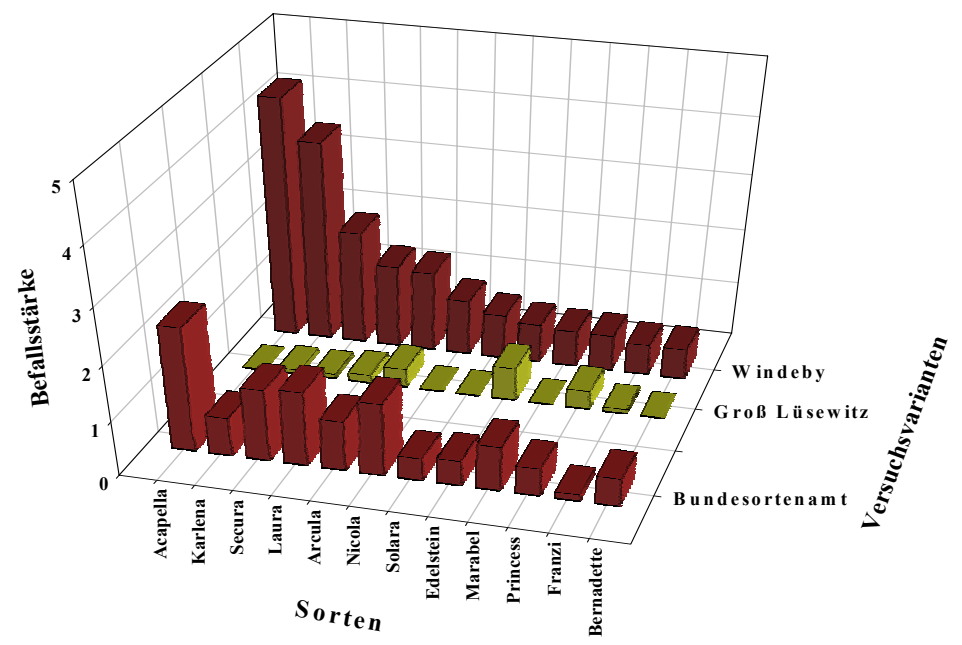

Graphik 17: C. coccodes Befall der Knollen nach Lagerung für 12 Wochen 2002. Auf der XAchse sind die Sorten, auf der y-Achse die Befallsstärke (vgl. Kapitel 6 aus Material und Methoden) und auf der z-Achse die Versuchsvarianten dargestellt. Die Knollen wurden im Dunkeln bei $20^{\circ} \mathrm{C}$ und $90^{\circ}$ Luftfeuchte gelagert und nach 8,10 und 12 Wochen wie beschrieben auf $C$. coccodes überprüft. 
Die Sorten Acapella und Karlena zeigten sich wie schon nach der Ernte als anfällig, während die anderen Sorten von Versuch zu Versuch schwankten. Auch für $C$. coccodes wurden Regressionen zwischen den Feld- und Lagerversuchen errechnet (Tab. $10)$.

Tabelle 10: Regressionen der Anfälligkeit der Sorten auf $C$. coccodes zwischen den Feldund Lagerversuchen 2002. Die Ergebnisse der Ernte- und Lagerergebnisse aus dem Versuchsjahr 2002 wurden miteinander in Beziehung gesetzt. Das Bestimmtheitsmaß schwankte zwischen 0,02 und 0,86. Die Signifikanzen lagen zwischen $p<0,01$ und $p<0,10$. Es konnte keine eindeutig signifikante Beziehung zwischen den Parametern insgesamt festgestellt werden.

\begin{tabular}{|l|c|c|l|l|l|}
\hline & $\begin{array}{l}\text { Windeby } \\
\text { Ernte 2002 }\end{array}$ & $\begin{array}{l}\text { Kaltenberg } \\
\text { Ernte 2002 }\end{array}$ & $\begin{array}{l}\text { Groß } \\
\text { Lüsewitz } \\
\text { Ernte 2002 }\end{array}$ & $\begin{array}{l}\text { Bundes- } \\
\text { sortenamt } \\
\text { Lager 2002 }\end{array}$ & $\begin{array}{l}\text { Groß } \\
\text { Lüsewitz } \\
\text { Lager 2002 }\end{array}$ \\
\hline $\begin{array}{l}\text { Groß } \\
\text { Lüsewitz } \\
\text { Ernte 2002 }\end{array}$ & $0,46^{* *}$ & & & & $\cdot$ \\
\hline $\begin{array}{l}\text { Kaltenberg } \\
\text { Ernte 2002 }\end{array}$ & $0,72^{* * *}$ & $0,66^{* * *}$ & & & \\
\hline $\begin{array}{l}\text { Windeby } \\
\text { Lager 2002 }\end{array}$ & $0,31^{*}$ & 0,07 n.s. & $0,34^{* *}$ & & \\
\hline $\begin{array}{l}\text { Groß } \\
\text { Lüsewitz } \\
\text { Lager 2002 }\end{array}$ & 0,06 n.s. & 0,02 n.s. & 0,05 n.s. & 0,07 n.s. & \\
\hline $\begin{array}{l}\text { Bundes- } \\
\text { sortenamt } \\
\text { Lager 2002 }\end{array}$ & $0,48^{* *}$ & $0,60^{* * *}$ & $0,86^{* * *}$ & $0,38^{* *}$ & 0,06 n.s. \\
\hline
\end{tabular}

Die Beziehungen der Anfälligkeit der Knollen auf $C$. coccodes zu den jeweiligen Genotypen waren in einigen Fällen ebenfalls signifikant $(p<0,05$ oder $p<0,01)$, in anderen jedoch nicht signifikant $(\mathrm{p}<0,10)$. Eine eindeutige Beziehung der Anfälligkeit mit den entsprechenden Sorten konnte daher nicht nachgewiesen werden. Es wurden ebenfalls Regressionen zwischen den Ergebnissen der Bonituren auf Silberschorf und $C$. coccodes errechnet (Tabelle 11). 
Tabelle 11: Regressionen zwischen dem Befall der Sorten mit Silberschorf und $C$. coccodes der Feld- und Lagerversuche 2002. Die Ergebnisse der Ernte- und Lagerergebnisse aus dem Versuchsjahr 2002 wurden miteinander in Beziehung gesetzt. Das Bestimmtheitsmaß schwankte zwischen 0,001 und 0,90. Die Signifikanzen lagen zwischen $p<0,01$ und $p<0,10$. Es konnte somit keine eindeutig signifikante Beziehung zwischen den Parametern insgesamt festgestellt werden.

\begin{tabular}{|c|c|c|c|c|c|c|}
\hline & $\begin{array}{c}\text { C. coccodes } \\
\text { Windeby } \\
\text { Ernte 2002 }\end{array}$ & $\begin{array}{c}\text { C. coccodes } \\
\text { Kaltenberg } \\
\text { Ernte 2002 }\end{array}$ & $\begin{array}{c}\text { C. coccodes } \\
\text { Groß } \\
\text { Lüsewitz } \\
\text { Ernte 2002 }\end{array}$ & $\begin{array}{c}\text { C. coccodes } \\
\text { Groß } \\
\text { Lüsewitz } \\
\text { Lager 2002 }\end{array}$ & $\begin{array}{c}\text { C. coccodes } \\
\text { Windeby } \\
\text { Lager 2002 }\end{array}$ & $\begin{array}{c}\text { C. coccodes } \\
\text { BSA } \\
\text { Lager 2002 }\end{array}$ \\
\hline $\begin{array}{c}\text { Silberschorf } \\
\text { Groß } \\
\text { Lüsewitz } \\
\text { Ernte 2002 }\end{array}$ & $0,50 * *$ & $0,40^{* *}$ & $0,69 * * *$ & 0,002 n.s. & $0,59 * * *$ & 0,08 n.s. \\
\hline $\begin{array}{c}\text { Silberschorf } \\
\text { Kaltenberg } \\
\text { Ernte 2002 }\end{array}$ & $0,38^{* *}$ & $0,75^{* * *}$ & $0,56^{* * *}$ & 0,04 n.s. & $0,90 * * *$ & $0,35 * *$ \\
\hline $\begin{array}{c}\text { Silberschorf } \\
\text { Windeby } \\
\text { Ernte 2002 }\end{array}$ & $0,71^{* * *}$ & $0,61^{* * *}$ & $0,63 * * *$ & 0,08 n.s. & $0,71 * * *$ & 0,14 n.s. \\
\hline $\begin{array}{c}\text { Silberschorf } \\
\text { Groß } \\
\text { Lüsewitz } \\
\text { Lager 2002 }\end{array}$ & $0,77 * * *$ & $0,65^{* * *}$ & $0,27 *$ & 0,01 n.s. & $0,84 * * *$ & $0,45^{* *}$ \\
\hline $\begin{array}{c}\text { Silberschorf } \\
\text { Windeby } \\
\text { Lager 2002 }\end{array}$ & $0,38^{* *}$ & $0,35^{* *}$ & $0,39 * *$ & 0,001 n.s. & $0,51 * * *$ & 0,12 n.s. \\
\hline $\begin{array}{c}\text { Silberschorf } \\
\text { Bundes- } \\
\text { sortenamt } \\
\text { Lager 2002 }\end{array}$ & $0,69 * * *$ & $0,45^{* *}$ & $0,58^{* * *}$ & 0,02 n.s. & $0,88^{* * *}$ & $0,33 *$ \\
\hline
\end{tabular}

Das Bestimmtheitsmaß schwankte zwischen 0,001 und 0,90. Die Beziehungen des Befalls der Knollen mit Silberschorf zu dem mit $C$. coccodes waren in einigen Fällen ebenfalls signifikant ( $\mathrm{p}<0,05$ oder $\mathrm{p}<0,01)$, in anderen jedoch nicht signifikant $(\mathrm{p}<$ 0,10). Daher konnte keine eindeutige Beziehung zwischen dem Befall der Knollen mit den beiden Krankheiten nachgewiesen werden. Da der Befall mit $C$. coccodes jedoch in allen Fällen insgesamt nur sehr gering im Vergleich zu Silberschorf war und zwischen den Standorten stark schwankte, war ein Vergleich nur bedingt möglich. 
Im zweiten Versuchsjahr wurden die Pflanzknollen wiederum von den sechs deutschen Züchterhäusern zur Verfügung gestellt und stammten wie im Vorjahr aus unterschiedlichen, unbekannten Lagerherkünften. Bei der Vorbonitur der Pflanzknollen hatten ebenfalls alle Sorten einen geringen Vorbefall mit H. solani (Graphik 18).

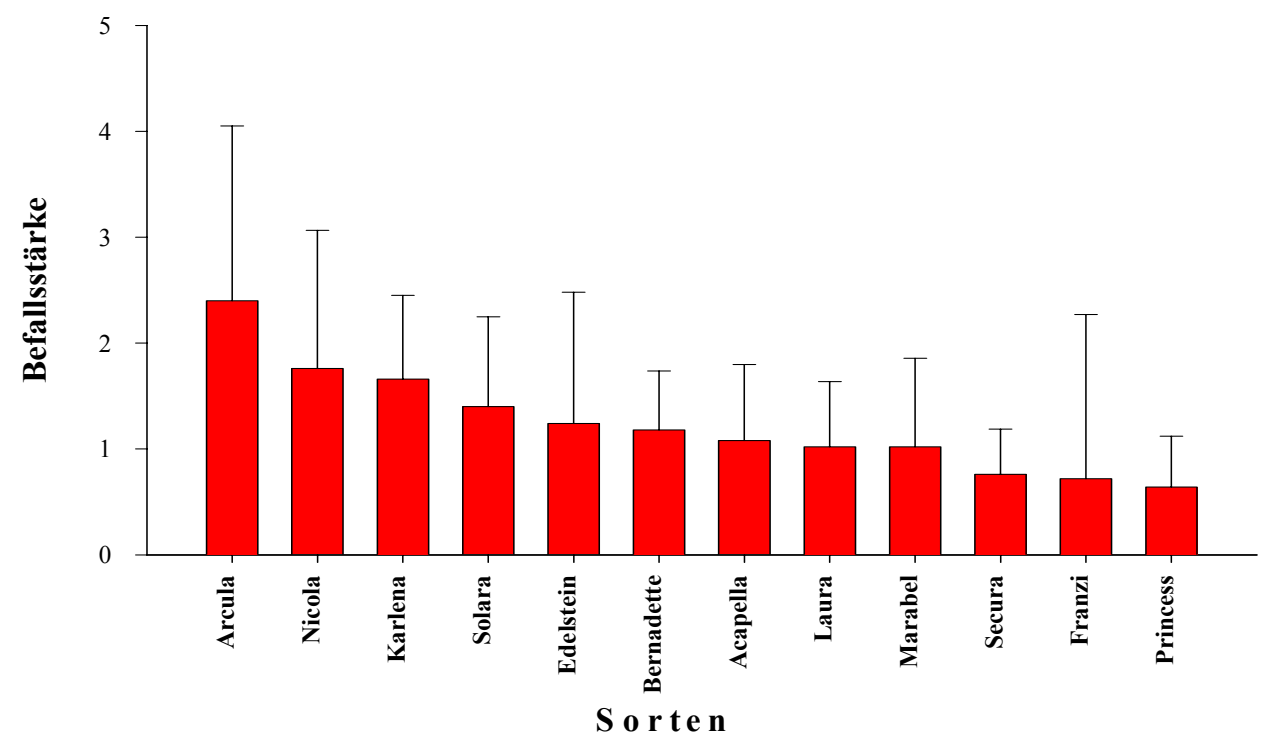

Graphik 18: Vorbefall der Pflanzknollen mit $\boldsymbol{H}$. solani im Versuchsjahr 2003. Auf der xAchse sind die Sorten dargestellt, auf der y-Achse die Befallsstärke von 1-5 (vgl. Kapitel 6 aus Material und Methoden). Die Intervalle geben Standardabweichungen der 50 bonitierten Knollen wieder. Wiederum zeigten alle Sorten einen Vorbefall.

Da das Pflanzgut je nach Sorte aus unterschiedlichen Lagerbedingungen stammte, und somit keine einheitlichen Anfangsbedingungen vorlagen, wurden im zweiten Versuchsjahr die Versuchsparzellen geteilt und nur eine Hälfte inokuliert. Durch die Inokulation nur einer Hälfe des Versuches war die Unterscheidung zwischen hohem und niedrigem Befallsdruck im zweiten Jahr somit auch im Feld simuliert. Die Beziehungen der Anfälligkeit der Knollen auf $C$. coccodes zu den jeweiligen Genotypen waren in einigen Fällen ebenfalls stark $(\mathrm{p}<0,05$ oder $\mathrm{p}<0,01)$, in anderen jedoch nicht signifikant $(\mathrm{p}<0,10)$.

Das Auflaufen der Pflanzen stellte im Jahr 2003 keinerlei Probleme dar, 6 Wochen nach Legen der Knollen waren an allen drei Standorten 90-100 \% aller Pflanzen aufgelaufen. Auch die Rückstellprobe im Gewächshaus lief problemlos zu $100 \%$ auf.

Im Jahr 2003 waren die Wetterverhältnisse an den drei Standorten wiederum sehr unterschiedlich (Graphiken 19 - 21). Während in Kaltenberg eine Trockenperiode folgte, waren die Niederschlagsmengen in Windeby und Groß Lüsewitz durchschnittlich. 


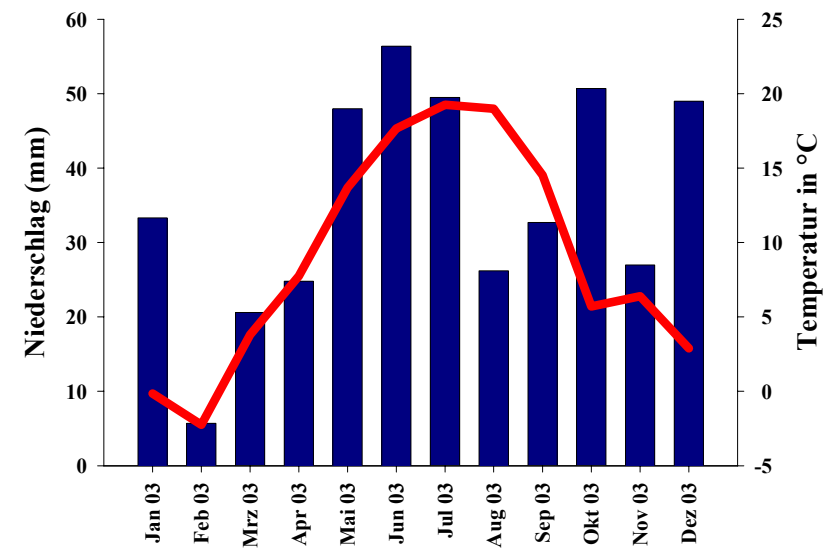

Graphik 19: Witterungsverhältnisse am Standort Groß Lüsewitz 2003. Auf der x-Achse sind ist der Jahresverlauf dargestellt, auf der linken y-Achse der Niederschlag in mm (Säulen) und auf der rechten y-Achse die Temperatur in ${ }^{\circ} \mathrm{C}$ (Kurve).

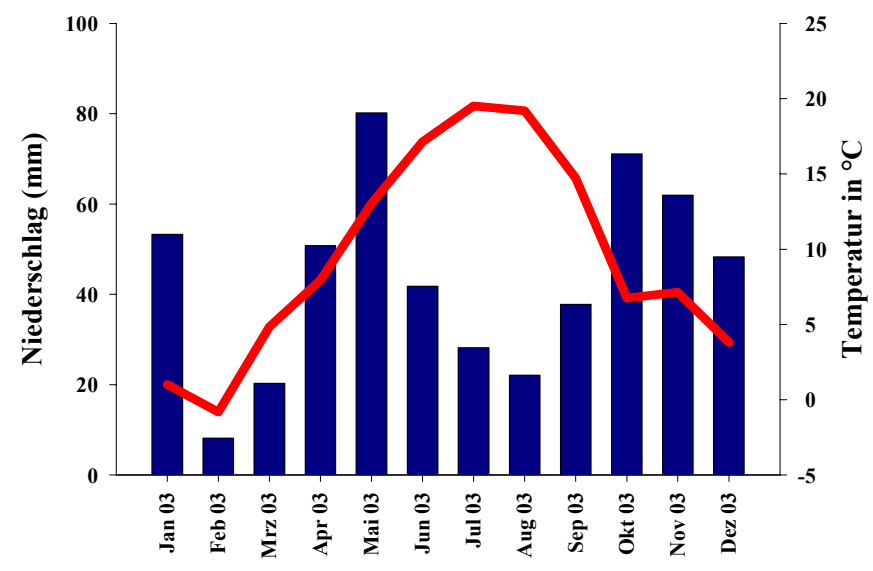

Graphik 20: Witterungsverhältnisse am Standort Windeby 2003. Auf der $x$-Achse ist der Jahresverlauf dargestellt, auf der linken y-Achse der Niederschlag in mm (Säulen) und auf der rechten y-Achse die Temperatur in ${ }^{\circ} \mathrm{C}$ (Kurve).

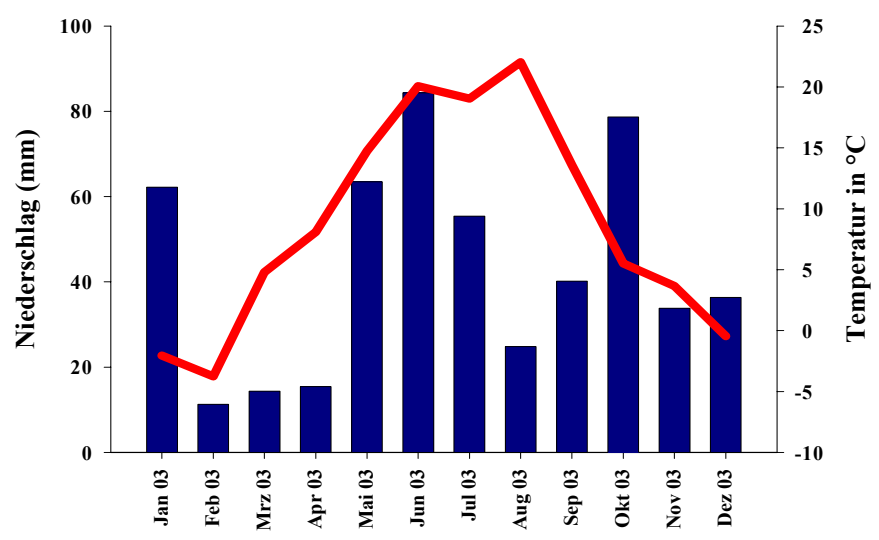

Graphik 21: Witterungsverhältnisse am Standort Kaltenberg 2003. Auf der x-Achse ist der Jahresverlauf dargestellt, auf der linken y-Achse der Niederschlag in mm (Säulen) und auf der rechten y-Achse die Temperatur in ${ }^{\circ} \mathrm{C}$ (Kurve). 
Im zweiten Versuchsjahr wurde zudem die Höhe der Pflanzen im EC-Stadium 65 gemessen. Die Pflanzenhöhe der Versuchsparzellen schwankte sehr stark sortenabhängig, wobei Parzellen der gleichen Sorten immer in etwa die gleiche Höhe aufwiesen. Es wurden Signifikanzen zwischen unbehandelten und inokulierten Parzellen errechnet, es konnten jedoch keine signifikanten Unterschiede zwischen den inokulierten und den unbehandelten Parzellen festgestellt werden (Graphiken 22 - 24).

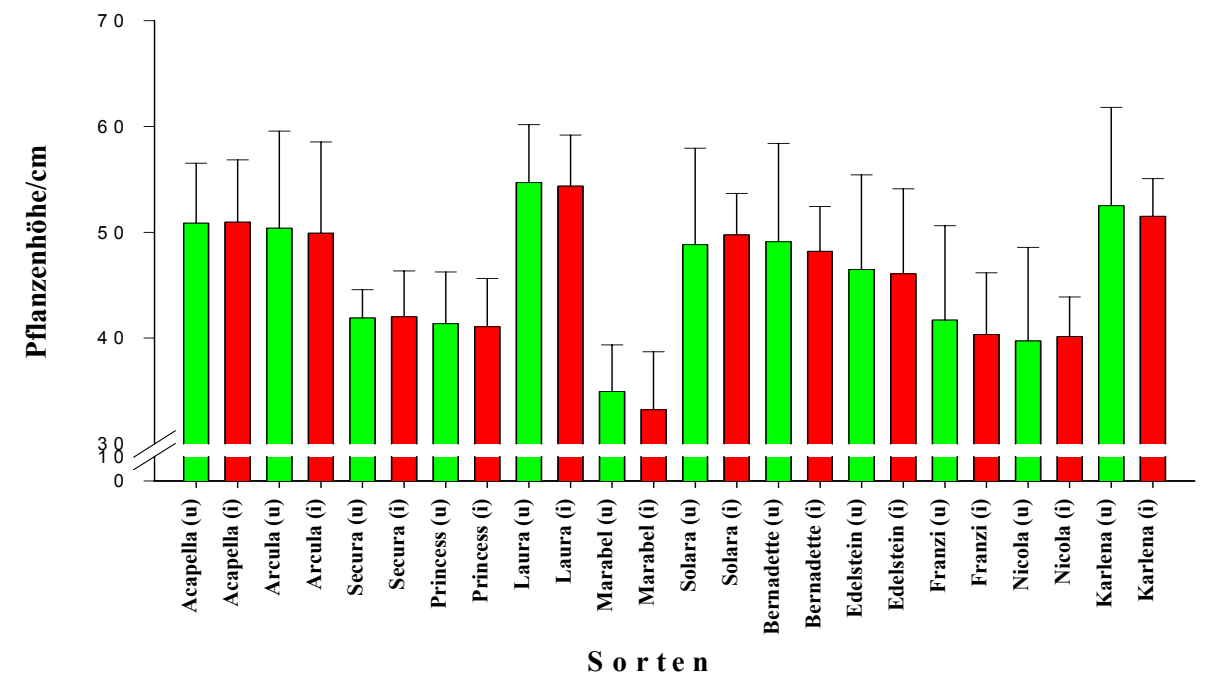

n.S.

Graphik 22: Pflanzenhöhe in den Versuchsparzellen in Groß Lüsewitz 2003. Alle Pflanzen wurden im EC-Stadium 65 vermessen. Auf der x-Achse sind die Sorten, auf der y-Achse die Höhe der Pflanzen in $\mathrm{cm}$ angegeben. $\mathrm{u}=$ =unbehandelte; $\mathrm{i}=$ inokuliert; Die Intervalle geben Standardabweichungen der gemessenen Pflanzen an. Es wurden keine signifikanten Unterschiede zwischen den Varianten gefunden (n.s.: nicht signifikant nach $\mathrm{t}-$ Test, $\mathrm{p} \leq 0,05$ ).

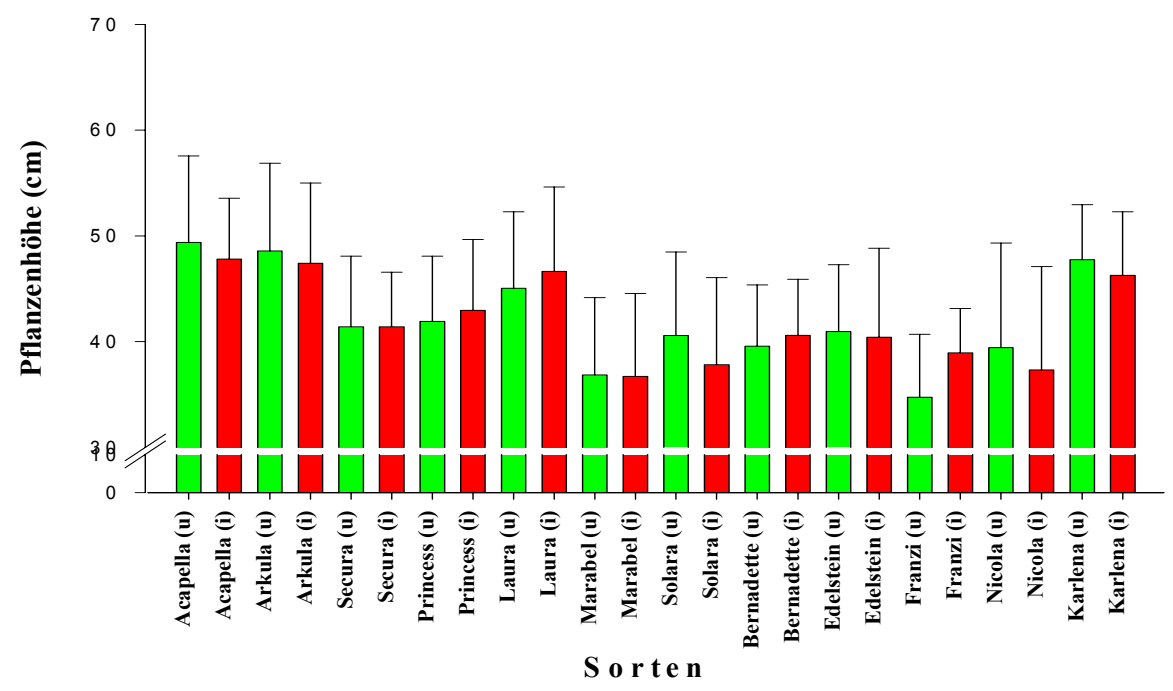

n.S.

Graphik 23: Pflanzenhöhe in den Versuchsparzellen in Windeby 2003. Alle Pflanzen wurden im EC-Stadium 65 vermessen. Auf der x-Achse sind die Sorten, auf der y-Achse die Höhe der Pflanzen in $\mathrm{cm}$ angegeben. $\mathrm{u}=$ unbehandelt; $\mathrm{i}=$ inokuliert; Die Intervalle geben Standardabweichungen der gemessenen Pflanzen an. Es wurden keine signifikanten Unterschiede zwischen den Varianten gefunden (n.s.: nicht signifikant nach $\mathrm{t}-\mathrm{Test}, \mathrm{p} \leq 0,05$ ). 


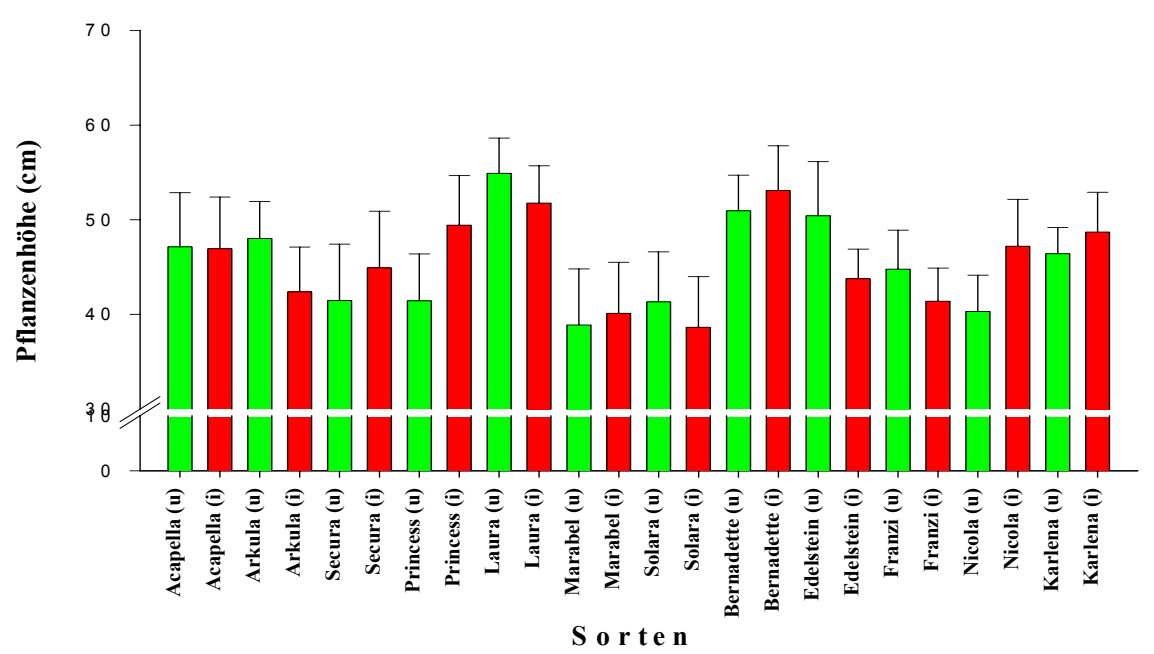

n.S.

Graphik 24: Pflanzenhöhe in den Versuchsparzellen in Kaltenberg 2003. Alle Pflanzen wurde im EC-Stadium 65 vermessen. Auf der x-Achse sind die Sorten, auf der y-Achse die Höhe der Pflanzen in $\mathrm{cm}$ angegeben. $\mathrm{u}=$ unbehandelt; $\mathrm{i}=$ inokuliert; Die Intervalle geben Standardabweichungen der gemessenen Pflanzen wieder. Es wurden keine signifikanten Unterschiede zwischen den Varianten gefunden (n.s.: nicht signifikant nach $t-T e s t, p \leq 0,05$ ).

Der Ertrag in kg/Pflanze wurde im zweiten Jahr am Standort Kaltenberg ermittelt. Dieser war stark sortenabhängig, es zeigten sich aber auch hier keine signifikanten Unterschiede zwischen inokulierter und unbehandelter Variante (Graphik 25).

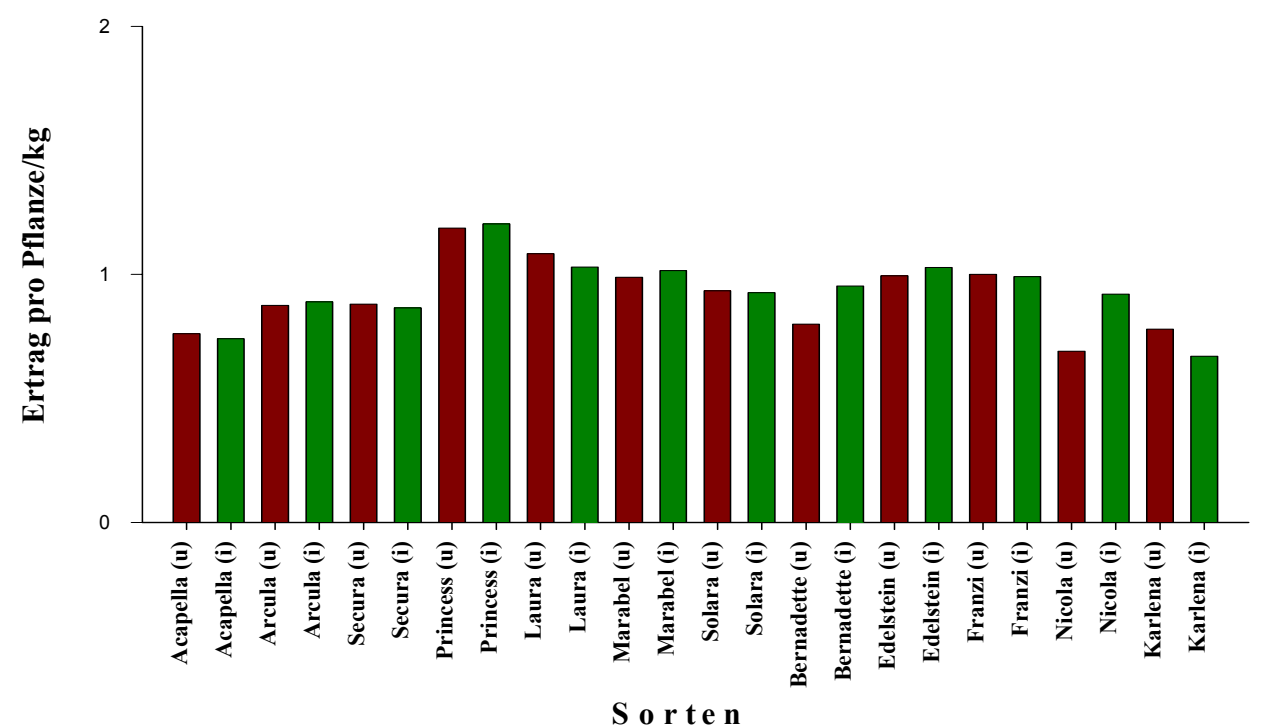

n.S.

Graphik 25: Ertrag der Sorten am Standort Kaltenberg 2003. Auf der x-Achse sind die Sorten, auf der y-Achse der Ertrag in $\mathrm{kg} /$ Pflanze angegeben. $\mathrm{u}=$ unbehandelt, $\mathrm{i}=$ inokuliert. Es konnten keine signifikanten Unterschiede zwischen inokuliert und unbehandelter Variante gefunden werden (n.s.: nicht signifikant nach $\mathrm{t}-$ Test, $\mathrm{p} \leq 0,05$ ).

Nach der Ernte zeigten alle Sorten an allen drei Standorten wiederum einen geringen Silberschorfbefall (Graphiken $26-28$ ). 


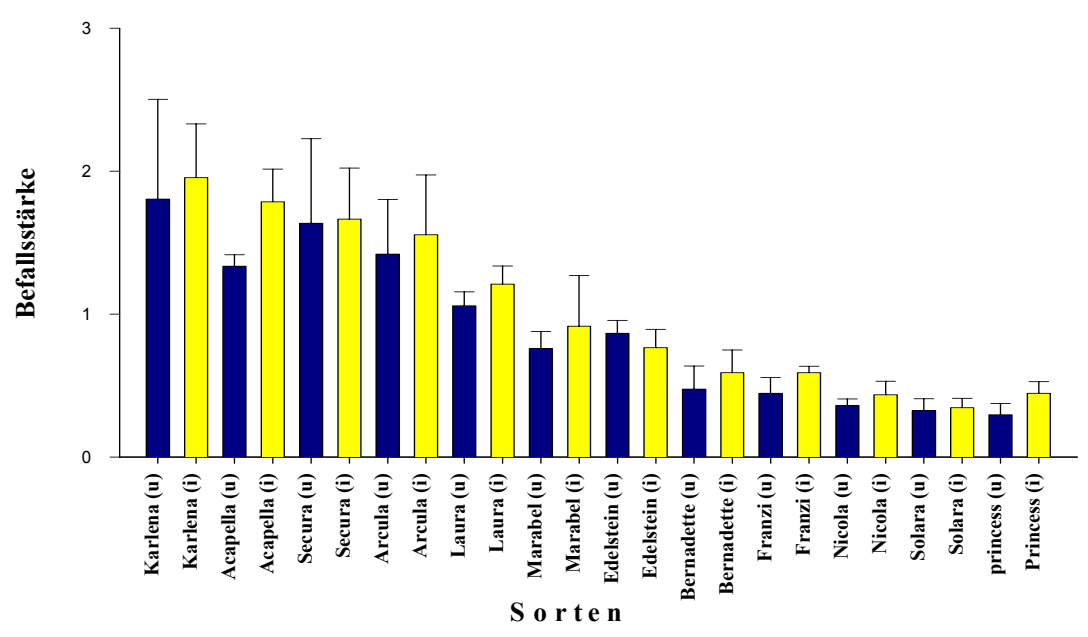

n.S.

Graphik 26: H. solani Befall der Knollen nach Ernte 2003 in Groß Lüsewitz. Auf der xAchse sind die Sorten angegeben, auf der y-Achse die Befallsstärke von 0-3 (vgl. Kapitel 6 aus Material und Methoden); $\mathrm{u}=$ unbehandelt; $\mathrm{i}=$ inokuliert. Die Intervalle geben Standardabweichungen der 50 bonitierten Knollen wieder. Es konnten keine signifikanten Unterschiede zwischen den beiden Varianten der einzelnen Sorten gefunden werden (n.s.: nicht signifikant nach $\mathrm{t}-$ Test, $\mathrm{p} \leq 0,05$ ). Alle Sorten zeigten einen unterschiedlichen Befall.

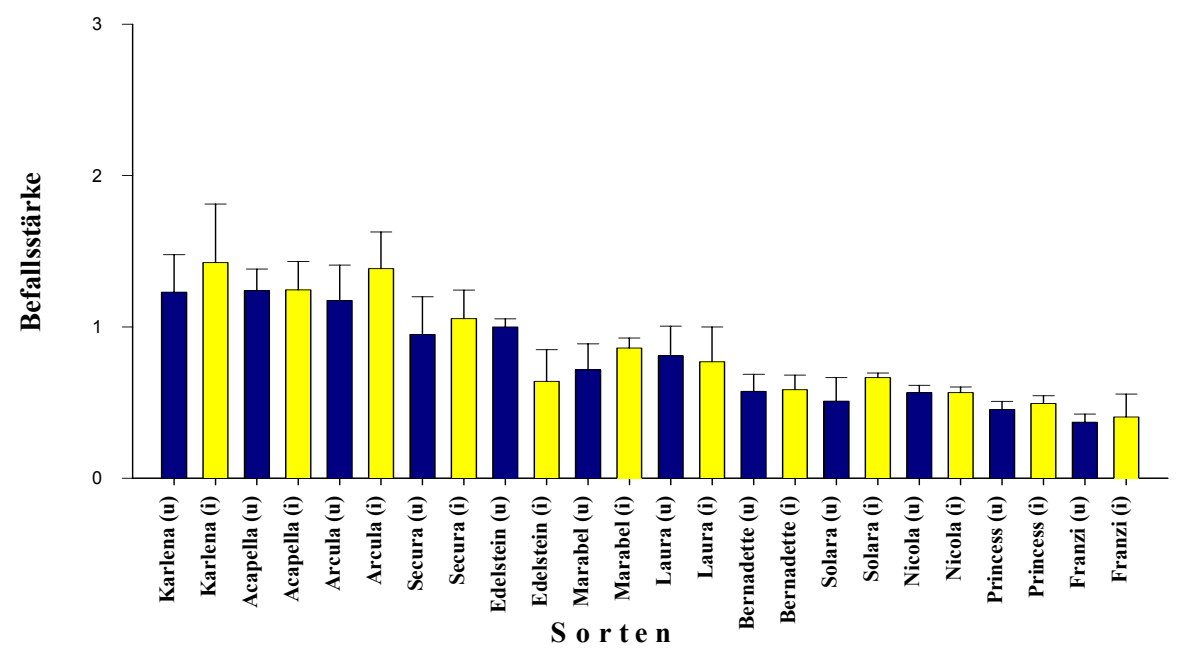

n.S.

Graphik 27: H. solani Befall der Knollen nach Ernte 2003 in Windeby. Auf der x-Achse sind die Sorten angegeben, auf der y-Achse die Befallsstärke von 0-3 (vgl. Kapitel 6 aus Material und Methoden); $\mathrm{u}=$ unbehandelt; $\mathrm{i}=$ inokuliert. Die Intervalle geben Standardabweichungen der 50 bonitierten Knollen wieder. Es konnten keine signifikanten Unterschiede zwischen den beiden Varianten der einzelnen Sorten gefunden werden (n.s.: nicht signifikant nach $\mathrm{t}-$ Test, $\mathrm{p} \leq 0,05$ ). Alle Sorten zeigten einen unterschiedlichen Befall. 


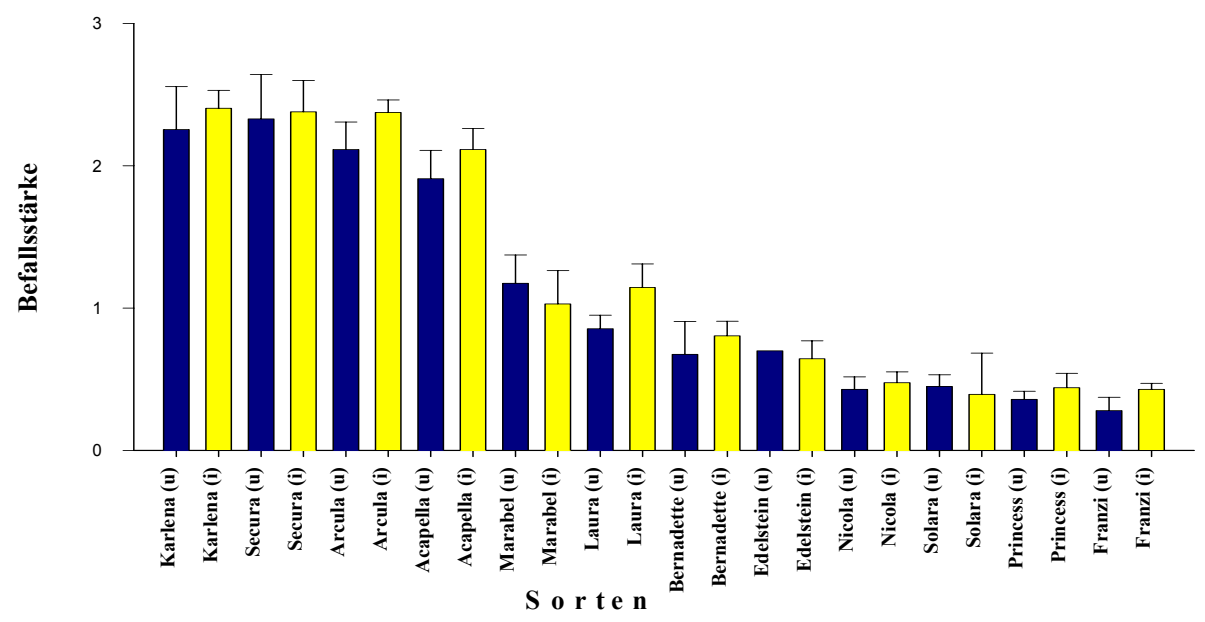

n.S.

Graphik 28: H. solani Befall der Knollen nach Ernte 2003 in Kaltenberg. Auf der x-Achse sind die Sorten angegeben, auf der y-Achse die Befallsstärke von 0-3 (vgl. Kapitel 6 aus Material und Methoden); $\mathrm{u}=$ unbehandelt; $\mathrm{i}=$ inokuliert. Die Intervalle geben Standardabweichungen der 50 bonitierten Knollen wieder. Es konnten keine signifikanten Unterschiede zwischen den beiden Varianten der einzelnen Sorten gefunden werden (n.s.: nicht signifikant nach $\mathrm{t}-\mathrm{Test}, \mathrm{p} \leq 0,05$ ). Alle Sorten zeigten einen unterschiedlichen Befall.

Dabei zeigten im zweiten Jahr die Knollen vom Standort Kaltenberg die meisten Symptome. Am Standort Rostock war der Befall wiederum am geringsten. Die Sorten Karlena, Acapella, Arcula und Secura waren auch in diesem Versuchsjahr an allen drei Standorten stark anfällig, während Princess, Franzi, und Nicola die geringste Anfälligkeit aufwiesen. Die Sorten Laura, Solara, Marabel, Bernadette, und Edelstein schwankten auch 2003 in ihrer Anfälligkeit leicht von Standort zu Standort, verblieben aber weiterhin im mittleren Anfälligkeitsbereich. Dabei konnten keine signifikanten Unterschiede zwischen den inokulierten und den unbehandelten Varianten ermittelt werden. Wie im Vorjahr war der Silberschorfbefall direkt nach der Ernte an allen drei Standorten auf Grund der Lagerausbreitung sehr gering.

Neben Silberschorf wurde genau wie im Vorjahr der Befall mit $C$. coccodes ermittelt (Graphiken $29-31)$. 


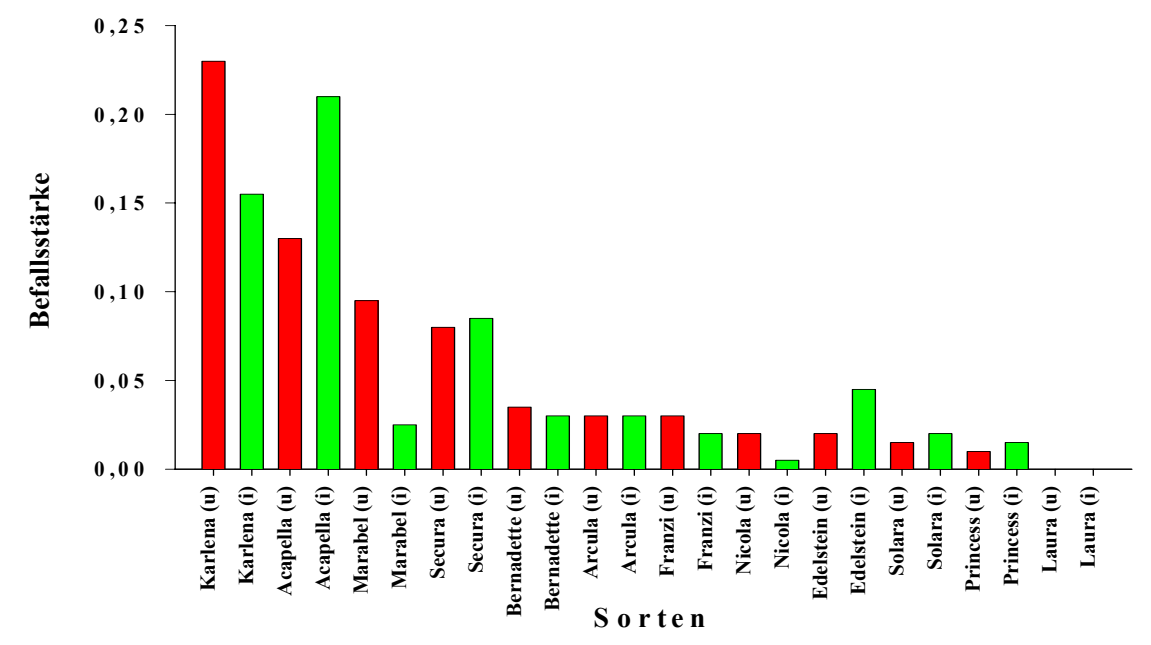

n.S.

Graphik 29: $C$. coccodes Befall der Knollen nach Ernte 2003 in Groß Lüsewitz. Auf der XAchse sind die Sorten angegeben, auf der y-Achse die Befallsstärke von 0-0,25 (vgl. Kapitel 6 aus Material und Methoden); $\mathrm{u}=$ unbehandelt; $\mathrm{i}=$ inokuliert. Es konnten keine signifikanten Unterschiede zwischen inokuliert und unbehandelter Variante gefunden werden (n.s.: nicht signifikant nach $\mathrm{t}-$ Test, $\mathrm{p} \leq 0,05$ ).

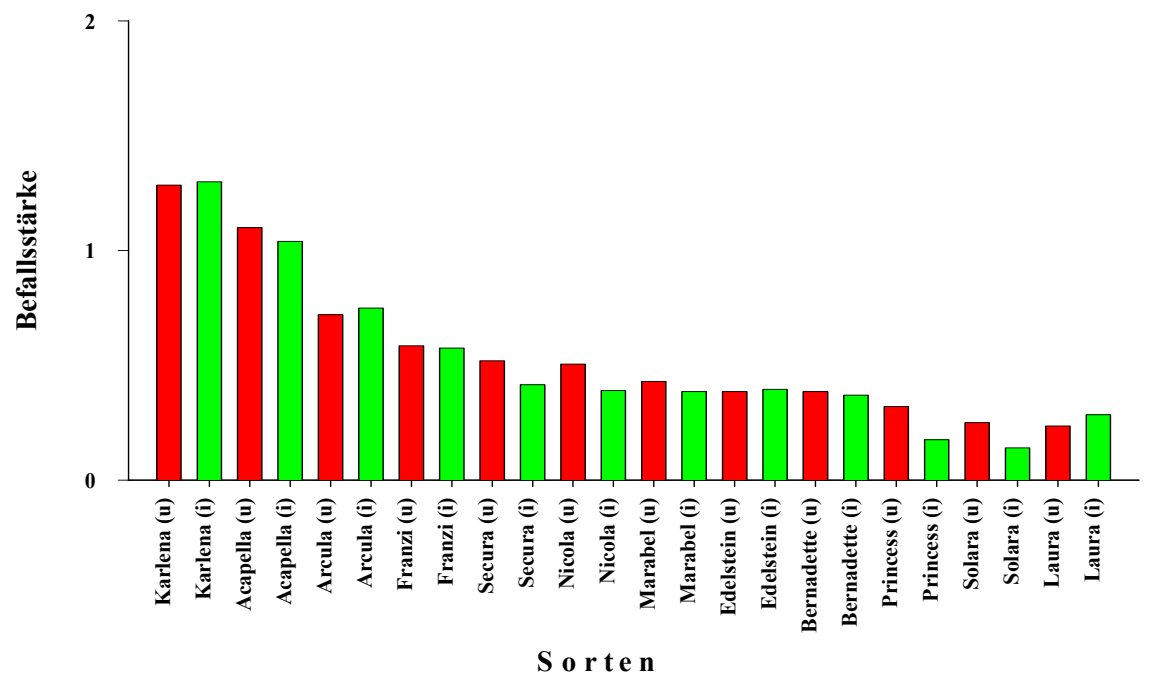

n.S.

Graphik 30: . coccodes Befall der Knollen nach Ernte 2003 in Windeby. Auf der x -Achse sind die Sorten angegeben, auf der y-Achse die Befallsstärke von 0-2 (vgl. Kapitel 6 aus Material und Methoden); $\mathrm{u}=$ unbehandelt; $\mathrm{i}=$ inokuliert. Es konnten keine signifikanten Unterschiede zwischen inokuliert und unbehandelter Variante gefunden werden (n.s.: nicht signifikant nach $\mathrm{t}-$ Test, $\mathrm{p} \leq 0,05$ ). 


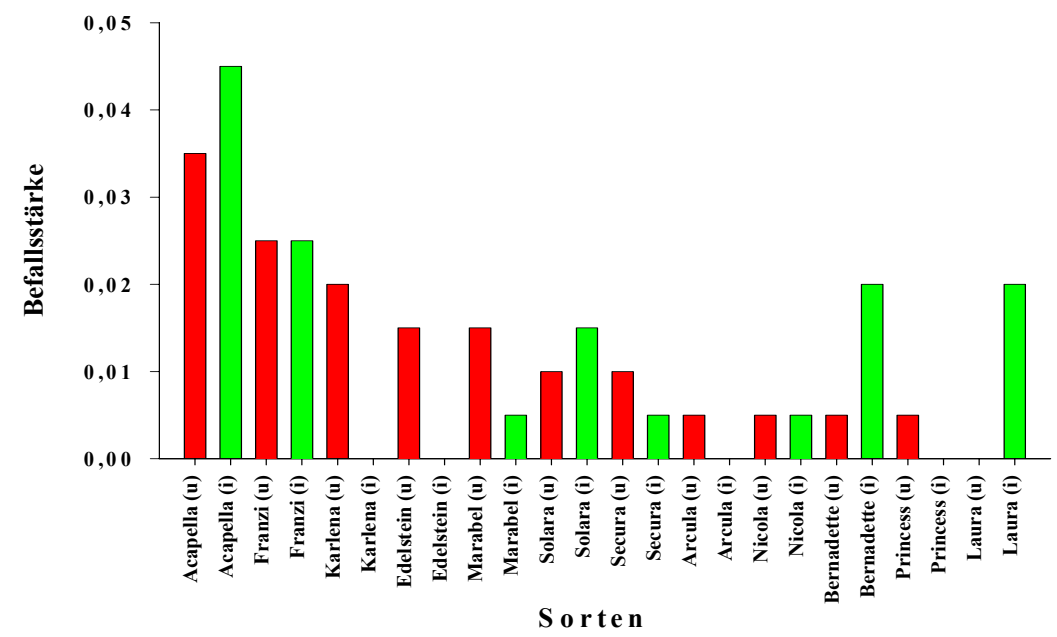

n.S.

Graphik 31: $C$. coccodes Befall der Knollen nach Ernte 2003 in Kaltenberg. Auf der xAchse sind die Sorten angegeben, auf der y-Achse die Befallsstärke von 0-0,05 (vgl. Kapitel 6 aus Material und Methoden); $\mathrm{u}=$ unbehandelt; $\mathrm{i}=$ inokuliert. Es konnten keine signifikanten Unterschiede zwischen inokuliert und unbehandelter Variante gefunden werden (n.s.: nicht signifikant nach $\mathrm{t}-$ Test, $\mathrm{p} \leq 0,05$ ).

Insgesamt war auch 2003 der Befall mit C. coccodes direkt nach der Ernte sehr gering auch im Vergleich zu Silberschorf. Die Sorten Karlena und Acapella waren immer anfällig, während die anderen Sorten von Versuchsstandort zu Versuchsstandort schwankten. Es konnte wie 2002 kein eindeutiger Zusammenhang zwischen dem Befall mit $C$. coccodes und $H$. solani ermittelt werden. Im zweiten Versuchsjahr wurde zudem die Signifikanz zwischen dem Befall mit $C$. coccodes der unbehandelten und der mit $H$. solani inokulierten Varianten errechnet. Dadurch sollte eine mögliche Konkurrenz der Pilze untereinander untersucht werden. Es konnten jedoch keine signifikanten Unterschiede zwischen der mit $H$. solani inokulierten und der unbehandelten Versuchsvarianten in Bezug auf den Befall mit $C$. coccodes festgestellt werden. Daher konnte kein Zusammenhang zwischen $H$. solani und $C$. coccodes gefunden werden. Da bis auf die Knollen aus Windeby der Befall der Knollen mit $C$. coccodes auch zwischen den Versuchsvarianten selbst stark schwankte und im Durbin-Watson-Test keine signifikanten Beziehungen bestanden, wurde auf die Erstellung von Regressionen zwischen den Standorten verzichtet.

Im zweiten Versuchsjahr wurden die Knollen aller drei Standorte ebenfalls in Boxen eingelagert (Graphiken 32 - 34). Auf Grund der Ergebnisse des Vorjahres, dass der Befallsverlauf konstant ist, wurden die eingelagerten Knollen nur einmal nach 10 Wochen bonitiert. Die Knollen des Bundessortenamts konnten aus Kapazitätsgründen in 
diesem Jahr nicht mitgeführt werden. Es wurden wiederum Signifikanzen zwischen den Varianten errechnet.

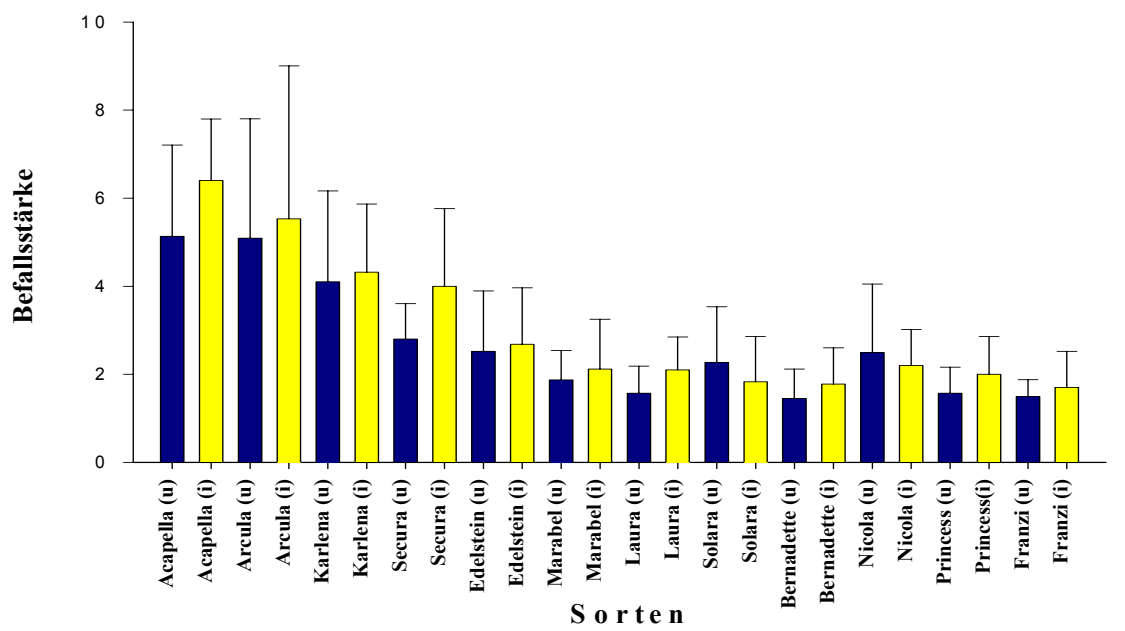

n.S.

Graphik 32: H. solani Befall der Knollen aus Groß Lüsewitz nach 10 Wochen Lagerung 2003. Die Knollen wurden im Dunkeln bei $20^{\circ} \mathrm{C}$ und $90^{\circ}$ Luftfeuchte gelagert wie beschrieben auf Silberschorf überprüft. Auf der x-Achse sind die Sorten angegeben, auf der y-Achse die Befallsstärke von 0-10 (vgl. Kapitel 6 aus Material und Methoden); $\mathrm{u}=$ unbehandelt; $\mathrm{i}=$ inokuliert. Die Intervalle geben Standardabweichungen der jeweils 25 bonitierten Knollen wieder. Es konnten keine signifikanten Unterschiede zwischen inokuliert und unbehandelter Variante der einzelnen Sorten gefunden werden (n.s.: nicht signifikant nach $t-T e s t, p \leq 0,05$ ).

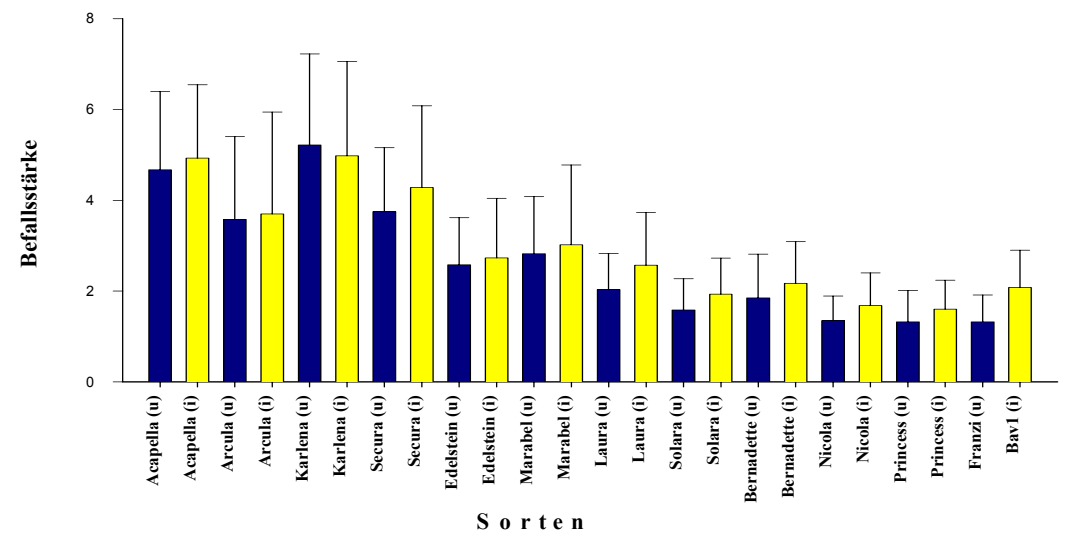

n.S.

Graphik 33: H. solani Befall der Knollen aus Windeby nach 10 Wochen Lagerung 2003. Die Knollen wurden im Dunkeln bei $20^{\circ} \mathrm{C}$ und $90^{\circ}$ Luftfeuchte gelagert und wie beschrieben auf Silberschorf überprüft. Auf der x-Achse sind die Sorten angegeben, auf der y-Achse die Befallsstärke von 0-10 (vgl. Kapitel 6 aus Material und Methoden); $\mathrm{u}=$ unbehandelt; $\mathrm{i}=$ inokuliert. Die Intervalle geben Standardabweichungen der jeweils 25 bonitierten Knollen wieder. Es konnten keine signifikanten Unterschiede zwischen inokuliert und unbehandelter Variante der einzelnen Sorten gefunden werden (n.s.: nicht signifikant nach $t-T e s t, p \leq 0,05$ ). 


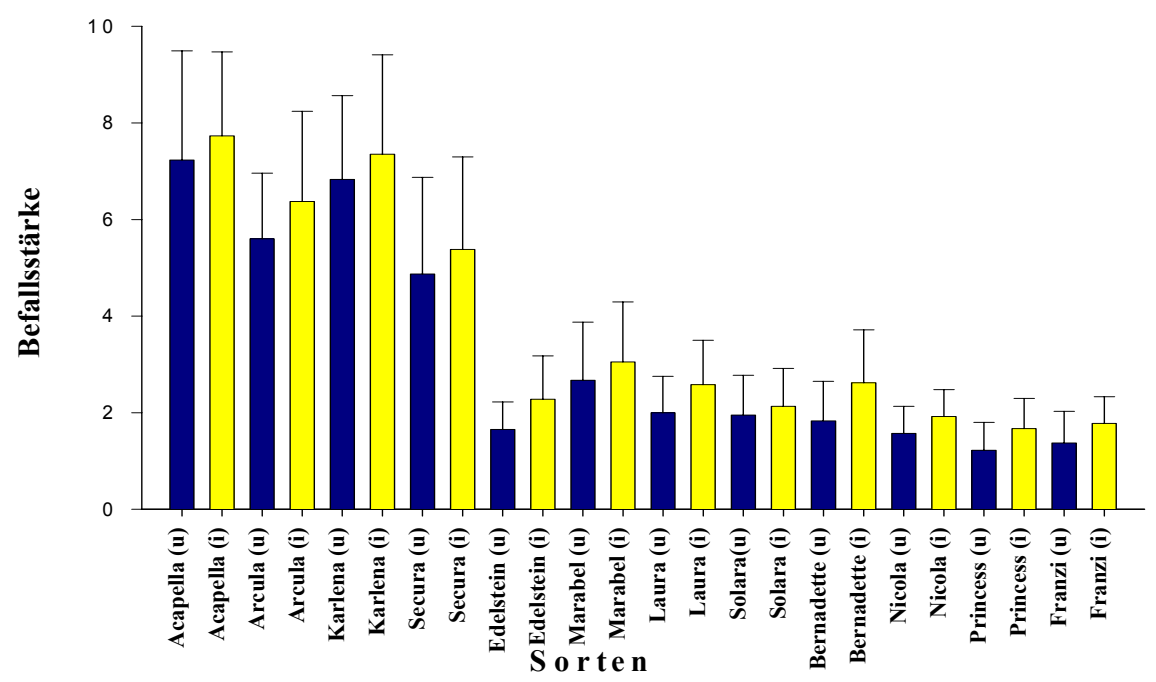

n.S.

Graphik 34: H. solani Befall der Knollen aus Kaltenberg nach 10 Wochen Lagerung 2003. Die Knollen wurden im Dunkeln bei $20^{\circ} \mathrm{C}$ und $90^{\circ}$ Luftfeuchte gelagert und wie beschrieben auf Silberschorf überprüft. Auf der x-Achse sind die Sorten angegeben, auf der y-Achse die Befallsstärke von 0-10 (vgl. Kapitel 6 aus Material und Methoden); $\mathrm{u}=$ unbehandelt; $\mathrm{i}=$ inokuliert. Die Intervalle geben Standardabweichungen der bonitierten Knollen wieder. Es konnten keine signifikanten Unterschiede zwischen inokuliert und unbehandelter Variante der einzelnen Sorten gefunden werden (n.s.: nicht signifikant nach $\mathrm{t}-$ Test, $\mathrm{p} \leq 0,05$ ).

Nach der Lagerung bei $20^{\circ} \mathrm{C}$ und $90 \%$ Luftfeuchte war die Befallsstärke bei allen Sorten an allen Standorten wiederum gestiegen. In diesem Fall war der Silberschorfbefall am Standort Kaltenberg am höchsten. Bei den als anfällig geltenden Sorten Karlena, Acapella, Arcula und Secura war bei allen drei Standorten der Anteil befallener Knollenoberfläche ebenfalls am stärksten gestiegen, bei einzelnen Knollen waren wiederum bis zu $100 \%$ der Knollenoberfläche mit Silberschorf bedeckt. Die Sorten Nicola, Princess und Franzi dagegen zeigten an allen drei Standorten wieder nur den leichten Befallsanstieg, wobei selten auf mehr als 30\% der Kartoffeloberfläche ein Befall mit $H$. solani nachgewiesen wurde. Die Sorten Laura, Marabel und Solara, Edelstein und Bernadette schwankten in ihrer Anfälligkeit wie schon in allen vorangegangenen Versuchen im mittleren Anfälligkeitsbereich. Es konnten auch bei dieser abschließenden Lagerbonitur keine signifikanten Unterschiede zwischen inokulierten und unbehandelten Varianten festgestellt werden, wobei die inokulierten Varianten in der Regel etwas höher befallen waren als die unbehandelten. Es wurden wiederum Regressionen zwischen den Feldversuchen und den Lagerversuchen errechnet (Tab. 11). 
Tabelle 11: Regressionen der Anfälligkeit der Sorten auf $\boldsymbol{H}$. solani zwischen den Feld- und Lagerversuchen 2003. Die Ergebnisse der Ernte- und Lagerergebnisse aus dem Versuchsjahr 2003 wurden miteinander in Beziehung gesetzt. Das Bestimmtheitsmaß betrug in allen Fällen 0,52 oder höher. Die Signifikanzen lagen stets bei $\mathrm{p}<0,01$. Es besteht eine signifikante Beziehung zwischen allen Parametern.

\begin{tabular}{|l|c|l|l|l|l|}
\hline & $\begin{array}{l}\text { Windeby } \\
\text { Ernte } \\
\mathbf{2 0 0 3}\end{array}$ & $\begin{array}{l}\text { Groß } \\
\text { Lüsewitz } \\
\text { Ernte 2003 }\end{array}$ & $\begin{array}{l}\text { Kaltenberg } \\
\text { Ernte 2003 }\end{array}$ & $\begin{array}{l}\text { Windeby } \\
\text { Lager 2003 }\end{array}$ & $\begin{array}{l}\text { Groß } \\
\text { Lüsewitz } \\
\text { Lager 2003 }\end{array}$ \\
\hline $\begin{array}{l}\text { Groß } \\
\text { Lüsewitz } \\
\text { Ernte 2003 }\end{array}$ & $0,86^{* * *}$ & & & & \\
\hline $\begin{array}{l}\text { Kaltenberg } \\
\text { Ernte 2003 }\end{array}$ & $0,90^{* * *}$ & $0,77^{* * *}$ & & & \\
\hline $\begin{array}{l}\text { Windeby } \\
\text { Lager 2003 }\end{array}$ & $0,84^{* * *}$ & $0,69^{* * *}$ & $0,86^{* * *}$ & & \\
\hline $\begin{array}{l}\text { Groß } \\
\text { Lüsewitz } \\
\text { Lager 2003 }\end{array}$ & $0,62^{* * *}$ & $0,52^{* * *}$ & $0,71^{* * *}$ & $0,71^{* * *}$ & \\
\hline $\begin{array}{l}\text { Kaltenberg } \\
\text { Lager 2003 }\end{array}$ & $0,81^{* * *}$ & $0,67^{* * *}$ & $0,86^{* * *}$ & $0,88^{* * *}$ & $0,77^{* * *}$ \\
\hline
\end{tabular}

Das Bestimmtheitsmaß war in allen Fällen $\geq 0,52$. Die Signifikanzen lagen immer bei $\mathrm{p}<0,01$, es besteht eine signifikante Beziehung der Anfälligkeit der Knollen zu den jeweiligen Sorten zwischen den Ergebnissen aller Versuche. Die Ergebnisse des Vorjahres konnten somit bestätigt werden. Abschließend wurden die Ergebnisse der jeweiligen Feld- und Lagerversuche der zwei Versuchsjahre zusammengefasst und ebenfalls in Regressionen verglichen (Tab. 12).

Tabelle 12: Regressionen der Anfälligkeit der Sorten auf $\boldsymbol{H}$. solani zwischen den Feld- und Lagerversuchen beider Versuchsjahre. Die Ergebnisse der Ernte- und Lagerergebnisse aus allen Versuchen wurden miteinander in Beziehung gesetzt. Das Bestimmtheitsmaß betrug in allen Fällen 0,46 oder höher. Die Signifikanzen lagen stets zwischen $p<0,01$ und $p<0,05$. Es besteht eine signifikante Beziehung zwischen allen Parametern.

\begin{tabular}{|l|l|l|l|}
\hline & Ernte 2003 & Lager 2003 & Ernte 2002 \\
\hline Lager 2003 & $0,88^{* * *}$ & & \\
\hline Ernte 2002 & $0,46^{* *}$ & $0,58^{* * *}$ & \\
\hline Lager 2002 & $0,67^{* * *}$ & $0,74^{* * *}$ & $0,81^{* * *}$ \\
\hline
\end{tabular}

Das Bestimmtheitsmaß war in allen Vergleichen $\geq 0,46$. Es wurden in allen Fällen hohe Signifikanzen zwischen $\mathrm{p}<0,01$ und $\mathrm{p}<0,05$ gefunden. Es besteht eine signifikante Beziehung zwischen der Anfälligkeit der Sorten auf H. solani aller Versuch zueinander. Somit konnte die sortenspezifische Anfälligkeit nachgewiesen werden.

Da sich die Krankheit, wie erwähnt, hauptsächlich im Lager ausbreitet und somit der Befall nach der Lagerung am höchsten ist, wurden die Ergebnisse der Lagerversuche 
beider Versuchsjahre 2002 - 03 zusammengefasst und damit ein Standardsortiment bestehend aus zwölf Kartoffelsorten zusammengestellt (Graphik 35).

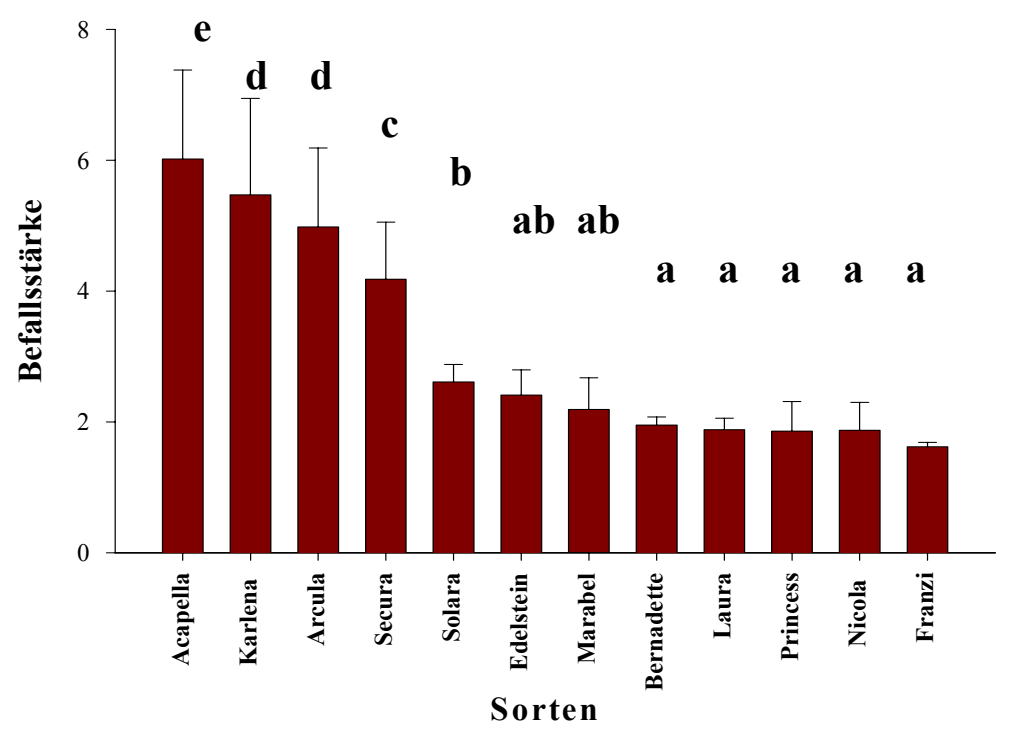

Graphik 35: Standardsortiment der zwölf untersuchten Kartoffelsorten in Bezug auf ihre H. solani Anfälligkeit. Auf der $\mathrm{x}$-Achse sind die Sorten, auf der $\mathrm{y}$-Achse die Befallsstärke von 0-8 angegeben (vgl. Kapitel 6 aus Material und Methoden). Die Intervalle geben Standardabweichungen aller bonitierten Knollen wieder. Es bestehen signifikante Unterschiede zwischen den Sorten, wobei in 5 Gruppen von statistisch gleichen Anfälligkeiten unterschoeden werden kann (a; b; c; d; e; t-Test, $\mathrm{p} \leq 0,05)$.

Nach 10 Wochen Lagerung wurden die Knollen ebenfalls auf $C$. coccodes bonitiert (Graphiken 36 - 38).

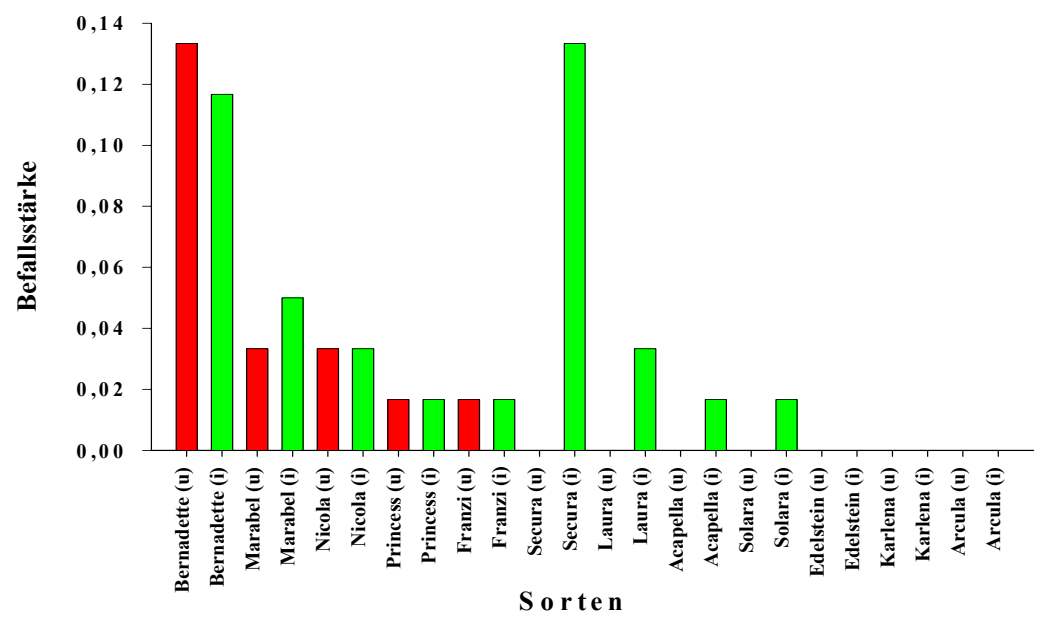

n.S.

Graphik 36: $C$. coccodes Befall nach Einlagerung der Knollen für 10 Wochen vom Standort Groß Lüsewitz 2003. Die Knollen wurden im Dunkeln bei $20^{\circ} \mathrm{C}$ und $90^{\circ}$ Luftfeuchte gelagert auf $C$. coccodes überprüft (vgl. Kapitel 6 aus Material und Methoden). Auf der x Achse sind die Sorten, auf der y-Achse die Befallsstärke von 0-0,14 dargestellt. i=inokulierte Variante $\mathrm{u}=$ Unbehandelte Variante. Es konnten keine signifikanten Unterschiede zwischen den beiden Varianten gefunden werden (n.s.: nicht signifikant nach $\mathrm{t}-$ Test, $\mathrm{p} \leq 0,05$ ). 


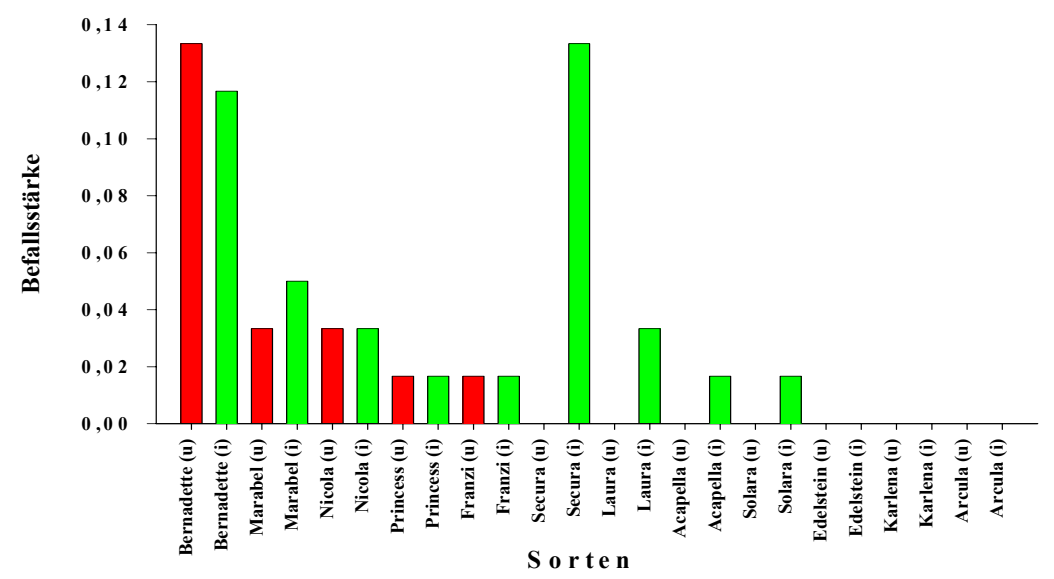

n.s.

Graphik 37: C. coccodes Befall nach Einlagerung der Knollen für 10 Wochen vom Standort Windeby 2003. Die Knollen wurden im Dunkeln bei $20^{\circ} \mathrm{C}$ und $90^{\circ}$ Luftfeuchte gelagert und wie beschrieben auf $C$. coccodes überprüft. Auf der x-Achse sind die Sorten, auf der $\mathrm{y}$-Achse die Befallsstärke von 0-0,14 (vgl. Kapitel 6 aus Material und Methoden) dargestellt. $\mathrm{i}=$ Inokulierte Variante $\mathrm{u}=$ unbehandelte Variante. Es konnten kein signifikanten Unterschiede zwischen den beiden Varianten gefunden werden (n.s.: nicht signifikant nach $\mathrm{t}-$ Test, $\mathrm{p} \leq 0,05)$.

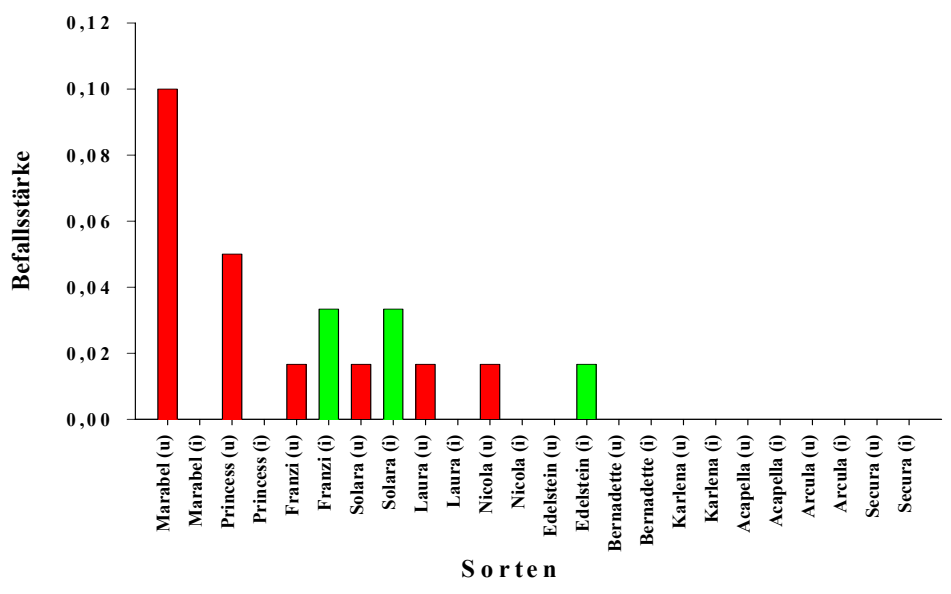

n.S.

Graphik 38: $C$. coccodes Befall nach Einlagerung der Knollen für 10 Wochen vom Standort Kaltenberg 2003. Die Knollen wurden im Dunkeln bei $20^{\circ} \mathrm{C}$ und $90^{\circ}$ Luftfeuchte gelagert und wie beschrieben auf $C$. coccodes überprüft. Auf der $\mathrm{x}-$ Achse sind die Sorten, auf der $\mathrm{y}$-Achse die Befallsstärke von 0-0,12 (vgl. Kapitel 6 aus Material und Methoden) dargestellt. $\mathrm{i}=$ inokulierte Variante $\mathrm{u}=$ unbehandelte Variante. Es konnten kein signifikanten Unterschiede zwischen den beiden Varianten gefunden werden (n.s.: nicht signifikant nach $\mathrm{t}-$ Test, $\mathrm{p} \leq 0,05)$.

Insgesamt war der Befall auch nach der Lagerung bei allen drei Versuchsvarianten sehr gering, wesentlich geringer als der Befall mit Silberschorf. Die Knollen des Feldversuches Windeby wiesen die stärksten Symptome auf. Nach der Lagerung schwankten die Sorten wie in allen Vorversuchen in ihrem Befall von Versuch zu 
Versuch. Dabei konnte keine Sorte als besonders anfällig erkannt werden. Es konnten Unterschiede im Befall der Knollen mit C. coccodes zwischen den mit Silberschorf inokulierten und den unbehandelten Varianten gefunden werden. Diese schwankten jedoch von Parzelle zu Parzelle und standen in keinem Zusammenhang mit der Inokulation mit $H$. solani. Es wurden Signifikanzen zwischen den beiden Varianten errechnet, dabei konnten keine signifikanten Unterschiede gefunden werden. Da der Befall der Knollen auch zwischen den Versuchsvarianten selbst stark schwankte und im Durbin-Watson-Test keine signifikanten Beziehungen bestanden, wurde auch hier auf die Erstellung von Regressionen zwischen den Standorten verzichtet. Insgesamt konnte somit kein Zusammenhang zwischen der Befallsstärke mit $H$. solani und dem mit $C$. coccodes gefunden werden.

\section{Nachstellung der Feldversuche im Gewächshaus}

Die Feldversuche wurden im Gewächshaus nachgestellt, um äußere Faktoren wie Wetter, Bodenverhältnisse und Klima auszuschließen. Zunächst wurde der Vorbefall der Pflanzknollen, die vom Bundessortenamt zur Verfügung gestellt wurden, ermittelt. Es wurde festgestellt, dass alle Sorten Befall aufwiesen (Graphik 39). Keine Sorte erreichte jedoch eine Boniturnote über 2,5 (entspricht 25\% befallene Oberfläche), was bedeutet, dass der anfängliche Befallsdruck der unbehandelten Pflanzknollen sehr gering war. Durch Inokulation der Hälfte des Versuchs war somit ein Vergleich zwischen hohem und niedrigem Befallsdruck möglich.

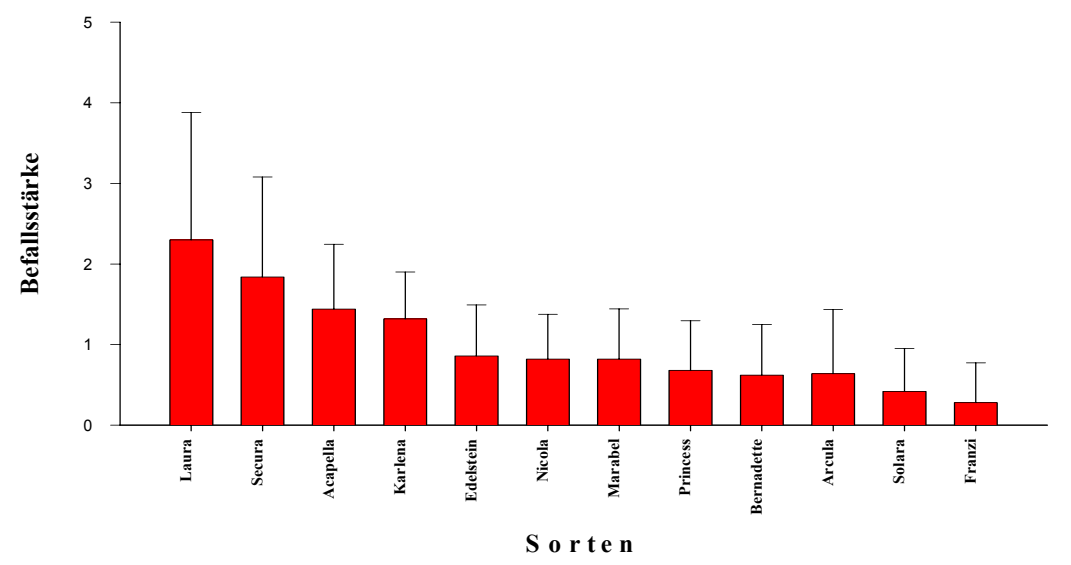

Graphik 39: Vorbefall der Sorten des Bundessortenamts mit $H$. solani im Gewächshausversuch. Auf der x-Achse sind die Sorten dargestellt, auf der y-Achse die Befallsstärke von 0-5 (vgl. Kapitel 6 aus Material und Methoden). Die Intervalle geben Standardabweichungen der 50 bonitierten Knollen wieder. Alle Sorten zeigten einen Befall. 
Der Auflauf der Pflanzen war sortenabhängig zeitlich versetzt. Vier Wochen nach dem Pflanzen der Knollen waren im Gewächshaus 100 \% aller Pflanzen aufgelaufen (Abb. 8). In ihrem Aufgang konnten keinerlei Unterschiede zwischen inokulierten und unbehandelten Knollen erkannt werden.

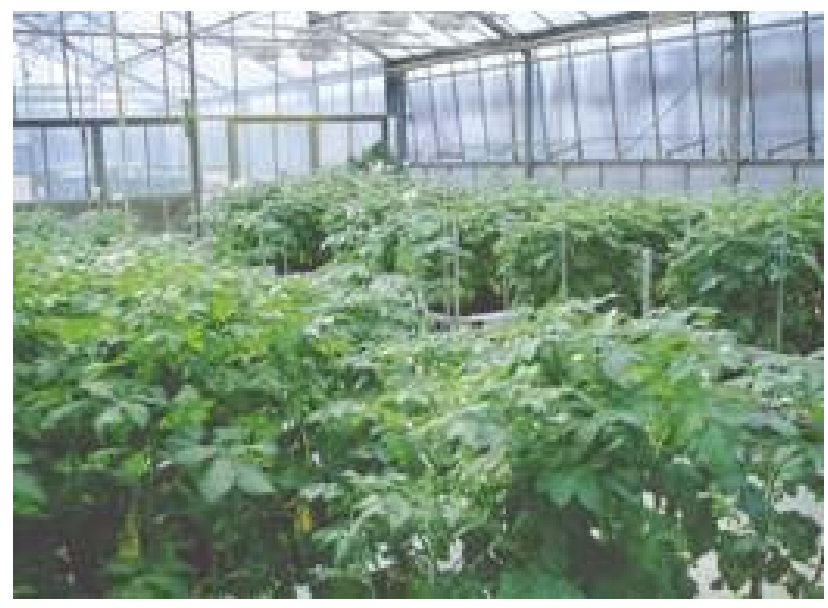

Abbildung 8: Aufgang der Sorten im Gewächshaus. $100 \%$ aller Knollen liefen auf, wobei kein Unterschied zwischen inokulierter und unbehandelter Variante bestand.

Nach der Ernte wurde zunächst der Ertrag pro Pflanze in kg ermittelt (Graphik 40). Der Ertrag im Gewächshaus schwankte ebenfalls stark sortenabhängig, es konnte jedoch kein signifikanter Unterschied zwischen dem Ertrag der unbehandelten Pflanzknollen zu dem der inokulierten Knollen festgestellt werden.

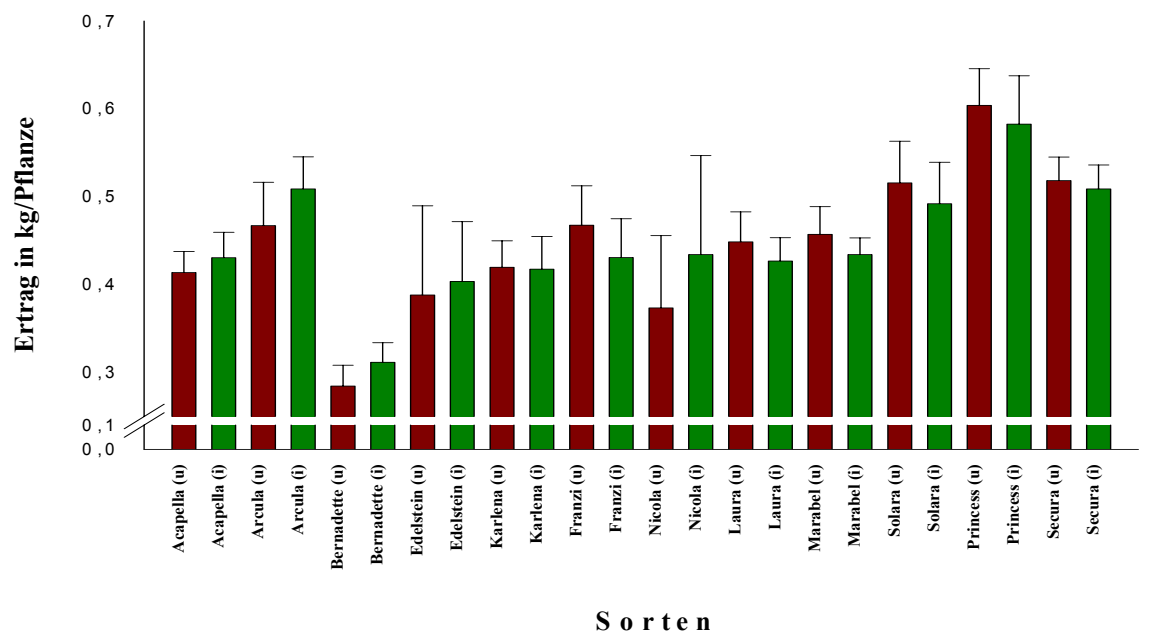

n.S.

Graphik 40: Ertrag pro Pflanze im Gewächshaus. Auf der x-Achse sind die Sorten dargestellt, auf der y-Achse der Ertrag in $\mathrm{kg} /$ Pflanze. $\mathrm{i}=$ Inokulierte Variante $\mathrm{u}=$ Unbehandelte Variante. Die Intervalle geben Standardabweichungen gewogener Knollen/Topf wieder. Es konnten keine signifikanten Unterschiede zwischen der inokulierten und den unbehandelten Varianten gefunden werden (n.s.: nicht signifikant nach $\mathrm{t}-\mathrm{Test}, \mathrm{p} \leq 0,05$ ). 
Bei der Bonitur des Silberschorfbefalls nach der Ernte zeigten alle Knollen Befall mit Silberschorf (Graphik 41).

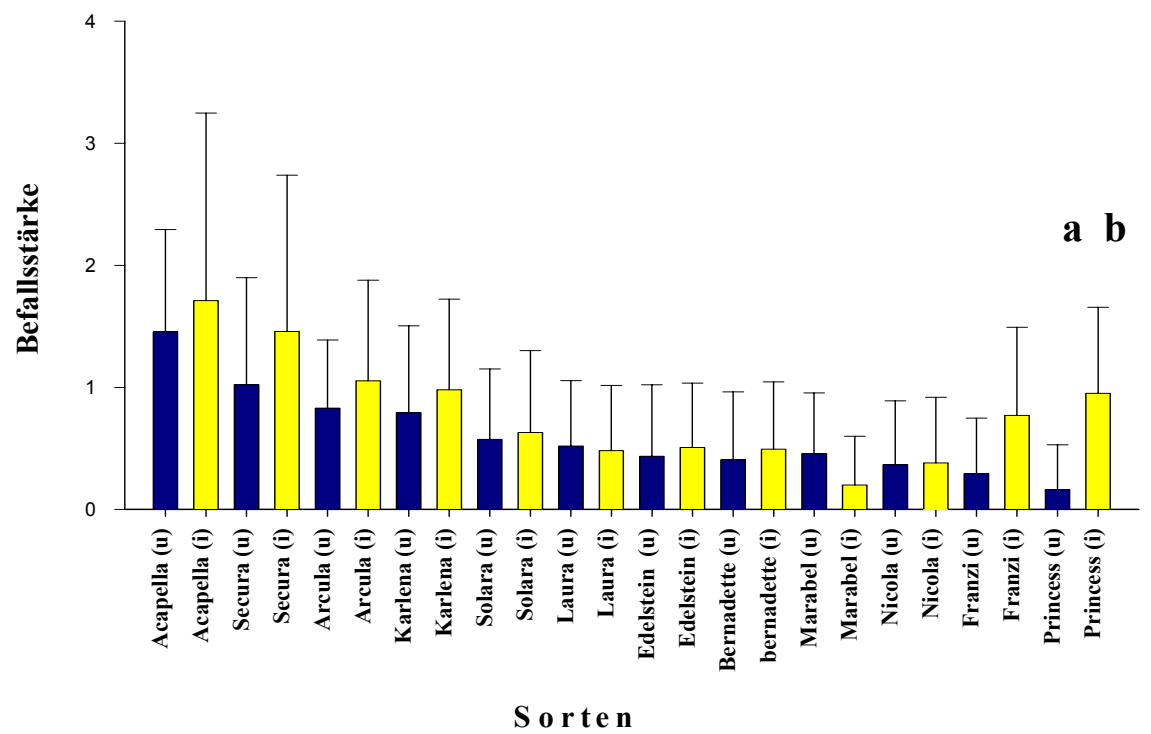

n.S.

Graphik 41: H. solani Befall der Knollen nach Ernte im Gewächshaus. Auf der x-Achse sind die Sorten angegeben, auf der y-Achse die Befallsstärke von 0-4 (vgl. Kapitel 6 aus Material und Methoden). $\mathrm{u}=$ unbehandelt; $\mathrm{i}=$ inokuliert. Die Intervalle geben Standardabweichungen der bonitierten Knollen wieder. Insgesamt konnten keine signifikanten Unterschiede zwischen inokuliert und unbehandelter Variante gefunden werden (n.s.: nicht signifikant nach $\mathrm{t}-$ Test, $\mathrm{p} \leq 0,05)$. Beim Vergleich der Varianten der einzelnen Sorten zeigte sich nur ein signifikanter Unterschied zwischen den Varianten der Sorte Princess (a bzw. b).

Dabei konnten keine signifikanten Unterschiede zwischen den Knollen von vorher inokulierten und unbehandelten Varianten festgestellt werden. Alle Sorten zeigten eine sehr ähnliche Anfälligkeit wie schon im Jahr zuvor im Feld und Lager. Vor allem die stark anfälligen und wenig anfälligen Sorten zeigten auch im Gewächshaus die gleiche Anfälligkeit wie im Feld. Die Sorten Acapella, Arcula, Secura und Karlena waren wie in allen vorangegangenen Versuchen stark anfällig, Nicola, Franzi und Princess dagegen zeigten wie schon zuvor nur sehr wenige Symptome. Die Sorten Marabel, Solara, Laura, Bernadette und Edelstein lagen wiederum im Mittelfeld. Neben Silberschorf wurde auch im Gewächshaus der Befall mit C. coccodes bonitiert (Graphik 42). Insgesamt war der Befall sehr gering. Der Befall schwankte zwischen den Versuchsvarianten, es konnte jedoch kein signifikanter Unterschied zwischen den mit Silberschorf inokulierten und den unbehandelten Varianten festgestellt werden. Es scheint also kein Zusammenhang zwischen Silberschorf - Befallsdruck und C. coccodes Befall zu bestehen. 


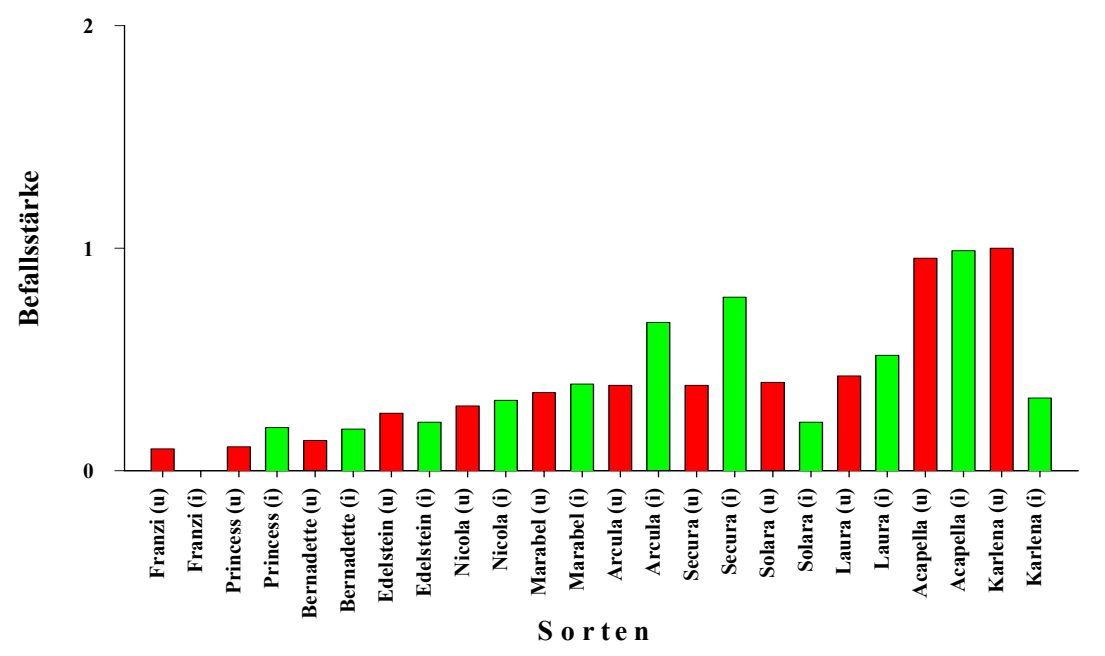

n.S.

Graphik 42: $\boldsymbol{C}$. coccodes Befall nach Ernte im Gewächshaus. Auf der x-Achse sind die Sorten, auf der y-Achse die Befallsstärke von 0-2 dargestellt (vgl. Kapitel 6 aus Material und Methoden). Es konnten kein signifikanten Unterschiede zwischen der mit Silberschorf inokulierten und der unbehandelten Variante gefunden werden (n.s.: nicht signifikant nach $\mathrm{t}-$ Test, $\mathrm{p} \leq 0,05$, Durbin - Watson - Test: $\mathrm{p}>0,10$ ).

Da sich Silberschorf im Lager ausbreitet, wurden die Knollen ebenfalls eingelagert und nach 10 Wochen erneut auf $H$. solani überprüft (Graphik 43).

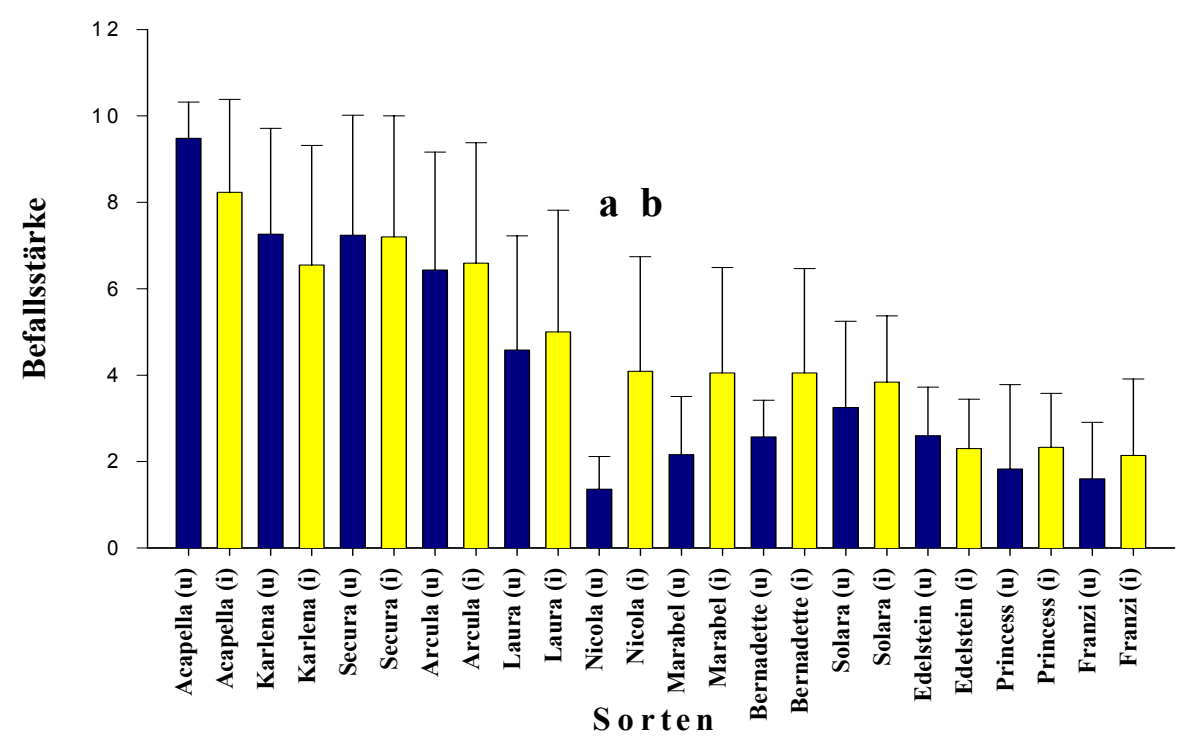

n.S.

Graphik 43: H. solani Befall der Knollen aus dem Gewächshaus nach 10 Wochen Lagerung. Auf der $\mathrm{x}$-Achse sind die Sorten angegeben, auf der $\mathrm{y}$-Achse die Befallsstärke von 0-12 (vgl. Kapitel 6 aus Material und Methoden). $\mathrm{u}=$ unbehandelt; $\mathrm{i}=$ inokuliert. Die Intervalle geben Standardabweichungen der bonitierten Knollen wieder. Es konnten keine signifikanten Unterschiede zwischen inokuliert und unbehandelter Variante gefunden werden (n.s.: nicht signifikant nach $\mathrm{t}-$ Test, $\mathrm{p} \leq 0,05)$. Beim Vergleich der Varianten der einzelnen Sorten zeigte sich im t-Test nur ein signifikanter Unterschied zwischen den Varianten der Sorte Nicola (a bzw. b). Die Knollen wurden im Dunkeln bei $20^{\circ} \mathrm{C}$ und $90^{\circ}$ Luftfeuchte gelagert und wie beschrieben auf Silberschorf überprüft. 
Nach der Lagerung der Knollen war der Prozentsatz der befallenen Oberfläche bei allen Sorten deutlich gestiegen. Dabei war der Anstieg bei den als anfällig eingestuften Sorten Acapella, Arcula, Karlena und Secura wesentlich stärker, während die als weniger anfällig geltenden Sorten Nicola, Franzi und Princess auch nach der Lagerung nur geringe Silberschorfsymptome aufwiesen. Es konnten auch im Gewächshaus keine statistisch signifikanten Unterschiede zwischen dem $H$. solani Befall bei inokulierten und unbehandelten Varianten festgestellt werden.

Es wurden Regressionen zwischen dem Ernte- und Lagerversuch sowie mit den Feldund Lagerversuchen errechnet (Tabelle 13).

Tabelle 13: Regressionen der Anfälligkeit der Sorten auf $\boldsymbol{H}$. solani zwischen den Feld- und Lagerversuchen beider Versuchsjahre sowie den Gewächshausversuchen. Die Ergebnisse der Ernte- und Lagerergebnisse aus dem Gewächshaus wurden miteinander in Beziehung gesetzt. Das Bestimmtheitsmaß betrug in allen Fällen 0,40 oder höher. Die Signifikanzen lagen stets zwischen $\mathrm{p}<0,01$ und $\mathrm{p}<0,05$. Es besteht eine signifikante Beziehung zwischen allen Parametern.

\begin{tabular}{|l|l|l|l|l|l|}
\hline & $\begin{array}{l}\text { Ernte } \\
\mathbf{2 0 0 3}\end{array}$ & $\begin{array}{l}\text { Lager } \\
\mathbf{2 0 0 3}\end{array}$ & $\begin{array}{l}\text { Ernte } \\
\mathbf{2 0 0 2}\end{array}$ & $\begin{array}{l}\text { Lager } \\
\mathbf{2 0 0 2}\end{array}$ & $\begin{array}{l}\text { Gewächshaus } \\
\text { Ernte }\end{array}$ \\
\hline $\begin{array}{l}\text { Gewächshaus } \\
\text { Ernte }\end{array}$ & $0,58^{* * *}$ & $0,71 * * *$ & $0,40^{* *}$ & $0,42^{* *}$ & \\
\hline $\begin{array}{l}\text { Gewächshaus } \\
\text { Lager }\end{array}$ & $0,84^{* * *}$ & $0,84 * * *$ & $0,52 * * *$ & $0,52 * * *$ & $0,81 * * *$ \\
\hline
\end{tabular}

Das Bestimmtheitsmaß war in allen Berechnungen $\geq 0,40$. Die Signifikanzen lagen auch beim Vergleich zwischen Gewächshaus- und Feld- und Lagerversuchen stets zwischen $\mathrm{p}<0,01$ und $\mathrm{p}<0,05$. Eine signifikante Beziehung zwischen der Anfälligkeit der Knollen und den entsprechenden Sorten konnte auch im Gewächshaus bestätigt werden. Das nach den Feld- und Lagerversuchen errechnete Standardsortiment wurde somit im Gewächshaus bestätigt.

Auch nach der Einlagerung wurden die Knollen auf C. coccodes überprüft (Graphik 44). Der Befall war insgesamt sehr gering, es waren nie mehr als 2,5\% der Knollenoberfläche befallen. Auf den meisten Knollen konnten keine C. coccodes Symptome mehr nachgewiesen werden. Ein signifikanter Unterschied zwischen inokulierter und unbehandelter Variante bestand nicht, da der $\mathrm{t}-$ Test $\mathrm{p} \leq 0,05$ ergab. Da der Befall der Knollen auch zwischen den Versuchsvarianten selbst stark schwankte und im Durbin-Watson-Test keine signifikanten Beziehungen bestanden, wurde auch hier 
auf die Erstellung von Regressionen zwischen den Ernte- und Lagerversuchen im Gewächshaus und Feld verzichtet. Somit scheint auch im Gewächshaus bestätigt zu werden, dass kein Zusammenhang zwischen der H. solani Befallsstärke und dem Befall mit C. coccodes besteht.

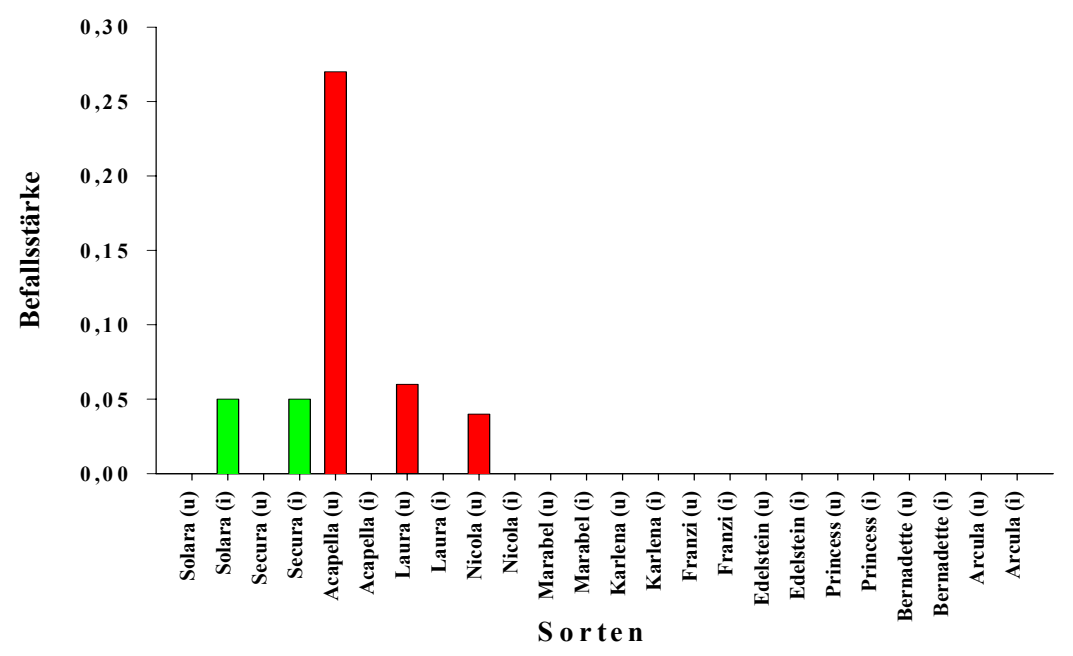

n.S.

Graphik 44: $C$. coccodes Befall der Knollen nach Lagerung für 10 Wochen aus dem Gewächshaus. Auf der x-Achse sind die Sorten, auf der y-Achse die Befallsstärke von 0-0,3 angegeben. $\mathrm{u}=$ unbehandelt; $\mathrm{i}=$ inokuliert. Es konnten kein signifikanten Unterschiede zwischen der inokulierten und der unbehandelten Variante gefunden werden (n.s.: nicht signifikant nach $\mathrm{t}-$ Test, $\mathrm{p} \leq 0,05)$. Die Knollen wurden im Dunkeln bei $20^{\circ} \mathrm{C}$ und $90^{\circ}$ Luftfeuchte gelagert wie beschrieben auf $C$. coccodes überprüft. 


\section{Untersuchung der Resistenzfaktoren}

\subsection{Strukturelle Abwehrmechanismen}

\subsubsection{Periderm-Cortexdicke}

Bei der Vermessung der Periderm-Cortex-Dicke der verschiedenen Kartoffelsorten konnten anhand der computer-basierten Technik genaue Daten gewonnen werden. Nach der Mittelwertbildung von insgesamt ca. 600 - 700 Datenpunkten pro Sorte ergab sich das in Graphik 49 aufgezeigte Spektrum.

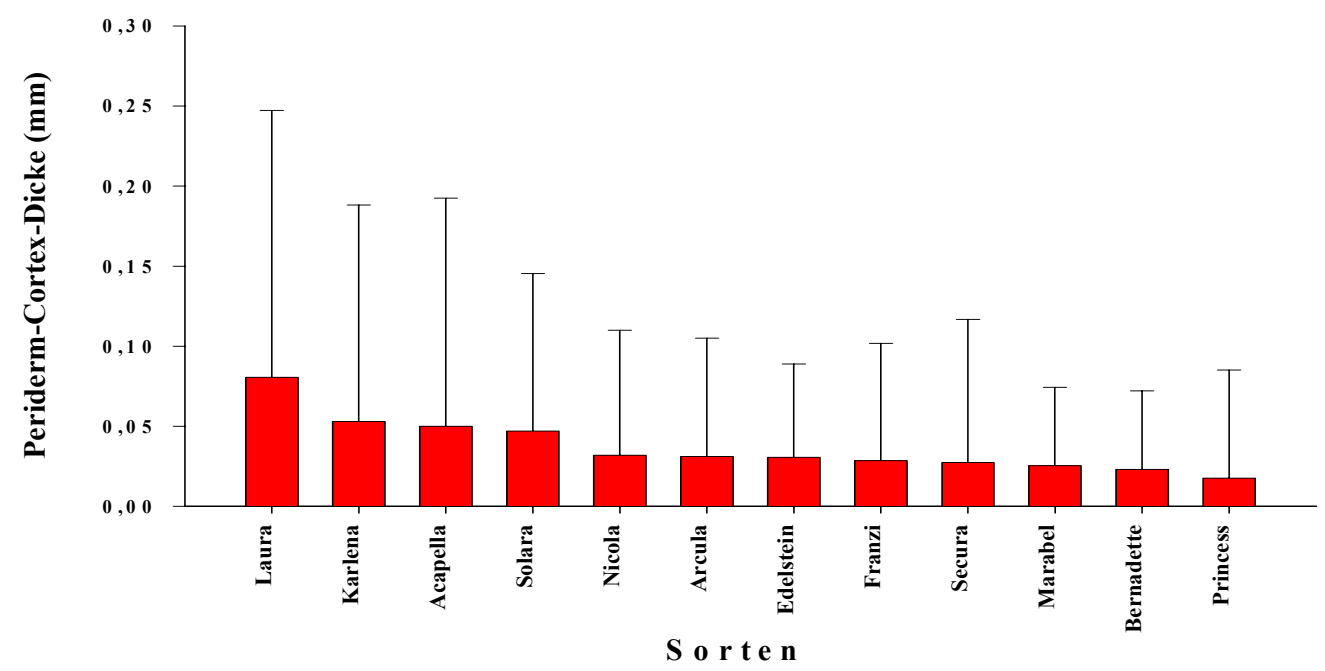

Graphik 49: Schalendicke der verschiedenen Kartoffelsorten. Auf der x-Achse sind die Sorten dargestellt, auf der $\mathrm{y}$-Achse die Periderm-Cortex-Dicke in $\mathrm{mm}$. Die Intervalle bezeichnen die Standardabweichungen der jeweiligen ca. 600-700 Datenpunkte. Pro Sorte wurden jeweils 10 Dünnscchnitte von je 5 Knollen gemessen.

Die Sorten Laura, Karlena und Acapella verfügen demnach über eine dicke PeridermCortexschicht, während Marabel, Bernadette und Princess nur dünne Schichten verkorkter Zellen aufweisen. Dabei wurde darauf geachtet, dass die vermessenen Knollen im gleichen physiologischen Alter und Zustand waren. Aufgrund der unterschiedlichen Peridermstruktur waren die Standardabweichungen bei allen Sorten sehr hoch. Anschließend wurde eine Regression zwischen den im Feld, Lager und Labor ermittelten Anfälligkeiten und der Periderm-Cortex-Dicke errechnet (Graphik $50)$. 


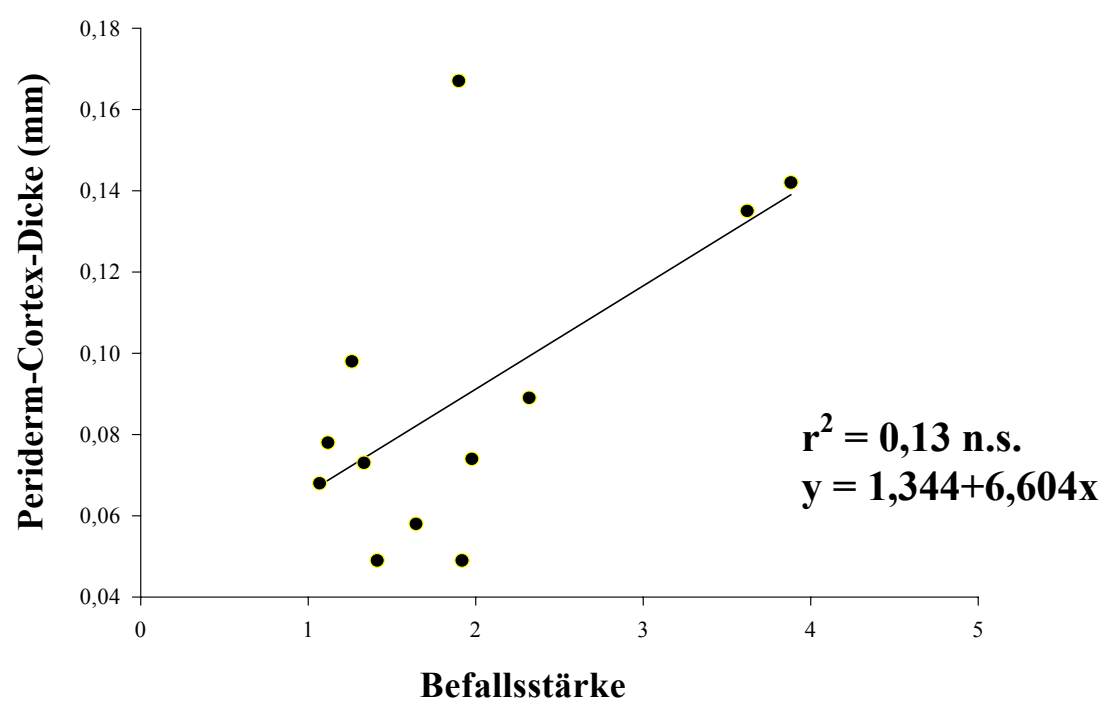

Graphik 50: Regression nach dem Durbin-Watson-Test zwischen Befallsstärke und Periderm-Cortex-Dicke der verschiedenen Sorten. Auf der x-Ache ist die Befallsstärke aus den Feld-, Lager- und Gewächshausproben dargestellt, auf der y-Achse die PeridermCortexdicke in mm der 600-700 Datenpunkte je Sorte. Der Regressionskoeffizient beträgt 0,13, die Signifikanz liegt im Durbin-Watson-Test bei $\mathrm{p}<0,10$ (n.s.). Es besteht keine signifikante Beziehung zwischen den Parametern.

Der Regressionskoeffizient beträgt 0,37, was zeigt, dass wahrscheinlich keine direkte Abhängigkeit zwischen Anfälligkeit und Periderm-Cortex-Dicke der verschiedenen Kartoffelsorten besteht. Außerdem konnte im Durbin-Watson-Test keine statistisch signifikante Beziehung zwischen den beiden Parametern errechnet werden.

Die technische Umsetzung einer Silberschorfbonitur mittels Bildanalyse stellte sich als äußerst schwierig heraus, da zunächst jede einzelne Knollenoberfläche aus dem dreidimensionalen Raum auf eine zweidimensionale Fläche gerechnet werden muss. Zum anderen erzeugt nicht nur Silberschorf braune bis silbergraue Flecken auf der Knollenoberfläche, sondern eine Vielzahl an weiteren Faktoren wie z.B. andere Pathogene, Verletzungen, fehlende Schalenfestigkeit u.s.w. Dabei erzeugt jede Sorte Silberschorfsymptome, die sich in ihrer Farbgebung von Symptomen an anderen Sorten stark unterscheiden können. Dieses Bildbearbeitungssystem stellt jedoch wesentlich höhere Ansprüche an Kamera und Software und konnte im Rahmen dieser Arbeit daher nicht realisiert werden. 


\subsubsection{Schalenbeschaffenheit}

Die Knollen wurden gereinigt und vor und nach einem Wasser- und Staubbad gewogen (Abb. 9) und anschließend die Differenz errechnet. Daraus wurde auf die Oberflächenstruktur der jeweiligen Sorten geschlossen.
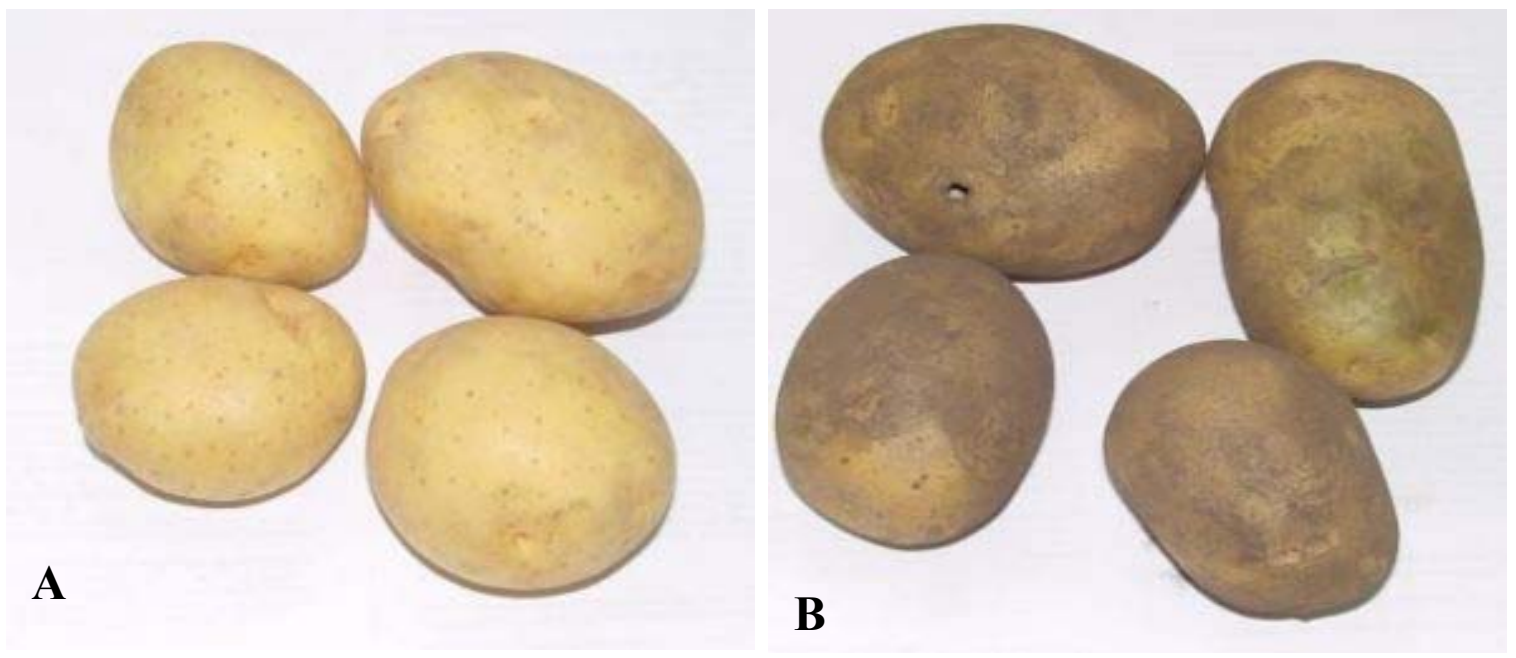

Abbildung 9: Oberflächenbeschaffenheit von Kartoffelknollen. Die Knollen wurden gewaschen und vor (A) und nach (B) einem Staubbad gewogen. Anschließend wurde die Differenz des Gewichts errechnet und so auf indirekt auf die Schalenbeschaffenheit zurückgeschlossen (Menge anhaftender Erde).

Es wurden alle zwölf im Feld untersuchten Sorten getestet, es ergab sich das in Graphik 51 dargestellte Spektrum.

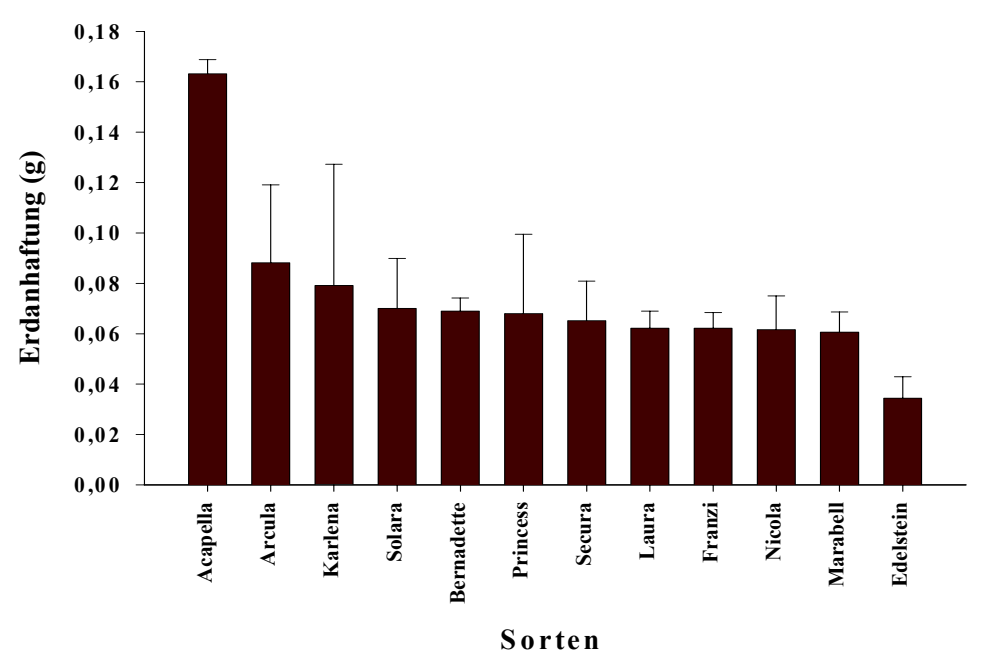

Graphik 51: Erdanhaftung an den Knollen der verschiedenen Sorten. Auf der x-Achse sind die Sorten, auf der y-Achse die Erdanhaftung in g dargestellt. Die Intervalle geben die Standardabweichungen der 20 gemessenen Knollen dar. 
Es wurde eine Regression zwischen dem Sortenspektrum und der Erdanhaftung errechnet, um eine Beziehung zwischen Schalenstruktur und Anfälligkeit zu untersuchen (Graphik 52). Der Regressionskoeffizient ergab 0,33, während im DurbinWatson-Test keine signifikante Beziehung zwischen den beiden Parametern gefunden werden konnte. Daher scheint auch die Menge der angehafteten Erde und die darauf bezogene Schalenstruktur keine besondere Rolle als Resistenzfaktor gegen H. solani zu spielen.

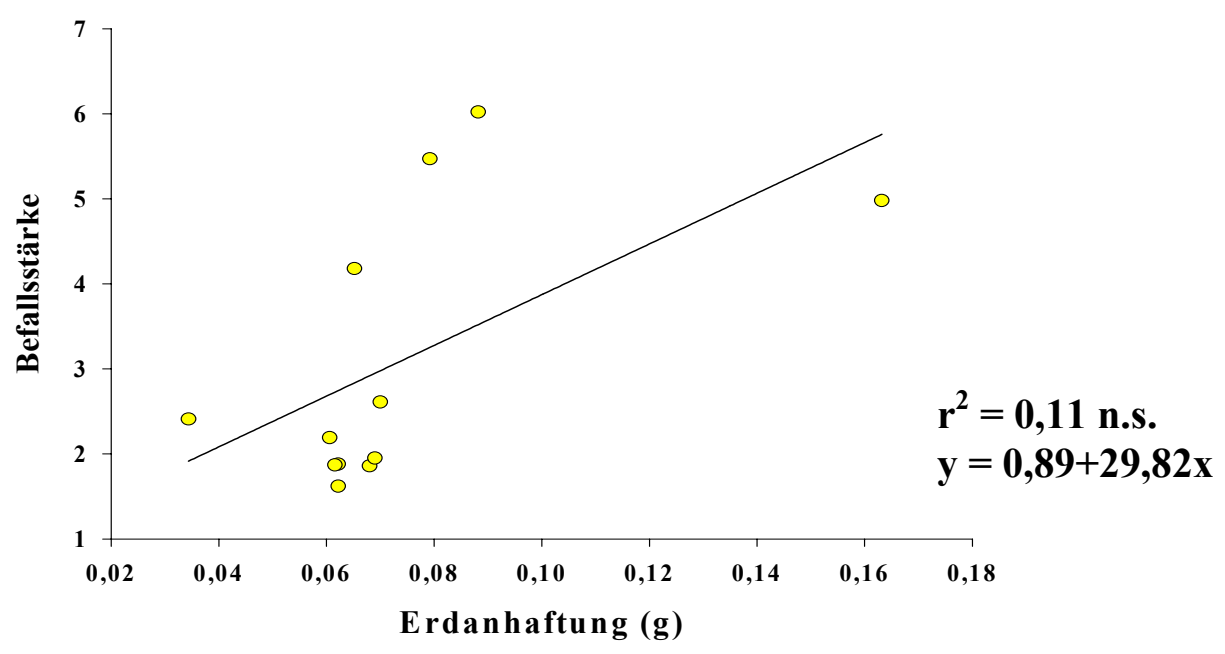

Graphik 52: Regression zwischen der Befallsstärke der zwölf Sorten und der Erdanhaftung. Auf der x-Achse ist die Erdanhaftung in g, auf der y-Achse die Befallsstärke von 1-7 angegeben (vgl. Kapitel 6 aus Material und Methoden). Der Regressionskoeffizient liegt bei 0,11 , im Durbin-Watson-Test konnte keine signifikante Beziehung zwischen den beiden Parametern gefunden werden (n.s.: nicht signifikant; $p<0,10$ ).

\subsubsection{Mikroskopische Untersuchungen}

Die mikroskopischen Untersuchungen wurden durchgeführt, um zu überprüfen, wie und wie tief $H$. solani in das Gewebe der Knolle eindringen kann und ob die Schalenstruktur hierbei eine Rolle spielt. Dafür wurde der Pilz in Kartoffelproben mit verschiedenen Färbemethoden angefärbt und anschließend unter dem Mikroskop betrachtet. Das Anfärben des Pilzes auf der Kartoffeloberfläche mit Calcofluor war erfolgreich (Abb. 10). 


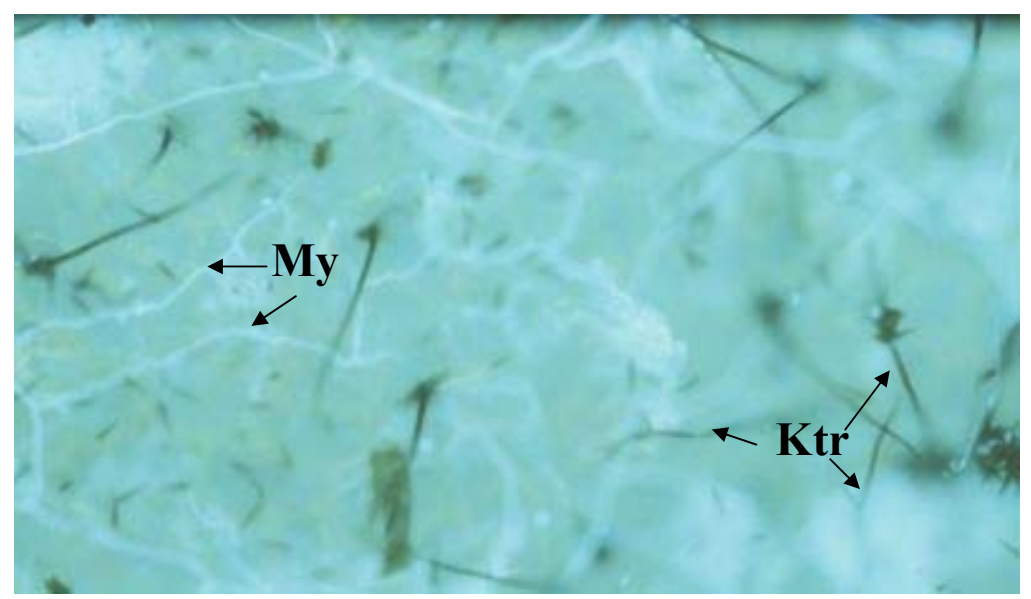

Abbildung 10: Mit Calcofluor angefärbtes Mycel von $H$. solani unter dem Fluoreszenzmikroskop 30facher Vergrößerung. Befallene Kartoffeloberfläche wurde entnommen, 5 min 0,1\% Calcofluor eingefärbt, anschließend in $25 \%$ Glycerin für $30 \mathrm{~min}$ gewaschen und unter dem Mikroskop fotografiert. $\mathrm{My}=$ Myzel; Ktr= Konidienträger

Bei der Anfärbung des Pilzes im Knollengewebe konnte aber keine geeignete Methode zum Anfärben des Pilzmycels gefunden werden. Dies lag bei der Färbung mit Comassie -Brilliant - Blau an dem Vorhandensein von Speicherstärke, die durch Aufnehmen des Farbstoffs ein differenziertes Anfärben des Pilzes verhinderte. Zum anderen wurde der Einsatz von Fluoreszenzfarbstoffen durch die Eigenfluoreszenz der Zellen verhindert. Lasermikroskopische Aufnahmen wurden ebenfalls in Betracht gezogen. Da hierbei jedoch ebenfalls Fluoreszenzfarbstoffe zum Einsatz kommen, schien auch diese Methode nicht sinnvoll. Es konnten aber unter dem Fluoreszenzmikroskop gute Aufnahmen der durch Silberschorf zerstörten Periderm-Cortexschicht als Vergleich zu gesunden Gewebeproben gemacht werden (Abb. 11).
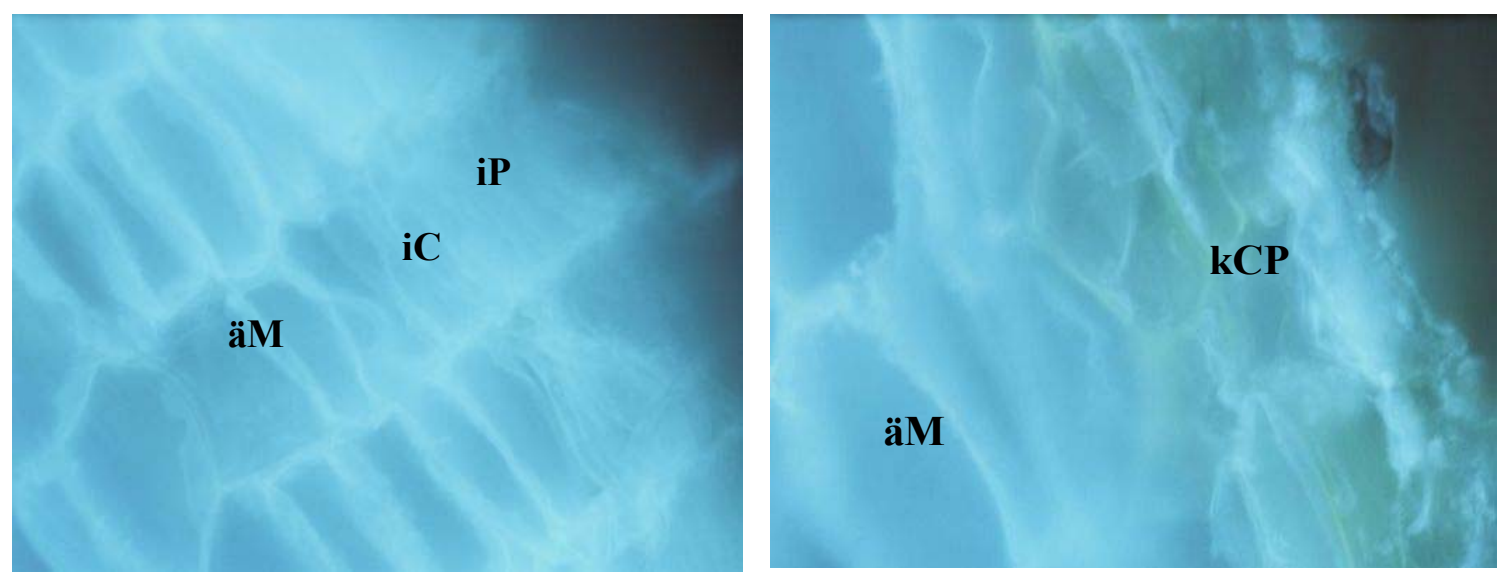

Abbildung 11: Mit Calcofluor angefärbte Gewebeproben von gesundem und mit $\boldsymbol{H}$. solani befallenem Knollengewebe unter dem Fluoreszenzmikroskop bei 100facher Vergrößerung. A zeigt die nicht infizierte Probe mit Periderm- und Cortexschicht. äM=äußere Markschicht; iC=intakter Cortex; iP= intaktes Periderm; B zeigt das kollabierte Periderm, sowie die angegriffene Cortexschicht. äM= äußere Markschicht; $\mathrm{kCP}=$ kollabierter Cortex und Periderm; 


\subsection{Biochemische Abwehrmechanismen}

\subsubsection{Dünnschichtchromatographie und Bioassay}

Zur Untersuchung möglicher Phytoalexine wurden Dünnschichtchromatographien und Bioassays durchgeführt. Für die Dünnschichtchromatographie wurden von allen zwölf im Feld untersuchten Knollensorten Schalenproben aufgereinigt. Dabei wurden jeweils eine Probe von gesundem Gewebe als Kontrolle sowie eine Probe von Silberschorf befallenem Gewebe wie beschrieben aufgereinigt. Die Proben der einzelnen Sorten wurden jeweils nebeneinander auf die DC - Platten gegeben und die Chromatographie durchgeführt. Nach Abtrocknung der Platten wurden diese mit Cladosporium sp. Sporen besprüht um Pathogen relevante Inhaltsstoffe der Schalen zu erfassen. H. solani selbst wächst viel zu langsam, um für einen Bioassay tauglich zu sein. Nach Inkubation wurden die Platten mit der Kamera dokumentiert (Abb. 12).
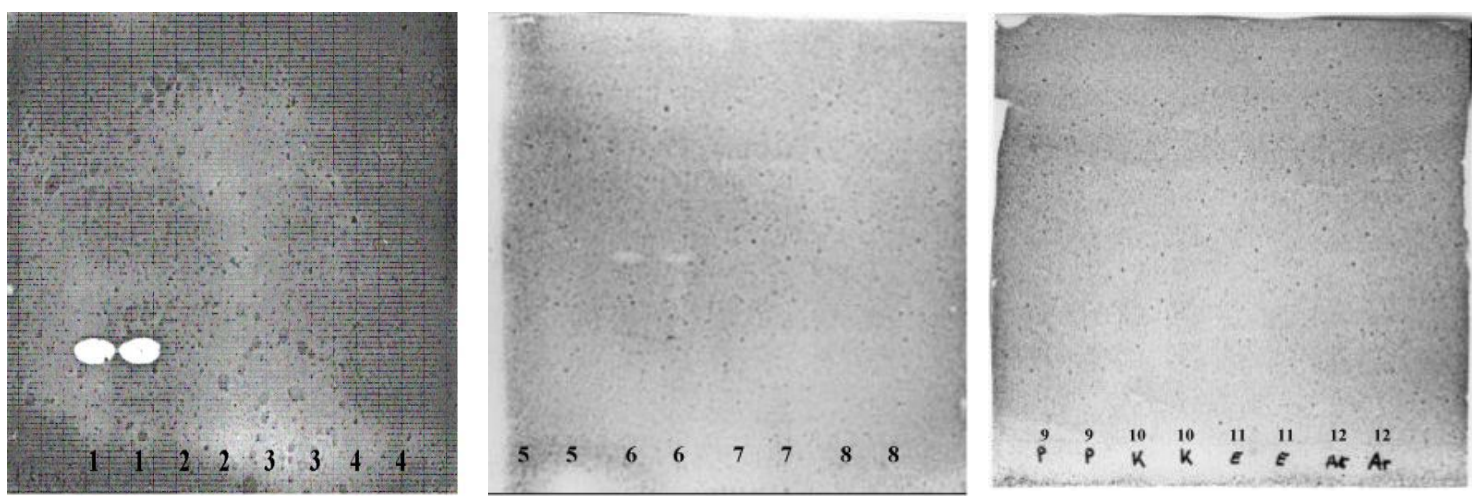

Abbildung 12: Bioassay nach Dünnschichtchromatographie. Es wurden Knollen aller Sorten aus den Feldversuchen überprüft, wobei immer zuerst die gesunde Pflanzenprobe als Kontrolle gefolgt von der kranken Pflanzenprobe aufgetragen wurde. $1=$ Bernadette, $2=$ Laura, $3=$ Solara, $4=$ Acapella, $5=$ Franzi $6=$ Marabel, $7=$ Secura, $8=$ Nicola, $9=$ Princess, $10=$ Karlena, $11=$ Edelstein, $12=$ Arcula

Bei den meisten Sorten konnten keine Hemmhöfe, weder bei den Proben mit gesundem, noch mit krankem Gewebe festgestellt werden. Nur die Sorten Bernadette (1) und Marabel (6) produzierten eine Pilzwachstum hemmende Substanz. Diese wurde dabei sowohl in der gesunden als auch in der kranken Pflanzenprobe gefunden. Bei der Sorte Bernadette waren die Hemmhöfe immer stark ausgeprägt und erschienen nach ca. 5,7 $\mathrm{cm}$ Laufweite. Die wachstumshemmenden Stoffe der Sorte Marabel waren in allen Wiederholungen relativ schwach und erschienen nach einer Laufweite von ca. 7,6 cm. Diese Ergebnisse konnten in keinen Zusammenhang mit den im Feld, Lager und Gewächshaus gefundenen Anfälligkeitsdaten gebracht werden. 


\subsubsection{Phytoalexine}

Um zu überprüfen, in wieweit es sich bei den gefundenen Stoffen um Phytoalexine handelt, wurde eine HPLC-Analyse durchgeführt. Es wurden nur die Proben des gesunden als auch des kranken Gewebes der Sorten Bernadette und Marabel untersucht, da nur hier pathogenrelevante Inhaltsstoffe gefunden wurden. Es konnten in keiner Probe aus Kartoffeln bekannte Phytoalexine nachgewiesen werden.

\subsubsection{Quantitative Analyse phenolischer Verbindungen}

Um zu überprüfen in wieweit die verschiedenen Sorten unterschiedliche Mengen phenolischer Verbindungen in die Schale einlagern, wurden Schalenproben aller im Feld getesteten Sorten wurden wie beschrieben aufgereinigt. im Photometer gemessen. Dabei wurde zunächst keine Differenzierung der phenolischen Verbindungen vorgenommen (Graphik 45). Da eine Eichung der Methode nach MENDEN (1995) nicht möglich ist wurden die Ergebnisse wie von MENDEN (1995) vorgeschlagen in Millieextinktionseinheiten pro mg eingesetzter Zellwandprobe angegeben, es handelt sich also um einen relativen Vergleich der Sorten zueinander.

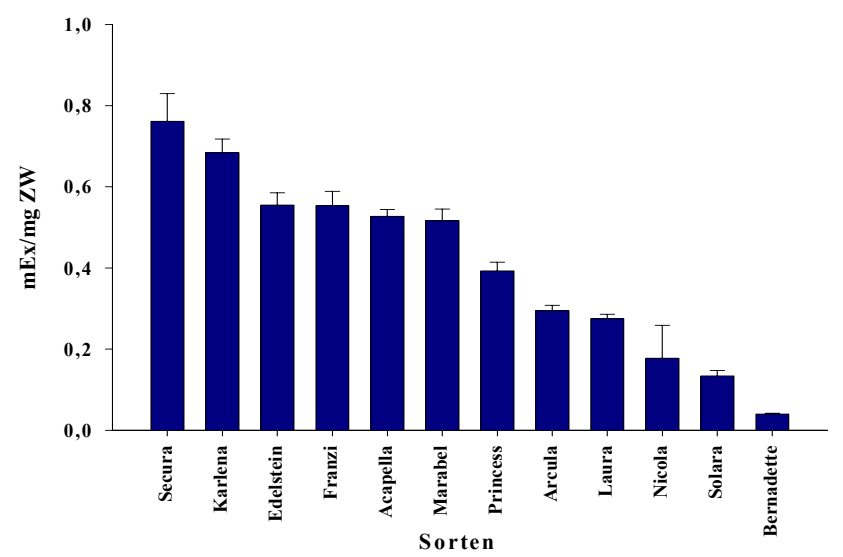

Graphik 45: Quantitativer Ligningehalt der Schale der 12 im Feld getesteten Kartoffelsorten. Auf der x-Achse sind die Sorten, auf der y-Achse die Millieextinktionseinheiten pro mg eingesetzter Zellwand angegeben. Die Intervalle geben die Standardabweichungen der drei durchgeführten Messreihen an. $7 \mathrm{mg}$ Schalenproben pro Sorte wurden wie beschrieben mit Thioglycolsäure aufgereinigt und ein 1:10 Verdünnung im Photometer bei $380 \mathrm{~nm}$ gemessen. Die Ergebnisse sind in Millieextinktionseinheiten pro $\mathrm{mg}$ eingesetzter Zellwandprobe angegeben. Eine Eichung der Millieextinktionseinheiten ist nicht möglich, daher handelt es sich um einen relativen Vergleich der Sorten zueinander. 
Demnach lagern die Sorten Secura, Karlena, Edelstein und Franzi besonders viel phenolische Komponenten in ihre Schale ein, während Sorten wie Bernadette, Solara, Nicola und Laura nur wenige phenolische Verbindungen in die Schale einlagern. Es wurde eine Regression zwischen dem Gehalt an phenolischen Verbindungen und der in Feld, Lager und Gewächshaus ermittelten Anfälligkeit der Sorten errechnet. Der Regressionskoeffizient betrug 0,29, im Durbin-Watson-Test konnte keine signifikante Beziehung (n.s.) zwischen den beiden Parametern gefunden werden.

\subsubsection{Qualitative Analyse phenolischer Verbindungen mittels HPLC}

Für die qualitative Analyse der phenolischen Verbindungen sollte eine HPLC optimiert und durchgeführt werden. Als erstes mussten Standards aller in Schalenproben der Kartoffel vermuteten Hydroxyzimtsäurederivate und Benzoesäurederivate sowie deren korrespondierende Aldehyde mit geeigneter Säule, Flussrate und Laufmittelgradient erarbeitet werden. Als Säule wurde eine Synergi HydroRP - 18250 x 4,6 mm Säule gewählt, die Läufe konnten bei Raumtemperatur durchgeführt werden. Eine optimale Auftrennung konnte bei keiner Flussrate erreicht werden, da sich in jedem Fall einige der Substanzen in ihrer Retentionszeit überlagerten. Eine gute Trennung wurde bei einer Flussrate von $0,5 \mathrm{ml} / \mathrm{min}$ erreicht, hier überlagerten sich nur 4 Standardsubstanzen (Graphik 46, Tab. 13). Diese Substanzen konnten dagegen jedoch bei einer Flussrate von $1 \mathrm{ml} / \mathrm{min}$ erfolgreich getrennt werden (Graphik 47, Tab. 13). 


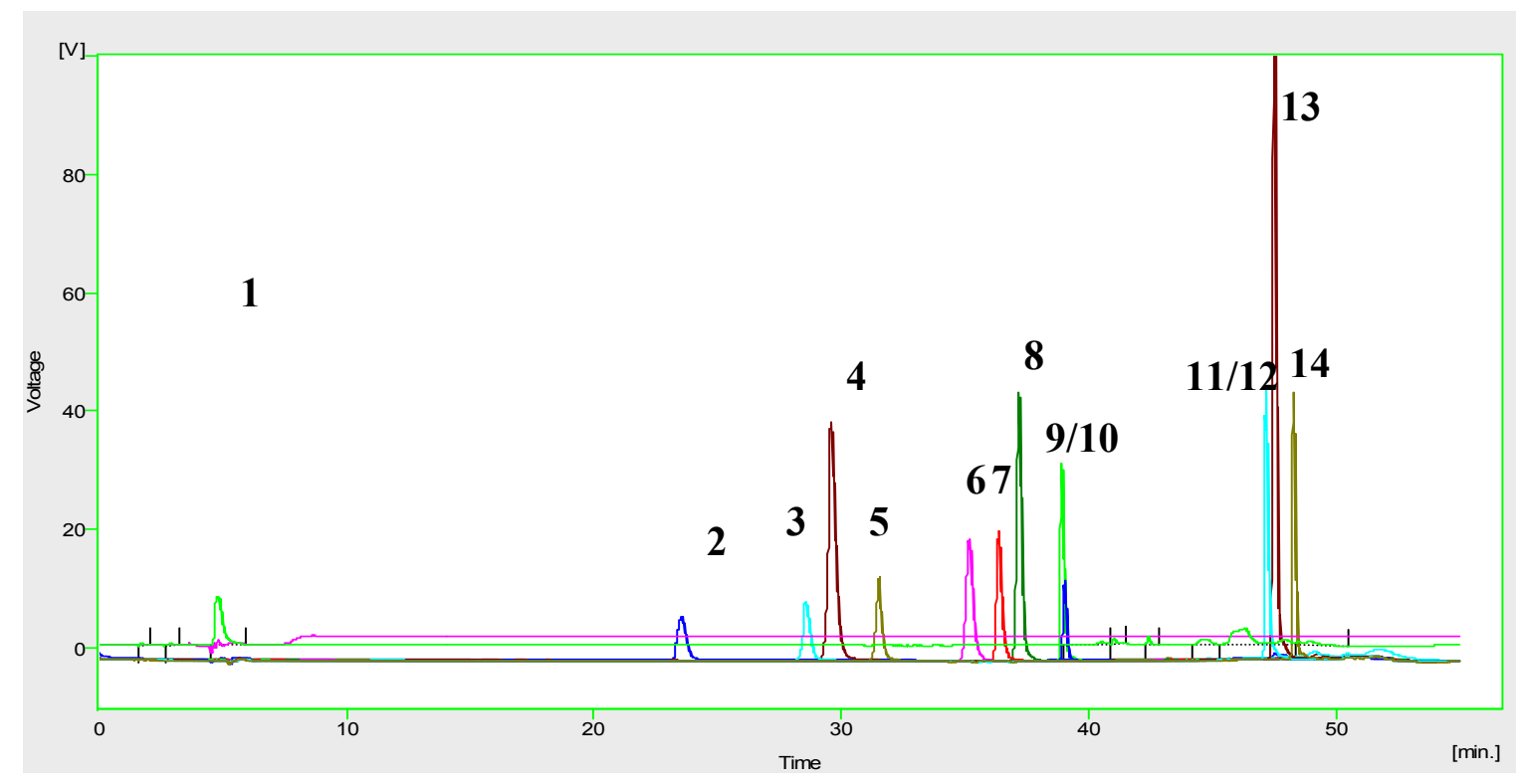

Graphik 46: Auftrennung der Standardsubstanzen bei einer Flussrate von $0,5 \mathrm{ml} / \mathrm{min}$. Auf der $\mathrm{x}$ - Achse ist der zeitliche Verlauf, auf der y-Achse die Spannung in Volt angegeben. Die jeweiligen Substanzen sind der Nummerierung der Peaks entsprechend in Tabelle 13 dargestellt. Als Laufmittel A wurde Methanol, als Laufmittel B 5\% Ameisensäure gewählt. Als Säule diente eine Synergi HydroRP-18 250x4,6mm Säule. Der Laufmittelgradient ist in Tabelle 14 wiedergegeben.

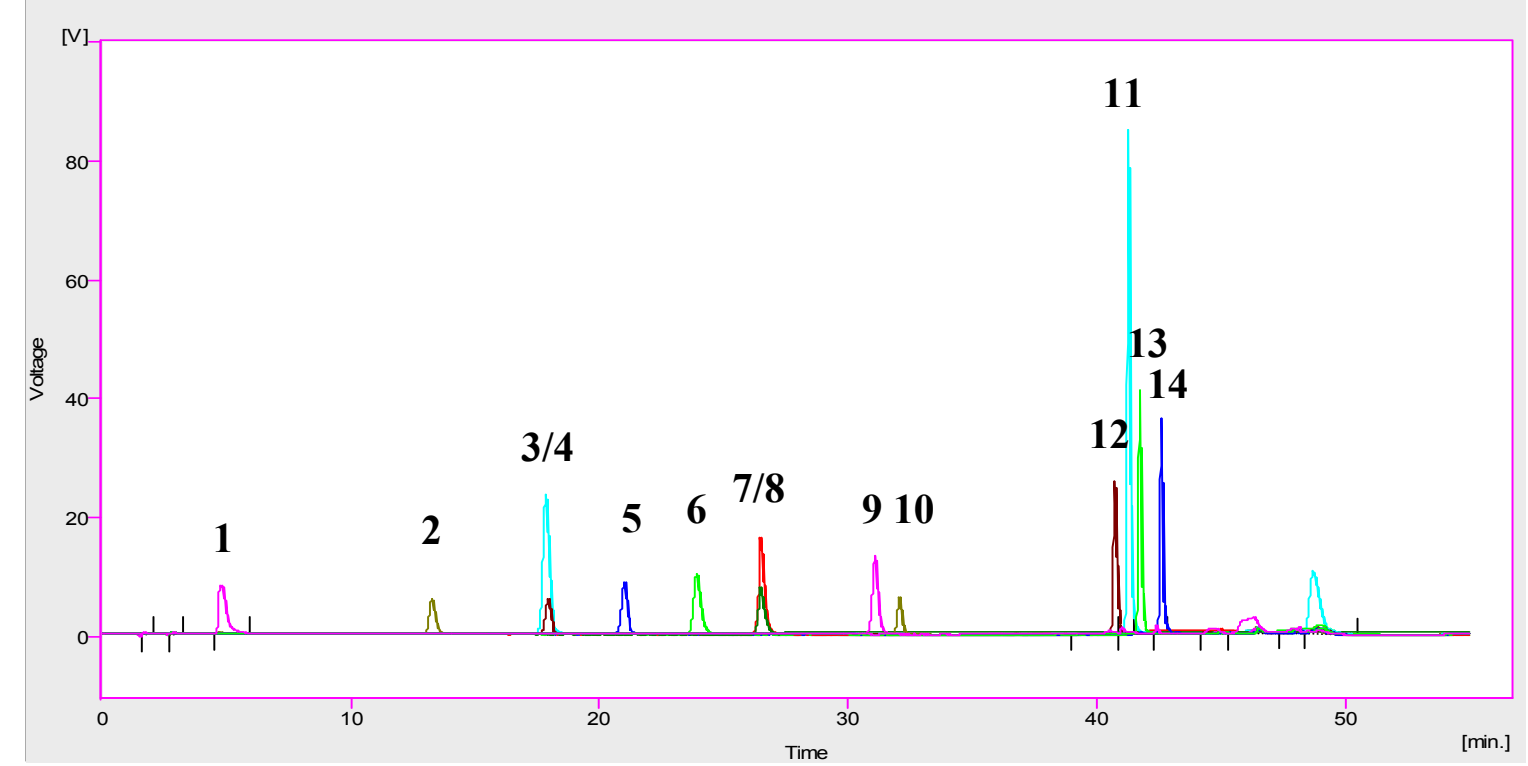

Graphik 47: Auftrennung der Standardsubstanzen bei einer Flussrate von $1 \mathrm{ml} / \mathrm{min}$. Auf der $\mathrm{x}$-Achse ist der zeitliche Verlauf, auf der y-Achse die Spannung in Volt angegeben. Die jeweiligen Substanzen sind der Nummerierung der Peaks entsprechend in Tabelle 13 dargestellt. Als Laufmittel A wurde Methanol, als Laufmittel B 5\% Ameisensäure gewählt. Als Säule diente eine Synergi HydroRP-18 250x4,6mm Säule. Der Laufmittelgradient ist in Tabelle 14 wiedergegeben. 
Tabelle 13: Retentionszeiten der Standardsubstanzen der HPLC für phenolische Verbindungen in Kartoffelschalen. Es werden die Flussraten $0,5 \mathrm{ml} / \mathrm{min}$ und $1 \mathrm{ml} / \mathrm{min}$ der 14 Standardsubstanzen miteinander verglichen.

\begin{tabular}{|l|l|l|}
\hline \multicolumn{1}{|c|}{$\begin{array}{c}\text { Standardsubstanz } \\
\text { (PCA) }\end{array}$} & $\begin{array}{c}\text { Retentionszeit / } \\
\mathbf{1 m l} / \mathbf{m i n} \\
\text { Flussrate (fr) }\end{array}$ & $\begin{array}{c}\text { Retentionszeit / } \\
\mathbf{0 , 5 m l} / \mathbf{m i n} \text { Flussrate } \\
\text { (fr) }\end{array}$ \\
\hline 1 Gallussäure & $4,8 \mathrm{~min}$ & $4,9 \mathrm{~min}$ \\
\hline 2 Hydroxybenzoesäure & $13,2 \mathrm{~min}$ & $23,5 \mathrm{~min}$ \\
\hline 3 Vanillinsäure & $17,9 \mathrm{~min}$ & $28,6 \mathrm{~min}$ \\
\hline 4 Hydroxybenzaldehyd & $17,8 \mathrm{~min}$ & $29,6 \mathrm{~min}$ \\
\hline 5 Syringasäure & $21,1 \mathrm{~min}$ & $31,5 \mathrm{~min}$ \\
\hline 6 Vanillin & $23,9 \mathrm{~min}$ & $35,2 \mathrm{~min}$ \\
\hline 7 Syringaaldehyd & $26,5 \mathrm{~min}$ & $36,5 \mathrm{~min}$ \\
\hline 8 p - Cumarsäure & $26,5 \mathrm{~min}$ & $37,2 \mathrm{~min}$ \\
\hline 9 Ferulasäure & $31,2 \mathrm{~min}$ & $38,9 \mathrm{~min}$ \\
\hline 10 Sinapinsäure & $32,1 \mathrm{~min}$ & $39,1 \mathrm{~min}$ \\
\hline 11 Dimethoxybenzaldehyd & $41,3 \mathrm{~min}$ & $47,2 \mathrm{~min}$ \\
\hline 12 Zimtsäure & $40,7 \mathrm{~min}$ & $47,5 \mathrm{~min}$ \\
\hline 13 Methoxyzimtsäure & $41,8 \mathrm{~min}$ & $47,8 \mathrm{~min}$ \\
\hline 14 Dimethoxizimtsäure & $42,6 \mathrm{~min}$ & $48,3 \mathrm{~min}$ \\
\hline & & \\
\hline
\end{tabular}

Daher wurden die Läufe mit Kartoffelproben zunächst bei einer Flussrate von 0,5 $\mathrm{ml} / \mathrm{min}$ durchgeführt. Erschienen Signale im Bereich der sich überlagernden Standardsubstanzen, wurde der Lauf bei einer Flussrate von $1 \mathrm{ml} / \mathrm{min}$ wiederholt. Als Laufmittel A wurde Methanol, als Laufmittel B 5\%ige Ameisensäure verwendet. Der Laufmittelgradient wurde ebenfalls variiert, um eine optimale Trennung zu erreichen. Am besten geeignet stellt sich der in Tab. 14 dargestellte Laufmittelgradient dar.

Tabelle 14: Optimaler Laufmittelgradient für die chromatische Trennung von phenolischen Verbindungen aus Kartoffelschalen mit HPLC. Laufmittel A ist Methanol, Laufmittel B 5\% Ameisensäure. In den angegebenen Zeitintervallen wurde die Zusammensetzung des Laufmittels verändert.

\begin{tabular}{|c|c|c|}
\hline \% Methanol & \% Ameisensäure (5\%ig) & Zeitintervall (min) \\
\hline 07 & 93 & 02.00 \\
\hline 15 & 85 & 06.00 \\
\hline 30 & 70 & 20.00 \\
\hline
\end{tabular}




\begin{tabular}{|c|c|c|}
\hline 80 & 20 & 18.00 \\
\hline 7 & 93 & 14.00 \\
\hline
\end{tabular}

Da die meisten Lignine und dessen Vorstufen in Pflanzenzellen zellwandgebunden sind, ist die Extraktion aus den Schalen sehr schwierig. Daher musste zunächst eine geeignete Methode zur Isolierung von phenolischen Verbindungen aus Kartoffelschalen gefunden werden, durch die eine anschließende qualitative Analyse mittels der optimierten HPLC möglich war. Dazu wurde die alkalische Hydrolyse, wie in Getreideblättern üblich, getestet. Trotz mehrfacher Wiederholung und Modifikationen konnten in der anschließenden HPLC-Analyse keine der standardisierten phenolischen Verbindungen nachgewiesen werden (Graphik 48). Der interne Standard wurde bei einer Laufrate von 0,5 ml/min nach 38,5 min von der Säule gewaschen. Bei manchen Proben, wie z.B. in der dargestellten, wurden kleine Mengen einer unbekannten Substanz nach ca. 18,3 min bei einer Laufrate von 0,5 $\mathrm{ml}$ von der Säule gewaschen, die jedoch mit keiner der Standardsubstanzen in Verbindung gebracht werden konnte.

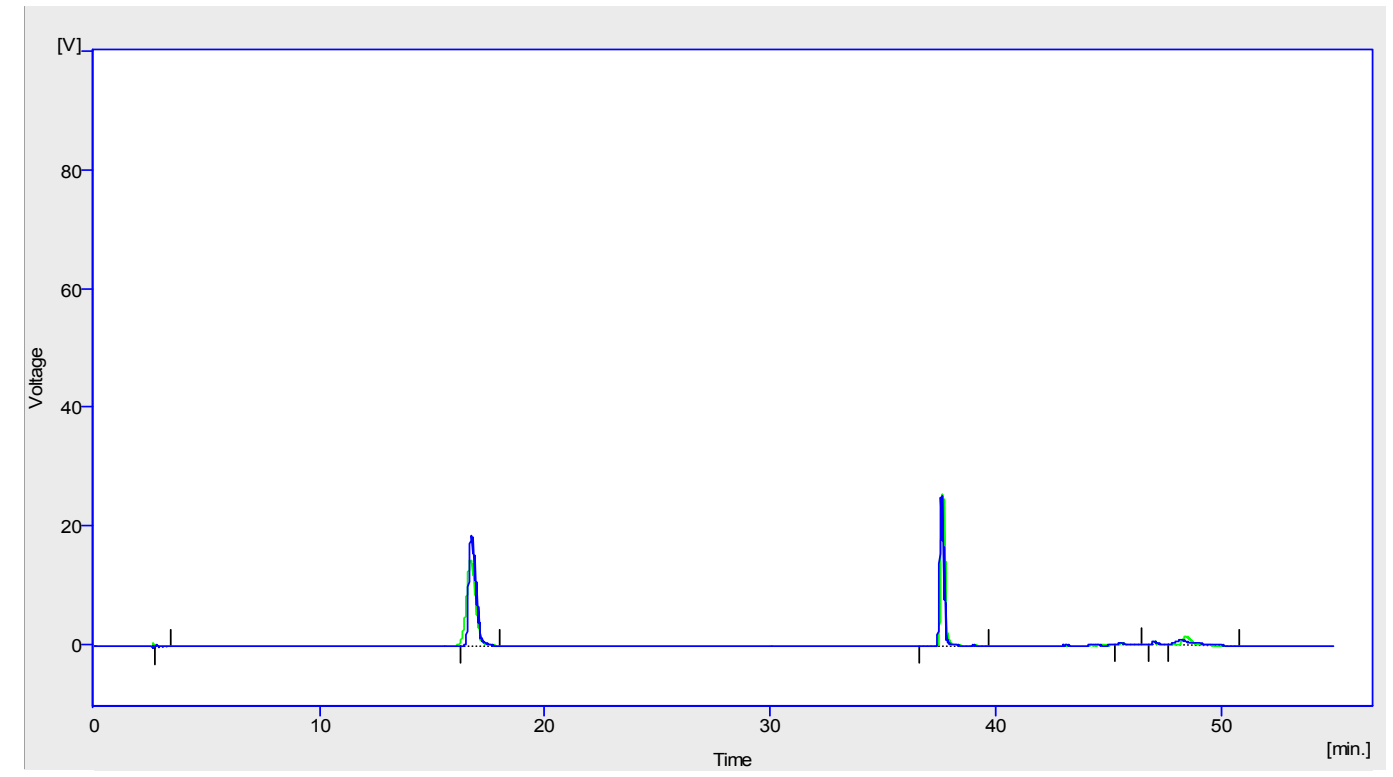

Graphik 48: HPLC des Schalenextrakts aus Secura bei einer Laufrate von $0,5 \mathrm{ml} / \mathrm{min}$. Auf der $\mathrm{x}$ - Achse ist die Zeit in min, auf der $\mathrm{y}$ - Achse die Spannung in Volt angegeben. Diese Graphik steht stellvertretend für alle untersuchten Proben. Es konnten keine phenolischen Verbindungen nachgewiesen werden. Der Ausschlag bei 18,3 min zeigt eine unbekannte Substanz, die in einer Schalenprobe der Sorte Secura gefunden wurde. In Proben anderer Knollen gleicher Sorte wurde die Substanz nicht nachgewiesen. Der Ausschlag bei 38,5 min wird durch die Standardsubstanz p - Anissäure hervorgerufen. 


\section{5 Übertragung von $\boldsymbol{H}$. solani von Mutter- auf Tochterknollen}

\subsection{Passive Übertragung über das Bodenwasser}

\subsubsection{Split root Test}

Jeweils 3 Knollen der Sorten Marabel, Arcula, Karlena, Edelstein und Princess wurden wie beschrieben auf Steinen gepflanzt, das Wurzelsystem geteilt und die Pflanzen in jeweils zwei Töpfe gepflanzt. Bei der Ernte konnten in den jeweils zweiten Töpfen mit steriler Erde keine Tochterknollen gefunden werden, auch Stolonen waren nicht bis in den zweiten Topf gewachsen. Auch nach zweifacher Wiederholung und Modifikation des Versuchsablaufs wurden keine Tochterknollen oder Stolonen im zweiten Topf mit steriler Erde geerntet. Daher wurden am Institut für Pflanzenpathologie und Pflanzenschutz speziell für die Überprüfung der Übertragung von Konidien Rinnenversuche entwickelt, deren Ergebnisse im Folgenden beschrieben werden.

\subsubsection{Rinnenversuche}

Knollen der Sorte Karlena wurde am oberen Ende der Rinnen gepflanzt und ab dem Auflaufen der Pflanzen die Probennahme wie beschrieben durchgeführt (Abb.13). Es wurden insgesamt 15 Proben während der Vegetationsperiode genommen und Mittelwerte der gefundenen Konidienzahl pro Durchlaufloch errechnet. Der Versuch wurde wiederholt, die Daten verrechnet und in Graphik 53 dargestellt. 

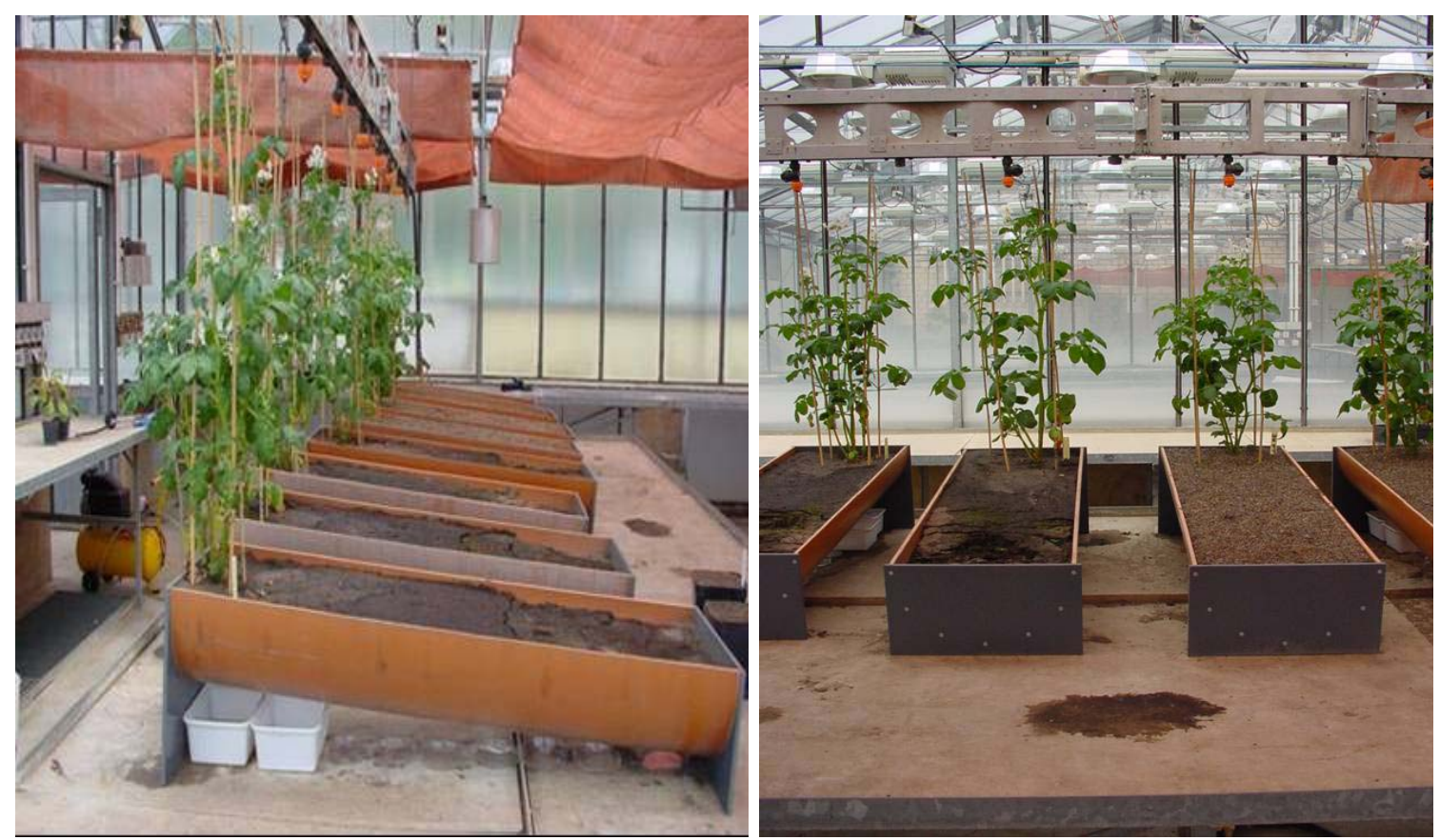

Abbildung 13: Rinnenversuche im Gewächshaus. Die Knollen wurden am oberen Ende einer schräg aufgestellten, $1 \mathrm{~m}$ langen Rinne gepflanzt. In der Rinne befinden sich alle $10 \mathrm{~cm}$ Löcher zum Ablauf des Gieswassers. Unter diesen Löchern sind Behälter aufgestellt, die das Durchlaufwasser auffangen. Dieses Wasser wird anschließend mikroskopisch auf $H$. solani Konidien untersucht.

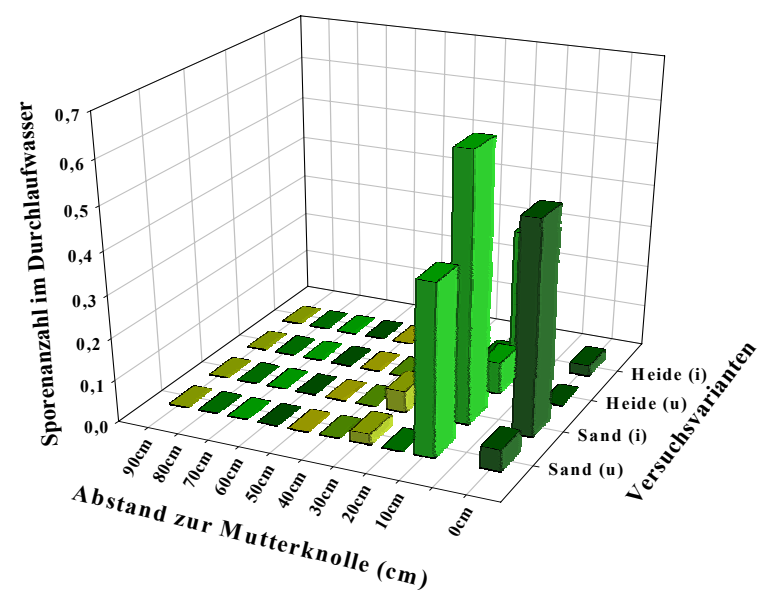

Graphik 53: Konidientransport im Bodenwasser (Rinnenversuch). Auf der $x$-Achse ist der Abstand von der Mutterknolle in cm, auf der y-Achse die Konidienzahl im Durchlaufwasser und auf der $\mathrm{z}$-Achse die Versuchsvarianten dargestellt. Die Wassermenge pro Durchlaufloch konnte nicht festgelegt werden, da natürlicherweise die Durchlaufmenge in den zur Pflanzknolle nächstgelegenen Löchern wesentlich größer war als in den jeweils entfernteren. Sand = Sandboden; Heide $=$ Heideboden; $\mathrm{u}=$ unbehandelt; $\mathrm{i}=$ inokuliert; es liegt kein signifikanter Unterschied zwischen den inokulierten und den unbehandelten Varianten vor $(\mathrm{t}-$ Test. $\mathrm{p} \leq$ $0,05)$. 
Der Versuch ergab, dass nur sehr wenige Konidien insgesamt mit dem Wasser transportiert wurden. Im Höchstfall wurden 0,62 Konidien gefunden. Die meisten Konidien wurden im Durchlauf nach 0-10 cm gefunden, nur sehr wenige nach 20 oder $30 \mathrm{~cm}$. Ab $40 \mathrm{~cm}$ wurden überhaupt keine Konidien mehr im Durchlaufwasser gefunden. Dabei wurden im Sandboden mehr Konidien transportiert als im Heideboden. Es bestand kein signifikanter Unterschied zwischen inokulierter und unbehandelter Variante. Ein leichter und häufiger Transport der Konidien über Bodenwasser konnte somit nicht gezeigt werden.

\subsubsection{Bodensuppressivitätstest}

Im Bodensuppressivitätstest wurde untersucht, in wieweit verschiedene Böden eine suppressive Wirkung auf die Keimung von $H$. solani Konidien haben. Als Testisolat wurde der von der Biologischen Bundesanstalt zur Verfügung gestellte H. solani Stamm BBA verwendet. Es wurde Boden aus der Heide, von den drei Feldversuchen und einem Standort bei Göttingen, der noch nie mit Kartoffeln bepflanzt war, verwendet. Neben dem unbehandelten Boden wurde jeweils eine autoklavierte Variante als Kontrolle mitgeführt (Tab. 15). Außerdem wurden die Celluloseacetatmembranen unter dem Fluoreszenzmikroskop dokumentiert (Abb. 14).

Tabelle 15: Vergleich der Bodensuppressivität von Böden verschiedener Herkunft. Es wurden fünf Böden getestet. Am Standort Wüstes Land wurden noch nie Kartoffeln kultiviert. Neben dem unbehandelten Boden wurde immer eine Negativkontrolle mit autoklaviertem Boden mitgeführt. Der Versuch wurde 3fach wiederholt mit gleichbleibendem Ergebnis.

\begin{tabular}{|l|c|c|}
\hline \multicolumn{1}{|c|}{ Bodenherkunft } & $\begin{array}{c}\text { Keimung der Konidien auf } \\
\text { autoklavierter Boden in \% }\end{array}$ & $\begin{array}{c}\text { Keimung der Konidien auf } \\
\text { unbehandelter Boden in \% }\end{array}$ \\
\hline Heide & $85-90 \%$ & $5-10 \%$ \\
\hline Groß Lüsewitz & $85-90 \%$ & $10-15 \%$ \\
\hline Windeby & $85-90 \%$ & $5-10 \%$ \\
\hline Kaltenberg & $85-90 \%$ & $5-10 \%$ \\
\hline Wüstes Land (Göttingen) & $90-95 \%$ & $10-15 \%$ \\
\hline
\end{tabular}



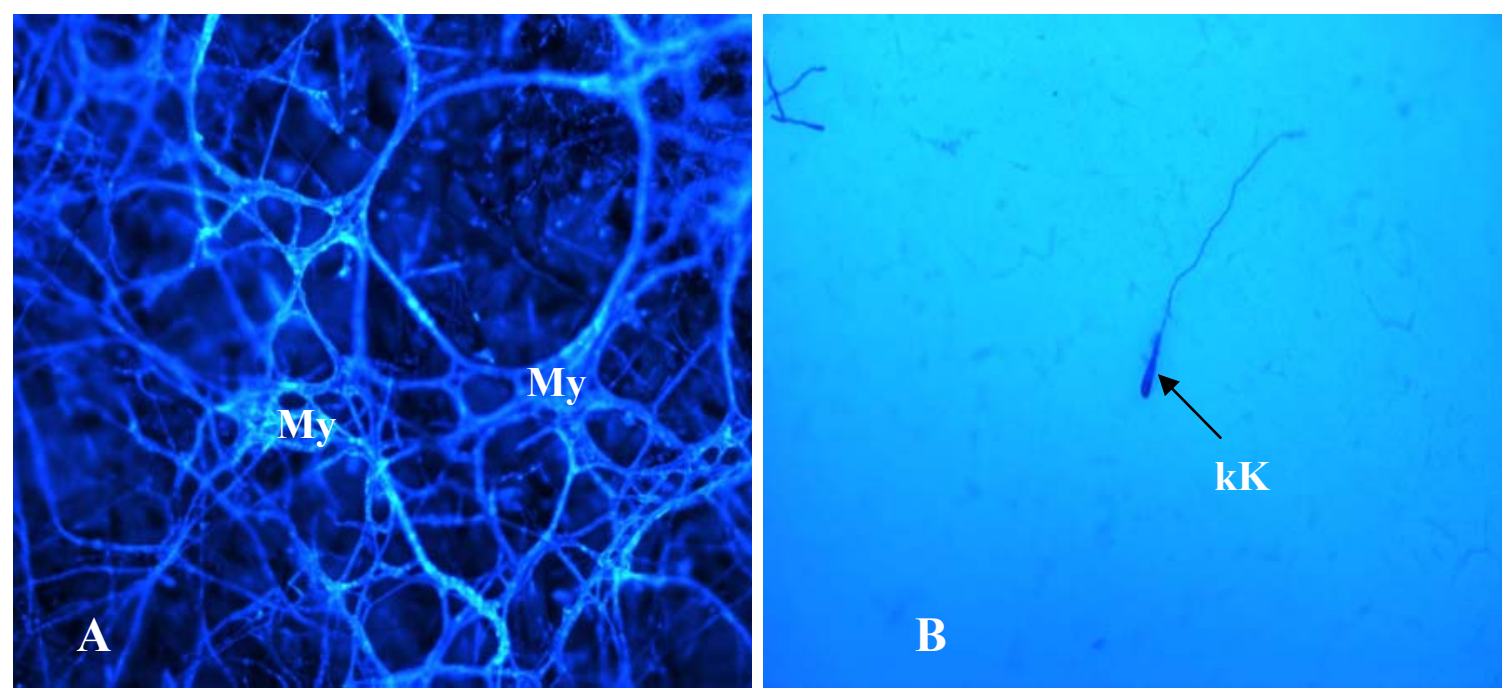

Abbildung 14: Einfluss der Bodensuppressivität auf die Keimung von $\boldsymbol{H}$. solani Konidien. Bild A zeigt die Variante mit autoklaviertem Boden.; My=Myzel; Bild B die Variante mit unbehandeltem Boden des Standorts Heide. Der Unterschied in der Keimungs- und Wachstumsfähigkeit ist deutlich zu erkennen. $\mathrm{kK}=$ keimende Konidie;

Bei allen Bodenproben wurde ein stark signifikanter Unterschied zwischen der autoklavierten und der unbehandelten Bodenprobe gefunden. Auf dem autoklavierten Boden waren immer zwischen 85-95 \% der Konidien gekeimt, während auf dem unbehandelten Boden nur 5-15 \% der Konidien zur Keimung gelangten. Dabei war kein Unterschied zwischen den verschiedenen Bodenproben zu erkennen, auch die Erdprobe von dem Schlag, auf dem noch nie Kartoffeln angepflanzt wurden, zeigte eine starke Suppression auf $H$. solani Keimung. Der Versuch wurde mehrfach wiederholt, das Ergebnis wurde immer bestätigt. Damit konnte eine Suppression von Boden auf die Keimung von $H$. solani Konidien nachgewiesen werden.

\subsubsection{Bodensuppressivitätstest mit Kartoffelwasser und enzymatische Zuckeranalyse}

Um zu testen, in wieweit die Anwesenheit von verschiedenen Kartoffelsorten die Keimung von $H$. solani Konidien wieder fördern kann, wurden je fünf Knollen aller im Feld untersuchten Kartoffelsorten in Wasser inkubiert, und der Boden des Suppressivitätstest mit diesem Wasser befeuchtet. Die Bodenbewässerung erfolgte nach 
1, 3 und 5 Tagen Inkubation der Knollen im eingesetzten Wasser. Nach einem Tag wurden die in Graphik 54 gefundenen Keimraten unter dem Mikroskop gefunden.

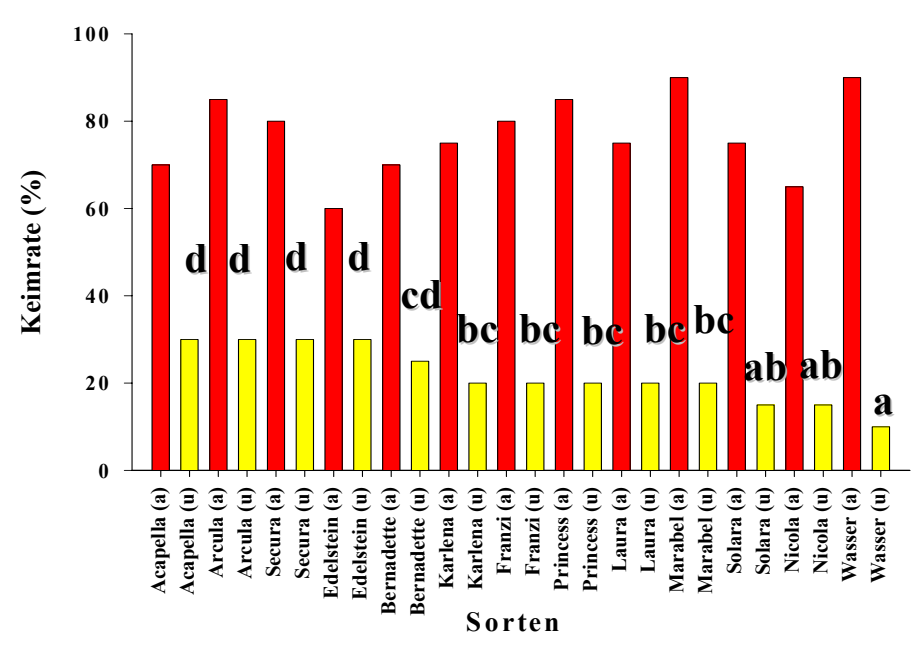

Graphik 54: Keimung der $H$. solani Konidien im Bodensuppressivitätstest mit Kartoffelwasser nach einem Tag Lagerung der Knollen (5 Knollen je Sorte) in Wasser. Auf der x-Achse sind die Sorten, auf der y-Achse die Keimraten in \% angegeben. (a) = autoklavierter Boden; $(\mathrm{u})=$ unbehandelter Boden; es bestehen bei der unbehandelten Variante signifikante Unterschiede zwischen der Wasserkontrolle und den Proben der Sorten AcapellaMarabel (bc, cd, d; t-Test, $\mathrm{p} \leq 0,05$ ). Nur die Sorten Solara und Nicola zeigen keinen signifikanten Unterschied ( $a b$; t-Test, $\mathrm{p} \leq 0,05)$. Sorteneffekte im autoklavierten Boden sind nicht signifikant.

Die Wasserproben aller Sorten zeigten einen Anstieg der Keimrate der H. solani Konidien im Vergleich zur Wasserprobe. Die Proben der Sorten Acapella, Arcula, Secura und Edelstein zeigten den deutlichsten Anstieg um ca. 20 \%, die der Sorten Nicola und Solara dagegen waren nur leicht um 5 \% gesteigert. Die Proben der Sorten Bernadette, Karlena, Franzi, Princess, Laura und Marabel zeigten einen mittleren Anstieg der Keimrate um etwa 10 \%. Im t-Test der unbehandelten Varianten wurden sortenbedingt signifikante Unterschiede der Sorten sowohl zur Wasserkontrolle als auch untereinander festgestellt ( $a, a b, b c, c d, d ; t-T e s t, p \leq 0,05)$. Nur die Sorten Solara und Nicola zeigten keinen signifikanten Unterschied zur Wasserkontolle.

Nach drei Tagen Lagerung wurden die in Graphik 55 dargestellten Keimraten gefunden. 


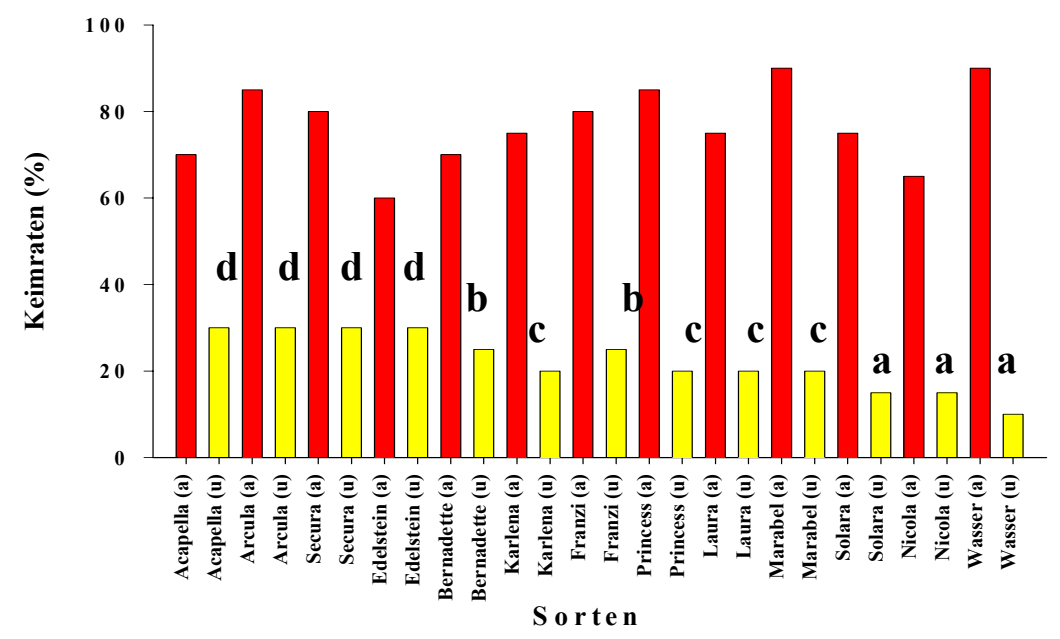

Graphik 55: Keimung der $H$. solani Konidien im Bodensuppressivitätstest mit Kartoffelwasser nach drei Tagen Lagerung der Knollen (5 Knollen je Sorte) in Wasser. Auf der $x$-Achse sind die Sorten, auf der $y$-Achse die Keimraten in \% angegeben. (a) = autoklavierter Boden; $(\mathrm{u})=$ unbehandelter Boden; es bestehen bei der unbehandelten Variante signifikante Unterschiede zwischen der Wasserkontrolle und den Proben der Sorten AcapellaMarabel (b, c, d; t-Test, $\mathrm{p} \leq 0,05)$. Nur die Sorten Solara und Nicola zeigen keinen signifikanten Unterschied ( $a$; $t$-Test, $\mathrm{p} \leq 0,05)$. Sorteneffekte im autoklavierten Boden sind nicht signifikant.

Die Wasserproben aller Sorten zeigten wiederum einen Anstieg der Keimrate der $H$. solani Konidien im Vergleich zur Wasserprobe. Die Proben der Sorten Acapella, Arcula, Secura und Edelstein zeigten wieder den deutlichsten Anstieg diesmal um ca. $25 \%$, die der Sorten Nicola und Solara dagegen waren nicht mehr als $5 \%$ gesteigert. Die Proben der Sorten Bernadette, Karlena, Franzi, Princess Laura und Marabel zeigten wiederum einen mittleren Anstieg der Keimrate diesmal um etwa $15 \%$. Im t-Test der unbehandelten Varianten wurden wiederum sortenbedingt signifikante Unterschiede der Sorten sowohl zur Wasserkontrolle als auch untereinander festgestellt (a; b; c; d; t-Test, $\mathrm{p} \leq$ 0,05). Nur die Sorten Solara und Nicola zeigten wiederum keinen signifikanten Unterschied zur Wasserkontolle.

Nach fünf Tagen Einlagerung der Knollen in Wasser und anschließendem Bodensuppressivitätstest wurden die in Graphik 56 gefundenen Keimraten ermittelt. 


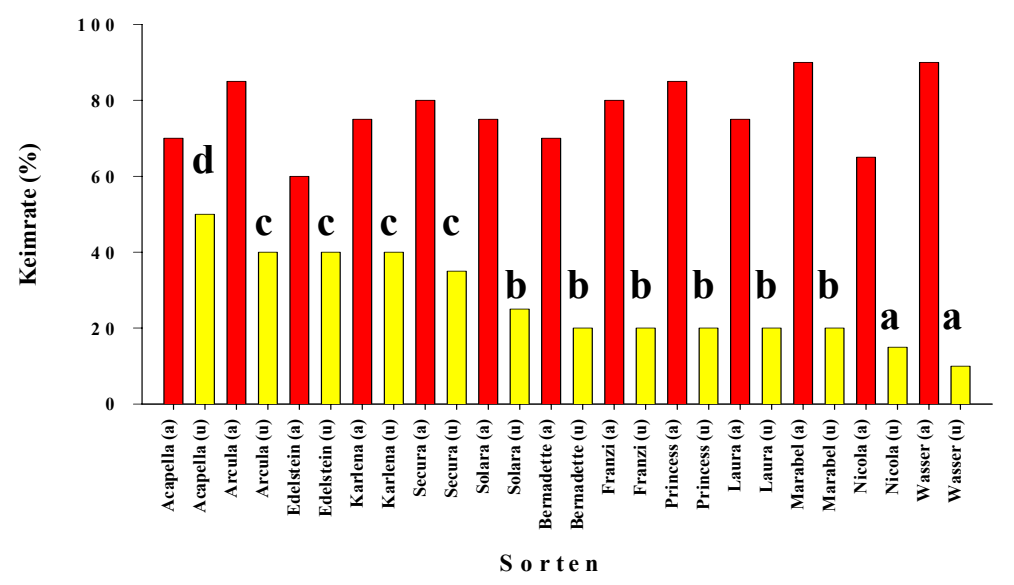

Graphik 56: Keimung der $H$. solani Konidien im Bodensuppressivitätstest mit Kartoffelwasser nach fünf Tag Lagerung der Knollen (5 Konllen je Sorte) in Wasser. Auf der $x$-Achse sind die Sorten, auf der y-Achse die Keimraten in \% angegeben. (a) = autoklavierter Boden; $(\mathrm{u})=$ unbehandelter Boden; es bestehen bei der unbehandelten Variante signifikante Unterschiede zwischen der Wasserkontrolle (a) und den Proben der Sorten Acapella-Marabel (b, c, d; t-Test, $\mathrm{p} \leq 0,05$ ). Nur die Sorte und Nicola zeigen keinen signifikanten Unterschied (a; t-Test, $\mathrm{p} \leq 0,05)$. Sorteneffekte im autoklavierten Boden sind nicht signifikant.

Die Proben aller Sorten zeigten erwartungsgemäß auch nach fünf Tagen Lagerung einen Anstieg der Keimrate der H. solani Konidien im Vergleich zur Wasserprobe. Dabei war der Anstieg der Proben der Sorten Acapella, Arcula, Karlena, Edelstein und Secura am deutlichsten mit diesmal 30-35 \%. Im Mittelfeld lag nach diesem Versuch nur die Probe der Sorte Solara mit einem Keimanstieg um 15 \%. Nur einen geringen Anstieg zeigten die Sorten Nicola, Princess, Franzi, Marabel, Bernadette und Laura um 5 - 10 \%. Im tTest der unbehandelten Varianten wurden wiederum sortenbedingt signifikante Unterschiede der Sorten sowohl zur Wasserkontrolle als auch untereinander festgestellt $(\mathrm{a} ; \mathrm{b} ; \mathrm{c} ; \mathrm{d} ; \mathrm{t}$-Test, $\mathrm{p} \leq 0,05)$. Nur die Sorte Nicola zeigte diesmal keinen signifikanten Unterschied zur Wasserkontolle.

Um eine Beziehung der Keiminduktion auf die Anfälligkeit der Sorten zu untersuchen, wurde eine Regression zwischen dem im Feld-, Lager- und Gewächshaus erstellten Sortenspektrum und den Daten des Suppressivitätsversuches mit 5tägiger Einlagerung der Knollen in Wasser errechnet (Graphik 57). Der Regressionskoeffizient lag bei 0,72***, der Durbin-Watson-Test ergab eine stark signifikante Beziehung zwischen Keimrate der H. solani Konidien und der Anfälligkeit der Sorten. 


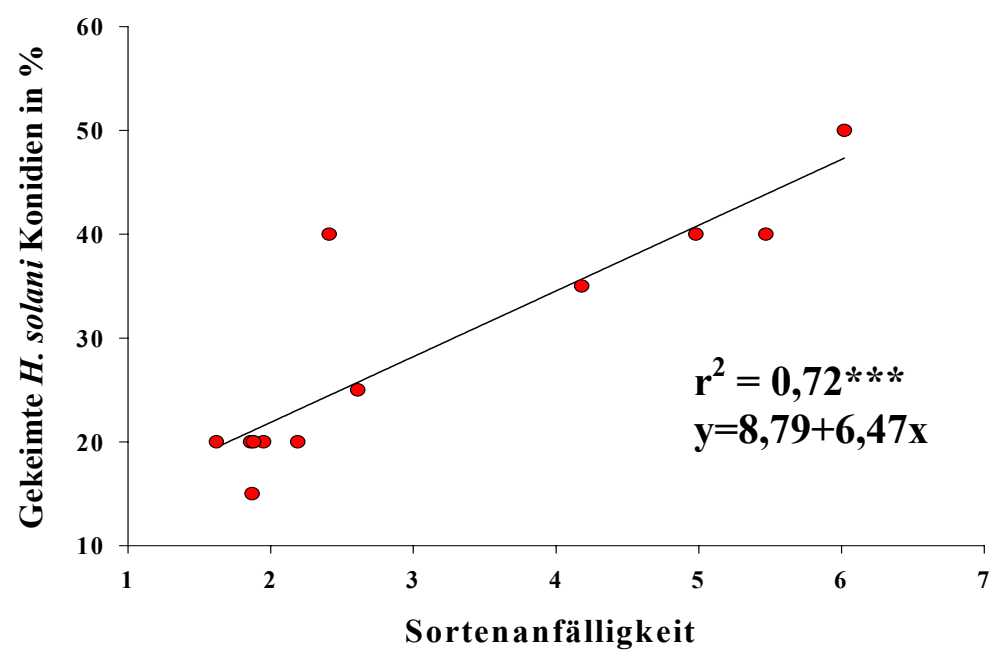

Graphik 57: Regression zwischen Keimrate der H. solani Konidien im Suppressivitätstest auf unbehandeltem Boden mit Kartoffelwasser nach 5tägiger Lagerung der Knollen in Wasser und der Anfälligkeit aus Feld, Lager und Gewächshaus. Auf der x-Achse ist die Anfälligkeit der Sorten von 1-7 gegen H. solani (vgl. Kapitel 6 aus Material und Methoden), auf der y-Achse die Keimrate in \% angegeben. Der Regressionskoeffizient beträgt 0,72***, nach dem Durbin-Watson-Test liegt eine hoch signifikante Beziehung zwischen den Parametern vor.

Als Kontrolle wurde ebenfalls eine Regression zwischen der Keimrate der H. solani Konidien auf autokaviertem Boden mit Kartoffelwasser nach 5tägiger Lagerung in Wasser und der im Feld, Lager unf Gewächshaus ermittelten Anfälligkeit der Knollen errechnet (Graphik 58). Es konnte wie erwartet keine Beziehung ziwschen den Parametern festgestellt werden, da der Regressionskoeffizient 0,004 beträgt und im Durbin Watson-Test keine Signifikanz festgestellt werden konnte.

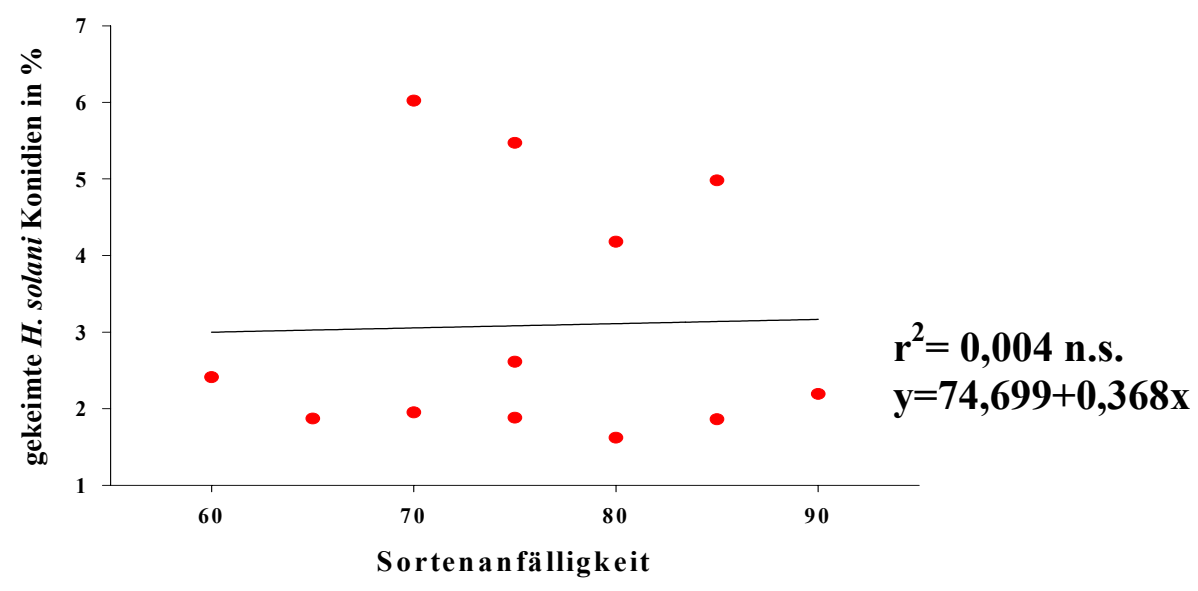

Graphik 58: Regression zwischen Keimrate der H. solani Konidien im Suppressivitätstest auf autoklaviertem Boden mit Kartoffelwasser nach 5tägiger Lagerung der Knollen in Wasser und der Anfälligkeit aus Feld, Lager und Gewächshaus. Auf der x-Achse ist die Anfälligkeit der Sorten von 1-7 gegen H. solani (vgl. Kapitel 6 aus Material und Methoden), auf der y-Achse die Keimrate in \% angegeben. Das Bestimmtheitsmass beträgt hier 0,004, nach dem Durbin-Watson-Test liegt keine signifikante Beziehung zwischen den Parametern vor. 
Um den Grund für die sortenspezifische Keiminduktion $\mathrm{zu}$ untersuchen, wurden enzymatische Zuckeranalysen mit dem Wasser, in dem die Knollen 5 Tage eingelagert waren, durchgeführt. Es wurde der Gehalt an D-Fructose, D-Glucose und Saccharose gemessen (Graphik 59).

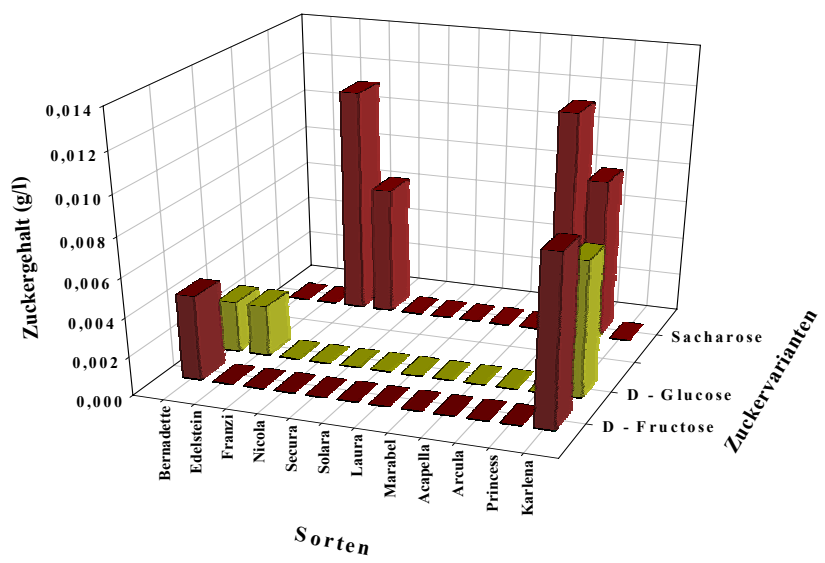

n.S.

Graphik 59: Zuckergehalte in den Wasserproben nach 5tägiger Lagerung der Knollen der verschiedenen Sorten. Auf der x-Achse sind die entsprechenden Sorten, auf der y -Achse der Zuckergehalt in g/l und auf den z-Achsen die Zuckervarianten Saccharose, D-Glucose und DFructose angegeben. Es konnte kein signifikanter Unterschied zwischen den Sorten und den Zuckergehalten ermittelt werden $(t-$ Test; $p \leq 0,05)$.

Der Zuckergehalt in den Wasserproben war insgesamt sehr gering. Nur in 9 von 36 Proben konnte überhaupt Zucker in sehr geringen Mengen nachgewiesen werden. Keine Zuckerart trat besonders häufig oder in großen Mengen auf. Ein sortenabhängiger Saccharose- /D - Glucose- /D - Fructosegehalt war nicht zu erkennen, da keine signifikante Beziehung zwischen Zuckerproduktion und Sorten bestand. Demnach konnte auch kein Zusammenhang zwischen der Keimratenerhöhung von H. solani Konidien und dem Zuckergehalt in den einzelnen Proben gefunden werden. 


\subsection{Untersuchung der Übertragung über Stolonen mittels PCR}

Um zu überprüfen, ob der Pilz auch in der Lage ist, mit den Stolonen von Mutterknolle zu Tochterknolle zu wachsen, wurden Proben der Stolonen, Wurzeln, Triebe und Schale mittels PCR auf $H$. solani überprüft. Als geeignete Aufreinigungsmethode zeigte sich das Invisorb®SPIN Plant Mini Kit der Firma INVITEK GmbH, Göttingen. Um die PCR selbst zu optimieren, wurden befallene Schalenproben untersucht und mit $H$. solaniDNA aus Reinkulturen gemischt. Damit sollte eine Störung der PCR durch pflanzliche bzw. andere pilzliche DNA ausgeschlossen werden. Die Primernpaare ITS4-ITS5, HSF120-HSR 465 und HSF 19-HSR 447 (nicht abgebildet) wurden getestet (Abb. 15).

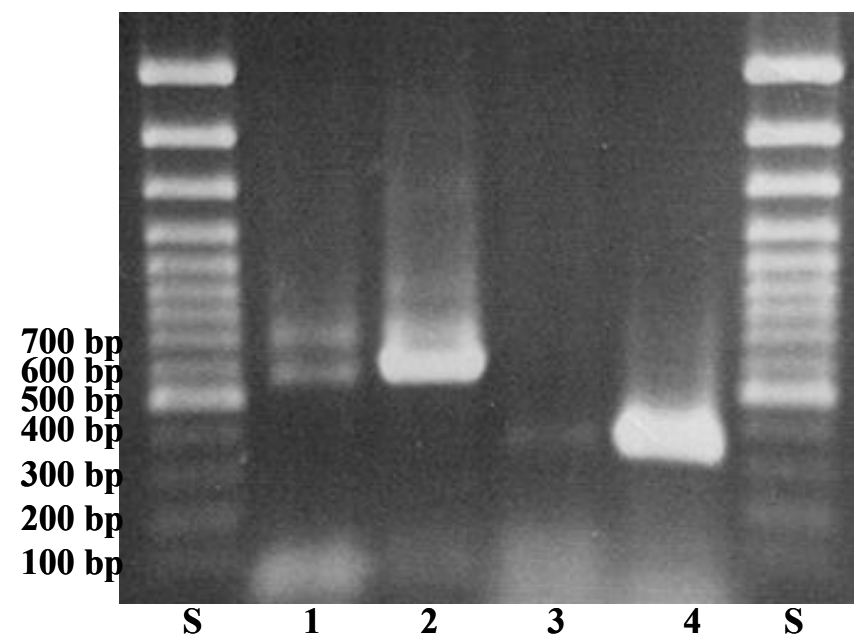

Abbildung 15: PCR Produkte der Positivkontrolle von $H$. solani DNA gemischt mit gesamt DNA aus Stolonenproben mit ITS4/5 und $H$. solani spezifischen Primern (HSF1 20-HSR 465). Es wurde ausgeschlossen, dass Fremd-DNA die PCR stört. S = Standard DNA in 100 bp Schritten; 1 = PCR mit ITS Primern mit DNA aus befallenem Schalenmaterial, 2 = PCR mit ITS Primern mit DNA aus befallenem Schalenmaterial gemischt mit $H$. solani DNA aus Sterilkultur; $3=$ PCR mit $H$. solani spezifischen Primern mit DNA aus befallenem Schalenmaterial; 4=PCR mit $H$. solani spezifischen Primern mit DNA aus befallenem Schalenmaterial gemischt mit $H$. solani DNA aus Sterilkultur.

Das H. solani spezifische Primerpaar HSF 19 - HSR 447 ergab immer zahlreiche unspezifische Banden auf dem Gel, so dass damit nicht weitergearbeitet wurde (nicht abgebildet). Die mit S bezeichneten Spuren zeigen die Standard-DNA in 100 bp Schritten. Auf Bahn 1 wurden eine PCR mit ITS 4/5 mit dem H. solani befallenem Schalenmaterial durchgeführt. Das gewünschte DNA Fragment von 530 bp Länge konnte nachgewiesen werden. Da es sich bei ITS Primern um Universalprimer für Pilze handelt, wurde auch andere pilzliche DNA, die mit der Schalenprobe gereinigt wurden, erfasst. Damit lässt sich das weitere Fragment bei ca. 700 bp erklären. Auf Bahn 2 
wurde der DNA der Schalenprobe H. solani DNA aus Reinkulturen beigemischt und mit ITS Primern amplifiziert, was ein starkes Signal in der gewünschten Größe von 530 bp ergab. Somit stört Pflanzen-DNA, bzw. DNA anderer Pilze die Amplifikation der $H$. solani DNA nicht. Auf Bahn 3 wurde die PCR mit der DNA der Schalenprobe mit dem H. solani spezifischen Primerpaar HSF120- HSR 465 durchgeführt. Der Pilz konnte eindeutig nachgewiesen werden mit dem erwarteten DNA Fragment von 345 bp Länge. Auf Bahn 4 wurde der Schalenprobe die H. solani DNA aus Reinkulturen beigemischt und die PCR mit Primerpaar HSF120-HSR 465 wiederholt. Hier wurde ebenfalls ein Signal bei 345 bp aufgenommen. Damit konnte auch für die $H$. solani spezifischen Primer bestätigt werden, dass pflanzliche und andere pilzliche DNA die Amplifikation nicht stören. Als Negativkontrolle der pflanzlichen DNA wurden Meristemkartoffeln der Sorten Karlena und Acapella angezogen und die DNA aus Wurzeln, unterirdischem Triebteil als auch grünem Trieb extrahiert. Es wurden nestedPCR wie beschrieben durchgeführt (Abb. 16).

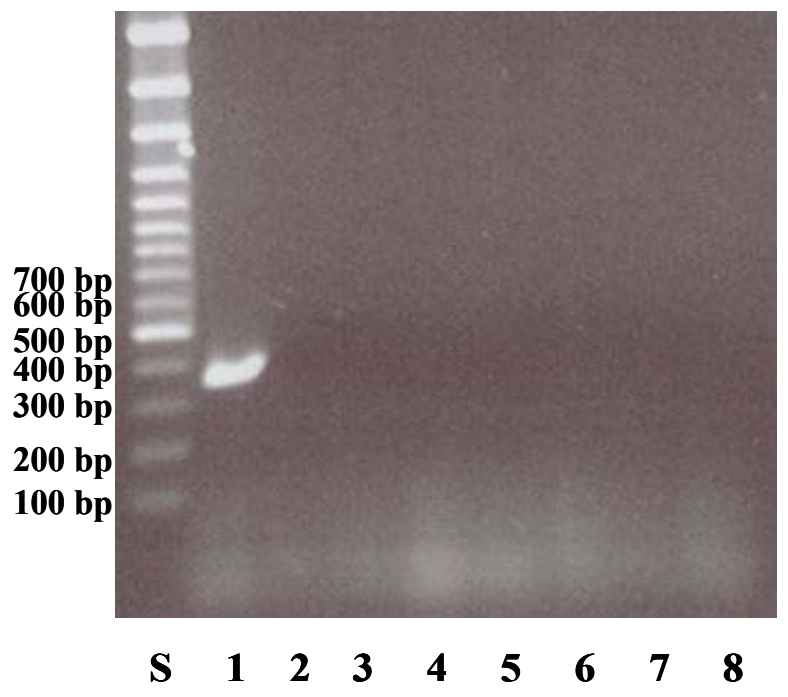

Abbildung 16: PCR der DNA Proben aus Meristemkartoffeln mit $\boldsymbol{H}$. solani spezifischen Primern (HSF120-HSR465). Die Amplifikation von Pflanzen-DNA durch $H$. solani spezifische Primer wurde ausgeschlossen. $\mathrm{S}=$ Standard DNA in $100 \mathrm{bp} \mathrm{Schritten;} 1=$ Positivkontrolle mit reiner $H$. solani DNA; 2 = Negativkontrolle ohne Matrizen-DNA; $3=$ Wurzelprobe von Karlena; $4=$ unterirdische Triebprobe von Karlena; $5=$ grüne Triebprobe von Karlena; $6=$ Wurzelprobe von Acapella; $7=$ unterirdische Triebprobe von Acapella; $8=$ Triebprobe von Acapella.

Die mit S bezeichneten Spuren zeigen die Standard DNA in 100 bp Schritten. Auf Bahn 1 wurde die Wasserkontrolle aufgetragen, auf Bahn 2 die Positivkontrolle mit H. solani DNA aus Sterilkultur gemischt. Bahnen 3-5 zeigen die PCR aus Wurzel, unterirdischem Trieb und grünem Trieb von Karlena, Bahnen 6-8 die aus Wurzel, 
unterirdischem Trieb und grünem Trieb von Acapella. In keiner Probe wurde DNA amplifiziert. Damit wurde gezeigt, dass pflanzliche DNA weder durch ITS noch durch H. solani spezifische Primer vervielfältigt wird. Anschließend wurden mit Silberschorf befallene Knollen der Sorten Karlena und Acapella gewaschen und die Oberflächen mit $70 \%$ Ethanol gereinigt. Danach wurden sie in steriler Erde ausgepflanzt und bis zur Abreife abgewartet. Die DNA aus Stolonen, Wurzeln und unterirdischen Trieben wurde extrahiert und eine nestedPCR mit ITS Primern und anschließend HSF120 - HSR 465 durchgeführt (Abb. 17). Die mit S bezeichneten Spuren zeigen die Standard DNA in 100 bp Schritten. Auf Bahn 1 ist die Positivkontrolle mit H. solani DNA aus Reinkulturen, auf Bahn 2 die Wasserkontrolle zu sehen. Auf Bahnen 3 -5 wurden die PCR Produkte mit DNA aus Trieb-, Wurzel-, Stolonproben der Sorte Acapella, auf Bahnen 6-8 die PCR Produkte mit DNA aus Trieb-, Wurzel-, Stolonproben der Sorte Karlena aufgetragen.

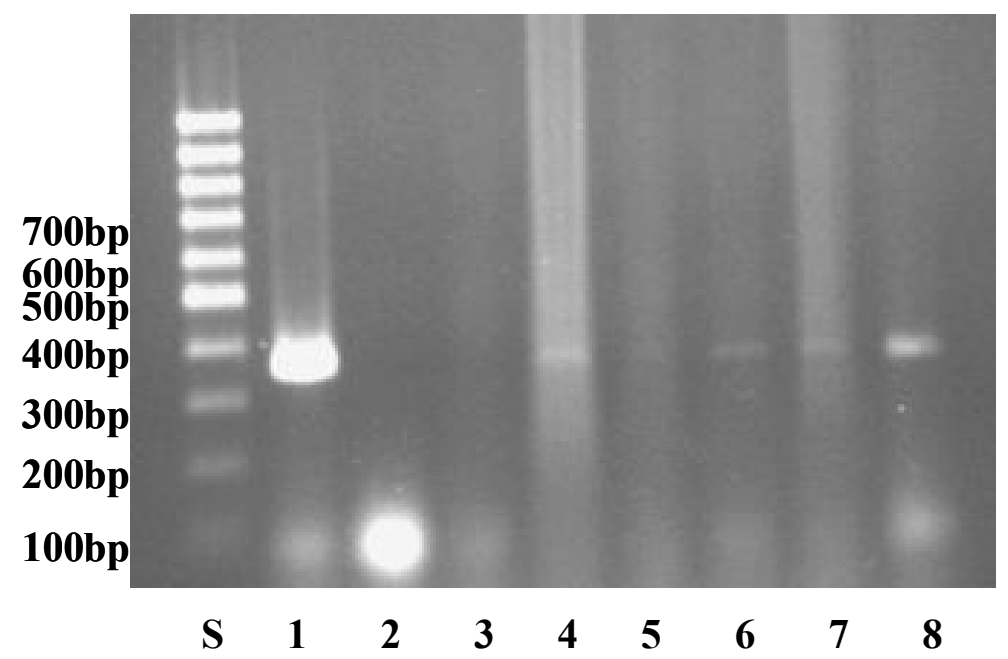

Abbildung 17: PCR der Stolonen, Wurzeln und Triebe verschiedener Kartoffelsorten mit H. solani spezifischen Primern (HSF120-HSR465). Der Pilz wurde in unterirdischen Pflanzenproben nachgewiesen. $\mathrm{S}=$ Standard DNA in $100 \mathrm{bp}$ Schritten; $1=$ Positivkontrolle mit reiner $H$. solani DNA; $2=$ Negativkontrolle ohne Matrizen-DNA; $3=$ PCR Produkt der Triebprobe von Acapella; $4=$ PCR Produkt der Wurzelprobe von Acapella; $5=$ PCR Produkt der Stolonprobe von Acapella; $6=$ PCR Produkt der Triebprobe von Karlena; $7=$ PCR Produkt der Wurzelprobe von Karlena; 8 = PCR Produkt der Stolonprobe von Karlena;

In der unterirdischen Triebprobe der Sorte Acapella wurde keine DNA von H. solani gefunden, aber in den Wurzeln sowie in den Stolonen wurde Silberschorf nachgewiesen. Bei der Sorte Karlena dagegen konnte in allen untersuchten Pflanzenteilen $H$. solani mittels PCR nachgewiesen werden. Der Versuch wurde mehrfach wiederholt mit ähnlichem Ergebnis. In Stolonen konnte der Pilz immer, in Wurzeln und unterirdischem Triebteil in ca. 60-70 \% der Fälle nachgewiesen werden. 
Damit wurde eine Übertragung von Silberschorf von Mutter- auf Tochterknolle über die Stolonen bestätigt. Die Tochterknollen der für diesen Versuch eingepflanzten Sorten wurden zur Bestätigung des Ergebnisses in Boxentests eingelagert und nach 8 Wochen auf Silberschorf bonitiert. Alle Knollen zeigten einen geringen bis mittelschweren Befall von 20-40 \% befallener Knollenoberfläche. Da die Knollenoberfläche sterilisiert und die Knollen in steriler Erde ausgepflanzt worden waren, bestätigt dies das durch die PCR gefundene Resultat. Um zu überprüfen, ob sich der Pilz systemisch in den Leitbündeln oder mit der Schale bzw. Rinde wächst, wurde abschließend noch nestedPCR mit Proben der Leitbündel aus befallenen Knollen der Sorten Karlena, Acapella und Arcula durchgeführt (Abbildung 18). Die mit S bezeichneten Spuren zeigen die Standard DNA in 100 bp Schritten. Bahn 1 zeigt eine Positivkontrolle in der DNA aus Knollenproben mit $H$. solani DNA aus Reinkultur gemischt wurde, um auszuschließen, dass die eventuell mit aufgereinigte Stärke der Knolle die PCR stört. Es konnte ein klares Signal in gewünschter Größe nachgewiesen werden, so dass eine Störung ausgeschlossen werden kann. Auf Bahn 2 ist die Wasserkontrolle aufgetragen. Auf Bahn 3 wurde die PCR der Leitbündel der Sorte Karlena, Bahn 4 der Sorte Acapella und Bahn 5 der Sorte Arcula aufgetragen. Es konnte in keiner Probe pilzliche DNA nachgewiesen werden. Auch in Wiederholungen wurde das Ergebnis bestätigt. Somit scheint sich der Pilz nicht systemisch sondern auf anderem Wege z.B. mit der Rinde ausbreiten.

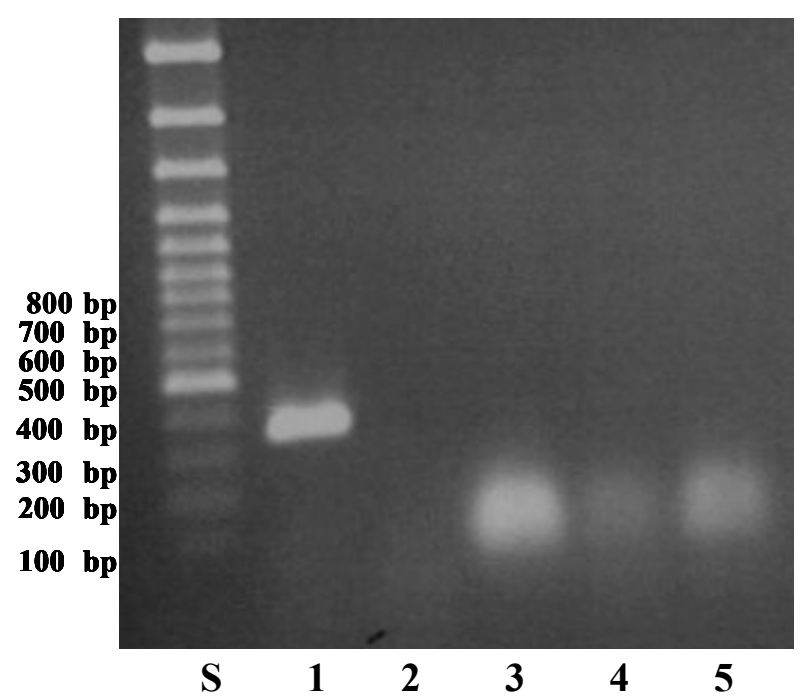

Abb. 18: PCR der Leitbündel der Sorten Karlena, Acapella und Arcula mit $\boldsymbol{H}$. solani spezifischen Primern (HSF120-HSR465). Der Pilz konnte nicht im Leitbündelsystem nachgewiesen werden. Bei den Signalen auf Bahnen 3-5 handelt es sich um Primerdimere. $\mathrm{S}=$ Standard DNA in 100 bp Schritten; 1=Positivkontrolle Knollen DNA gemischt mit $H$. solani DNA; 2=Negativkontrolle ohne Matrizen-DNA; 3=PCR Produkt der Leitbündel von Karlena; 4=PCR Produkt der Leitbündel von Acapella; 5=PCR Produkt der Leitbündel von Arcula; 


\section{Diskussion}

\section{Inokulumherstellung und Erstellung eines Standardsortiments}

Als erstes Ziel dieser Arbeit wurde die Erstellung eines Sortenspektrums mit klar abgrenzbarer Anfälligkeit angestrebt, um dieses als Vergleichsspektrum für spätere Resistenzzüchtung nutzen zu können. Der Einfluss äußerer Faktoren sollte überprüft werden. Um Versuche zur Befallsstärke verschiedener Kartoffelsorten gegenüber Silberschorf durchführen zu können, ist die Isolierung des Pilzes wie auch die Herstellung eines standardisierten Inokulums erforderlich. Daher erfolgte zunächst eine Optimierung der Inokulumherstellung. Die Isolierung des Pilzes ist auf Grund des langsamen Wachstums (ERRAMPALLI et al., 2001a) sehr schwierig. Die Isolierung von Kartoffelknollen wurde von GROTH \& WEBB (1983) beschrieben und in dieser Arbeit verwendet. Die Kontamination der Agarplatten durch andere Pilze war jedoch so hoch, dass dem Medium Bengal Rosa beigemischt wurde. Bengal Rosa bildet unter Lichteinfluss Sauerstoffradikale, die auf eine Vielzahl von Pilzen und Bakterien stark wachstumshemmend wirken (CHILVERS et al., 1999). Außerdem wurde dem Medium zur Vermeidung bakterieller Kontaminationen Streptomycin als bekanntes Breitbandantibiotikum zugesetzt. Dadurch konnte die Methode optimiert und vereinfacht werden.

Eine Isolierung aus Bodenproben stellt sich dagegen wesentlich schwieriger dar. $H$. solani zeigt im Vergleich zu anderen bodenbürtigen Pilzen auf Agarplatten ein sehr langsames Wachstum (ERRAMPALli et al., 2001a), und die Konidienkeimung wird offenbar von verschiedenen Böden unterdrückt. Dieser Punkt wird später noch ausführlich diskutiert. Eine Isolierung aus Bodenproben mit Selektivmedien scheint am einfachsten und daher sinnvollsten. Ein Selektivmedium zur Isolierung von $H$. solani wurde zwar von SINGH 1972 beschrieben, erwies sich in späteren Arbeiten jedoch als relativ unsensitiv und nicht zuverlässig in der Durchführung (CARNEGIE et al., 2003). Das in dieser Arbeit eingesetzte V8-Gemüsesaft Medium mit Zusatz von Streptomycin und Bengal Rosa erwies sich ebenfalls als nicht besonders effektiv, da trotz einer Vielzahl von eingesetzten Konidien die Anzahl der gekeimten Konidien äußerst gering war. Von Hall (1996) und CARnEgIE et al. (2003) wurde eine Bioassay Methode beschrieben, in der Miniknollen in infiziertem Boden ausgepflanzt werden. Danach konnte eine Bodeninfektion von $<10$ Konidien pro g Boden auf den Miniknollen 
nachgewiesen werden. Es fehlen jedoch Negativkontrollen der eingesetzten Knollen. Außerdem erfordert diese Methode einen enormen Zeit- und Materialaufwand und verursacht hohe Kosten. Zudem ist die Standardisierung der Methode schwierig. Das von LEDINGHAM \& CHINN (1955) beschriebene Flotationsverfahren zur Isolierung von Helminthosporium sativum aus Bodenproben wurde in dieser Arbeit für $H$. solani getestet. Dabei wird die Tatsache genutzt, dass die Konidien von $H$. sativum stark lipophil sind und sich somit in einer Ölsuspension gut von Bodenpartikeln trennen lassen. Leider zeigten sich die Konidien von $H$. solani als stark lipophob in allen getesteten Ölen, so dass diese Methode ungeeignet für $H$. solani ist. Es besteht also weiterhin Forschungsbedarf um eine geeignete, schnelle und kostengünstige Methode zur Isolierung von $H$. solani aus Bodenproben zu etablieren.

Der zweite wichtige Punkt zur Herstellung von Inokulum ist die Anzucht des Pilzes in vitro. Optimal wäre die Inokulumsanzucht in Flüssigmedium, um dieses direkt auf die Knollen übertragen zu können. Das inhomogene Wachstum des Pilzes wie auch die stark eingeschränkte Fähigkeit zur Konidienbildung, die schon von ELSON et al. (1998) beschrieben wurde, schließen dies jedoch aus. Daher wurde die Anzucht auf Agarmedium bevorzugt. Verschiedene frühere Studien zeigten, dass die Nährstoffversorgung im Medium einen signifikanten Einfluss auf die Konidienbildung von H. solani und dem Pilz ähnlichen Organismen hat (ELSON et al., 1998; COLEMAN \& Hodges, 1990; Evans \& BlaCK 1981; HARDING 1975). Es wurde gezeigt, dass ein zu hohes Kohlenstoff:Stickstoff Verhältnis bzw. nur ein hohes Kohlenstoffangebot im Medium die Konidienbildung unterdrückt. Die hohe Menge an Kohlenstoff im Kartoffeldextrosemedium, das ebenfalls von CARNEGIE et al. (2003) verwendet wurde, könnte daher die geringe Konidiendichte erklären. Auch das Angebot bestimmter Aminosäuren unterdrückt Wachstum und Konidienbildung des Pilzes (ELSON et al. 1998). Auf Kartoffelknollen wird die Entwicklung des Pilzes nach HeRviEUX et al. (2002) durch den Zusatz verschiedener organischer und anorganischer Salze unterdrückt. Dies könnte auch ein Grund für das schlechte Wachstum auf YEPD Medium sein, da es sich um ein mit Kohlenstoff, Aminosäuren und Salzen stark angereichertes Vollmedium handelt. Aminosäuren wie Leuzin, Tyrosin und Arginin als Stickstoffquelle förderten nach ELSON et al. (1998) dagegen das Wachstum und die Konidienbildung des Pilzes. Die exakte Kohlenstoff- und Stickstoff Zusammensetzung des V8-Gemüsesaftagars wurde nicht bestimmt, daher kann das verstärkte Vorhandensein dieser Aminosäuren nur vermutet werden. 1983 zeigten GROTH \& 
WeBB, dass V8-Agar sehr gut zur Anzucht von H. solani geeignet ist, jedoch ohne Erforschung der Ursachen oder Vergleiche zu anderen Medien. Auch MERIDA \& LORIA (1994b) beschrieben V8-Gemüsesaftagar als Konidienbildung förderndes Medium, ebenfalls ohne genauere Erforschung oder Vergleich zu anderen Medien. In dieser Arbeit wurden V8-Gemüsesaftagar als bestes Medium zur Anzucht von H. solani bestätigt im direkten Vergleich zu anderen Medien wie YEPD als Vollmedium oder Malzextraktagar und Kartoffel-Dextrose-Agar mit hohem Zuckerangebot.

Außerdem wurde der Einfluss von NUV-Bestrahlung auf Wachstum und Konidienentwicklung des Pilzes untersucht. Für Silberschorf wurden bisher nur Belichtungsversuche des Pilzes direkt auf Kartoffelknollenextrakten durchgeführt. Hier unterdrückte die Beleuchtung die Entwicklung des Pilzes deutlich (PERCIVAL et al., 1998). Dabei handelt es sich aber in erster Linie um die knollenspezifische Bildung von Glycoalkaloiden bei Belichtung (GRIFFITHS et al., 1994), welche die Entwicklung des Pathogens unterdrückt. In vitro liegen bisher keine Ergebnisse vor. In dieser Arbeit konnte aber kein Zusammenhang zwischen der Konidienbildung, Entwicklung von $H$. solani und der NUV - Bestrahlung gefunden werden.

Zur Dauerkultivierung von $H$. solani wurde Hafermehlagar in Schrägröhrchen verwendet, da von KAMARA \& Huguelet (1972) und MERIDA \& Loria (1994b) beobachtet wurde, dass der Pilz auf Haferblättern im Boden lange Zeit überleben kann. Zusammenfassend lässt sich für die Herstellung des Inokulums sagen, dass die Isolierung von Knollen erfolgreich optimiert wurde, während die Isolierung aus Bodenproben nach wie vor schwierig ist. Die Kultivierung des Pilzes geschieht am besten auf V8 - Gemüsesaft - Agar mit Beigabe von Bengal Rosa und Streptomycin als Schutz vor Kontaminanten. Eine Bestrahlung mit NUV-Licht scheint keinen Einfluss auf die Konidienbildung zu haben, die Inkubation kann im Dunkeln stattfinden.

Nach Herstellung des geeigneten Inokulums konnten die Versuche zur Befallsstärke verschiedener Kartoffelsorten gegenüber Silberschorf in Feld, Lager und Gewächshaus durchgeführt werden. In beiden Feldversuchsjahren zeigte sich, dass es keine vollkommen resistenten Solanum tuberosum - Sorten gibt, was schon von MERIDA et al. (1994) und Rodriguez (1995) vermutet wurde. Von Rodriguez et al. (1995) wurden allerdings verschiedene knollentragende Solanum spp., darunter Solanum demissum, beschrieben, die eine deutlich ausgeprägte Resistenz gegen $H$. solani ausbilden. Es ist bekannt, dass in wilden Solanum spp. Resistenzgene gegen fast alle wichtigen Kartoffelkrankheiten existieren (BAMBERG et al., 1994; ORTIZ, 1998; 
JANSKY, 2000). In späteren Arbeiten von JANSKY \& ROUSE (2003) wurde auch versucht, diese für verschiedene andere Knollenkrankheiten in interspezifischen Hybriden für die Züchtung nutzbar zu machen. Aus Kapazitäts- und Kostengründen konnten diese Wildtypen bzw. Hybridsorten in dieser Arbeit nicht mitgeführt werden, wären aber für zukünftige Arbeiten ein lohnender Ansatz.

Alle in dieser Arbeit getesteten Sorten wiesen im Feld, nach Lagerung und im Gewächshaus einen gewissen Silberschorfbefall auf, die Befallsstärke und die Symptomausprägung variierten aber in Abhängigkeit von der Sorte.

Ein Unterschied in der Resistenzausprägung verschiedener Solanum tuberosum - Sorten gegenüber $H$. solani wurde schon in früheren Studien erkannt (MERIDA und LORIA, 1994a; Hilton et al., 2000; StAchewicz et al., 2001). Obwohl in den Feldversuchen des ersten Jahres die einzelnen Standorte einen unterschiedlich hohen Infektionsdruck aufwiesen, veränderte sich die Befallsrangfolge der geprüften Sorten nur geringfügig. Im zweiten Versuchsjahr wurde eine Unterscheidung zwischen hohem und niedrigem Befallsdruck durch Inokulation der Hälfte der Parzellen simuliert. Auch hier veränderte sich die Befallsrangfolge kaum. Sorten wie Karlena und Secura waren immer anfällig, während Sorten wie Princess und Franzi sich immer als gering anfällig zeigten. Es konnte also das Ergebnis des Vorjahres bestätigt werden, dass die Sorten nach der Ernte eine ihnen eigene Anfälligkeit gegenüber $H$. solani zeigen, wodurch eine Differenzierung des Sortenspektrums möglich ist. Dabei existieren große Unterschiede zwischen den einzelnen Sorten, welche in ihrer Ausprägung zueinander unabhängig von äußeren Verhältnissen zu sein scheinen. Auch im Lager und Gewächshaus konnten diese Ergebnisse bestätigt werden. In früheren Arbeiten wurde postuliert, dass sich ein Pflanzgutvorbefall auf die Entwicklung von Silberschorf am Erntegut auswirken kann (READ \& HIDE, 1984; HIDE, 1987). Knollen mit starkem Vorbefall sollen demnach einen geringeren Befall am Erntegut bewirken, während Knollen mit niedrigem Vorbefall einen erhöhten Befall auslösen können. Begründet wird dies durch die Beobachtung, dass die Konidienkeimung auf großen, alten Läsionen stark limitiert ist, verglichen mit der von kleineren Läsionen (JELLIS \& TAYLOR, 1977; READ \& HIDE, 1984). Dies würde bedeuten, dass der Vorbefall maßgeblichen Einfluss auf die Sortenrangfolge in Bezug auf ihre Anfälligkeit hat. Optimal wäre das Einsetzen krankheitsfreien Pflanzgutes. Da aber auf Grund der stark gestiegenen Silberschorfproblematik kein sauberes Pflanzgut zur Verfügung stand, sollte diese Frage durch die Inokulation nur der Hälfte der Parzellen geklärt werden. Bei 
Vernachlässigung des jeweils im Boden vorhandenen Inokulums kann bei den unbehandelten Varianten von einem geringen Befallsdruck ausgegangen werden, da der Ausgangsbefall des Pflanzgutes sehr gering war. Durch Inokulation der anderen Parzellenhälfte waren diese Knollen einem hohen Befallsdruck ausgesetzt. Es ist aber auch möglich, dass auf Grund des im Sommer 2003 extrem heißen Wetters die Inokulation nicht erfolgreich angegangen war und somit ein Vergleich nur bedingt möglich ist. Anhand der Ernteergebnisse kann die in der Literatur beschriebene Umkehrung des Silberschorfbefalls in diesen Versuchen nicht bestätigt werden. An allen drei Standorten ergaben sich keine signifikanten Unterschiede zwischen unbehandelten und inokulierten Varianten, wobei ein Trend von stärkerem Befall bei inokulierten Varianten im Gegensatz zu unbehandelten Varianten zu erkennen war. Unterstützt wurde das Ergebnis aber auch durch sämtliche durchgeführten Lagerversuche, in denen der Ausgangsbefall der Knollen positiv korreliert mit dem Befall nach Lagerung. Da es in dieser Arbeit keine signifikanten Unterschiede im Sortenspektrum zwischen den verschiedenen Standorten und Jahren, sowie dem Gewächshausversuchen gab, kann daraus geschlossen werden, dass das Anfälligkeitsverhalten offenbar hauptsächlich sortenbedingt ist. Faktoren wie Witterung, Klima und Bodenverhältnisse wie auch Vorbefall scheinen für die Anfälligkeit kaum eine Rolle zu spielen.

Die Befallsstärke innerhalb eines Schlages scheint jedoch mit äußeren Bedingungen zu korrelieren, da an den unterschiedlichen Standorten der Gesamtbefall mit Silberschorf trotz einheitlichem Pflanzgut stark schwankte. Die Befallsrangfolge der einzelnen Sorten wird davon jedoch nicht beeinflusst. In der Literatur wird darauf hingewiesen, dass sich $H$. solani auf Sandböden besser entwickeln kann, als auf Lehm- oder Tonböden (LENNARD, 1980), während günstige Infektions- und Wachstumsbedingungen für den Pilz sortenunabhängig den Silberschorfbefall erhöhen (STACHEWICZ et al., 2001). Zudem haben die Vorfrüchte der vorausgegangenen Jahre sowie die Bodenbearbeitung offenbar einen Einfluss auf den Silberschorfbefall (CARTER et al., 2003; PETERs et al., 2003). Nach ADAMs et al. (1970) spielt auch die Nährstoffzusammensetzung wie z. B. Ammonium-, oder Stickstoffangebot sowie die Menge der im Boden vorhandenen Bakterien eine Rolle für die Entwicklung von Silberschorf. Ein großes Stickstoffangebot und die Anwesenheit vieler Bakterien verringern demnach deutlich den Befall mit Silberschorf. Von LEACH et al. (1991) wurde zudem ein Einfluss der eingesetzten Herbizide auf das Wachstum des Pilzes 
beschrieben. Welcher der Faktoren Boden, Klima, Witterung, bodenbürtiges Inokulum oder Bodenbehandlung während der Vegetationsperiode für die jeweilige Befallsstärke an den drei Standorten verantwortlich war, konnte nicht näher festgestellt werden.

Einen Einfluss auf den Silberschorfbefall kann auch der Befall mit C. coccodes haben, welcher im Rahmen dieser Arbeit ebenfalls bonitiert wurde. Bei C. coccodes, zuerst beschrieben 1926 von DiCKSON, handelt es sich ebenfalls um einen Schalenparasiten, der den selben Lebensraum wie Silberschorf einnimmt und dessen Symptome leicht mit denen des Silberschorfs verwechselt werden können (JELLIS \& TAYLOR, 1974; RADTKE et al., 2000; Lees \& Hilton, 2003). Da beide Pilze den gleichen Lebensraum beanspruchen, ist anzunehmen, dass sie in Konkurrenz zueinander stehen. Der Befall mit C. coccodes fiel an den drei Standorten und zwischen den Jahren sehr unterschiedlich aus. Weder eine sortenspezifische Resistenzentwicklung noch eine allgemeine Resistenz konnte in dieser Arbeit beobachtet werden. Aus der Literatur sind keine vollkommenen Resistenzen gegen den Pilz bekannt (LEES \& HiLTON, 2003). Verschiedene Arbeiten stellten Anfälligkeitsunterschiede bei unterschiedlichen Sorten fest (GANS et al. 2002; READ, 1991), wobei die Anfälligkeit auf Schalendicke (HUNGER \& MCInTYRe, 1979) bzw. Schalenfärbung (READ, 1991; Jellis \& TAYLOR, 1974) zurückgeführt wurde. Auch ein Zusammenhang zwischen dem Befall mit C. coccodes und mit Silberschorf im zweiten Versuchsjahr wurde nicht gefunden. Auf das Anfälligkeitspektrum der Knollen gegen Silberschorf hatte C. coccodes nach dieser Arbeit keinen erkennbaren Einfluss. In wieweit der Befall mit $C$. coccodes auf den standortspezifischen $H$. solani Befall dennoch einen Einfluss hat, kann jedoch nicht abschließend ausgeschlossen werden.

Bei Silberschorf handelt es sich um eine Krankheit, die sich hauptsächlich im Lager ausbreitet (PETERS, 1999). Dies konnte auch in den durchgeführten Lagerungsversuchen bestätigt werden, da sich die Befallsstärke bei allen Versuchen nach der Lagerung deutlich gesteigert hat. Daher ist die Erhebung der Lagerdaten von sehr großer Bedeutung. Auch im Lager zeigten die Sorten das gleiche Spektrum in Bezug auf ihre Anfälligkeit. Die nach der Ernte als stark anfällig deklarierten Sorten zeigten auch nach der Lagerung die stärksten Symptomausprägungen, während die als unempfindlich eingestuften Sorten auch nach der Lagerung geringen Silberschorfbefall zeigten. Es kann somit angenommen werden, dass die sortenspezifische Anfälligkeit von Anfang an direkt mit spezifischen Parametern der Knollenbeschaffenheit zusammenhängt, wobei äußere Umstände nur eine sehr geringe Rolle spielen. Die allgemeine Befallsstärke, dass 
heißt, der auf allen Sorten lastende Befallsdruck, kann dagegen stark durch die äußeren Umstände im Feld sowie vor allem im Lager beeinflusst werden (MERIDA et al., 1994; LENNARD, 1980). Nebenbei wurde im zweiten Jahr auch der Einfluss der Befallsstärke auf Pflanzenentwicklung und Ertrag ermittelt. Nach DENNER et al. (1997) kann der Pilz den Ertrag negativ beeinflussen, während Moor (1968) fand, dass die Krankheit zwar keinen Einfluss auf das Pflanzenwachstum, aber auf die Keimungsrate der Knollen hat. Im Wiederspruch dazu beobachteten READ \& HIDE (1984) einen negativen Einfluss von Silberschorf auf das Pflanzenwachstum, jedoch keinen auf den Ertrag. In den Untersuchungen dieser Arbeit konnte kein signifikanter Zusammenhang zwischen Pflanzenhöhe, Ertrag und Silberschorfbefall gefunden werden. Damit konnten keine der widersprüchlichen Ergebnisse der oben erwähnten Arbeitsgruppen bestätigt werden. Zusammenfassend zur ersten Zielsetzung dieses Projekts lässt sich sagen, dass ein geeignetes Spektrum von anfälligen bis hin zu wenig anfälligen Sorten erarbeitet werden konnte. Zudem konnte weitestgehend ausgeschlossen werden, dass äußere Verhältnisse sowie der Befall mit $C$. coccodes einen Einfluss auf das sortenspezifische Anfälligkeitsverhalten haben. Die Befallsstärke innerhalb eines Schlages oder Lagers dagegen ist deutlich von äußeren Einflüssen abhängig ohne die Befallsrangfolge der Sorten $\mathrm{zu}$ beeinflussen. Außer der Knolle scheinen nach dieser Arbeit auch keine anderen Pflanzenteil negativ durch den Befall mit Silberschorf beeinflusst zu werden. Aufbauend auf diesem Sortiment konnten nun genauere Laboruntersuchungen zur Ermittlung der Resistenzfaktoren und des Übertragungswegs unternommen werden.

\section{Resistenzfaktoren}

Nach Agrios (1978) gibt es verschiedene Wege, wie sich Pflanzen gegen Pathogene schützen können. Er unterteilt grob in eine strukturelle und eine biochemische Abwehr. Zunächst soll auf die strukturelle Abwehr eingegangen werden. Dabei lässt sich diese nach AgRIos (1978) wiederum in präformierte und induzierte strukturelle Abwehr gliedern. Bei der präformierten Abwehr handelt es sich um Strukturen, die schon vor dem Pathogenangriff vorhanden waren. Dazu gehören Strukturen wie Peridermdicke, Wachsschicht, Zellwandaufbau- und dicke, sowie Form und Anzahl der Lentizellen (AgRios, 1978; AKAI, 1959). 
In dieser Arbeit wurden als strukturelle präformierte Abwehr die Peridermdicke sowie deren Struktur untersucht. In früheren Arbeiten wurde angenommen, dass dünnschalige Sorten stärker anfällig gegen Silberschorf sind als dickschalige (HUNGER \& MCINTYRE, 1979) mit der Begründung, dass die Penetration dünnschaliger Sorten für den Pilz leichter sei. Ein Zusammenhang zwischen Schalendicke und Anfälligkeit konnte in dieser Arbeit aber nicht bestätigt werden, da keine statistisch signifikante Beziehung zwischen den beiden Parametern gefunden werden konnte. In verschiedenen mikroskopischen Arbeiten anderer Arbeitsgruppen wurde festgestellt, dass H. solani offenbar nur die Periderm- und Cortexschicht der Kartoffelknollen besiedelt (HEINY \& MCInTYRe, 1983; MARTINEZ et al., 2004). Dies spricht ebenfalls gegen die Annahme von Hunger \& MCInTyRe (1979), da somit eine dicke Periderm-Cortexschicht dem Pilz eine bessere Lebensgrundlage bieten würde. Danach kommt es bei der Penetration der Peridermschicht als Lebensgrundlage nicht auf die Dicke der gesamten Schale, wie von Hunger \& MCINTYRe (1979) angenommen, an, sondern auf die Dicke bzw. Zusammensetzung der einzelnen Zellwände der Peridermzellen (u.a. beschrieben von: Soliday et al., 1979; Cottle \& Kolattukudy, 1982; Heiny \& McIntyre, 1983; PuTZ, 1998). Bei den in dieser Arbeit gewonnenen Daten scheint aber wie erwähnt kein Zusammenhang zwischen Periderm-Cortex-Dicke und der Anfälligkeit zu bestehen. Bei näherer Betrachtung der Ergebnisse fällt die bei allen Sorten extrem hohe Standardabweichung auf. Da bei allen untersuchten Sorten die Probeknollen eine Streuung der Schalendicke von bis zu $2 \mathrm{~mm}$ aufwiesen, ließe dies den Schluss zu, dass die Periderm-Cortex-Dicke insgesamt kein geeignetes Kriterium zur Beschreibung einer Sorte darstellt. Vielmehr könnte dagegen die Peridermstruktur einen Einfluss auf die Anfälligkeit der Sorten haben. Einige der untersuchten Sorten wiesen dabei sortenbedingt eine glatte ungeschuppte Oberfläche auf, während andere zu starker Schuppenbildung neigten. Unter Umständen wäre es vorstellbar, dass dem Parasiten durch die schuppige Oberfläche mehr Angriffsfläche geboten wird und er dadurch einen stärkeren Befall verursachen kann. Diese Annahme wurde durch die in dieser Arbeit durchgeführten Wägetests überprüft. Es konnte jedoch ebenfalls kein signifikanter Zusammenhang zwischen Schalenstruktur und Anfälligkeit der Sorten ermittelt werden.

$\mathrm{Zu}$ den erst durch Pathogenangriff induzierten strukturellen Veränderungen gehören histologische Abwehrstrukturen, wie zum Beispiel die Ausbildung einer Korkschicht von Kartoffelknollen nach Verletzung oder Befall (RAMSEY, 1917), zelluläre Strukturen 
durch morphologische Veränderungen der Zellwand (MARTIN, 1964, HARDHAM \& Mitchell, 1998), zytoplasmatische Abwehrreaktionen (AGRIOS, 1978) sowie die nekrotische Abwehrreaktion durch Hypersensitivität (MULLER, 1959).

Um die induzierten strukturellen Abwehrmechanismen $\mathrm{zu}$ untersuchen, wurden im Rahmen dieser Arbeit lichtmikroskopische Versuche angestrengt. Dabei sollte auch geprüft werden, wie und wieweit der Pilz in das Gewebe der Knollen eindringt. Dafür wurde zunächst eine geeignete Färbemethode des Pilzes in Knollengewebe gesucht. In der Arbeit von Heiny \& MCInTYRe (1983) wurde zum Anfärben des Pilzes für die Lichtmikroskopie auf Knollenoberflächen Lactophenol Baumwoll Blau verwendet. Durch Verwendung von Calcofluor (RoHRINGER, 1977) in dieser Arbeit konnte eine stark vereinfachte Methode zur Anfärbung des Pilzes auf Knollenoberflächen dargestellt werden. Zur Färbung des Pilzes in Knollenquerschnitten wurden bei HEINY \& MCInTYRe (1983) Ammoniacal Gentian Violet (ArTschwager, 1927), Pianese IIIb (Simmons \& SHOEMAKER, 1952), Stoughton's Thionin und Orange G (Clark, 1973) sowie Safranin-fast Green (JoHANSEN, 1940) eingesetzt. Dabei handelt es sich um alte, sehr komplizierte Färbeverfahren, die durch diese Arbeit nach Möglichkeit verbessert werden sollten. Leider konnte jedoch keine geeignetere Färbemethode zur Hervorhebung des Pilzes in Knollenquerschnitten gefunden werden. HEINY \& MCINTYRE (1983) und MARTINEZ et al. (2004) untersuchten die Knollenproben auch mit Hilfe der Transmissions- und Raster-Elektronenmikroskopie. Dies konnte aus Zeitund Kapazitätsgründen in dieser Arbeit nicht durchgeführt werden. Eine Erforschung der Penetration sowie Ausbreitung im Gewebe konnte daher nicht weiterverfolgt werden. Nach den Publikationen von Heiny \& MCInTYRe (1983) und MartinEZ et al. (2004), konnte der Pilz aber ausschließlich in der Periderm-Cortexschicht der Knollen nachgewiesen werden. Danach penetriert der Pilz das Periderm 6-9 Stunden nach Inokulation. Während HEINY \& MCINTYRE (1983) und BURKE (1938) appressorienartige Gebilde beobachteten, konnte MARTINEZ et al. (2004) diese nicht nachweisen. Diese gehen sowohl von einem mechanischen als auch enzymatischen Prozess der Penetration aus (HARdHAM \& Mitchell, 1998). Anschließend wächst der Pilz intrazellulär in das Periderm und die Cortexschicht ein, wobei er eine Nekrose in den betroffenen Zellen auslöst (MIMS, 1991). Interessant ist, dass MARTINEZ et al. (2004) zeigten, dass nicht nur die befallenen Zellen Zeichen einer Nekrose aufwiesen, sondern auch die darum liegenden gesunden Pflanzenzellen. Ob es sich dabei um einen Versuch der Abwehr der Pflanze handelt (Muller, 1959) oder ob H. solani sich 
nekrotroph ernährt (MIMS et al., 2000) und somit den Zelltot bewirkt, ist unklar. Andere induzierte strukturelle Abwehrmechanismen der Pflanze wurden nicht beobachtet, wobei MARTINEZ et al. (2004) vermutet, dass der Pilz Abwehrmechanismen der Pflanze vor Penetration der Zellwand unterdrückt. Dies wurde z.B. auch während Infektion von Gerste mit Erysiphe graminis, Kartoffeln mit Phytophtora infestans oder Bohnen mit Uromyces vignae beobachtet (BUSHNELl \& BERGQUIST, 1975; TOMIYAMA, 1956; XU \& MENDGEN, 1991).

Anschließend zur strukturellen Abwehr der Pflanzen soll auf die biochemische Abwehr der Knollen eingegangen werden. Nach AGRIOS (1978) fällt der biochemischen Abwehr die weitaus größere Bedeutung im Vergleich zur strukturellen Abwehr zu. Auch hier lässt sich wiederum in präformierte und induzierte biochemische Abwehr unterteilen (AgRIOS, 1978). Zu den präformierten biochemischen Antworten der Pflanze gehört die generelle Abgabe inhibitorischer Substanzen an die Umwelt oder ihr Vorhandensein direkt in der Pflanzenzelle (AKAi \& OUCHI, 1971; Deverall, 1977; Agrios, 1978). Auch die ständige Abwesenheit bestimmter Nährstoffe kann zur Resistenz der Pflanzen gegen obligat parasitische Pilze führen (BATEMAN, 1967).

In dieser Arbeit wurde als präformierter biochemischer Abwehrmechanismus der Gesamtgehalt phenolischer Substanzen gemessen. Den phenolischen Substanzen einer Pflanzenzelle werden in vielfacher Hinsicht antiphytopathogene Wirkungen nachgesagt (NiCHOLSON \& HAMMERSCHMIDT, 1992). Zum einen dem Suberin, welches bei vielen Pflanzen in Verbindung mit der Wachsschicht die Kutikula der Peridermzellen ausmacht und Wasser- sowie Nährstoffverlust verhindert (ESAU, 1977; KOLATTUKUDY, 1981; CotTle \& KolatTuKudy, 1982). Zum anderen dem Lignin (MOERSCHBACHER et al. 1988; Southerton \& Deverall, 1990a, 1990c) und dessen Vorstufen Ferulasäure und p-Cumarsäure (SOUTHERTON \& DeVERALl, 1990b; Sun, 2001), die in Zusammenhang mit Resistenzen des Weizens gegenüber verschiedenen Pathogenen gesehen werden (SANDER, 1992; MENDEN, 1995). Lignin und dessen Vorstufen pCumarsäure und Ferulasäure können nach SANDER (1992) mit weiteren phenolischen Substanzen der Zelle stark verzweigte, dreidimensionale Netzstrukturen bilden. Die hohe Anzahl freier Seitenketten in dieser Struktur ermöglicht dem Lignin viele Verknüpfungen mit anderen Zellwandkomponenten, was eine große Bedeutung für die Stabilität der Zellwand hat (SARKANEN \& LudwIG, 1971). SANDER (1992) nimmt an, dass durch Verschiebung der Zellwandmikrofibrillen bei Penetration der Zelle durch ein 
Pathogen (NEMEC, 1971) die entgegenwirkende Vernetzung der Zellwandkomponenten mit den Ligninkomplexen die Druck- und Zugfestigkeit der Epidermiszellwand erhöht (FRY, 1982). Dadurch soll die weitere Penetration des Pilzes erschwert werden (RIDE, 1980; FRIEND, 1981). Zudem wird ein erschwertes Eindringen pilzlicher Cellulasen in die Pflanzenzelle durch somit verringerten Durchmesser der Zellwandporen angenommen (SANDER, 1992). Von MARTINEZ et al. (2004) konnten jedoch elektronenmikroskopisch keine Verdickungen der Zellwände von Kartoffeln nach Penetration durch $H$. solani beobachtet werden.

Der Gesamtgehalt phenolischer Verbindungen in den Kartoffelschalen der zwölf untersuchten Sorten war sehr unterschiedlich, zeigte aber keine signifikante Beziehung zur Anfälligkeit. Interessant ist die genaue Zusammensetzung der phenolischen Komponenten. Daher sollte eine qualitative Analyse der Verbindungen erfolgen. Suberine werden hauptsächlich bei Verletzungen der Knolle zum Schutz gegen Wasserverlust gebildet (BernARDS et al., 1999; CotTle \& KOlATTUKUdy, 1982; Clarkson, 1974) und spielen so nur eine indirekte Rolle in der Pathogenabwehr. Auf Grund dessen wurde das Augenmerk somit hierbei auf die Lignine und dessen Vorstufen gelegt. Die Aufreinigung sowie die anschließende HPLC der phenolischen Verbindungen erfolgte in Anlehnung an SANDER (1992). Dabei wurde mit dem Prinzip der alkalischen Hydrolyse gearbeitet (MORTIMER, 1987), welches zur Aufreinigung von phenolischen Verbindungen aus Weizenblättern geeignet ist (SANDER, 1992). Da keine der gesuchten Standardsubstanzen in den aufgereinigten Proben gefunden werden konnte, muss angenommen werden, dass diese Methode nicht geeignet ist, Lignine und andere phenolische Verbindungen aus Kartoffelschalen zu lösen. Bei der Umsetzung aufgereinigter Zellwände mit Thioglycolsäure, wie bei der Gesamtbestimmung von phenolischen Verbindungen durchgeführt, bilden sich alkalilösliche, säureunlösliche Phenolthioglycolsäurekomplexe (MENDEN, 1995). Da die HPLC auf Methanol und Ameisensäure optimiert wurde, ist diese Aufreinigungsmethode hier nicht anwendbar. In der Literatur sind verschiedene weitere Aufreinigungsmethoden beschrieben, die jedoch für die Analyse von Ligninen aus Kartoffelschalen optimiert werden müssten. Die vielversprechendsten sollen kurz dargestellt werden. Nach COTTLE \& KOLATTUKUDY (1982) erfolgt die Aufreinigung phenolischer Verbindungen aus Kartoffeln durch alkalische Nitrobenzen - Oxidation (STONE \& BLundeLL, 1951) und anschließender Integrierung von radioaktivem Phenylalanin und Zimtsäure zur Analyse in Radio-Gas Chromatographie und Massenspektroskopie. Dabei wurden allerdings 
nicht die in der Schale vorhandenen Lignine, sondern die phenolischen Suberine untersucht. Sun et al. (2001) beschrieben eine neue Methode zur quantitativen Analyse von Lignin gekoppelten Phenolsäuren in unterschiedlichen Pflanzen (ohne Kartoffeln), wobei die Methode ebenfalls auf dem Prinzip der alkalischen Hydrolyse beruht. Diese schien aber schon nach der Methode von SANDER (1992) für Kartoffelschalen nicht geeignet. SOBOLEV (2001) extrahierte Vanillin durch Acetonitril aus gekochten Erdnüssen mit anschließender HPLC. Dabei wurde jedoch keine andere phenolische Substanz mit erfasst, was für die qualitative Analyse phenolsicher Substanzen in Kartoffelschalen nicht ausreichend ist. Eine weitere Möglichkeit zur Ligninanalyse beschreiben PENG et al. (1998) durch Verwendung der von LU \& RALPH (1997a,b; 1998) beschriebenen „derivatization followed by reductive cleavage“ (DFRC) Aufreinigungsmethode und anschließender Gel Permeations Chromatographie, RP (,reversed - phase“)-TLC ("thin layer chromatography”) und HPLC. Dabei wurde der Ligningehalt in Pinus taeda L. untersucht. Bei der DFRC Methode (LU \& RALPH 1997a, b; 1998) handelt es sich um eine komplizierte chemische Prozedur, welche die Möglichkeiten dieser Arbeit überschritten. Die DFRC - Methode scheint jedoch für zukünftige Arbeiten die vielversprechendste Methode zur Untersuchung von Ligninen in Kartoffelschalen zu sein.

Wie erwähnt kann auch die Abwesenheit bestimmter Nährstoffe nach BATEMAN (1967) einen Schutz gegen Parasiten darstellen. Die Suppressivität verschiedener Böden auf die Keimung von $H$. solani Konidien wurde im Rahmen dieser Arbeit untersucht. Alle geprüften Böden zeigten eine starke Suppressivität. Es wurde aber in späteren Tests festgestellt, dass die Anwesenheit bestimmter Kartoffelsorten diese Suppressivität teilweise wieder aufhebt. Diese Eigenschaft steht in stark signifikanter Beziehung zur Anfälligkeit der Sorten gegen Silberschorf. MARTINEZ et al. (2004) beobachteten, dass Konidien von $H$. solani auf Kartoffeloberflächen schneller keimen als auf Nährmedium. Sie vermuten eine Stimulation der Keimung durch die Knollen. Für diese Stimulation können verschiedene Ursachen verantwortlich sein. Unter Umständen handelt es sich hierbei um eine präformierte biochemische Abwehr. Es könnten verschiedene essentielle Nährstoffe von anfälligen Knollen in die Umgebung abgegeben werden, welche die Konidien zur Keimung benötigen. Die Suppressivität von Böden lässt sich durch verschiedene Hypothesen erklären (DE BOER et al., 2003); zum einen die „nutrient deprivation hypothesis“ in der die Keimhemmung auf Grund des limitierten Kohlenstoffangebots im Boden durch Nahrungskonkurrenz mit anderen 
Mikroorganismen erklärt wird (Ho \& Ko, 1986; LOCKWOOD,1977). Daher hebt die Zugabe von Zucker die Bodensuppressivität teilweise wieder auf (LOCKWOOD, 1977). Es wurde daher untersucht, ob Knollen verschiedener Sorten unter Umständen unterschiedliche Mengen an Kohlenstoff in Form von Zuckerderivaten wie Glucose, Fructose oder Saccharose in die Umgebung abgeben und somit die Keimung von $H$. solani wiederum fördern. Es konnten jedoch kaum gesteigerte Mengen der untersuchten Zucker gefunden werden, welche auch in keiner signifikanten Beziehung zur Anfälligkeit der Sorten standen. Es kann vermutet werden, dass die Knollen Kohlenstoff bzw. Stickstoff in anderer Form, z.B. als Aminosäuren in die Umgebung abgeben. Auch dies kann nach LOCKWOOD (1977) zur Keimförderung führen. Wie anfangs beschrieben förderten nach ELSON et al. (1998) Aminosäuren wie Leucin, Tyrosin und Arginin als Nahrungsquelle das Wachstum des Pilzes.

Eine weitere Hypothese zur Erklärung der Bodensuppressivität ist die Anwesenheit verschiedener fungistatischer Substanzen mikrobiellen (BURGESS et al.,1999; LIEBMAN \& EPSTEIN, 1992) oder pflanzlichen (BASHA, 2002; MAURYA, 2002) Ursprungs. Es wäre möglich, dass anfällige Knollen Substanzen in ihre Umgebung abgeben, die diese fungistatische Keimhemmung wiederum aufheben. Um welche Substanzen es sich dabei handeln könnte, ist unklar. Dafür müsste zunächst die antibiotische Substanz gefunden werden, welche die Keimhemmung auslöst. Anschließend könnte die von der Knolle produzierte keimfördernde Substanz durch Screeningversuche ermittelt werden.

Zur induzierten biochemischen Abwehr gehört eine große Palette chemischer Abwehrantworten der Pflanze gegen Pathogene (AgRIos, 1978). Die phenolischen Substanzen spielen auch hier ein große Rolle (FARKAS \& KIRÁLY, 1962). Die oben diskutierte Lignifizierung der Zellen kann neben der präinfektionellen Bildung bei verschiedenen Pflanzen auch durch mechanische Verletzung (GRISEBACH, 1981; HiguchI, 1985) oder Pathogenbefall induziert werden (RIDE \& PEARCE, 1979; RIDE, 1980). Daher wurden neben den erkrankten Pflanzenproben immer Gesundkontrollen mitgeführt, um einen möglichen Anstieg der phenolischen Zellkomponenten zu detektieren. Wie beschrieben, konnte für Kartoffelschalen noch keine geeignete Aufreinigungsmethode zur qualitativen Analyse der phenolischen Zellwandkomponenten gefunden werden. Es sollten daher jedoch in Zukunft aus den genannten Gründen immer Gesundkontrollen mitgeführt werden, damit zwischen präformierter und induzierter biochemischer Abwehr unterschieden werden kann. 
Eine weitere wichtige induzierte biochemische Abwehr ist die Bildung von Phytoalexinen (AgRIOS, 1978). Phytoalexine sind eine chemisch heterogene Gruppe von niedermolekularen Substanzen mit antimikrobiellen Eigenschaften (HALVERSON \& StACEY, 1986), die von Pflanzen als Antwort auf Infektion oder Stress gebildet werden (KUĆ, 1995). In gesunden Pflanzen sind sie nicht vorhanden, werden aber in vielen Fällen durch Befall mit Pathogenen freigesetzt (BELL et al, 1984). Dabei wird eine Komponente des Pathogens (Elicitor) von der Pflanzenzelle erkannt, was zur Produktion der Phytoalexine führt (HALVERSON \& StACEY, 1986). Dies kann systemisch in der Pflanze übertragen werden, wobei Hydroxybenzoesäure, besser bekannt als Salizylsäure (HART, 1989), als Signaltransduktor fungiert (FAIZE et al., 2004). Hydroxybenzoesäure wurde im Rahmen der HPLC - Erfassung phenolischer Zellkomponenten mit untersucht, was aus diesem Grund auch in zukünftigen Arbeiten beachtet werden sollte. Eine Erhöhung der Hydroxybenzoesäure Konzentration in der erkrankten Zelle könnte auf verstärkte Akkumulation von Phytoalexinen und systemische Übertragung der Abwehr in der Knolle hinweisen. Die bisher in der Kartoffel gefundenen Phytoalexine sind Sesquiterpenoide (KUĆ, 1973), nämlich Rishitin (TOMiYAma et al., 1968), Lubimin (METLITSKi et al., 1979), Phytuberin (VARNS et al., 1971) und Solavetivone (COXON et al., 1974). Diese wurden hauptsächlich als Abwehrstoffe gegen den Erreger der Kraut- und Knollenfäule, Phytophthora infestans, gefunden (HAMMERSCHMIDT, 1999). Das Vorhandensein von Phytoalexinen in der Schale wurde in gesunden und auch in erkrankten Pflanzenproben untersucht. Für die Gesamtheit der in Kartoffeln gebildeten Sesquiterpenoide (KUĆ, 1973) konnte keine geeignete Aufreinigungs- und Trennungsmethode gefunden werden. Daher wurde eine von SAKAI et al. (1979) beschriebene Methode zur Aufreinigung von Rishitin aus Kartoffelknollen für Dünnschichtchromatographie mit Cyclohexan/Ethylacetat (1:1) als Laufmittel angewendet. Sowohl in der Dünnschichtchromatographie als auch im Bioassay wurden in kranken wie auch gesunden Proben der Sorten Bernadette und Marabel Substanzen gefunden, die das Pilzwachstum hemmen. Zum einen könnte dies darauf hinweisen, dass die gefundenen Substanzen schon vor Pilzbefall gebildet wurden und somit eine präformierte Abwehr der entsprechenden Sorten darstellt. Da jedoch auf Grund der stark gestiegenen Silberschorfproblematik in Deutschland (STECK \& ZELLNER, 2002) keine Knollen ohne jeglichen Befall erhältlich sind, waren auch die Knollen der Gesundproben an anderen Stellen leicht mit $H$. solani befallen. Die Proben wurden daher an eindeutig gesunden 
Teilen der Knolle entnommen. Da sich die induzierte biochemische Abwehr durch Bildung von Phytoalexinen jedoch systemisch ausbreiten kann (RYALS et al., 1996; KUĆ, 1995), könnte somit auch in den noch nicht befallenen Pflanzenteilen die Akkumulation von Phytoalexinen begonnen haben. Als Negativkontrollen sollten daher in Zukunft immer eindeutig gesunde, in vitro gezogene Knollen von Meristemkartoffeln dienen. Ein weiteres Problem war die Durchführung des Bioassays mit H. solani. Der Pilz zeigt in Nährmedium ein extrem langsames Wachstum (MERIDA \& LORIA, 1994b) und wird im Bioassay innerhalb von 2 Tagen von Kontaminanten überwachsen. Daher musste auf den schnellwüchsigen Cladosporium spp. zurückgegriffen werden. $\mathrm{Ob}$ die gefundenen Substanzen auch das Wachstum von H. solani unterdrücken, kann somit nur vermutet werden. Die Anfälligkeit der Sorten Bernadette und Marabel liegt in allen Screeningversuchen im mittleren Bereich des Sortenspektrums, so dass hier keine signifikante Beziehung zwischen den beiden Parametern besteht. Trotzdem wurde versucht, in anschließender HPLC mögliche Phytoalexine qualitativ nachzuweisen. Als Laufmittel wurden Wasser und das von SAKAI et al. (1979) für Dünnschichtchromatographie empfohlene Cyclohexan/Ethylacetat Gemisch (1:1) verwendet, der Gradient wurde aus einer für Phytoalexine aus Raps optimierten HPLC übernommen (KoOPMANN, 2004). Die in Raps gebildeten Phytoalexine gehören der Gruppe der Indolderivate an (GROSS, 1993), die mit den Sesquiterpenoiden verwandt sind (TARCHEVSKY, 2001). Es wurde angenommen, dass die Sesquiterpenoide ebenfalls mit dieser Methode erfassbar sind. Es konnten in den untersuchten Proben aber keine der bekannten Phytoalexine nachgewiesen werden. Ob alle Phytoalexine der Kartoffel aber tatsächlich mit der Methode nach SAKAI (1979) extrahiert und in der HPLC gemessen werden konnten, ist unklar. Da jedoch alle Untersuchungen in Bezug auf Phytoalexine als Antwort auf Silberschorfbefall darauf hinwiesen, dass kein Zusammenhang besteht, wurde die Frage nach den Phytoalexinen nicht weiter verfolgt.

Zusammenfassend lässt sich sagen, dass nach den Ergebnissen dieser Arbeit strukturelle Abwehrmechanismen eine untergeordnete Rolle in der Abwehr gegen H. solani spielen. Dagegen scheint der biochemischen Abwehr die größere Bedeutung zuzukommen. Offenbar geben die Knollen verschiedener Sorten unterschiedliche Mengen einer Substanz in ihre Umgebung ab, welche die Keimung von $H$. solani Konidien fördert. Um welche Substanzen es sich dabei handelt, ist unklar. Ein erhöhtes Kohlenstoffangebot in Form von Zuckern scheint nicht die Ursache zu sein. Dies ist ein 
interessanter Ansatzpunkt für weiterführende Untersuchungen. Die Bildung von Phytoalexinen scheint ebenfalls in keinem Zusammenhang mit der Abwehr gegen Silberschorf $\mathrm{zu}$ stehen, soweit die durchgeführten Untersuchungen diese Annahme zulassen. In wieweit Lignifizierung der Zellwände sowie die Einlagerung von Phenolen eine Rolle in der biochemischen Abwehr spielt, konnte in dieser Arbeit nicht abschließend geklärt werden, wobei in der Literatur diesen Mechanismen auch keine große Bedeutung bei der Interaktion zwischen Kartoffeln und $H$. solani zugeschrieben wird (MARTINEZ et al., 2004). Dennoch besteht auch hier weiterer Forschungsbedarf.

\section{3 Übertragungsweg des Pilzes von Mutter- auf Tochterknollen}

Wichtig zum Verständnis des Lebenszyklus und damit möglichen Schwachstellen des Pilzes ist die Kenntnis über den Übertragungsweg von $H$. solani im Boden von Mutterauf Tochterknollen. Die Pflanzknolle wurde von BURKE schon 1938 als entscheidende Inokulumquelle bezeichnet. Im Boden kann der Pilz auch eine noch ungewisse Zeit überleben (KAMARA \& Huguelet, 1972; MERIDA \& LORIA, 1994b) wird aber nach Hunger \& MCINTYRe (1979) erst durch befallenes Pflanzgut in den Boden gebracht. Ein bodenbürtiges Vorkommen wird durch die in dieser Arbeit festgestellte starke Suppressivität verschiedenster Böden auf die Keimung von $H$. solani Konidien erschwert. Der genaue Übertragungsweg ist noch unbekannt (RoDRIGUEZ et al., 1996). Silberschorfsymptome zeigen sich ausschließlich auf den Kartoffelknollen, nicht jedoch auf den Stolonen und anderen unterirdischen wie oberirdischen Pflanzenteilen (ERRAMPALLI et al., 2001a). Bisher wurde angenommen, dass die Infektionsübertragung durch direkten Kontakt der Mutter- mit den Tochterknollen erfolgt, bzw. durch Übertragung mittels Bodenwasser bei räumlicher Nähe von Mutter- und Tochterknollen (FrAZIER et al., 1998). HIDE \& ADAMS (1980) beschrieben einen verstärkten Augenbefall der Mutterknollen während JELLIS \& TAYLOR (1977) sowie FIREMAN \& ALLEN (1995) zeigten, dass die Erstinfektion der Tochterknollen schon kurz nach der Entwicklung auftreten können und dabei oft am Stolonenende der Knolle lokalisiert ist. HIDE (1987) beschrieb eine schlechtere Übertragung von Silberschorf in stark bewässerten Böden. FIREMAN \& ALLEN (1995) nehmen an, dass das Wasser an den Stolonen entlang $\mathrm{zu}$ den Tochterknollen geleitet wird, wobei sie eine stark eingeschränkte Überlebensfähigkeit der Konidien im Boden feststellten. In dieser Arbeit 
wurde beobachtet, dass die meisten Stolonen nicht direkt an der Mutterknolle gebildet werden, sondern erst aus dem unterirdischen Teil der Triebe entstehen. Dies erschwert einen Wassertransport entlang der Stolonen. Zudem kann die Bodendynamik in verschiedenen Böden durch deren Zusammensetzung sehr unterschiedlich sein, was die Fließeigenschaften von Wasser stark beeinflusst. Dies alles lässt vermuten, dass $H$. solani womöglich nicht nur durch passiven Transport der Konidien im Boden übertragen wird, sondern auch in der Lage sein könnte, aktiv mit den Stolonen von Mutterknolle zu Tochterknolle zu wachsen.

Zunächst wurde die passive Übertragung mit Wasser über den Boden in speziell dafür konstruierten Pflanzrinnen überprüft. Es wurde festgestellt, dass nur sehr wenige Konidien mit dem Bodenwasser transportiert wurden. Dabei wurden auch Konidien in den Pflanzrinnen mit nicht inokulierten Pflanzknollen gefunden. Dies liegt wahrscheinlich hauptsächlich daran, dass das Pflanzgut nicht völlig befallsfrei war. Nach FiREMAN \& ALLEN (1995) entwickeln sich im Boden auf befallenen Mutterknollen relativ große Mengen an Konidien, die dann ebenfalls mit dem Wasser transportiert werden können. Es wurde, wie oben diskutiert, in Bodensuppressivitätstests ermittelt, dass Böden unterschiedlichster Herkunft eine suppressive Wirkung auf die Keimung von H. solani haben. Diese Suppressivität kann nach PETERS et al. (2003) sogar durch bestimmte Bodenbearbeitung und Fruchtfolgen verstärkt werden. Zusammenfassend zu den Untersuchungen der passiven Übertragung von $H$. solani mittels Bodenwasser von Mutter- auf Tochterknollen scheint diese, nach dieser Arbeit, nur eine untergeordnete Rolle zu spielen.

Um die aktive Übertragung des Pilzes durch Mitwachsen in den Stolonen zu überprüfen, wurden PCR Analysen mit $H$. solani spezifischen Primern an den unterirdischen Teilen von Kartoffelpflanzen durchgeführt. Dafür wurde ein Verfahren zur Detektion von Silberschorf aus Boden und Pflanzenproben nach OLIVIER \& LORIA (1998) modifiziert. ERRAMPALLI et al. (2001b) wiederholte die Methode mit anderen $H$. solani Primerpaaren. Da die PCR-Methode von OLIVIER \& LORIA (1998) aber in Vorversuchen sehr gute Ergebnisse brachten, wurden sie beibehalten. Als Positivkontrolle konnte Silberschorf erfolgreich in befallenen Schalenproben nachgewiesen werden. Auch die Technik der nestedPCR war erfolgreich. Bei der Überprüfung der Stolonen konnte in allen untersuchten Proben tatsächlich $H$. solani DNA nachgewiesen werden. Auch in Wurzeln sowie im unterirdischen Triebteil wurde pilzliche DNA bei einigen Proben nachgewiesen. In Negativkontrollen von Wurzel- und 
Triebproben gesunder Meristempflanzen konnte der Pilz dagegen nie festgestellt werden. Dies alles weist darauf hin, dass der Pilz tatsächlich doch in der Lage ist, mit der Pflanze in die Tochterknolle einzuwachsen. Dies wirft die Frage auf, ob der Pilz sich systemisch, also über das Leitbündelsystem (BÖNER, 1997) ausbreitet oder anders, vielleicht mit der Epidermis der Stolonen, mitwächst. Daher wurden PCR Versuche mit Leitbündelproben befallener Knollen durchgeführt. Auch mit der nestedPCR konnte keine pilzliche DNA nachgewiesen werden. Es wird daher angenommen, dass die Ausbreitung des Pilzes nicht systemisch ist. Dies wird auch durch die mikroskopischen Untersuchungen von MARTINEZ et al. (2004) und HeINY \& MCINTYRE (1983) unterstützt, die keine pilzliche Strukturen unterhalb der Periderm-Cortex - Schicht feststellen konnten. Damit scheint die Übertragung von Mutter- auf Tochterknollen tatsächlich aktiv über die Stolonen möglich zu sein und im Vergleich zur passiven Übertragung mittels Bodenwasser unter Umständen die größere Bedeutung zu haben. In zukünftigen Untersuchungen sollte geprüft werden, in welchem Teil des Stolons der Pilz mitwächst. Außerdem wäre interessant zu ermitteln, ob es Unterschiede in der aktiven Übertragung zwischen anfälligen und wenig anfälligen Sorten gibt.

Zusammenfassend und abschließend soll versucht werden, einen möglichen Lebenszyklus von H. solani zu konstruieren (Abb.17). Hauptinokulum ist das befallene Pflanzgut (Hide \& AdAMS, 1980; Jellis \& TAYLOR, 1977; Hunger \& MCINTYRE 1979; ERRAMPALLI et al., 2001a), während Bodeninokulum erst durch Verseuchung mit befallenem Pflanzgut entsteht (HUNGER \& MCINTYRE, 1979) und die Ausbreitung des Pilzes im Boden begrenzt ist (FIREMAN \& Allan, 1995; KAMARA \& Huguelet, 1972; MERIDA \& LORIA, 1994b), was in den Bodensuppressivitätstests betätigt wurde. Im Feld erfolgt die Übertragung des Pilzes offenbar sowohl durch aktives Mitwachsen des Pilzes über die Stolonen, als auch durch passiven Wassertransport im Boden. Dabei wird auf Grund der Ergebnisse dieser Arbeit der direkten, aktiven Übertragung über die Stolonen die weitaus größere Bedeutung zugesprochen. Bei der passiven Konidienübertragung fördern Knollen anfälliger Sorten durch noch unbekannte Mechanismen die durch den Boden unterdrückte Konidienkeimung von $H$. solani allerdings wiederum. Nach der Ernte ist der Befall der Tochterknollen relativ gering. Erst im Lager breitet sich der Befall auf den Knollen aus (Peters, 1999) und eine starke Konidienbildung setzt ein (ERrampalli, 2001a). Die Konidien werden über direkten Kontakt der Knollen zueinander oder über Luftbewegungen im Lager übertragen (PETERS, 1999). Die 
Konidien keimen schnell auf den neuen Knollen aus (MARTINEZ, 2004) wobei durch die Ergebnisse dieser Arbeit vermutet wird, dass die Knolle durch einen noch unbekannten Mechanismus die Konidien zur Keimung anregt. Durch Penetration gelangt der Pilz in die Knolle, breitet sich hier intrazellulär weiter aus (MARTINEZ, 2004) und bildet wieder neue Konidien. Eine nekrotrophe Ernährung wird diskutiert, da die betroffenen Kartoffelzellen sowie die umgebenden gesunden Zellen nekrotisieren (MiMS et al., 2000). Im Frühjahr werden diese befallenen Knollen wiederum ausgepflanzt und der Zyklus beginnt von neuem.

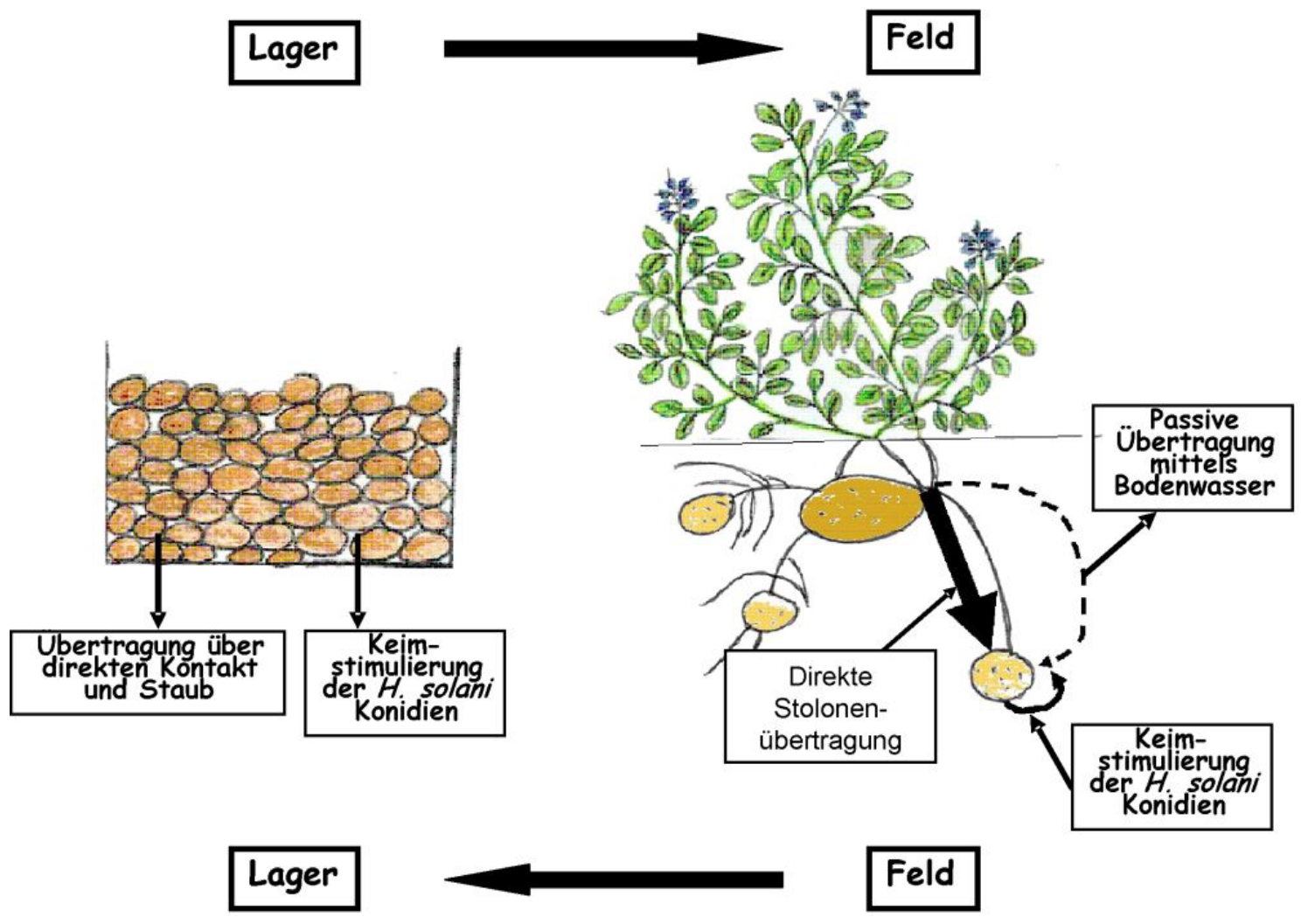

\begin{abstract}
Abbildung 17: Möglicher Lebenszyklus von $H$. solani, dem Erreger des Silberschorfs. Hauptinokulum ist die Mutterknolle, die Übertragung im Boden scheint hauptsächlich aktiv durch Mitwachsendes Pilzes in den Stolonen stattzufinden. Die Passive Übertragung mittels Bodenwasser spielt eine eher untergeordnete Rolle, wobei die Konidien durch Anwesenheit verschiedener Kartoffelsorten stimuliert bzw. die Bodensuppressivität teilweise aufgehoben wird. Im Lager werden die Sporen durch Kontakt und Luftbewegung verteilt, sie keimen schnell aus, unterstützt durch den noch unbekannten Mechanismus der Knolle. Durch direkte Penetration dringt der Pilz in die Knolle ein und breitet sich aus. Im nächsten Jahr werden die Knollen erneut ausgepflanzt und der Zyklus beginnt von neuem.
\end{abstract}

Viele Fragen zur Infektion, Übertragung und Resistenz der Knollen gegenüber dem Pilz sind aber nach wie vor ungeklärt. Es besteht auch in Zukunft noch dringender Forschungsbedarf, zumal es sich um ein nach wie vor hochinteressantes da noch weitestgehend unerforschtes Gebiet handelt. 


\section{Zusammenfassung}

Die Kartoffel zählt neben Getreide zu den zwei wichtigsten Grundnahrungsmittel in Europa. Die Bedeutung der Kartoffelkrankheit Silberschorf, hervorgerufen durch Helminthosporium solani (Dur. et Mont.), hat in den letzten 10 Jahren stark zugenommen. In Extremfällen kann es durch die Krankheit zu Verlusten von bis zu $80 \%$ der geernteten Ware wegen Qualitätsverlust kommen. Die Bekämpfung des Erregers stellt sich als äußerst schwierig dar. Weder pflanzenbauliche Maßnahmen noch der Einsatz von Fungiziden ist aufgrund von Resistenzen des Pilzes gegen die verfügbaren Wirkstoffe erfolgreich. Der vielversprechendste Weg zur Bekämpfung des Silberschorfs ist die Züchtung resistenter Kartoffelsorten.

Erstes Ziel der Doktorarbeit war es, die Anfälligkeit verschiedener Kartoffelsorten auf H. solani zu ermitteln. Dabei sollte der Einfluss äußerer Faktoren wie Klima, Witterung oder Boden berücksichtigt werden. In dieser Arbeit wurde ein Standartsortiment von 12 Kartoffelsorten mit definierter Anfälligkeit erstellt. Es konnten keine resistenten Sorten gefunden werden. Alle Kartoffeln zeigten eine sortenabhängige Anfälligkeit gegen Silberschorf. Die Anfälligkeit variierte von stark anfälligen bis wenig anfälligen Sorten. Dabei hatten äußere Faktoren kaum einen Einfluss. Die Unterschiede in der Anfälligkeit blieben sortenspezifisch an den verschiedenen Standorten, zwischen den verschiedenen Jahren, im Gewächshaus sowie im Lager bestehen.

Zweites Ziel der Arbeit war die Untersuchung der Ursachen der unterschiedlichen Anfälligkeit der Sorten (Resistenzfaktoren). Der in der Literatur beschriebene Zusammenhang zwischen Anfälligkeit und Schalendicke konnte nicht bestätigt werden. Auch die Schalenbeschaffenheit scheint keinen Einfluss $\mathrm{zu}$ haben. Ein weiterer untersuchter Parameter ist der Einfluss phenolischer Substanzen in der Kartoffelschale. Verschiedene Methoden zur Extraktion von Phytoalexinen sowie Ligninen und dessen Vorstufen aus Kartoffelschalen wurden getestet für eine quantitative photometrische Messung und qualitative HPLC-Analysen. Ein Einfluss phenolischer Komponenten auf die Anfälligkeit konnte nicht festgestellt werden. In wieweit dies auf die für Kartoffelschalen möglicherweise ungeeigneten Extraktionsmethoden zurückzuführen ist, ist unklar. 
Weiterhin wurde gezeigt, dass verschiedene Böden eine suppressive Wirkung auf die Keimung der $H$. solani Konidien haben. Es wurde ermittelt, dass bestimmte Kartoffelsorten diese Keimsuppression durch einen noch unbekannten Mechanismus teilweise wieder aufheben können. Die Keiminduktion stand in direkter, signifikanter Beziehung zu den Anfälligkeiten der Sorten. Zur Erforschung der Ursachen wurden Zuckeranalysen durchgeführt. Es konnte keine Beziehung zwischen Zuckergehalt und Keimförderung gefunden werden.

Drittes Ziel der Arbeit war die Erforschung des Übertragungswegs des Pilzes von Mutter- auf Tochterknollen im Boden. Es wurde gezeigt, dass der passive Transport der Konidien im Boden mittels Wasser nur eine untergeordnete Rolle zu spielen scheint. Eine direkte Übertragung des Pilzes durch aktives Mitwachsen in den Stolonen wurde mittels PCR-Analysen nachgewiesen. In Stolonenproben befallener Knollen verschiedener Sorten konnte $H$. solani gefunden werden. Die direkte Übertragung über Stolonen scheint somit nicht nur möglich zu sein, sondern auch eine wichtige Rolle zu spielen. Eine systemische Ausbreitung des Pilzes wurde durch negative Ergebnisse in PCR-Untersuchungen der Leitbündel befallener Knollen ausgeschlossen. 


\section{Summary}

The potato is, together with cereals, one of the two most important stable food in human nutrition because of its precious ingredients. Silver scurf, caused by Helminthosporium solani (Dur. \& Mont.) represents an increasing problem in potato cultivation. In extreme cases, the yield loss because of quality loss can be more then $80 \%$. The control of the disease is exceedingly difficult. Neither plant cultivating arrangements nor adequate fungicide because of resistances of the fungus are available. The most promising solution is the breeding of resistant potato cultivars.

The first aim of this project was to work out the susceptibilities of different potato cultivars against silver scurf. The influence of outer factors like weather or soil conditions should be considered. In this work a standard assortment of potato with a defined susceptibility could be established. No resistant genotype was found. The susceptibility varied from very susceptible to slightly susceptible cultivars. Outer factor hardly showed any effect and could be excluded to the greatest possible extent. The differences in susceptibility of the cultivars were analogue in different location, during several years, in greenhouse and during storage.

The second aim was the detection of the causes of the differences in susceptibility (resistance factors). A relation between peel thickness and susceptibility could not be approved. As well the peel consistency seems to have no influence. Another investigated parameter was the amount of phenolic compounds within the potato peel. Several methods for extraction of phytoalexines and Lignin with its pre-stages in potato peel where proved for a quantitative photometric measurement and qualitative test via HPLC analyses. A influence of phenolic compounds on the susceptibility of the cultivars could no be examined. It is unclear how far these results are dependent on the unsuitable extraction methods for potato peels.

It was also found, that different soils had a suppressive impact on the germination of the $H$. solani conidias. Furthermore it was discovered, that several potato cultivars can somehow increase the amount of germinated conidias again. This germination induction was closely related to the susceptibility of the cultivars. To investigate the causes, sugar analyses were carried out. There was no relation between sugar amount and germination induction. 
The third aim was the investigation of the devolution of the fungus from mother to daughter tubers in soil. It was shown that the transportation through soil just plays a secondary role in conidia devolution. A direct devolution through stolones was examined via PCR trials. In stolone samples $H$. solani was detected. This leads to the conclusion that direct devolution is not only possible but also plays an important role. A systemical devolution was excluded with negative results of PCR trials of the vascular bundle of infected tubers. 
Adams, A.P.; Sandar, N.; Nelson, D.C. (1970): Some properties of soils affecting russet scab and silver scurf of potatoes. American Potato Journal 47:49-57

AGRIOS, G.N. (1978): How plants defend themselves against pathogens. In: "Plant Pathology"; G.N. Agrios (eds.), Academic Press. Inc. FL., 72-85

AKAI, S. (1959): Histology of defence in plants. In: "Plant Pathology"; J.G. Horsfall; A.E. Dimond (eds.), Academic Press. NY; 1:391-434

AKAI, S.; OUCHI, S. (1971): Morphological and biochemical events in plant - parasite interaction. The Phytopathol. Soc. of Japan, Tokyo

ARTSCHWAGER, E. (1927): Wound periderm formation in the potato as affected by temperature and humidity. J. Agric. Res. 35(11):995-1000

Bains, P.S.; Bisht, V.S.; BenaRd, D.A. (1996): Soil survival and thiobendazole sensitivity of Helminthosporium solani isolates from Alberta, Canada. Potato Research 36:76

Bamberg, J.B.; Martin, M.W.; Schartner, J.J. (1994): Elite selections of tuberbearing Solanum species germplasm. Inter-Regional Potato Introduction Station, NRSP-6. Sturgeon Bay, WI

BARnetT, H.L.; Hunter, B.B. (1998): Helminthosporium. In: "Illustrated Genera of Imperfect Fungi"; H.L. Barnett; B.B. Hunter (eds.); $4^{\text {th }}$ edn. St Paul, Minnesota, American Phytopathological Society Press 124-125

Basha, S.A.; Mishra, R.K.; JHA, R.N.; PANDEY, V.B.; Singh, U.P. (2002): Effect of berberine and (+/-)-bicuculline isolated from Corydalis chaerophylla on spore germination of some fungi. Folia Microbiol. (Praha) 47(2):161-165 
BATEMAN, D.F. (1967): Alternation of cell wall components during pathogenesis by Rhizoctonia solani. In: "The Dynamic Role of Molecular Constituents in Plant Parasite Interaction"; C.J. Mirocha; B. I. Uritani (eds.); St. Paul, Minnesota, American Phytopathological Society Press 58-75

Bell, J.N.; DiXon, R.A.; BaIley，J.A.; RoWell，P.M.; LAMP，C.J. (1984): Differential induction of chalcone synthase mRNA activity at the onset of phytoalexin accumulation in compatible and incompatible plant pathogen interactions. Proc. Natl. Acad. Sci. USA 81:3384-3388

Bernard, M.A.; Flemming, W.D.; Llewellyn, D.B.; Priefer, R.; Xiaolong, Y.; Sabatino, A.; Plourde, G.L. (1999): Biochemical characterization of the suberization-associated anionic peroxidase of potato. Plant Physiology 121:135-145

BöNER, H. (1997): Pflanzenkrankheiten und Pflanzenschutz. UTB für Wissenschaft; Ulner GmbH \& Co., Stuttgart

Burgess, J.G.; Jordan, E.M.; Bregu, M.; Mearns-SpragG, A.; Boyd, K.G. (1999): Microbial antagonism: a neglected avenue of natural products research. J. Biotechnol. 70:27-32

BURKE, O.D. (1938): The silver scurf disease of potatoes. Bulletin of Cornell University Agricultural Experimental Station 692:1-30

BUShNELL, W.R.; BERgQuist S.E. (1975): Aggregation of host cytoplasm and the formation of papillae and haustoria in powdery mildew of barley. Phytopathology 65:310-318

Carnegie, S.F.; Choiseul, J.W.; Roberts, A.M.I. (2003): Detection of Colletotrichum coccodes and Helminthosporium solani in soils by bioassay. Plant Pathology 52(2):13-21 
Carter, M.R.; Kunelius, H.T.; Sanderson, J.B.; Kimpinski, J.; Platt, H.W.; BOLINDER, M.A. (2003): Productivity parameters and soil health dynamics under long - term 2 - year potato rotations in Atlantic Canada. Soil and Tillage Research 72(2):153-168

Chilvers K.F., Reed R.H., Perry J.D. (1999): Phototoxicity of rose bengal in mycological media-implications for laboratory practice. Lett. Appl. Microbiol. 28(2):103-7

Clark, G. (1973): Staining procedure used by the biological stain commission. Published for the biological stain commission. The Williams \& Willkins Co., Baltimore

Clarkson, D. (1974): Ion Transport and Cell Structure in Plants. Halsted Press, John Wiley and Sons, NY

Coleman, I.W.; Hodges, C.F. (1990): Growth and conidiation of Bipolaris sorokiniana in response to methionine and ethylene. Mycol. Res. 94:1013-1016

Cottle, W.; Kolattukudy, P.E. (1982): Biosynthesis, deposition, and partial characterization of potato suberin phenolics. Plant Physiol. 69:393-399

Coxon, D.T.; Price, K.R.; Howaed, B.; Osman, S.F.; Kalan E.B.; ZaCharias, R.M. (1974): Two new vestipirone derivatives: stress metabolites from potato (Solanum tuberosum) tubers. Tetrahedron Lett. 34:2921-2924

De Boer, W.; Verheggen, P.; Klein Gunnewiek P.J.A.; KowalchuK G.A.; VAN VEEN; J.A. (2003): Microbial community composition affects soil fungistasis. Appl. Environ. Microbiol. 69(2):835-844

Denner, F.D.N.; Millard, C.; Geldenhuys, A.; Wehner, F.C. (1997): Treatment of seed potatoes with prochloraz for simultaneous control of silver scurf and black dot on progeny tubers. Potato Research 40:221-227 
Deverall, B.J. (1977): Defence Mechanisms of Plants. Cambridge Univ. Press, Cambridge

DiCKSON, B.T. (1926): The black dot disease of potato. Phytopathology 16:23-40

Elson, M.K.; SChISLER, D.A.; JACKSON, M.A. (1998): Carbon - to nitrogen ratio, carbon concentration, and amino acid composition of growth media influence conidiation of Helminthosporium solani. Mycologia 90(3):406-413

ERrampalli, D.; SAUnders J.M.; Holley J.D. (2001a): Emergence of silver scurf (Helminthosporium solani) as an economically important disease of potato. Plant Pathology 50:141-153

Errampalli, D.; Saunders, J.; Cullen, D. (2001b): A PCR-based method for detection of potato pathogen, Helminthosporium solani, in silver scurf tuber tissue and soils. J. Microbiol. Methods 44(1):59-68

ESAU, K. (1977): Anatomy of Seed Plants. $2^{\text {nd }}$ Edition; John Wiley and Sons. New York

Evans, R.C.; BLACK, C.I. (1981): Interaction between nitrogen sources and xylose affecting growth, conidiation, and polyphenoloxidase activity in Bipolaris maydis race T. Can. J. Bot. 59:2102-2107

FARKAS, G.L.; KIRÁLY, Z. (1962): Role of phenolic compounds in the physiology of plant disease and disease resistance. Phytopatol. Z. 44:105-150

FaIze, M.; FaIZe, L.; KoIKe, N. ; IshIZAKA, M. ; ISHII, H. (2004): Acibenzolar-smethyl-induced resistance to japanese scrab is associated with potentiation of multiple defence responses. Phytopathology 94:604-612

Fireman, D.M.; Allen, E.J. (1995): Transmission of Helminthosporium solani from potato seed tubers and effects of soil conditions, seed inoculum and seed physiology on silver scurf disease. J. of Agric. Science, Cambridge 124:219-234 
FraZier, M.J.; ShetTY, K.K.; KLeINKOPF, G.E.; Nolte, P. (1998): Management of Silver Scurf (Helminthosporium solani) with fungicide seed treatments and storage practices. Amer. J. of Potato Res. 75:129-135

FRIEND, J. (1981): Plant phenolics, lignification and plant disease. Progr. Phytochem. 7:197

FRY, S.C. (1982): Phenolic components of the primary cell wall. Biochem. J. 203:493504

FuChS, G.; Wretling, S. (1979): Bestämning av fruktos glukos och sackaros i livsmedel. Vår Föda 31:435-439

Gans, P.T.; Vaughan, J.E.; ThOMas, J.E. (2002): The evaluation of potato cultivar resistance to fungal diseases causing tuber blemishes. In: "Crop Protection in Northern Britain”; Farnham, Surrey, UK; British Crop Protection Council, 263268

GrifFITHS, D.W.; DALE, M.F.B.; BAIN, H. (1994): The effect of cultivar, maturity and storage on photo - induced changes in the total glycolakaloid and chlorophyll contents of potatoes (Solanum tuberosum). Plant Science 98:103-109

GriSEBACH, H. (1981): Lignins. In: „The biochemistry of plants.“; Vol. 7 P.K. Stumpf; E.E. Conn. (eds.); Academic press, NY, 457-478

Gross, D. (1993): Phytoalexins of the brassicaceae. Zeitschr. f. Pflanzenkrankh. Und Pflanzenschutz 100(4):433-442

Groth, R.W.; WeBb, R.E. (1983): Maintenance and growth of Helminthosporium solani. American Potato Journal 60:281-287 
HALl, S.M.; Hide, G.A. (1994): The control of silverscurf and development of thiabendazole resistance in Helmithosporium solani as affected by the rate of fungicide applied to potato seed tubers. Potato Res. 37:403-411

HALL S.M. (1996): Sources of Helminthosporium solani inoculum during the potato crop cycle and its importance in contaminating healthy tubers. Abstract of the $13^{\text {th }}$ Triennial conference of the European Association for Potato Research, 1996. Wageningen, The Netherlands: European Association for Potato Research 234-235

Halverson, L.J.; STACEY, G. (1986): Signal exchange in plant-microbe interactions. Microbiol. Reviews 50(2):193-225

Hambloch, C.; Menth, H. (2003): ZMP-Bilanz Kartoffeln 2003. ZMP Zentrale Markt- und Preisberichtstelle, Bonn

HAMmerschmidT, R.; LAMPORT, D.T.A.; Muldoon, E.P. (1984): Cell wall hydroxyproline enhancement and lignin deposition as an early event in the resistance of cucumber to Cladosporium cucumerinum. Physiol. Plant Pathol. 24:43-47

HAMmerschmidt (1999): Phytoalexins: What have we learned after 60 years? Ann. Rew. Phytopathol. 37:285-306

HaRdhaM, A.R.; Mitchell, H.J. (1998): Use of molecular cytology to study the structure and biology of phytopathogenic and mycorrhizal fungi. Fungal Genetics and Biology 24:252-284

HARDING, H. (1975): Effects of d-amino acids on conidium size and numbers of pseudosepta per conidium in isolates of Bipolaris sorikiniana. Can. J. Bot. 53:600-603 
Hardy, C.E.; Burgess, P.J.; Pringle, R.T. (1997): The effect of condensation on the sporulation of Helminthosporium solani on potato tubers infected with silver scurf and held in simulated store conditions. Potato Research 40:169-180

HART, H. (1989): Organische Chemie. VCH Verlagsgesellschaft mbH, Weinheim

HARTLEY, R.D. (1987): HPLC for the separation and determination of phenolic compounds in plant cell walls. In: "High performance liquid chromatography in plant sciences"; H.F. Linskens; J.F. Jackson (eds.), Springer Verlag, 92-101

HeINY D.K.; MCINTYRE A. (1983): Helminthosporium solani dur.\& mont. development on potato periderm. American Potato Journal 60:773-789

HervieuX, V.; Yaganza, E.S.; Arul, J.; Tweddell, R.J. (2002) : Effects of organic and inorganic salts on the development of Helminthosporium solani, the causal agent of potato silver scurf. Plant Diseases 86:1014-1018

HIDE, G.A.; HIRST, J.M.; GRIFFITH, R.L. (1969): Control of potato tuber diseases with systemic fungizides. In: Proceedings of the Fifth British Insecticide and Fungicide Conference, Brigjton. Croydon, UK: British Crop Protection Council, 310-314

Hide, G.A.; AdAMs, M.J. (1980): Relationship between disease levels on seed tubers, on crops during growth and in stored potatoes. 3. silver scurf. Potato Res. 23:229-240

HIDE, G.A. (1987): Effects of irrigation and tuber size on yield and infection of potatoes from commercial and healthier seed stocks. Potato Research 30:637-649

Hide, G.A.; HALL, S.M.; BoORER, K.J. (1988): Resistance to thiabendazole in isolates of Helminthosporium solani, the cause of silver scurf disease of potatoes. Plant Pathology 37:377-380 
Hide, G.A.; Hall, S.M. (1993): Development of resistance to thiabendazole in Helminthosporium solani (silver scurf) as a result of potato seed tuber treatment. Plant Pathol. 42:707-714

HiguCHI, T. (1985): Degradative pathways of lignin model compounds. In: "Biosynthesis and biodegradation of wood components."; T. Higuchi (eds.) 557578

Hilton, J.A.; Stewart, H.E.; Linton, S.L.; Nicolson, M.J.; Lees, A.K. (2000): Testing the resistance to silver scurf in commercial potato cultivars under controlled environmental conditions. Potato Research 43(3):263-271

Ho, W.C.; Ko, W.H. (1986): Microbiostasis by nutrient deficiency shown in natural and synthetic soils. J. Gen. Microbiol. 132:2807-2815

HoOKer, W.J. (1981): Compendium of potato diseases. Amer. Phytopath. Society Press, St Paul, MN

Hunger, R. M.; MCInTyRe, A. (1979): Occurrence, development, and losses associated with silver scurf and black dot on Colorado potatoes. American Potato Journal 56:289-306

JANSKY, S.H. (2000): Breeding for disease resistance in potato. Plant Breed. Rev. 19:69-155

JANSKY, S.H.; RouSE, D.I. (2003): Multiple disease resistance in interspecific hybrids of potato. Plant Disease 87:266-272

JELlis, G.T.; TAYLOR, G.S. (1974): The relative importance of silver scurf and black dot: two disfiguring diseases of potato tubers. ADAS Quaterly Review 14:53-63

Jellis, G.T.; TAYLOR, G.S. (1977): The development of silver scurf (Helminthosporium solani) disease of potato. Annals of Applied Biology 86:1928 
JohAnSEn, D.A. (1940): Plant Micotechnique. McGraw-Hill Book Co.; Inc., NY 523ff.

Kamara, A.M.; Huguelet, J.E. (1972): Host range and overwintering of Helminthosporium solani. (Abstr.) American Potato Journal 49:365

KaWChuCK, L.M.; Holley, J.D.; LYNCH, D.R.; CleaR, R.M. (1994): Resistance to thiabendazole and thiophanate-methyl in Canadian isolates of Fusarium sambucinum and Helminthosporium solani. American Potato Journal 71:185192

Kicinski, H.G.; Kettrup, A.; Boos, K.S.; Masuch, G. (1988): Single and combined effects of continous and discontinous $\mathrm{O}_{3}$ and $\mathrm{SO}_{2}$ immission on Norway Spruce needles. Intern. J. Environ. Anal. Chem. 32:213-241

KolatTUKUDY, P.E. (1981): Structure, biosynthesis, and biodegradation of cutin and suberin. Annu. Rev. Plant Physiol. 32:539-567

KoOpManN, B. (2004): persönliche Mitteilung

KUĆ, J. (1973): Metabolites accumulating in potato tubers following infection and stress. Teratology 8:333-338

KUĆ, J. (1995): Systemic induced resistance. Asp. Appl. Biol. 42:235-242

LANGERFELD, E. (1985): Silberschorf an Kartoffelknollen. Der Kartoffelbau 30(11): 414-115

LEACH, S.S.; MurdoCh, C.W.; Gordon, C. (1991): Response of selected soilborne fungi and bacteria to herbicides utilized in potato crop management systems in Maine. American Potato Journal 68:269-278

Lees, A.K.; Hilton, A.J. (2003): Black dot (Colletotrichum coccodes): an increasingly important disease of potato. Plant Pathology 52:3-12 
LENNARD, J. H. (1980): Factors affecting the development of silver scurf (Helminthosporium solani) on potato tubers. Plant Pathology 29:87-92

LedinghaM, P.J.; CHINn, S.H.F. (1955): A flotation method for obtaining spores of Helminthosporium sativum from soil. Can. J. Bot. 33:298-303

LIEBMAN, J.A.; EPSTEIN, L. (1992): Activity of fungistatic compounds from soil. Phytopathology 82:147-153

LOCKWOOD, J. L. (1977): Fungistasis in soils. Biol. Rev. 52:1-43

LU, F: RALPH, J. (1997a): Derivatization followed by reductive cleavage (DFRC method), a new method for lignin analysis: protocol for analysis of DFRC monomers. J. Agric. Food Chem. 45:2590-2592

LU, F: RALPH, J. (1997b): The DFRC method for lignin analysis. Part 1. A new method for $\beta-$ aryl ether cleavage: lignin model studies. J. Agric. Food Chem. 45:4655-4660

LU, F: RALPH, J. (1998): The DFRC method for lignin analysis. Part 2. Monomers from isolated lignins. J. Agric. Food Chem. 46:547-552

MARTIN, J.T. (1964): Role of cuticle in the defence against plant disease. Ann. Rev. Phytopathol. 2:81-100

Martinez, C.; RiouX, D.; Tweddell, R.J. (2004): Ultrastructure of the infection process of potato tuber by Helminthosporium solani, causal agent of potato silver scurf. Mycol. Research 108:828-836

Maurya, S.; Srivastava, J.S.; Jha, R.N.; Pandey, V.B.; Singh, U.P. (2002): Efficacy of alkaloid (-)-corypalmine against germination of some fungi. Folia Microbiol. (Praha) 47(3):287-290 
Melhus, I.E. (1913): Silver scurf a disease of the potato. Bureau of Plant Industry Circ. No. 127:15-24

Menden, B. (1995): Biochemische Analysen zur Bedeutung von Phenolsäuren und Lignin für Resistenz und Anfälligkeit von Weizenpflanzen gegen Schwarzrost (Puccinia graminis f. sp. tritici) Dissertation an der Rheinisch - Westfälischen Technischen Hochschule Aachen

MeridA, C. L.; LoRIA, R. (1994a): Comparison of thiabendazole-sensitive andresistant Helminthosporium solani isolates from New York. Plant Disease 78:187-192

MeridA, C. L.; LORIA, R. (1994b): Survival of Helminthosporium solani in soil and invitro colonization of senescent plant tissues. Am. Potato J. 71:591-598

MERIDA, C. L.; LORIA, R.; HALSETH, D.E. (1994): Effects of potato cultivar and time of harvest on the severity of silver scurf. Plant Disease 78(2):146-149

Metlitskit, D.B.; Ozeretskowskaya, O.C.; Vulfson, N.S.; Chalova, C.J. (1979): Effects of lubimin on potato resistance to Phytophtora infestans and its chemical identification. Mikologya I fitopatologya 5:439-443

Michaud, M.; Martinez C.; Simao-Beaunoir A.M.; Belanger R.R.; TWeddell R.J. (2002): Selection of antagonist microorganisms against Helminthosporium solani, causal agent of potato silver scurf. Plant Disease. 86(7):717-720

Mims, C.W. (1991): Using electron microscopy to study plant pathogenic fungi. Mycologia 83:1-19

Mims, C.W.; Copes, W.E.; RiChardson, E.A. (2000): Ultrastructure of the penetration and infection of pansy roots by Thielaviopsis basicola. Phytopathology 90:843-850 
Moerschbacher, B.M.; NOLL, U.; FlotT, B.E.; Reisener, H.J. (1988): Lignin biosynthetic enzymes in stem rust infected, resistant and susceptible near isogenic wheat lines. Physiol. Mol. Plant Pathol. 33:33-46

MOERSCHBACHER, B.M. (1989): Lignin biosynthesis in stem rust infected wheat. ACS Symp. Ser. 399:370-382

MoOI, J.C. (1968): The silver scurf disease of potato. Mededeling van het Instituute voor Plantenzeiktenkundig Onderzoek 482:1-62

Mortimer, C.E. (1987): Chemie, Das Basiswissen der Chemie. 5, Auflage, Georg Thieme Verlag, Stuttgart, NY

MulLER, K.O. (1959): Hypersensitivity. In: "Plant Pathology"; J.G. Horsfall; A.E. Dimond (eds.), Academic Press. NY; 1:469-519

NEMEC, S. (1971): Mode of entry of Pythium perniciosum into strawberry roots. Phytopathology 61:711-714

Nicholson, R.L.; HAMmerschmidt, R. (1992): Phenolic compounds and their role in disease resistance. Ann. Rev. Phytopathol. 70:369-389

Olivier, C.; LORIA, R. (1998): Detection of Helminthosporium solani from soil and plant tissue with species-specific PCR-primers. FEMS Microbiology Letters 168:235-241

ORTIZ, R. (1998): Potato breeding via ploidy manipulations. Plant Breed. Rev. 16:1586

PenG, J; LU, F.; RALPH, J. (1998): The DFRC method for lignin analysis. 4. Lignin dimers isolated from DFRC-degraded pine wood. J. Agric. Food Chem. 46(2):553-560 
Percival, G.C.; KaRiM, M.S.; Dixson, G.R. (1998): Light induced bio-control of potato storage pathogens in vitro. 41:143-153

Peters, R.D.; Sturz, A.V.; Carter, M.R.; SAnderson, J.B. (2003): Developing disease-suppressive soils through crop rotation and tillage management practices. Soil and Tillage Research 72(2):181-192

Peters, R. (1999): Einfluss des Erntetermins und der Lagerung auf den Silberschorfbefall. Mitt. der Dt. Phytomedizin. Gesellschaft 29(2):27

PiCKNEY, L. (2002): persönliche Mitteilung

Putz, B. (1998): Kartoffeln: Züchtung, Anbau, Verwertung. Behr's Verlag Hamburg

RAdTKe, W.; RieckmanN, W; Brendler, F. (2000): Kartoffel - Krankheiten, Schädlinge, Unkräuter. Verlag Th. Mann, Gelsenkirchen-Buer

RAMSEY, G.E. (1917): Formation of cork layer on potato tuber following infection with Rhizoctonia. J. Agr. Res. 9:421-426

READ, P. J. (1991): The susceptibility of tubers of potato cultivars to black dot (Colletotrichum coccodes (Wallr.) Hughes). Annals of Applied Biology 119:475-482

READ, P. J.; HIDE, G. A. (1984): Effects of silver scurf (Helminthosporium solani) on seed potatoes. Potato Research 27:145-154

RIDE, J.A. (1980): The effect of induced lignification on the resistance of wheat cell walls to fungal degradation. Physiol. Mol. Plant Path. 16:187-196

RIDE, J.P.; PEarCe, R.B. (1979): Lignification and papilla formation at sides of attempted penetration of wheat leaves by non-pathogenic fungi. Physiol. Mol. Plant Path. 15:79-92 
Rodriguez, D. A.; Secor, G. A.; Gudmestad, N. C.; Grafton, K. (1995): Screening tuber-bearing Solanum species for resistance to Helminthosporium solani. American Potato Journal 72:669-679

RODRIGUEZ, D.A. (1995): Studies on epidemiology and management of silver scurf of potato. Ph.D. diss. North Dakota State University, Fargo

Rodriguez, D. A.; Secor, G. A.; Gudmestad, N. C.; Francl, L.J. (1996): Sporulation of Helminthosporium solani and infection of potato tubers in seed and commercial Storage. Plant Disease 80(9):1063-1070

Rohringer, R.; KIM, W. K.: SAMbORSKI, D. J.; HoWeS, N. K. (1977): Calcofluor: An optical brightener for fluorescence microscopy of fungal plant parasites in leaves. Phytopathology 67:808 - 810

Ryals, J.A.; Neuenschwander, K.H.; Willits, M.G.; Molina, A.; Steiner, H.Y.; HunT, M.D. (1996): Systemic acquired resistance. Plant Cell 8:1809-1819

SAKaI, S.; Doke, N.; TomiYAMA, K. (1979): Relation between necrosis and rishitin accumulation in potato tuber slices treated with hyphal wall components of Phytophtora infestans. Ann. Phytopath. Soc. Japan 48:238-240

SANDER, J.F. (1995): Biochemisch-ohysiologisch Ursachen der durch die Stickstoffernährung modifizierten Anfälligkeit des Wiezens (Triticum aestivum L.) gegenüber dem echten Mehltau (Erysphe graminis DC f. sp. tritici Marchal). Dissertation an der Georg August Universität, Göttingen

SARKANEN, K.V.; LUDWIG, C.H. (1971): Lignins, occurence, formation, structure and reactions. Wiley, NY

SaUnders, J.M.; ERRAMPalli D. (2001): Comparison of methods to detect resistance of Helminthosporium solani to a thiabendazole fungicide. Phytoprotection 82(3):103-112 
SCHEID, L. (2000): Silberschorf - weit mehr als nur ein Schönheitsfehler! Kartoffelbau 51(5):198-200

SCHULTZ, E. (1916): Silver scurf of the Irish potato caused by Spondylocladium atrovirens. J. Agric. Res. 6:339-350

SCHWAERZEL, R. (2003): Veränderte Vermarktungspraxis fördert den Silberschorf der Kartoffeln und beunruhigt die Forscher der RAC. Pressemitteilung der eidgenössischen Forschungsanstalt für Pflanzenbau in Changins http://www.blw.admin.ch/aktuell/medien/d/0305222.pdf

SECOR, G.A. (1993): Silver scurf becoming a major problem of cosmetics. Valley Potato Grower 58:16-18

SECOR, G.A. (1994): Management strategies for fungal diseases of tubers. In: “Advances in Potato Pest Biology and Management." G.W. Zhender; M.L. Powelson; R.K. Jansson; K.V. Raman (eds.); St Paul, USA: American Phytopathol. Society Press, 155-157

Simmons, S.A.; Shoemaker, R.A. (1952): Differential staining of fungus and host cells using a modification of Pianese IIIb. Stain Technol. 27:121

SINGH, A. (1972): A selective antibiotic medium for isolation of Helminthosporium solani from soil. Indian Journal of Mycology and Plant Pathology 2:160-164

Sobolev, V.S. (2001): Vanillin content in boiled peanuts. J. Agric. Food Chem. 49(8): $3725-3727$

Soliday, C.L.; Kolattukudy, P.E.; Davis, R.W. (1979): Chemical and ultrastructural evidence that waxes associated with the suberin polymer constitute the major diffusion barrier to water vapor in potato tuber (Solanum tuberosum). Planta 146:607-614 
Southerton, S.G.; Deverall, B.J. (1990a): Histochemical and chemical evidence for lignin accumulation during the expression of resistance to leaf rust fungi in wheat. Physiol. Mol. Plantpath. 36:483-494

Southerton, S.G.; Deverall, B.J. (1990b): Changes in phenolic acids in wheat leaves expressing resistance to Puccinia recondite f. sp. tritici. Physiol. Mol. Plant Path. 37:437-450

Southerton, S.G.; Deverall, B.J. (1990c): Changes in phenylalanine ammonialyase and peroxidase activities in wheat cultivars expressing resistance to leafrust fungus. Physiol. Mol. Plant Pathol. 39:223-230

Stachewicz, H.; Schumann, G.; Peters, R.; KäPPeler, L. (2001): Prüfung der Silberschorfanfälligkeit. Kartoffelbau 52(1/2):13-17

STECK, U.; Zellner, M. (2002): Integrierter Pflanzenschutz Kartoffelkrankheiten. Mitteilung der Bayrischen Landesanstalt für Bodenkultur und Pflanzenbau. Herausgeber: LPB Freising

Stevenson, C.L.; Loria, R.; Franc， D.G.; Weingartner, D.P. (2001): Compendium of Potato Diseases. $2^{\text {nd }}$ edn. Americ. Phytopath. Society Press, St. Paul, MN

Stone, J.E.; BLUndell, M.J. (1951): Rapid micromethod for alkaline nitrobenzene oxidation of lignin and determination of aldehydes. Anal. Chem. 23:771-774

Sun, R.C.; Sun, X.F.; ZhANG, S.H. (2001): Quantitative determination of hydroxycinnamic acids in wheat, rice, rye, and barley straws, maize stems, oil palm frond fiber, and fast-growing poplar wood. J. Agric. Food Chem. 49(11):5122-5129

TARChEVSKy, I.A. (2002): Pathogen-induced plant proteins (review). App. Biochem. And Microbiol. 37(5):441-455 
TоміYамA, K. (1956): Cell physiological studies on the resistance of potato plants to Phytophtora infestans. IV. On the movements of cytoplasm of the host cell induced by the invasion of Phytophtora infestans. Annals of the Phytopathological Society Japan 21:54-62

TomiYaMa, K.; SAKUma, T.; Ishizaka, N.; SATO, N.; KATSUi, N.; TaKasugi, M.; Masanume, T. (1968): A new antifungal substance isolated from resistance tuber tissue infected by pathogens. Phytopathology 58:115-116

Tsror, L.; Peretz, A.I. (2002): Reduction of silver scurf on potatoes by pre-and poststorage treatment of seed tubers with imazalil. Amer. J. of Potato Research 79(1):33-37

Trautner, K. (1969): Enzymatische Zuckerbestimmung. Zeitschrift für Ernährungswissenschaft 8:40-45

VARnS, J.L.; KuĆ, J.; WilliamS, E.B. (1971): Terpenoid accumulation as a biochemical response of the potato tuber to Phytophtora infestans. Phytopathology 61:174-177

White, T.J.; Bruns, T.; Lee, S.; TAYlOR, J. (1990): Amplification and direct sequencing of fungal ribosomal RNA genes for phylogenetics. In: "PCR Protocols: A Guide to Methods and Applications"; M.A. Innis; D.H. Gelfand; J.J. Sninsky; T.J. White (eds.); Academic Press, San Diego, CA. 315-322

Xu, H; Mendgen, K. (1991): Early events in living epidermal cells of cowpea and broad bean during infection with basidiospores of the cowpea rust fungus. Canadian Journal of Botany 69:2279-2285 


\section{Danksagung}

Ich möchte mich ganz herzlich bei Herrn Prof. von Tiedemann für die Betreuung dieser Doktorarbeit und die in jeder Hinsicht gewährte Freiheit und Unterstützung beim Forschen bedanken. Herrn Prof. Karlovsky danke ich dabei auch herzlich für die Übernahme des Korreferates.

Besonderer Dank gilt Herrn Birger Koopmann, der bei allen Problemen immer ein offenes Ohr hatte und immer auch einen sehr guten Rat wusste. In diesem Zusammenhang möchte ich auch Frau Evelin Vorbeck, Frau Dagmar Tacke und Frau Cornelia Hühne für die ständige Hilfsbereitschaft und Unterstützung meinen Dank sagen. Außerdem möchte ich mich ganz herzlich bei Frau Maack, Frau Bode und dem ganzen Sekretariat für die ständige große Hilfe bei allen administrativen Problemen bedanken. Durch Sie wurde oft das Unmögliche plötzlich ohne Probleme möglich.

Des Weiteren bedanke ich mich bei allen Zugehörigen der Abteilungen allgemeine Pflanzenpathologie, Virologie und molekulare Pflanzenpathologie für die schöne Atmosphäre und Hilfsbereitschaft während der drei Jahre am Institut.

Ein besonderer Dank gilt den deutschen Kartoffel-Züchterhäusern, die mir diese Arbeit finanziell ermöglicht haben. Besonders zu erwähnen sind dabei Norika, Saka-Ragis und Böhm Nordkartoffel GmbH für die Bereitstellung und Betreuung der Feldversuche. Ganz besonders möchte ich mich nochmals bei Herrn Dr. Holger Junghans und der Norika für die Übernahme meines Arbeitsplatzes bedanken.

Danken möchte ich auch dem Bundessortenamt Hannover für die Bereitstellung unabhängiger Knollenproben sowie der KtBL, Dethlingen für die Unterstützung bei den Feldversuchen.

Zum Schluss möchte ich mich noch herzlich bei meinen Eltern, meiner Familie sowie meinen Freunden bedanken, die immer für mich da waren und mir in schwierigen Zeiten zur Seite gestanden haben. 


\section{Lebenslauf}

Name:

Geboren:

Eltern:

1982-1986

1986-1995

1995

1995-1997

1997

1997-2001

Juni 2000-April 2001

April 2001

Mai 2001-Februar 2002

März 2002 - Mai 2005
Lili Hofmann

17.12.1975 in Den Haag/Holland

Götz Hofmann, Rechtsanwalt; Christa Hofmann, Ärztin

Besuch der Grundschule „Ostschule“ in Neustadt an der Weinstrasse

Besuch des altsprachlichen Kurfürst-Ruprecht Gymnasiums in Neustadt an der Weinstrasse

Abitur am Kurfürst-Ruprecht Gymnasium in Neustadt an der Weinstrasse

Grundstudium der Biologie an der Phillips-Universität Marburg

Vordiplom der Biologie an der Phillips-Universität Marburg

Hauptstudium der Biologie an der Georg-AugustUniversität Göttingen

Diplomarbeit über das Thema: "Untersuchungen $\mathrm{zu}$ den RPS26 - Genen in Saccharomyces cerevisiae"

Diplom im Fach Biologie mit Fächerkombination: Mikrobiologie, Humangenetik, Jura

(rschiedene Arbeiten als wissenschaftliche Hilfskraft am Institut für Pflanzenpathologie und Pflanzenschutz der Universität Göttingen sowie Auslandsaufenthalt in Granada/Spanien zum Erlernen der spanischen Sprache

Dissertation am Institut für Pflanzenpathologie und Pflanzenschutz der Universität Göttingen über das Thema: „Untersuchungen zur Resistenz von Kartoffeln gegenüber Helminthosporium solani, dem Erreger des Silberschorfs, sowie dessen Übertragung von Mutter- auf Tochterknollen“" 